\title{
Archaeological Investigations at a Spanish Colonial Site, (41KA26-B) Karnes County, Texas
}

Cynthia L. Tennis

Follow this and additional works at: https://scholarworks.sfasu.edu/ita

Part of the American Material Culture Commons, Archaeological Anthropology Commons, Environmental Studies Commons, Other American Studies Commons, Other Arts and Humanities Commons, Other History of Art, Architecture, and Archaeology Commons, and the United States History Commons

Tell us how this article helped you.

This Article is brought to you for free and open access by the Center for Regional Heritage Research at SFA ScholarWorks. It has been accepted for inclusion in Index of Texas Archaeology: Open Access Gray Literature from the Lone Star State by an authorized editor of SFA ScholarWorks. For more information, please contact cdsscholarworks@sfasu.edu. 


\section{Archaeological Investigations at a Spanish Colonial Site, (41KA26-B) Karnes County, Texas}

\section{Licensing Statement}

This is a work produced for the Texas Department of Transportation (TxDOT) by the report producer. TxDOT and the report producer jointly own all rights, title, and interest in and to all intellectual property developed under TXDOT's contract with the report producer. The report may be cited and brief passages from this publication may be reproduced without permission provided that credit is given to both TXDOT and the report producer. Permission to reprint an entire chapter, section, figures or tables must be obtained in advance from either the Supervisor of the Archeological Studies Branch, Environmental Affairs Division, Texas Department of Transportation, 125 East 11th Street, Austin, Texas, 78701 or from the report producer. 
Archaeological Investigations at a Spanish Cölonial Site, (41KA26-B)

Karnes County, Texas

\section{by Cynthia L. Tennis}

Contributions by

I. Waynne Cox, Owen Ford, Anne A. Fox, Timothy K. Perttula, and Steve A. Tomka, with Elizabeth J. Reitz and Barnet Pavao-Zuckerman

Appendices by

Hector Neff and Michael D. Glascock, and David V. Hill

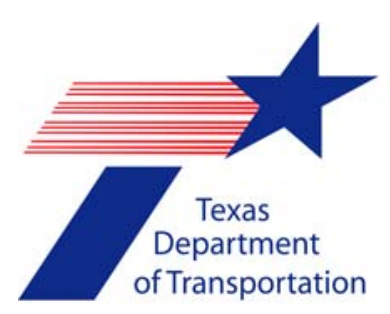

Environmental Affairs Division

Archeological Studies Program, Report No. 26

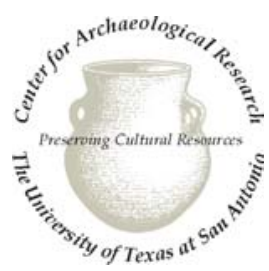

Center for Archaeological Research The University of Texas at San Antonio Archaeological Survey Report, No. 302

February 2001 


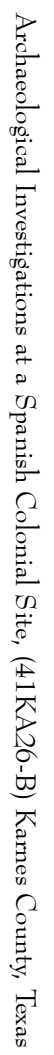

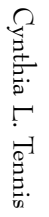

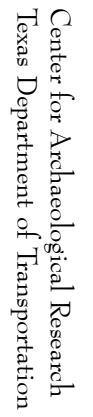

1
00
00
0
0

\#
N
$\sigma \mathrm{O}$

\& 
ISBN: 1-930788-04-5 


\title{
Archaeological Investigations at a Spanish Colonial Site, (41KA26-B) Karnes County, Texas
}

\author{
by Cynthia L. Tennis
}

Contributions by

I. Waynne Cox, Owen Ford, Anne A. Fox, Timothy K. Perttula, and Steve A. Tomka, with Elizabeth J. Reitz and Barnet Pavao-Zuckerman,

\author{
Appendices by \\ Hector Neff and Michael D. Glascock, \\ and David V. Hill \\ Texas Antiquities Committee Permit No. 492 \\ Robert J. Hard and Cynthia L. Tennis \\ Principal Investigators
}

Prepared for:

Texas Department of Transportation

Environmental Affairs Division

Archeological Studies Program, Report No. 26

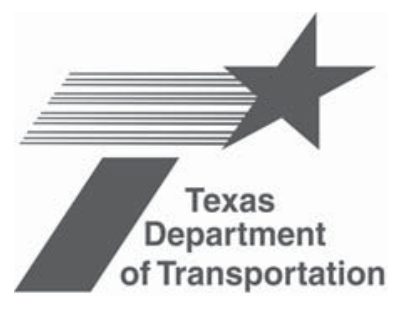

February 2001

Prepared by:

Center for Archaeological Research The University of Texas at San Antonio Archaeological Survey Report, No. 302

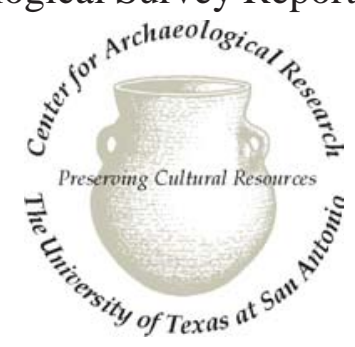




\title{
Archaeological Investigations at a Spanish Colonial Site, (41KA26-B) Karnes County, Texas
}

\author{
Copyright ${ }^{{ }} 2001$ \\ Texas Department of Transportation (TxDOT) and Center for Archaeological Research, \\ The University of Texas at San Antonio (CAR-UTSA)
}

\section{All rights reserved}

TxDOT and CAR-UTSA jointly own all rights, title, and interest in and to all data and other information developed for this project under Contract 57-0XXA3003. Brief passages from this publication may be reproduced without permission provided that credit is given to TxDOT and CAR-UTSA. Permission to reprint an entire chapter, section, figures or tables must be obtained in advance from the Supervisor of the Archeological Studies Program, Environmental Affairs Division, Texas Department of Transportation, 125 East 11th Street, Austin, 78701. Copies of this publication have been deposited with the Texas State Library in compliance with the State Depository requirements.

Printed by Thomas Reprographics Inc., San Antonio, Texas

\author{
February 2001 \\ jointly published by \\ Texas Department of Transportation \\ Environmental Affairs Division \\ Archeological Studies Program \\ Nancy A. Kenmotsu, Ph.D., Supervisor \\ Archeological Studies Program, Report No. 26 \\ A. McGraw, Series Editor \\ and \\ Center for Archaeological Research \\ The University of Texas at San Antonio \\ Archaeological Survey Report, No. 302
}

Printed on acid-free, 60 lb. paper

ISBN: 1-930788-04-5 


\begin{abstract}
In July, 1998, the Center for Archaeological Research (CAR) at The University of Texas at San Antonio (UTSA) was awarded a contract by the Texas Department of Transportation (TxDOT) for artifact analysis and report composition on archaeological investigations at a Spanish Colonial period site in Karnes County in south Texas. The data for this analysis and interpretation was recovered during 1985 TxDOT excavations at site 41KA26.

Forty-five test units and seven shovel tests were excavated resulting in the recovery of approximately 4000 artifacts including over 1000 pieces of animal bone, 445 Native American pottery sherds, 404 pieces of Spanish ceramics, and 256 lithics. Five features, including a faunal refuse dump, a Native-American ceramic dump, and the remnants of an early nineteenth-century jacal structure were identified in moderately well-preserved stratigraphic context.
\end{abstract}




\section{Contents}

Abstract fon

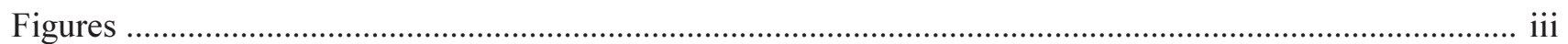

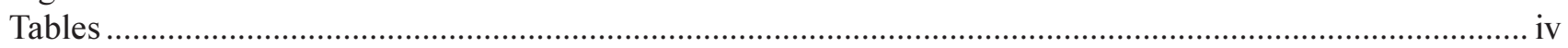

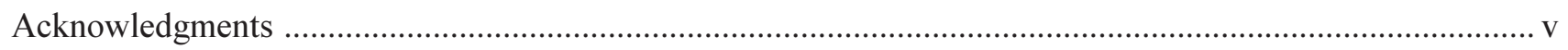

Chapter 1:

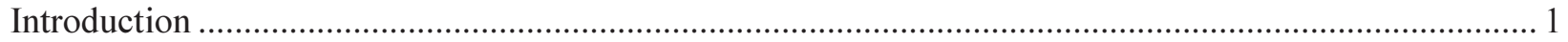

Chapter 2:

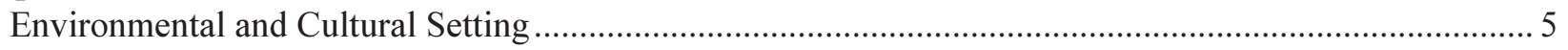

Chapter 3:

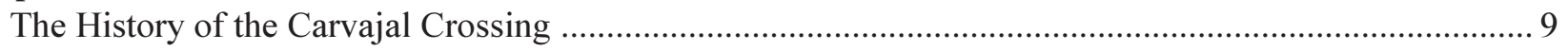

Chapter 4:

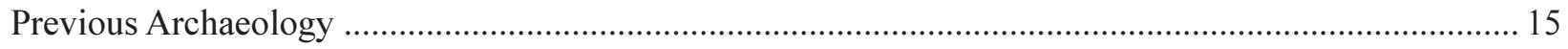

Chapter 5:

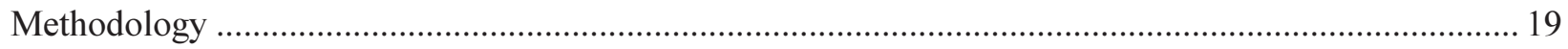

Chapter 6:

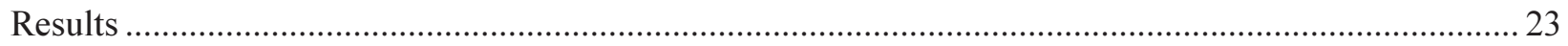

Chapter 7:

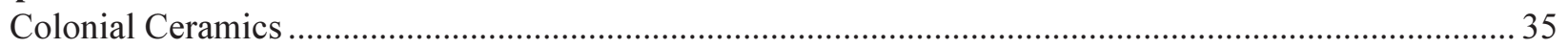

Chapter 8:

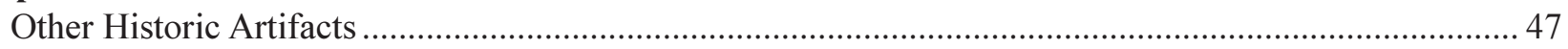

Chapter 9:

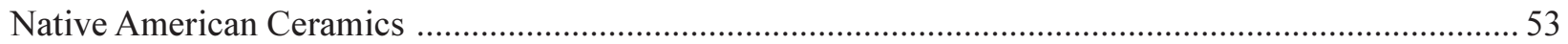

Chapter 10:

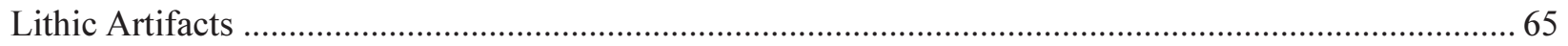

Chapter 11:

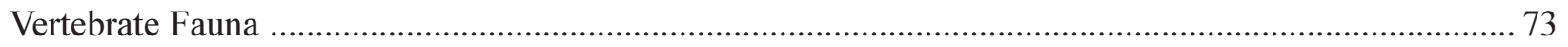

Chapter 12:

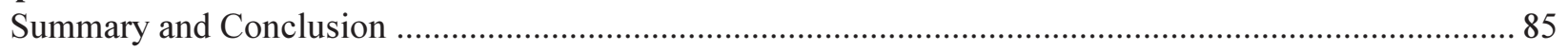

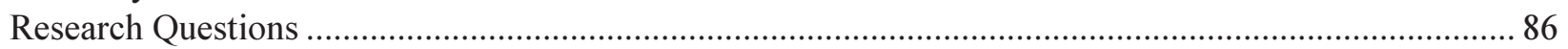

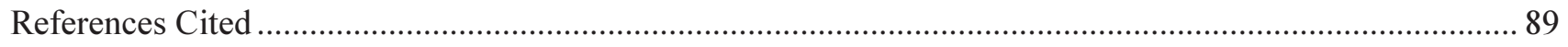

Appendix I:

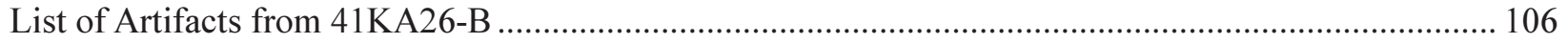

Appendix II:

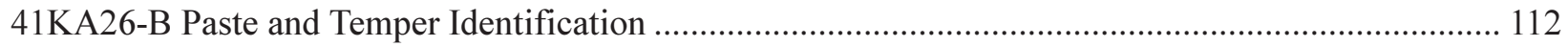

Appendix III:

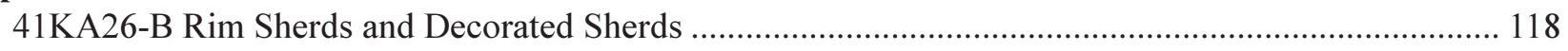

Appendix IV:

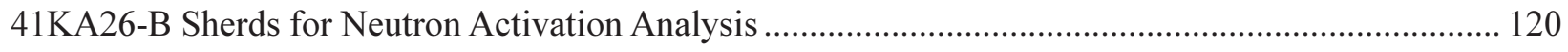

Appendix V:

Instrumental Neutron Activations Analysis of Ceramic ...................................................................... 122

Appendix VI

Petrographic Analysis of Bone Tempered Ceramics ............................................................................. 132

Appendix VII:

41KA26-B List of Proveniences Containing Faunal Material .............................................................. 138

Appendix VIII:

41KA26-B Bone Measurements ..... 


\section{Figures}

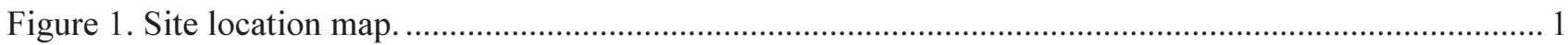

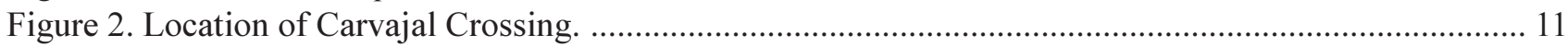

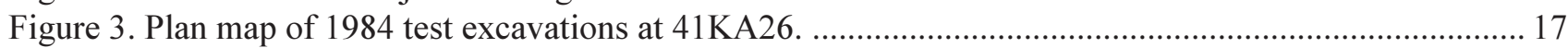

Figure 3a. Enlarged Plan map of 1984 test excavations at 41KA26-A. ................................................... 18

Figure 3b. Enlarged Plan map of 1984 test excavations at 41KA26-B..................................................... 18

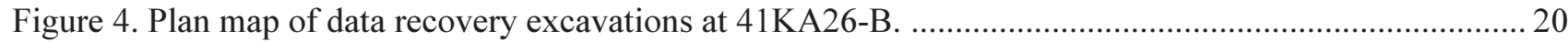

Figure 4a. Enlargement of main area of data recovery excavations at 41KA26-B................................... 21

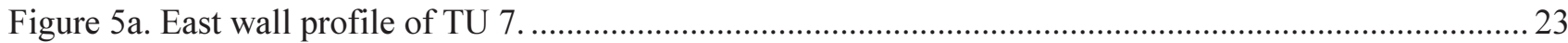

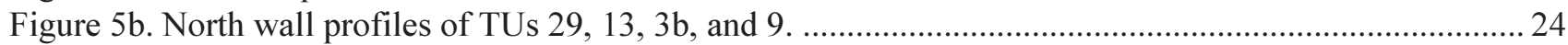

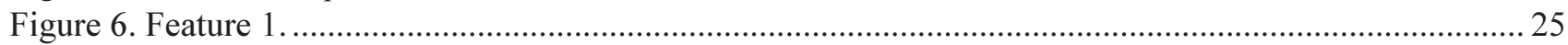

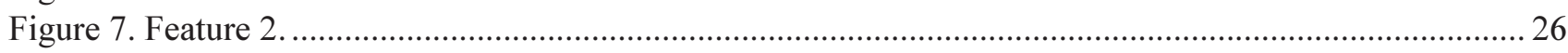

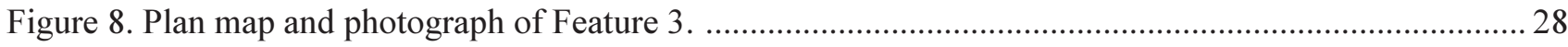

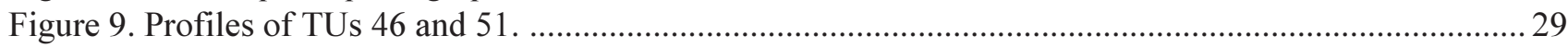

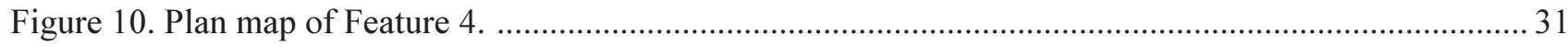

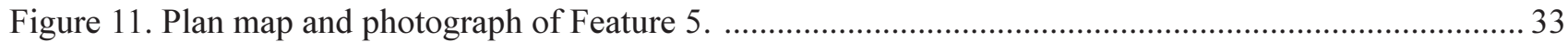

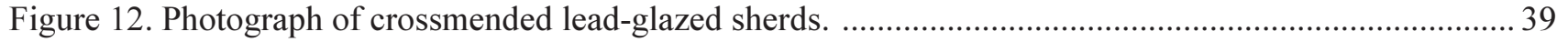

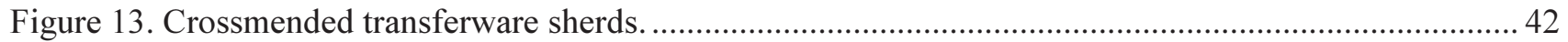

Figure 14. Horizontal distribution of Spanish and European ceramics .................................................... 43

Figure 15. Frequency of Spanish and European ceramic types by level. ...................................................... 44

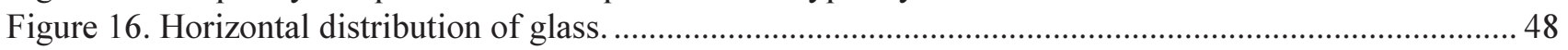

Figure 17. Fragment of possible "Green River" knife from Feature 3 …..................................................... 49

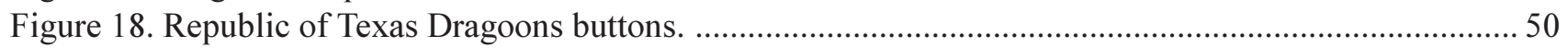

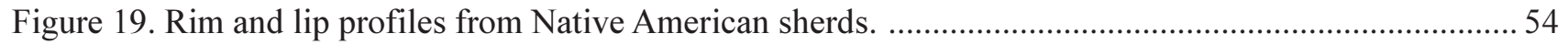

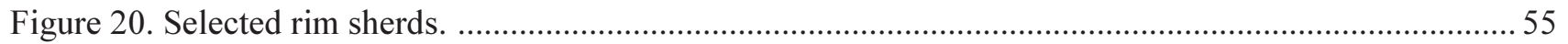

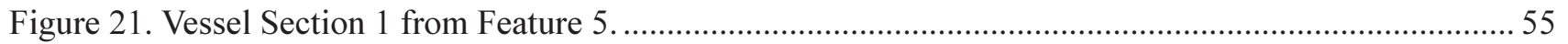

Figure 22. Horizontal distribution and density of Native American ceramics. ..........................................5

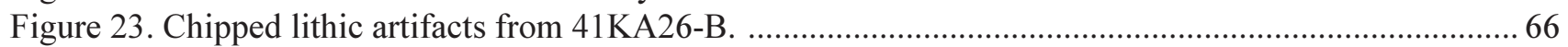

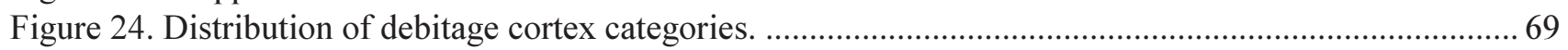

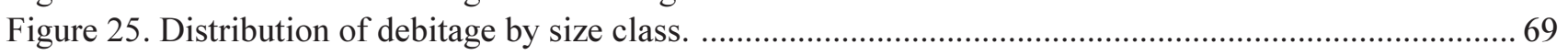

Figure 26. Distribution of platform facet counts among platform-bearing flakes. ...................................... 70

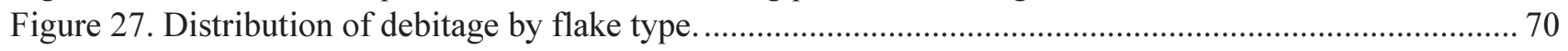

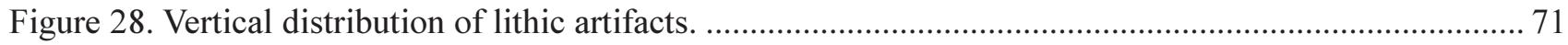

Figure 29. Log Ratio Diagram for archaeological cat elements compared to the modern standard. ................76

Figure 30. Horizontal distribution of vertebrate faunal remains. ........................................................ 81

Figure V-1. Logged Data prior to adjustment for bone temper. .......................................................... 125

Figure V-2. Logged Data after adjustment for bone temper. .............................................................. 125 


\section{Tables}

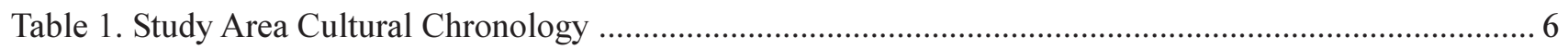

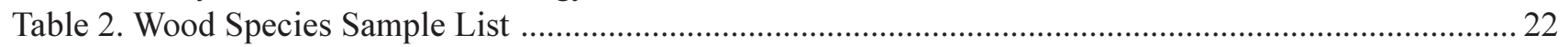

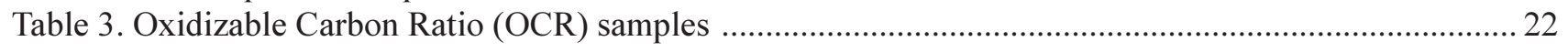

Table 4. Vertical Distribution of Artifacts Associated with Feature 2 ..................................................... 25

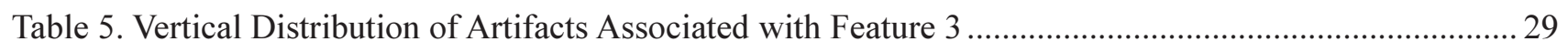

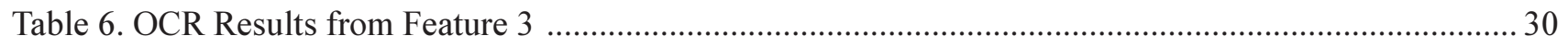

Table 7. Vertical Distribution of Artifacts from Units Associated with Feature 4 ....................................... 32

Table 8. Vertical Distribution of Artifacts from Units Associated with Feature 5 ........................................ 34

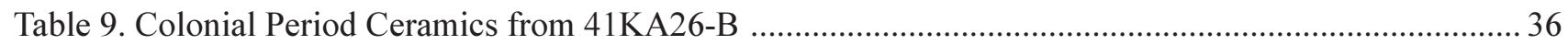

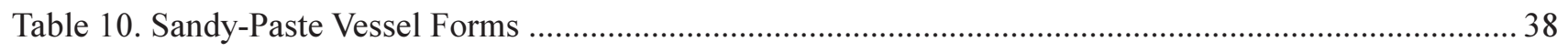

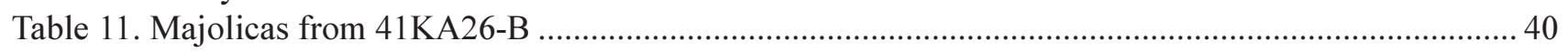

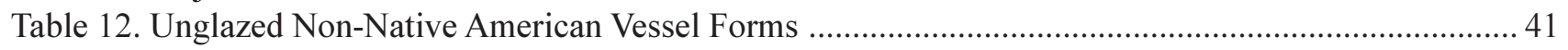

Table 13. Frequency of Temper and Paste Class by Depth (analyzed sherds only) ...................................... 59

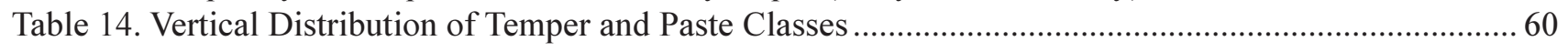

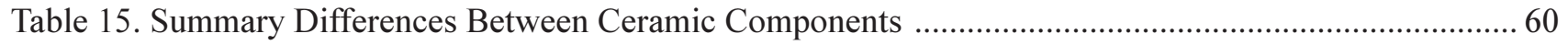

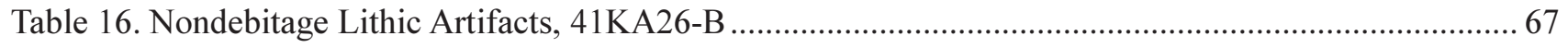

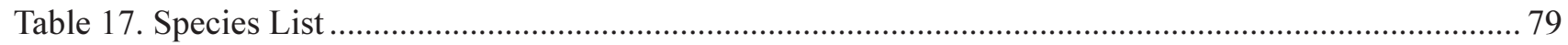

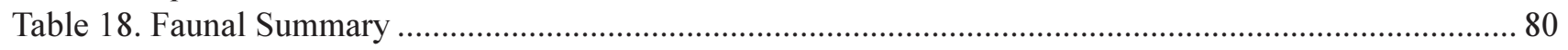

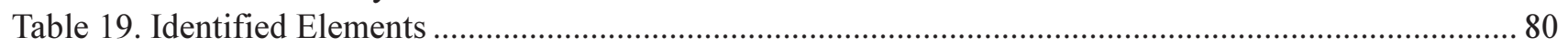

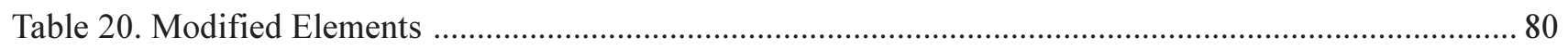

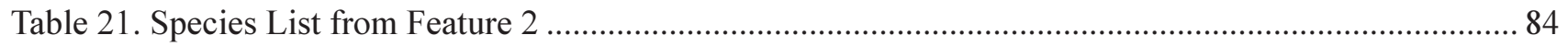

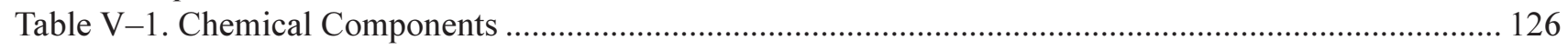

Table VI-1. Petrographic Analysis of Bone Tempered Ceramics from 41KA26-B …................................ 135 


\section{Acknowledgments}

I would like to acknowledge the close collaboration between the many analysts that made this report possible. I would also like to thank Dr. Robert J. Hard, Director of the Center for Archaeological Research, for his input on this project. Maryanne King and Johanna Hunziker, our technical editors, and Bruce Moses and Richard Young our draftsmen, deserve the credit for pulling it all together and making it look professional.

Timothy Perttula would like to thank Elton Prewitt and David Nickels for discussing the ceramics from the Rowe Valley and Biesenbach sites, respectively.

Barnet Pavao-Zuckerman would like to extend thanks to J. Matthew Compton for his assistance throughout the faunal identification, analysis, and report preparation phases of this project, and also to Jayson Wright who assisted with the weighing of faunal materials. 

This page has been

redacted because it

contains restricted

information. 
1) 41KA26-A, a component on the west side of the creek south of FM 887 containing mid- to late-nineteenth century materials in previously disturbed context;

2) 41KA26-B, a component on the east side of the Cibolo immediately south of FM 887 thought to be a eighteenth-century campsite of Native Americans who were attracted to El Fuerte de Santa Cruz;

3) 41KA26-C, a discrete campsite $150 \mathrm{~m}$ north of Area B; and

4) 41KA26-D, the location of El Fuerte de Santa Cruz, $200 \mathrm{~m}$ north of the project area (Goode 1984).

Site $41 \mathrm{KA} 26$ is also thought to be in the vicinity of the 1837 battle fought between the Comanche Indians and Juan Seguin's Texas Dragoons.

Because of the imminent impact along the east side of the Cibolo immediately south of FM 887, data recovery excavations were subsequently conducted by TxDOT within the 15-x-80-m section of right-of-way (ROW) identified as 41KA26-B. Forty-five test units and seven shovel tests were excavated during this phase of investigations. These excavations resulted in the recovery of approximately 4000 artifacts including over 1000 pieces of animal bone, 445 Native American pottery sherds, 404 pieces of Spanish ceramics, and 256 lithics. Also discovered were the remnants of a "jacal-type" structure believed to be associated with early-nineteenth century use of the site.

\section{Project Description}

This report then, attempts to analyze the artifacts and interpret them in a meaningful and accurate way based on the findings of this 15-year-old TxDOT mitigation project. The authors and analysts were given all of the artifacts recovered from the excavation along with copious level and feature forms, notes, and drawings made in the field. However substantial this documentation is, in many cases, it does not completely substitute for the intuitive perceptions that can be gained from actually being on-site. Consequently, many of the stratigraphic and topographic interpretations reported here are those made in-field, with supporting evidence supplied from analysis when and where possible.

\section{Project Design}

Initially, this project was designed to combine and compare artifacts and features recovered during two small TxDOT right-of-way mitigation excavations in south Texas. Results of the 1984 TxDOT testing at this site, 41KA26-B, along the Cibolo Creek (Goode 1984) and the 1998 testing at 41RF1, the Mission Refugio site in Refugio, Texas (Clark 1998), suggested these two sites represented Native and Spanish occupations spanning 100 years during the Colonial period of Texas. A set of research questions was designed to look at the effect of colonization on the Native Americans through time by analyzing changes in ceramic and lithic technology and subsistence patterns and preferences at these two sites.

However, when the mitigation effort at 41RF1 grew to include excavation of the mission cemetery, portions of the mission church and compound, and two large trash pits (Tennis 2001), it was felt that the disparity between the quantity and type of information recovered from the two sites made direct comparisons less viable. A joint decision made by representatives from TxDOT, CAR, and the Texas Historical Commission (THC) allowed analytical results and interpretations from each excavation to form the basis for stand-alone reporting.

Therefore, archival research into the history of the Carvajal Crossing, El Fuerte de Santa Cruz, and the Spanish experience in south Texas, have been combined with analyses of the data recovered during investigations at 41KA26-B in this report to address the following specific research hypotheses more directly applicable to this site.

\section{Research Question 1: \\ Frontier Supply System and its Effect on Native Technology?}

What was the nature of the frontier supply system in Texas between ca. 1730-1830 and what effect did changes in the system have on native American tech- 
nology? More specifically, was there a significant shift or decline at particular times in the availability of goods from Mexico that stimulated shifts in the production of materials in south Texas? Did the political and military turmoil during the Mexican War for Independence (1810-1821), and then later during the period leading up to the Texan revolution (i.e., 1830s), affect the regular transportation of goods from Mexico into Texas? Would such interruptions lead native and non-native people living in New Spain to become more dependent on local Native American products and experience a decline in reliance on Mexican-made goods?

\section{Research Question 2: Effect of Spanish Influence on Native American Ceramic Technologies?}

How did Spanish colonization influence Native American ceramic technologies? Two alternative hypotheses have been proposed concerning the degree of acculturation among Native Americans associated with Spanish institutions in south and central Texas. Ricklis (1996) has postulated that coastal Native Americans used the missions as they would any other resource patch, entering the missions in the spring, at the time that they traditionally moved to inland camps, and leaving whenever they felt the resource patch was no longer providing enough food to justify its continued exploitation (Ricklis 1996:159-168; see Casteñeda 1976 [1942]:81,89). This tendency of occasional, opportunistic use of Spanish institutions by inland Native American groups has also been suggested by archaeological findings and historic documents from the missions in San Antonio (Cargill and Hard 1999, Habig 1968, Schuetz 1980). However, Ricklis (1996:152-156) and these same historical documents also suggest that Native Americans were firmly linked to Spanish missions by the changing social, demographic, and warfare patterns present in this portion of Texas at that time, and it is likely that the degree of acculturation and perhaps mobility was reduced compared to the pre-mission era. The methods and techniques used in ceramic manufacture should reflect a shift to a less mobile and more acculturated life-style.

\section{Research Question 3: Ethnic or Cultural Affiliations of the Ceramics?}

Can ethnic or cultural affiliation of the Native American groups at 41KA26-B be determined through the ceramic assemblage? Thonhoff (1992:10) suggests that El Fuerte de Santa Cruz (or del Cibolo) and the Carvajal Crossing were located in a geographic area that was frequented by many different Native American groups including the "Tonkawa, Coahuiltecan, Karankawa, Apache, Comanche and Wichita." The Tonkawa association with this part of the state is evident in the earliest names for the Carvajal Crossing, "Paso de los Indio Texas y Tancaouse" and "Indios Tancahuas iribu errantes" and in the naming of Tonkawa Creek, a small nearby creek (Thonhoff 1992:12). Paste types and decorative techniques used in Native ceramics at the site may offer some clue to the ethnic or cultural affiliation of the native people in this immediate area.

\section{Project Organization}

This project was conducted under Texas Antiquities Committee Permit No. 492 to complete TxDOT's obligations under Section 106 of the National Historic Preservation Act and the Antiquities Code of Texas. TxDOT funded the project through state appropriations and acted as the agency of oversight management throughout.

Principal investigators for the composition phase of the project were Robert J. Hard, CAR director and Cynthia L. Tennis, associate director. Cynthia Tennis, also served as project archaeologist for the artifact analysis and report write-up portions of the project. Special analysts were: archival research, Waynne Cox; ceramics, Tim Perttula and Anne Fox; faunal, Elizabeth Reitz and Barnet Pavao-Zuckerman; ethnobotanical, Phil Dering; and lithics, Steve Tomka. This report conforms to the Council of Texas Archaeologists reporting standards, and those of the Secretary of the Interior's Standards and Guidelines: Archaeology and Historic Preservation. All documentation, maps, photographs, and cultural material are permanently curated at the Center for Archaeological Research, The University of Texas at San Antonio. 



\section{Chapter 2: Environmental and Cultural Setting}

\section{Cynthia L. Tennis}

\section{Regional Setting}

The project area discussed in this report is located in the South Texas Coastal Plains archaeological subregion of the South Texas Area as defined in Hester et al. (1989). This region includes all of south Texas from the Rio Grande to the Texas Gulf coast. Black (1989:39-40) has subdivided this large and varied subregion into five biogeographical areas based on maritime vs. savanna patterns of resources availability.

Karnes County, the site of 41KA26, is within the largest of these biogeographical areas, the NuecesGuadalupe Plain. This area is dominated by a series of drainage systems which serve many of the state's major rivers as they travel on their way to the Gulf Coast. These southeastward flowing rivers create narrow bands of high-density riparian resources that bisect the otherwise broad, low-density resource areas of thorny-brush and grassland savanna (Hester 1989a).

The subtropical climate of this portion of the Tamaulipan Biotic Province (Blair 1950) changes from arid in the northeast to sub-humid in the southwest near the coast. Winters are mild and dry with occasional drizzle associated with cold fronts. Summers are hot with temperatures in the $90 \mathrm{~s}$ and 100s. Rainfall averages 33.2 inches annually and the growing season is an average of 281 days per year (Natural Fibers Information Center 1987).

Today, vegetation is dominated by mesquite and thorny shrubs, a combination that, interspersed with grasslands, may have been present to varying degrees for the past 6000 years (Hall et al. 1986; Hester 1989a; 1995). Trees and brush species common to the area include: mesquite (Prosopis glandulosa), post oak (Quercus stellata), live oak (Quercus virginiana), huisache (Acacia farnesiana), black brush (Acacia rigidula), white brush (Aloysia gratissima), and prickly pear (Opuntia lindheimeri). Blair (1950) has also identified over 100 animal species inhabiting the Nueces-Guadalupe Plain including: the white-tail deer
(Odocoileus virginianus), mountain lion (Felis concolor), bobcat (Lynx rufus), black-tailed jackrabbit (Lepus californicus), Texas pocket gopher (Geomys personatus), and western diamondback rattlesnake (Crotalus atrox). The archaeological record also indicates that bison, pronghorn, black bear, and wolf were also present at one time (Hester 1989a).

\section{Project Setting}

The project area is located in north central Karnes County, one mile south of the Wilson County line near the town of Pawelekville. It is situated on a high terrace on the east side of the Cibolo Creek. The surface is relatively level, following a gradual westerly slope to the terrace edge where it drops sharply to the narrow floodplain of the creek. Although no soil survey has been published for Karnes County, soils in the immediate project area were described during excavation as a combination of dark grayish brown loamy sand and yellowish gray-brown silty loam. Today, the 12-m section of the old ROW nearest FM 887 is heavily wooded while the newly added section of ROW extends south for an additional $12 \mathrm{~m}$ into a plowed field.

\section{Prehistoric Cultural Setting}

As noted above, the project area is in the South Texas Coastal Plains archaeological region. Several comprehensive syntheses of the cultural history for the Southern Texas Plains have been compiled (Black 1989, 1995; Hester 1980a; Tomka et al. 1999). Hester (1995) expands on the tool typology for the interior regions while Ricklis (1995a) presents a more precise chronology for the coastal areas based on radiocarbon data. These syntheses agree that archaeological investigations within the subareas of south Texas have been unevenly distributed and that much of the coastal area available for occupation during prehistoric times is now covered by gulf waters. Thus our understanding 
of chronological changes in prehistoric lifeways in this part of the state is quite limited. As the focus of this report is the Spanish-Colonial period in south Texas, only a brief summary of the prehistoric period is given here. A detailed treatment of the historic period is presented in the following chapter.
As shown in Table 1, south Texas prehistory has been divided into loosely defined periods of technologic and adaptive change. The 3,200-year Paleoindian period is represented in south Texas by occasional surface finds of diagnostic Clovis, Folsom, Golondrina, Plainview, and St. Mary's Hall point types

Table 1. Study Area Cultural Chronology

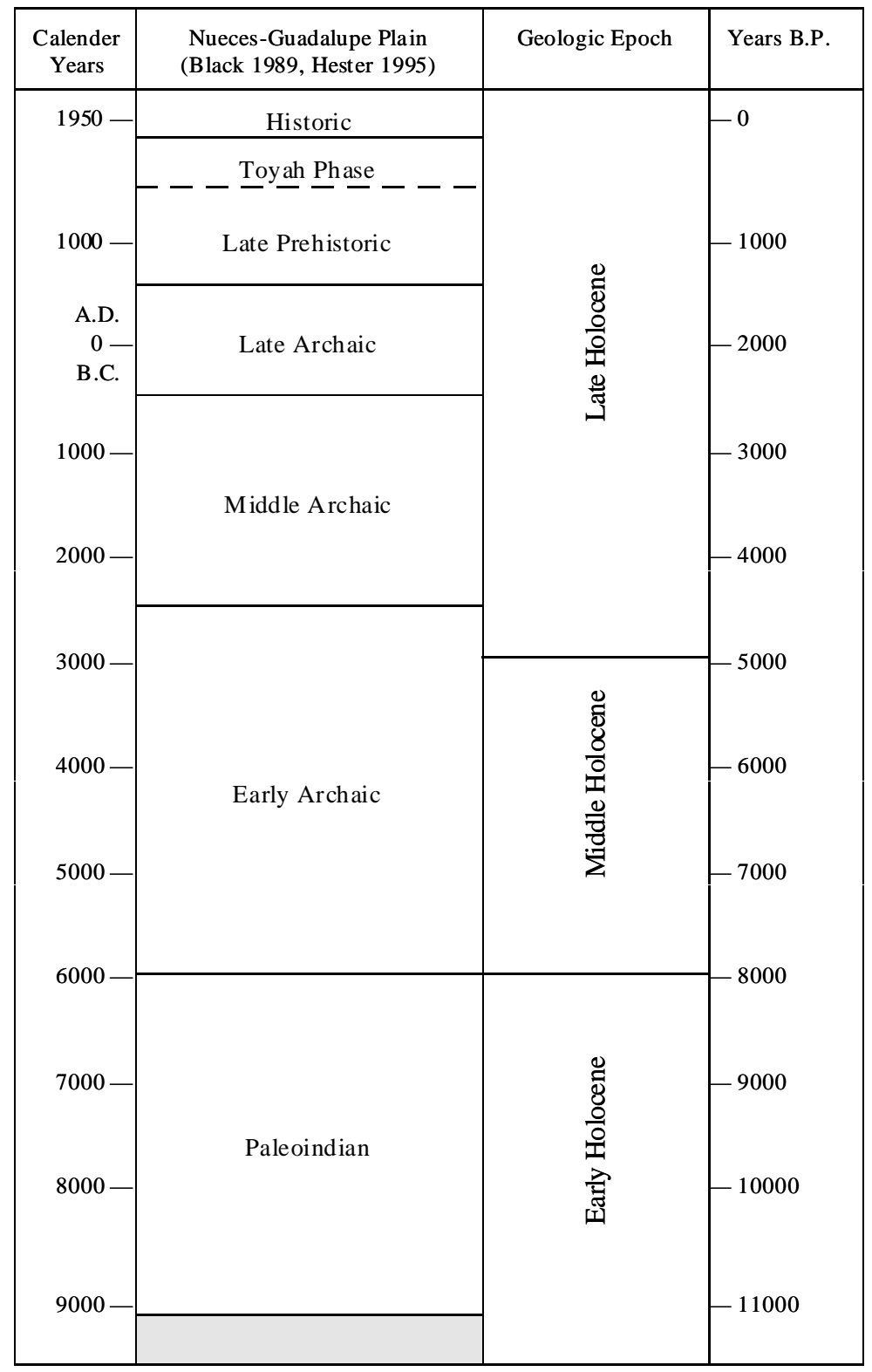


(Hester 1980b, 1995). Black (1989) suggests that low population density, small band size, and large territorial ranges can be inferred from these sparse remains. While it is assumed that these early people were hunting large game known to have been present in this region (Hester 1995; Suhm 1980), the bones of small mammals, reptiles, and amphibians recovered in association with Paleoindian-period radiocarbon dates at the Berger Bluff site (Brown 1987) suggest the use of a more generalized adaptive strategy. Clovis points and extinct faunal material from the McFadden Beach site on the eastern coast (Hall 1998) testify to the presence of more Paleoindian sites beneath the gulf waters.

Early Archaic sites are not common in south Texas, but the majority of those reported in the NuecesGuadalupe Plain occur on high terraces or deeply buried in alluvial deposits (Black 1989). Along the coast, Early Archaic components occur in dense oystershell layers (Ricklis 1995a). Subsistence data from this time period is limited to freshwater and estuarine faunal material. The low population density suggested by the limited number of sites from this time period could reflect unfavorable drought conditions in south Texas that encouraged an adaptive shift to the more well watered region of central Texas (Black 1989; McKinney 1981; Ricklis 1995a; Story 1985).

Based on an apparent increase in site frequency and data from the large cemetery site, Loma Sandia (Taylor and Highley 1995), populations and occupations in the northern portion of south Texas seem to increase during the Middle Archaic (Black 1989; Hester 1995). Open campsites are found in upland and alluvial settings. The hearths, earth ovens, and burned rock accumulations from this time period suggest an increased reliance on plant resources similar to that documented in central Texas (Hall et al. 1986).

Population densities continued to increase in the Nueces-Guadalupe Plain during the Late Archaic period (Black 1989). A broader-based subsistence pattern is suggested which focused on plant resources and small mammals (Black 1989). Numerous smallstemmed bifaces made from Edwards chert found in south Texas and the occurrence of marine-shell pendants in central Texas indicate some degree of regional trade (Black 1989; Hester 1995).
Numerous, well-preserved sites with distinctive artifact assemblages make the Late Prehistoric the best known, if not completely understood, of the Prehistoric periods. Arrow points and pottery are the diagnostic markers of this period which immediately preceded the arrival of the Spanish in south Texas (Black 1989). Hester (1995), Black (1989), and Ricklis (1995a) agree that the early part of the Late Prehistoric is a complicated period with many overlaps in arrow-point styles and inconsistent presence of ceramics. By A.D. 1250-1300 however, material assemblages solidify with central Texas Toyah-horizon markers, especially the Perdiz point and bone-tempered ceramics, present in the Nueces-Guadalupe Plain subregion in south Texas. Faunal assemblages include an abundance of bison, along with white-tailed deer, pronghorn, and other smaller mammals (Hester 1995). These widespread cultural traits, which appear to have originated in the southern Plains and spread rapidly south, may represent actual population movement or diffusion of cultural traits (Black 1989; Hester 1995).

Black (1989) states that associating Late Prehistoric archaeological cultures in south Texas with historic ethnographic groups has had very limited success due to inadequate ethnohistoric documentation and the lack of distinctive material assemblages associated with known groups. Hester (1989b) concludes that Native American groups evidently ranged over large, poorly defined territories and by the Historic period groups native to south Texas had been largely displaced by intrusive groups from the north and west. 



\section{Chapter 3: The History of the Carvajal Crossing}

\section{Waynne Cox and Owen Ford}

Shortly after 1519 when the first voyages off the Texas Gulf coast were conducted by Alonso Alvarez de Pineda, Spain regarded all of this new land to be part of its vast empire. But when a few exploratory expeditions into the wilderness failed to produce new sources of wealth, the Crown's interest in this northern territory declined. However, in 1685, Spanish officials learned of a bold venture designed for the coast by French explorer, René Robert Cavelier, Sieur de la Salle. His ill-fated enterprise to set the French flag on the Gulf was doomed almost from the start, but the mere threat of a French intrusion on the outer fringe of their northern territory was enough to set into motion real and far-reaching action designed to curtail this threat to the entire frontier of Nueva España.

As soon as the reports of the French settlement reached Mexico City, the Spanish viceroy dispatched expeditions, by land and sea, to search for La Salle's colony. The first sea expedition launched from Havana, in January of 1686, found little to confirm the French threat, but a second, sent forth late in the same year, found the wreck of a large vessel and weapons of French origin between Corpus Christi and Matagorda bays (Chipman 1992:23-79). In that same year, Alonso de León mounted a land entrada, which reached the Rio Grande where he too found wreckage of European origin. Over the next four years de León would lead five more expeditions into Texas. On April 1, 1689, he crossed the Rio Grande for the fourth time, but this time his mission was to colonize the frontier as well as find the French (Frantz 1976:26).

While the concern of the Spanish officials was focused on the intruders, there was another faction that was equally adamant about the state of the frontier, the Franciscan Colegio de la Santa Cruz de Querétaro. Among the first priests to cross the Atlantic to found the College were Fathers Damián Massanet and Francisco Hidalgo. They brought with them an unrelenting drive to carry their faith to the wilderness and establish missions for the Indians of this vast new land (Weddle 1968:9-10). The French intrusion had confirmed to the Spanish officials what the church had always maintained, that the country must be possessed, and not merely claimed. Father Massanet accompanied de León on his fifth entrada, and the first Spanish mission in Texas, Mission San Francisco de los Tejas, was established in east Texas on the banks of the Neches River in May, 1690 (Weddle 1968:15). In 1716, Captain Don Domingo Ramón, accompanied by Fathers Isidro de Espinosa and Antonio Margil, returned to the province to establish six permanent missions and a presidio in the land of the Tejas (Foster 1995:109).

It soon became obvious that to adequately support the struggling presidio and missions, the establishment of an additional mission midway into the interior of the province was required. Father Antonio de San Buenaventura y Olivares gained the support of the new viceroy, the Marqués de Valero, and in April, 1718 an expedition headed by Martín de Alarcón arrived at the San Antonio River. In early May, both the new mission, San Antonio de Valero, and the Villa de Béjar were founded (Chipman 1992:121; Weddle 1968:149). In December of the following year Alarcón tendered his resignation and Joseph de Azlor y Virto de Vera, Marqués de San Miguel de Aguayo was chosen to succeed him as Governor.

In 1721, the governor mounted the largest expedition ever to cross the Rio Grande, in fact the largest to cross for another 115 years (Weddle 1968:159-161). Although disappointed that he would not gain fame as the one to drive the French from the territory, since a truce had been effected between Spain and France, he strengthened the frontier by establishing three new missions, and the presidio de Nuestra Señora del Pilar de los Adaes. He also established another presidio and mission — presidio de Nuestra Señora de Loreto and Mission Nuestra Señora del Espíritu Santo de Zúñiga - on the former site of La Salle's colony where foreign aggression was most feared (Weddle 1968:164; Faulk 1996:5:333; Roell 1996a:4:1062-1064). The site was generally known as La Bahía, a short form of 
La Bahía del Espíritu Santo, or the Bay of the Holy Spirit, for Matagorda and Lavaca bays, the large bodies of water located nearby. This mission was established to serve the Coco, Cujanes, and Copanes, subdivisions of the Karankawa that occupied the entire coastal region of the province. Trouble soon developed between the Indians and the Spanish, and in 1726 , both the presidio and the mission were relocated some ten leagues further inland to Tonkawa Bank in Victoria, and then to Mission Valley on the Guadalupe River (Hindes et al. 1999:85-86; O’Connor 1966:12-16; Walter 1999:97-99).

In 1724, Brigadier Pedro de Rivera y Villalon was dispatched by the viceroy to inspect and evaluate the frontier defenses of New Spain. The tour lasted until June of 1728 and covered over eight thousand miles. Among his recommendations was the reduction of the east Texas garrisons and the relocation of the three Querétaran missions to new sites on the Colorado River, near present-day Austin. Viceroy Antonio de Aviles, the Marques de Casafuente, acting on the recommendations, reduced the presidios and moved the missions in July of 1730 . The Colorado River location was not acceptable to Father Paredas, the guardian of the college, and the missions were again moved to the San Antonio River basin on March 5, 1731. Nuestra Señora de la Purisima Concepción de los Hasinais became Nuestra Señora de la Purisima Concepción de Acuña, and was located between San Antonio de Valero and the new site of San José y San Miguel. San José de los Nazonis, now San Juan Capistrano, and San Francisco de los Neches, now San Francisco de la Espada, were assigned lands farther to the south (Habig 1968:122-125).

Another recommendation of Brigadier Rivera was that the frontier be settled with stable families, believing that "one permanent Spanish family would do more to hold the country than a hundred soldiers." On March 9, 1731, fifty-six Canary Islanders arrived at the presidio to form the nucleus of the Villa of San Fernando de Bexar, the first civil settlement of Texas (Chabot 1937:141).

Although the new location of presidio de Nuestra Señora de Loreto and Mission Nuestra Señora del Espíritu Santo de Zúñiga proved to be a prosperous location, the government realized that their resources along the vast frontier were spread dangerously thin. Don José de Escandón was dispatched to inspect the Seno Mexicano to formulate a more effective defense against the encroachments of the English and French. Among his recommendations was the removal of the presidio and mission from the Guadalupe River valley to a location farther to the south and west. In 1749, a site on the San Antonio River, ten leagues southwest of its former location, was considered suitable for both the presidio and mission, as well as a civil settlement (O’Connor 1966:18-22).

The missions each developed their own individual acequias (irrigation ditches) that watered their fields along the San Antonio River. In addition, they were assigned summer pastures for their ever-expanding herds of cattle, sheep and goats. Mission Valero had land to the northeast of Bexar from the head of the San Antonio River to Cibolo Creek, as well as to the south along the west side of the river. Below Valero's northern pasture and between the river and the creek was the assigned pasturage of Concepción. San Juan Capistrano had land adjoining Concepción's on the south. Their grant extended five leagues east of Eagle Creek on the road to La Bahía, and south to " $E l$ Rincón" (the corner), the confluence of the San Antonio River and Cibolo Creek. Up creek were "the healing springs," the sulfur waters of Sutherland Springs (Jackson 1986:38-40), and the lands in this vicinity, on the eastern bank of the Cibolo, were assigned to Mission Espíritu Santo.

The site, where present-day FM 887 crosses Cibolo Creek in northern Karnes County, under consideration by this study lies near the southern end of the Mission San Juan grant. The natural rock-bottomed ford of the Cibolo was recognized as a vital crossing in Spanish Colonial times and probably before. Located on the La Bahía road halfway between the town of San Antonio de Béxar and the final site of La Bahía, at present-day Goliad, it was a strategic location of vital importance, and undoubtedly was a known stopping point for travelers along this route (Figure 2). A small Spanish fort was established near the crossing in 1734 to protect the mission herds from the frequent livestock raids by Indians, primarily the Apache. The small post was variously known as El Fuerte de Santa Cruz del Cibolo, 
El Fuerte de Santa Cruz, or El Fuerte del Cibolo. Governor Manuel de Sandoval, who took office in 1734, strengthened the garrison at San Antonio with soldiers moved from Los Adaes, La Bahía and the Rio Grande.
To protect the presidial horses he directed that they be moved to this secluded spot, and a small garrison was then assigned to the new fort to guard them (Thonhoff 1992; 1996a:3:23).

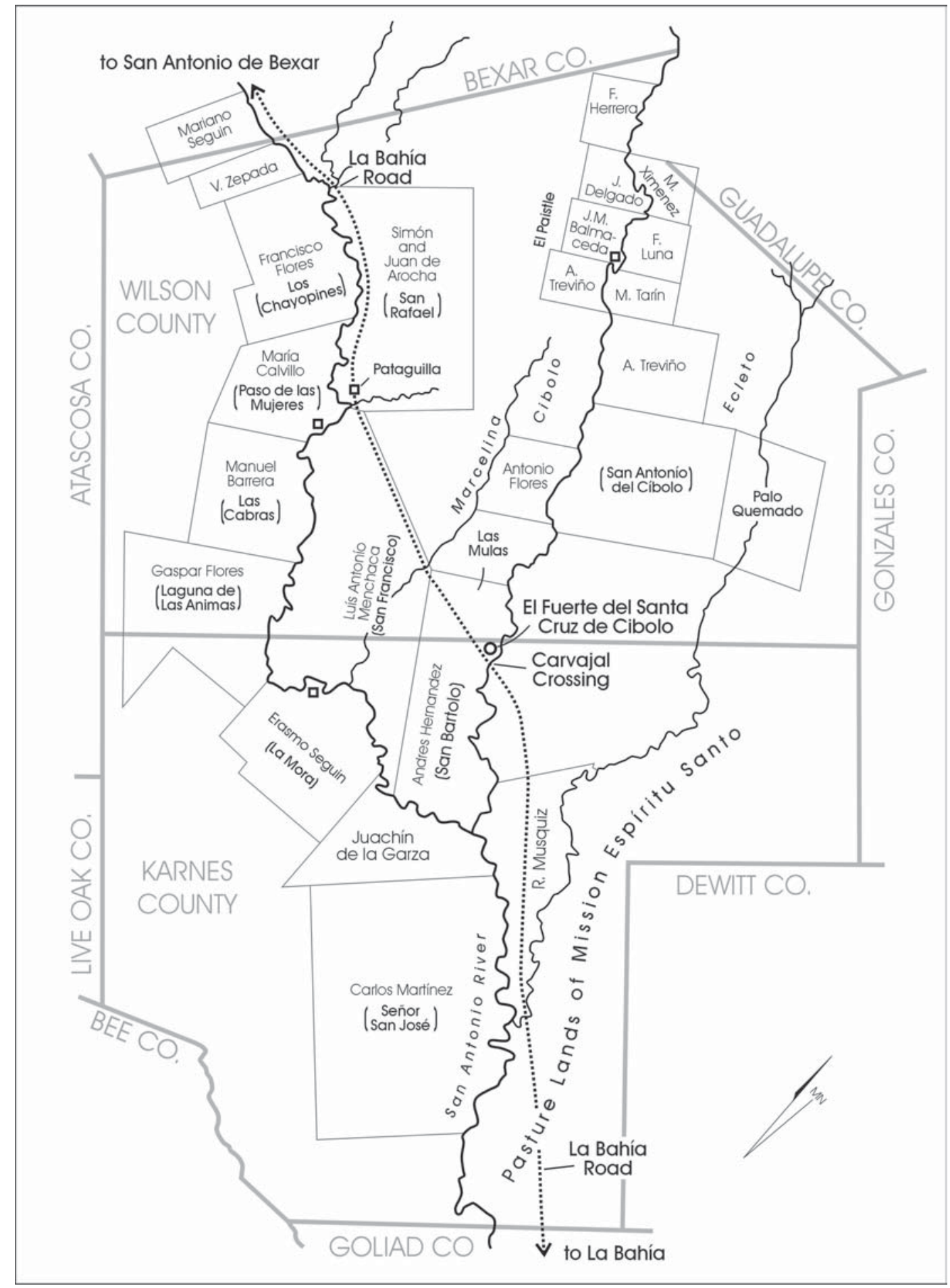

Figure 2. Location of Carvajal Crossing.

Adaptation based on illustration by J. Jackson (1991) in El Fuerte del Cíbolo, Sentinel of the Béxar-La Bahía Ranches (Thonhoff 1992) 
Relationships with the Apache had been difficult from the beginning, but in 1733 a number of attacks fractured the guise of peace that had developed. Raids on the presidio and mission stock, and attacks on individuals frightened the citizens of Béxar. Then, in September of 1737, the Indians attacked the presidio horse herd pastured at Fuerte del Cibolo, carrying off more than a hundred horses and wounding Juan Cortinas, the foreman of the ten soldiers assigned to guard the herd. The raid was reported to Béxar and Joseph de Urrutia, captain of the presidio, ordered fifty men to pursue and recover the herd, but the Apache lead was too great. As a result of this raid, the guard at the fort was increased to eighteen men and an officer, with instructions to remain "especially vigilant." However, on December 2, at midnight, the Apache struck again. Again the raid was reported, but the Indians could not be overtaken, and more than three hundred horses were lost. Because of this action, the council met and determined that the horses were to be moved near the presidio, and a guard of twenty men detailed to protect them. The post on the Cibolo was abandoned (Dunn 1911:237-244).

Despite the constant threat posed by the Apache, a few settlers still attempted to establish ranches in the rich grasslands along the Cibolo. Andrés Hernández established the oldest private ranch in Texas, in the vicinity of the abandoned outpost. The records of the existence of the ranch are dated April 12, 1758 and infer that the original title was granted to Andrés' father, Francisco, around 1736 during the occupation of the Cibolo garrison (General Land Office - Spanish Archives [GLO-SA] 1758) (Figure 2). Francisco Hernández, a soldier with the Alarcón expedition of 1718 , had been granted permission to establish such a ranch, a claim ratified in 1737 by governor Carlos Franquis de Lugo. After the Apache raids of December, Corporal Andrés Hernández was ordered to take nine soldiers to the pasturage and recover what was left of the herd (Jackson 1986:61). Hernández called his ranch San Bartolomé. It consisted of four leagues and eight caballerías, an area equal to 18,599 acres. Luis Antonio Menchaca, another son of one of the Alarcón soldiers, also received a grant at the same time. Menchaca's ranch, San Francisco, to the northwest and bounded by the La Bahía road, comprised eight leagues and four caballerias, or 49,107 acres (Thonhoff 1992:13-14).
With the relocation of the missions of Espíritu Santo and Nuestra Señora Rosario, in 1749 and 1754 respectively, travel increased along the La Bahía road and other ranches were established within the area. The road originally followed the river on the west side, but in 1755 Captain Manuel Ramírez de la Piscine laid out a new route on the east side to more directly connect La Bahía and Béxar (Jackson 1986:44). Scattered settlement and the presence of more travelers did little, if anything, to deter depredations within the area. Upon the arrival of the new governor, Juan María Vicencio de Ripperdá, the ranchers formed a grievance committee to plead for protection (Morfi 1935:II:418). The committee called for a new post to be established midway between the two presidios that would be manned with a relief column of twenty-one men transferred from the presidio at San Sabá. No action was taken at the time, but when the troops were recalled from Los Adaes and Orcoquisac, in the winter of 1770, the governor decided to use them for the defense of El Rincón (Jackson 1986:107-108). For the site of his new garrison he selected the "Towankoni crossing about halfway between the presidio [at San Antonio de Béxar] and La Bahía" (Castañeda 1936:IV:79-82).

There seems little question that the location was the same as the previous fort, but this one was constructed in a more substantial form. Governor Ripperdá wrote to the viceroy in April 1771 requesting official sanction for the fort, apparently unaware that such a fort had already been dictated by the order of Marqués de Rubí in the Reglamento e instruccion para los presidios que had forman en la linea de frontera de Nueva España (Brinckerhoff and Faulk 1965:1-67). The Royal Regulations specified that a detachment of twentyone men be stationed on the banks of the Arroyo del Cibolo. The Adaesanos, who had been dispossessed of their lands in east Texas, were offered lands near the fort, but they refused, pleading to return to their former settlement (Bolton 1915:114).

The reestablished fortification was garrisoned from May 1771 until March 1782. Fray Morfi, upon viewing the fort in 1778, described it as "the wretched fort of Santa Cruz, built with wooden stockade" (Morfi 1935:I:69). By 1773, the enemy had changed, but the hostilities continued. The Comanche raids had frightened the Apaches so badly that they left the area 
(Jackson 1986:125). Although Indian troubles abated somewhat during 1779, the summer of 1780 brought renewed hostilities and the entire frontier came under attack. In March 1782, the Commandant-General ordered the withdrawal and destruction of the fort. On March 17, a force was dispatched from Béxar with two carts to return the cannon and ornaments of the chapel. The structure was then burned to prevent its use by the Indians (Thonhoff 1992:63-64).

There is one vague reference to the study area from the Texas Revolutionary period. On February 28, 1836, Captain Juan N. Seguín was dispatched from the Alamo to convey the situation to Colonel Fannin and request his reinforcement to the besieged fort. Fannin replied that he was under order from General Houston and advised him to communicate with him at Gonzales. Upon his arrival he was ordered to remain at Gonzales and await further orders. General Houston ordered Captain Salvador Flores, with twenty-five men of Seguín's company, to the "lower ranchos on the San Antonio River, to protect the inhabitants from the depredations of the Indians" (de la Teja 1991:80). This would have placed them in the vicinity of the crossing. While Seguín's company is generally referred to as a cavalry company, it may well have also been considered dragoons, or horse mounted infantry. While there is no definite archival evidence that they engaged the Comanche at the crossing it is a likely point of contact.

In 1838, José Luis de Carvajal, the descendant of a Canary Islander family, received as a gift from his aunt, Barbara Sánchez, a tract of land she had inherited in the Hernández grant. Carvajal, married to María de Jesús Flores in May 1830, first built a dugout structure near the crossing which was reported to have been covered with green saplings. It existed as late as 1938 or 1939, at which time it was destroyed by the landowner (Thonhoff 1970). Eventually the Carvajals were to raise nine children on the homestead and ranch they established near the ford, which became known as the Carvajal Crossing after their occupation (Chabot 1937:33-34, 61; Thonhoff 1992:87-89). During the Carvajal occupation, it was reported that a village of Lipan Apache occupied the east bank of the crossing, apparently in peace with the Carvajals until both were driven off the land by the Comanche (Thonhoff 1964).
In 1852, a young Franciscan priest, Father Leopold Moczygemba, arrived in Texas to serve the German communities of New Braunfels and Castroville. He contacted his fellow Poles urging them to leave the Prussian oppression and severe economic condition of Upper Silesia and immigrate to Texas. In 1854 the first group of immigrants, including four Moczygemba brothers, arrived in Texas. Father Moczygemba would escort them to a site he had selected. Three months after beginning their journey they arrived at what would soon be called Panna Maria (the oldest permanent Polish settlement in America), a few miles south of the crossing (Temple 1996:5:44-45).

In 1873, as Panna Maria began to grow, a group of forty families decided to start a new settlement, five miles to the north, which they named Czestochowa (now Cestohowa), named after the city of the same name in Poland (Thonhoff 1996b:2:22-23). In about 1890 , the town of Kosciusko was established north of the crossing by the San Antonio and Gulf Railroad to serve as a rural supply point for the Polish and German settlers who had been brought into the area (Hazlewood 1996:3:1158).

It has been reputed that, ca. 1840, a small trading post was established near the crossing by an individual named George Rhyme. However, this occupation is not confidently documented (Thonhoff 1964). It has also been speculated that this site once served as a Texas Ranger post. This occupation also can not be substantiated in the records. It appears questionable however as the Carlos Rancho, some twelve miles south of Goliad, served that purpose on other occasions (Roell 1996b:1:977-978).

The site later became a portion of the Maria I. Leal Survey (GLO 1969). The Krawietz family acquired the property in the early 1900s (Thonhoff 1992:83). In 1949, the Texas Highway Department constructed FM 887, and the bridge at the crossing was built at that time. An elevated bridge replaced this low-water bridge late in 1984 (Thonhoff 1992:98). 



\section{Chapter 4: Previous Archaeology}

\section{Regional}

Black (1989), Shafer and Bond (1985), and Tomka et al. (1999) provide comprehensive overviews of the regional archaeology in south Texas. Several major investigations form the basis for our knowledge of Prehistoric and Historic occupations in this region. The most notable of these is the 15 year, multi-phase archaeological project preceding the construction of the Choke Canyon Reservoir in Live Oak and McMullen counties that resulted in the identification and recording of over 400 Prehistoric and Historic sites. This work is reported in 12 volumes published by CAR, as well as several smaller reports (see Hall et al. 1986; Lynn et al. 1977; Wakefield 1968). Hester and Parker (1970) present a detailed examination of the cultural material remains associated with the Late Prehistoric Toyah-phase component at the Berclair site (41GD4) in Goliad County.

More pertinent to this project are the archaeological investigations at Spanish-Colonial sites in the south Texas region. Gilmore (1973) reports on the artifacts recovered during excavations at the Keeran site in Victoria, Texas. This site, 41VT4, is thought to be the location of La Salle's 1685 Fort St. Louis and the first site of the Spanish presidio La Bahía del Loreto. The probable second site of the presidio La Bahía del Loreto (1726-1749), 41VT8, was investigated by members of the 1968 Texas Archeological Society (TAS) field school (Davis 1968). TAS members are also responsible for the archaeological work at 41VT10, the presumed site of the second Mission Espíritu Santo de Zuñiga, the third site of Mission Espíritu Santo, 41VT11, and the mission's nearby sandstone quarry, 41VT121. These investigations are described in Hester and Walter (1998). An in-depth study of the 1995 work at 41VT11 formed the basis for a Master's thesis by Walter (1997). National Park Service excavations in 1935 at the fourth and final location of this mission in Goliad State Park, 41GD1, were also reported in a Master's thesis by Mounger (1959). More recent smaller projects at 41GD1 have been conducted by Hunziker and Fox (1998) and Ricklis (1998). Site 41GD7, the final location of the La Bahía del Loreto presidio is also within Goliad State Park. In 1973-1974, the Historic Sites and Restoration Branch of the Texas Parks and Wildlife Department conducted excavations at the site of Mission Rosario (41GD2) in Goliad State Park in Goliad County. During these two years of investigations many of the mission walls and rooms originally exposed during 1940-1941 National Park Service excavations were re-exposed and a large artifact assemblage was collected and analyzed (Gilmore 1974, 1975). In 1999, Texas Parks and Wildlife Department contracted with CAR-UTSA to excavate a series of test units within the compound at Mission Rosario to determine the current depth of the intact Colonial deposits and the base of the foundations and walls (Nickels 2000).

\section{Karnes County}

The majority of archaeological investigations in the study area have been conducted at the survey level. In Karnes County, many of the 103 sites listed as of 1998 were recorded during archaeological assessments for mining and oil leases and watershed modifications in the northeastern part of the county (Andrews 1981; Crawford 1971; Espey et al. 1985; Fox 1974; Kelly and Highley 1979; Kelly and Roemer 1976; Kelly et al. 1977; Kotter and Guy 1980; McGraw 1979; Nightengale and Bement 1982; Roemer 1980; Schroeder et al. 1997; Smith 1978; Uecker and McKenzie 1991). All but eight of these sites are Prehistoric, covering the 9,000-year span of human occupation in Texas from the Late Paleoindian through the Late Prehistoric periods. The eight Historic period sites include three post-1850 cemeteries, 41KA59 (Kotter and Guy 1980), and 41KA53 and 41KA54, the Asher and Odom cemeteries (Kelly and Highley 1979). Also recorded were: $41 \mathrm{KA} 21$, a ca. $1850 \mathrm{~s}$ house site (Kotter and Guy 1980); 41KA68, a ca. 1869 
stone dam (Espy et al. 1985); 41KA55, a ca. 1860s hand-dug well; and 41KA56, a ca. 1900s schoolhouse foundation (Kelly and Highley 1979).

A limited amount of testing has been conducted at sites in Karnes County. Kotter and Guy (1980) excavated a number of shovel tests during the Critical Areas Treatment Measures survey for the Ecleto Creek Watershed, Wormser and McGraw (1988) used three test units and three backhoe trenches to test 41KA87, a Late Archaic and Late Prehistoric site along State Highway 72 near Kenedy. Surface collection and one test unit were performed at 41KA101 (Schmiedlin 1993), revealing a Toyah horizon assemblage similar to others reported in south Texas (Hester and Parker 1970). Evaluative testing was also conducted at 41KA95 (Tucker and Warren 1992) and 41KA14 and 15 (Mottashed Cole et al. 1994). Few sites however have been systematically excavated. Kelly and Highley (1979), as part of the Jackpump Project, excavated 11 units at 41KA52 to expose two hearth features associated with Late Archaic and/or Late Prehistoric occupations. A Late Archaic human burial (41KA89) on the Haiduk property near Fall City was excavated by Huebner et al. (1996). Another Late Archaic burial and associated artifacts from this property had previously been documented, reported, and assigned state trinomial 41KA23 (Mitchell et al. 1984).

\section{KA26}

Site 41KA26, located at the junction of Cibolo Creek and FM 887, was originally recorded by Dan Scurlock in 1972. On the initial recording form the site is designated El Fuerte de Santa Cruz or Santa Cruz del Cibolo (Scurlock 1972). It is described as "the site of a Spanish Presidio that was established in the 1770s on an old Spanish road linking Goliad to San Antonio." The site description lists an old stone house and scattered artifacts and building stones on the west bank of the Cibolo Creek north of State Road 887. Included in his description of the features at 41KA26 are: an "early-nineteenth century stone house, [a] twentieth century smokehouse, [an] old road cut (crossing) on Cibolo Creek, [and an] outcrop of stone (quarry site)." His survey party observed "some" majolica and many nineteenth-century glass shards and ceramic sherds. No indication is given of why he felt this was the site of the Spanish fort.
In 1984, G. T. Goode conducted a systematic survey along the right-of-way at 41KA26 (M. G. Goode 1984). Here, four components of $41 \mathrm{KA} 26$ were identified:

1) 41KA26-A, a component on the west side of the creek south of FM 887 containing mid- to late nineteenth century materials. Area $\mathrm{A}$ is on a terrace overlooking Cibolo Creek and is thought to be the location described by Scurlock as containing the old stone house and the Spanish fort.

2) 41KA26-B, a component on the east side of the Cibolo immediately south of FM 887 thought to be a campsite for eighteenth-century Native American groups overlooking the Carvajal Crossing;

3) 41KA26-C, a discrete campsite $150 \mathrm{~m}$ north of Area B; and

4) 41KA26-D, the location of El Fuerte de Santa Cruz, $200 \mathrm{~m}$ north of the project area (Goode 1984).

Subsequently, two components of the site, 41KA26-A and $41 \mathrm{KA} 26-\mathrm{B}$, were selected for testing (Figure 3). Six 1-x-1-m units, one backhoe trench, and six shovel tests were excavated in the area on the west bank of the Cibolo, designated 41KA26-A. Mid-to latenineteenth century pottery and glass, four chert flakes, and several pieces of burned rock were recovered. No features or structures were found and the author felt the artifacts were from deposits previously disturbed by road construction (Goode 1984). Based on these findings, 41KA26-A was determined not eligible or suitable for further investigations.

At 41KA26-B, on the east side of the creek, 12 test units, and six shovel tests were excavated (Figure 3). These tests yielded unglazed Native American, Mexican majolica, and eighteenth- and nineteenthcentury ceramic sherds in addition to forged nails, animal bone, and lithics. The cultural material was recovered from the upper $40-60 \mathrm{~cm}$ of the test units. Analysis of the recovered artifacts suggested the cultural materials represented Native American occupation of the site during the eighteenth century, perhaps in association with the occupation of El Fuerte de Santa Cruz. It was based on these results, that the data recovery project reported here, was then conducted at 41KA26-B. 


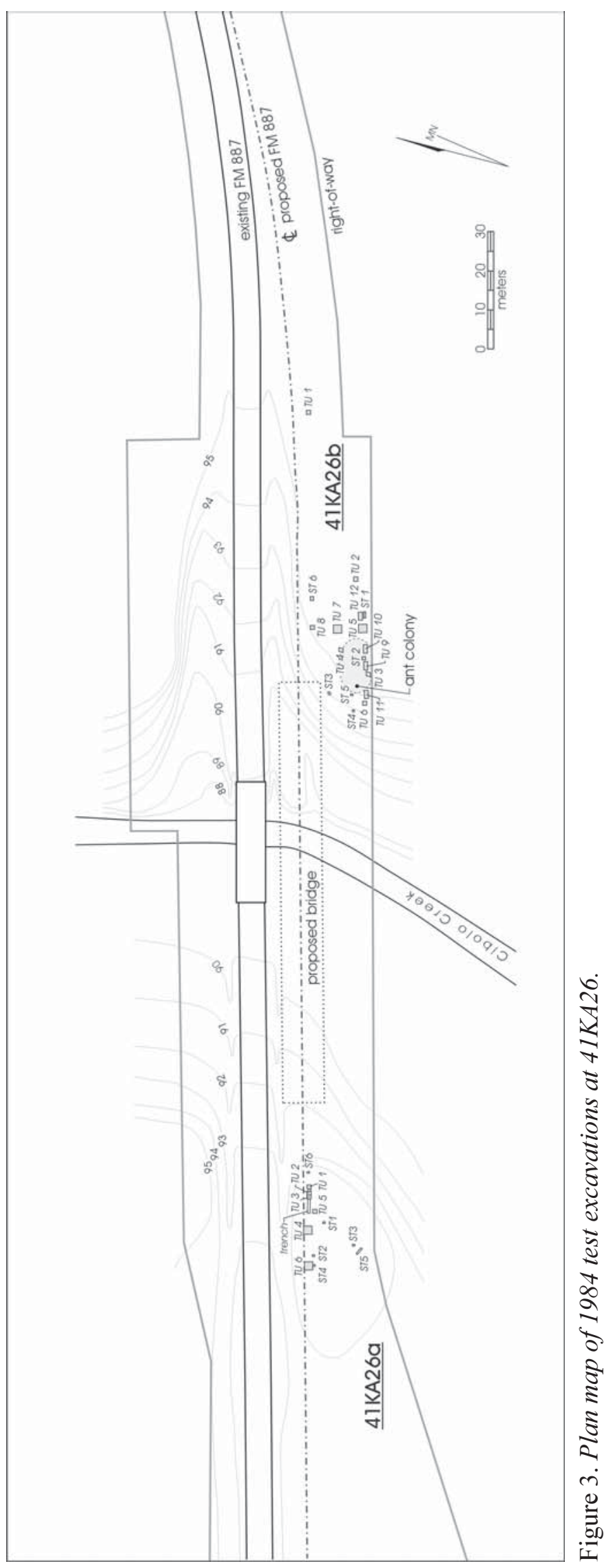


This page has been

redacted because it

contains restricted

information. 


\section{Chapter 5: Methodology}

Descriptions of the field, laboratory, and analytical methods used during the project are presented in this section. The field and laboratory work for 41KA26 was conducted by TxDOT in 1985 and is reconstructed here from TxDOT notes, forms, and illustrations.

\section{Field Methods}

The data recovery portion of the project was designed to mitigate the effect of bridge widening activities at 41KA26. Initial testing conducted in Area B (Goode 1984) on the east side of the creek, consisted of twelve test units and six shovel tests arbitrarily placed within the 80-x-24-m ROW south of FM 887. A possibly lateeighteenth century occupation zone was identified between $30-60 \mathrm{~cm}$ bs in these test units.

Based on information from the 1984 testing phase at the site (Goode 1984), a data recovery project was designed for Area B. Shovel tests (STs) 7-13, Test Units (TUs) 13-57, and Backhoe Trenches (BTs) 58 and 59 were placed within the ROW (Figure 4) to locate and define features, to identify the extent of the cultural deposit, and to maximize the recovery of the eighteenthcentury artifacts. Shovel tests ranged in size from 80 $\mathrm{x}-80 \mathrm{~cm}$ to $50-\mathrm{x}-150 \mathrm{~cm}$. They were excavated by shovel-shave and trowel technique and were labeled ST because the matrix was not screened. Test units were 1-x-1 m, 1-x-1.5 m, and 2-x-2 $\mathrm{m}$ in size. In most cases the upper $20 \mathrm{~cm}$ of the excavation units were not screened unless diagnostic artifacts were encountered in these upper levels. Although we can not be sure at this point, it appears this decision was made in the field based on information obtained during testing. All subsequent levels however, were excavated in $10-\mathrm{cm}$ levels and screened through $1 / 4$-inch hardware cloth. Horizontal control was established using the southeast corner of TU 5 as the center point (N0/W0) for the excavation grid. The excavation grid runs $30^{\circ}$ west of magnetic north. Units were given sequential numeric labels and the grid location of the SE corner of each unit was recorded. The $10-\mathrm{cm}$ vertical levels were given alphabetical labels, $A=0-10 \mathrm{~cm}$ bs, $B=10-20 \mathrm{~cm}$ bs, $\mathrm{C}=20-30 \mathrm{~cm}$ bs, etc. This system is used in this report.

Charcoal and fill from possible post holes was excavated as a block, wrapped in foil, and transported to the CAR laboratory for later analysis. Excavations were documented on standard TxDOT unit-level forms denoting depth below surface, soil description, artifacts collected, and general observations. Artifact bags were marked with provenience information and a lot identification number; this information was recorded in a lot-number log for cross-reference and accuracy. Selected units were profiled and plan maps were drawn of features. Color slides were taken to document the investigations.

\section{Laboratory Methods}

In the laboratory, artifacts were washed and air-dried. They were then sorted into gross artifact categories and recorded on Texas Highway Department Specimen Inventory sheets. Ceramic artifacts and other diagnostic pieces were labeled with India ink, which was covered with a clear sealant. In 1998, these artifacts were transported to the CAR laboratory where they were integrated into the existing database and prepared for analysis. Upon completion of analysis, artifacts were placed in acid-free boxes with acid-free labels for curation. All artifacts, documentation, field notes, maps, illustrations, and photographs were stored in accordance with the 1998 standards developed by the Texas Archeological Research Laboratory.

\section{Analytical Methods}

\section{Faunal and Ceramic Assemblages}

As discussed earlier, the original intent of this analysis was to combine the results from the excavation at 41KA26-B with excavations at 41RF1 conducted in 1999 to compare Colonial-period use of these two 


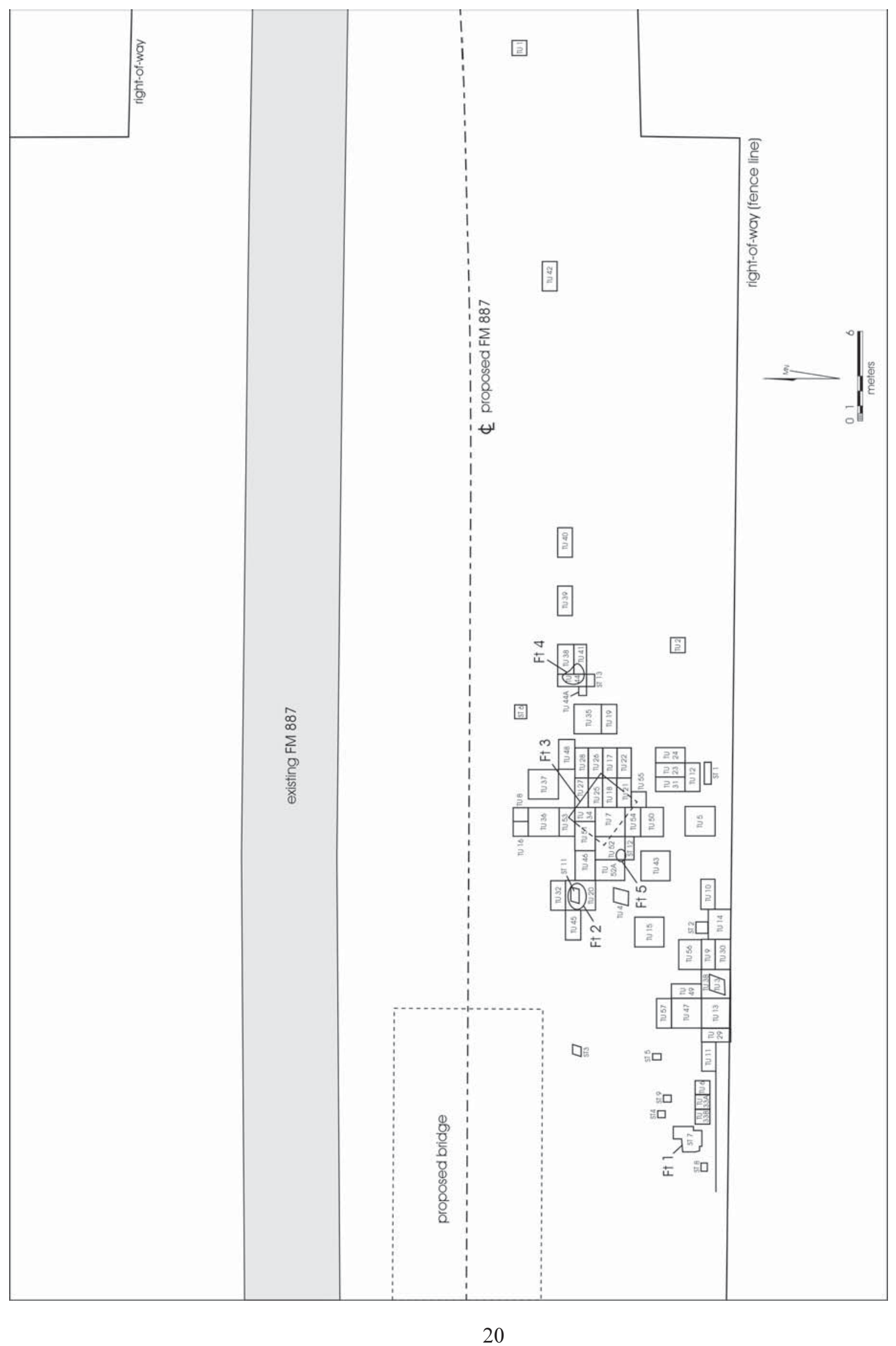

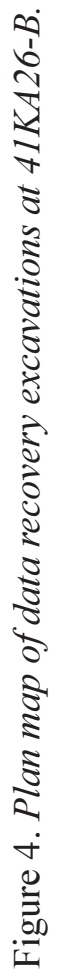




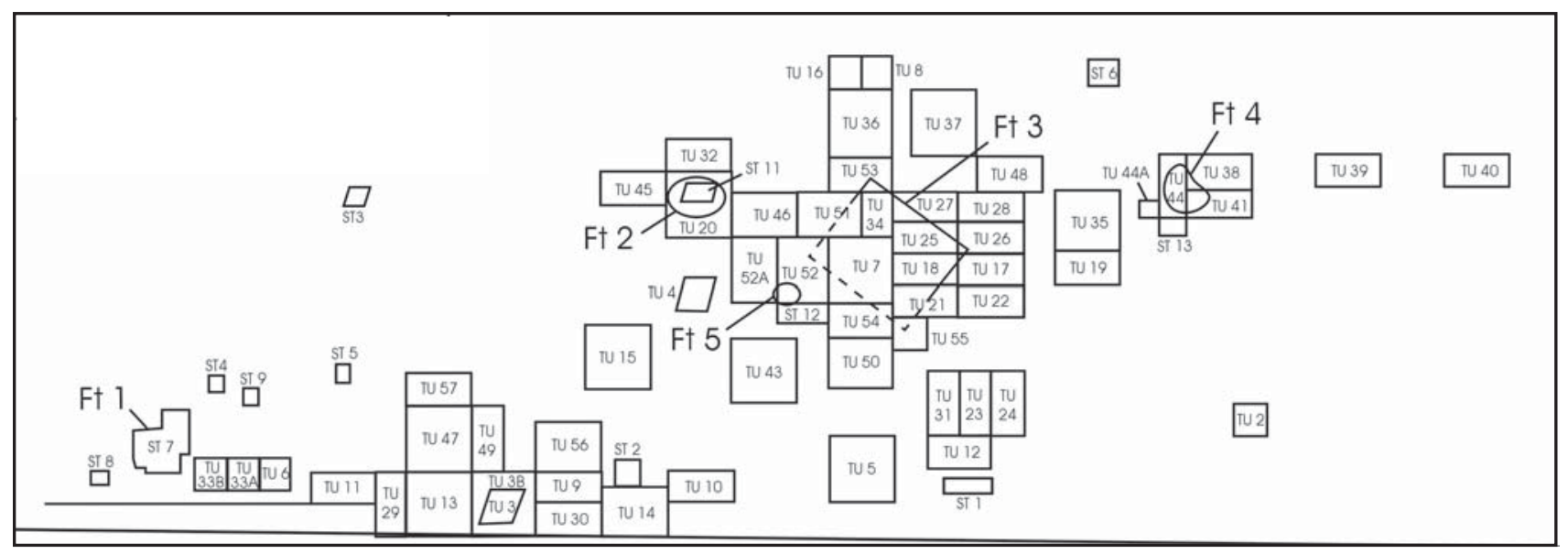

Figure 4a. Enlargement of main area of data recovery excavations at 41KA26-B (TUs 1 and 42 not indicated).

south Texas sites. The following analytical methods were designed with that purpose in mind, and although the plan to combine these reports was ultimately changed, the analytical methods remained the same.

Upon completion of cataloging and data entry, the faunal collection was shipped to Dr. Elizabeth J. Reitz at the Museum of Natural History at the University of Georgia for analysis. The ceramic assemblage was separated by type into two broad categories: Native American wares and Spanish-Colonial/European wares. Unglazed, bone and sand tempered sherds comprise the Native American collections, while the Spanish-Colonial/European wares included leadglazed, tin-glazed, burnished and decorated whitewares. The Native American wares were shipped to Timothy Perttula, Texas Archeological Research Laboratory, for in-depth analysis. The SpanishColonial/European wares remained at CAR for analysis by Anne Fox. As part of the ceramic analysis, 21 Native American sherds from 41KA26-B were selected for petrographic (thin-section) and Neutron Activation (INAA) analysis. The thin-section analysis was conducted by David Hill and the INAA analysis was conducted by Hector Neff and Michael Glascock at the Research Reactor Center at the University of Missouri. These analyses focus on changes and continuity in ceramic technology and the relative importance of local vs. imported (Mexican/European) ceramics to address questions concerning the effect of Spanish influence and the frontier supply system on Native American ceramic technologies.

\section{Macrobotanical}

Soil samples were not collected for macrobotanical analysis during excavation. However, charcoal and fill from possible postholes had been block excavated. Burned wood pieces from six of these possible postholes were sent to Phil Dering at Texas A\&M for species identification to aid in establishing the historic environmental character of this area (Table 2). 
Table 2. Wood Species Sample List

\begin{tabular}{|l|l|c|c|}
\hline Sample \# & Provenience & Item & Count \\
\hline SpID\# 1 & Feature 3 - 40-50 cmbd & Post "A" & 1 \\
\hline SpID\# 2 & Feature 3 - 40-50 cmbd & Post "B" & 1 \\
\hline SpID\# 3 & Feature 3 - 40-50 cmbd & Post "C" & 1 \\
\hline SpID\# 4 & Feature 3 - 40-50 cmbd & Post "D" & 1 \\
\hline SpID\# 5 & Feature 3 - 40-50 cmbd & Post (?) "L" & 1 \\
\hline SpID\# 6 & Feature 3 - 40-50 cmbd & Post (?) "H" & 1 \\
\hline
\end{tabular}

\section{Oxidizable Carbon Ratio (OCR) Dating}

The OCR dating procedure, a relatively new development in dating soils, has the potential to overcome the temporal limitations of standard radiocarbon dating encountered in Historic period sites. The OCR dating procedure measures the sitespecific rate of biodegradation of organic carbon, either as soil humic material or as charcoal. The biological recycling of organic carbon is fundamental to nearly all biological systems on the planet. While some forms of organic carbon, such as fresh organic matter, are quickly recycled, other more resistant forms, such as humus and charcoal, are recycled at a much slower rate. The effect of the biochemical degradation of charcoal and soil humic material is measured by a ratio of the total organic carbon to the readily oxidizable carbon in the soil sample. In general, as the total amount of organic carbon decreases though time due to recycling, the relative percentage of readily oxidizable carbon increases. This ratio is called Oxidizable Carbon Ratio, or OCR (Frink 1992, 1994). Three soil samples taken from the excavation blocks with the possible postholes at 41KA26-B were selected for OCR dating (Table 3).

Because OCR dating is based on site specific biodegradation, information on the geographic location of the site, mean temperatures, and average rainfall (Natural Fibers Information Center 1987) accompanied the soil sample. A general date of occupation between 1730 and 1830 was also supplied.

Table 3. Oxidizable Carbon Ratio (OCR) samples

\begin{tabular}{|l|l|l|l|l|}
\hline Sample \# & \multicolumn{2}{|l|}{ Provenience } & Soil & Weight \\
\hline \# 1- Post A & TU 21 & $40-50 \mathrm{cmbs}$ & sandy loam & $192.3 \mathrm{~g}$ \\
\hline \# 2 - Post B & TU 21 & $40-50 \mathrm{cmbs}$ & sandy loam & $215.9 \mathrm{~g}$ \\
\hline \# 3 - Post D & TU 18 & $40-50 \mathrm{cmbs}$ & sandy loam & $173.2 \mathrm{~g}$ \\
\hline
\end{tabular}




\section{Chapter 6: Results}

During the testing and mitigative phases of investigation at $41 \mathrm{KA} 26-\mathrm{B}$, an area measuring approximately $80-\mathrm{x}-15 \mathrm{~m}$ was intensively examined by TxDOT archaeologists and crew members. Fiftyseven units, varying in size from $1-\mathrm{x}-1 \mathrm{~m}$ to $2-\mathrm{x}-2 \mathrm{~m}$, and 13 shovel tests were excavated, resulting in the removal of approximately $83 \mathrm{~m}^{3}$ of soil (see Figure 4). Five features believed to be associated with lateeighteenth to mid-nineteenth century campsites along this section of Cibolo Creek were identified. The 2,554 artifacts recovered from 41KA26-B are listed by provenience in Appendix I. For the analyses below, these artifacts were divided into six broad typological categories which include: 1$)$ ceramics $(\mathrm{n}=849), 2)$ glass $(\mathrm{n}=212), 3)$ lithics $(\mathrm{n}=256), 4)$ personal ornaments $(\mathrm{n}=19), 5)$ fauna $(\mathrm{n}=1111)$, and 6) metal $(\mathrm{n}=78)$. In addition, over 10,000 mussel shell fragments were collected. Detailed analyses of the diagnostic artifact classes are presented later in this report.

\section{Site Integrity}

The profile of Test Unit 7 (Figure 5a) presents a representative view of the sequence of the natural stratigraphy present across the north and north central portions of the site. The soils within the upper 10-15 $\mathrm{cm}$ in this part of the site, the modern A horizon, consist of dark gray-brown loamy sand. This is followed by a 10-15-cm layer of lighter yellowish gray-brown silty sand. Although the artifact density within this upper $30-\mathrm{cm}$ zone is sparse, diagnostics including three 1837 Republic of Texas buttons, a ca. 1835 Green River knife, seven glass trade beads, and an assortment of lead rifle and pistol balls, suggest these layers relate to early- to mid-nineteenth century occupations.

Beginning 30-32 cm bs, another darker soil layer is present. This brown to grayish brown loamy sand layer may represent a paleosol, or earlier living surface. This layer, which continued to a depth of $50-60 \mathrm{~cm}$ bs, consistently produced the highest artifact densities. The artifacts consist of unglazed and lead-glazed ceramics, lithic debitage, and animal bone, forming a mid- to late-eighteenth century assemblage possibly associated with the Spanish Colonial fort, El Fuerte de Santa Cruz del Cibolo. With the exception of TUs 43 and 50, deposits within the light brown silty sand layer below $60 \mathrm{~cm}$ were sterile. The animal bone, lithics, and ceramics recovered from these two deeper units suggests these lower deposits may predate the Spanish occupation of the site.

However, as illustrated in the profiles of TUs 29, 13, $3 \mathrm{~B}$, and 9 (Figure $5 \mathrm{~b}$ ) in the southwest quadrant of the site, the deposits in this area of the site are mixed. In this block of units along the fence line (ROW), the top $10 \mathrm{~cm}$ of the deposit is composed of a light yellow, silty sand that represents the back dirt from a very large cut-ant mound shown in Figure 4. This layer is underlain by a $2-3 \mathrm{~cm}$ lens of brown humus which represents the truncated remnant of the modern $A$ horizon below the ant mound. Below this depth, the soil layers in this section of the site begin to correspond with those seen elsewhere. At 10-15 cm below the surface, a layer of yellowish brown silty sand begins and continues to a depth of $30-35 \mathrm{~cm}$. This layer corresponds roughly in soil type and color to the earlyto mid-nineteenth century deposits found in other parts of the site. Below this is a $15-20-\mathrm{cm}$ thick layer of

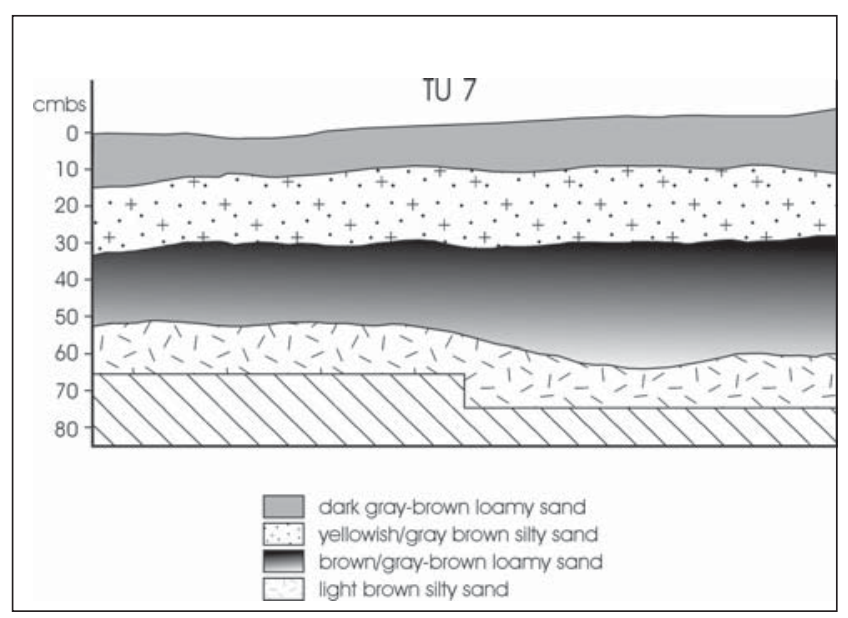

Figure 5a. East wall profile of TU 7. 


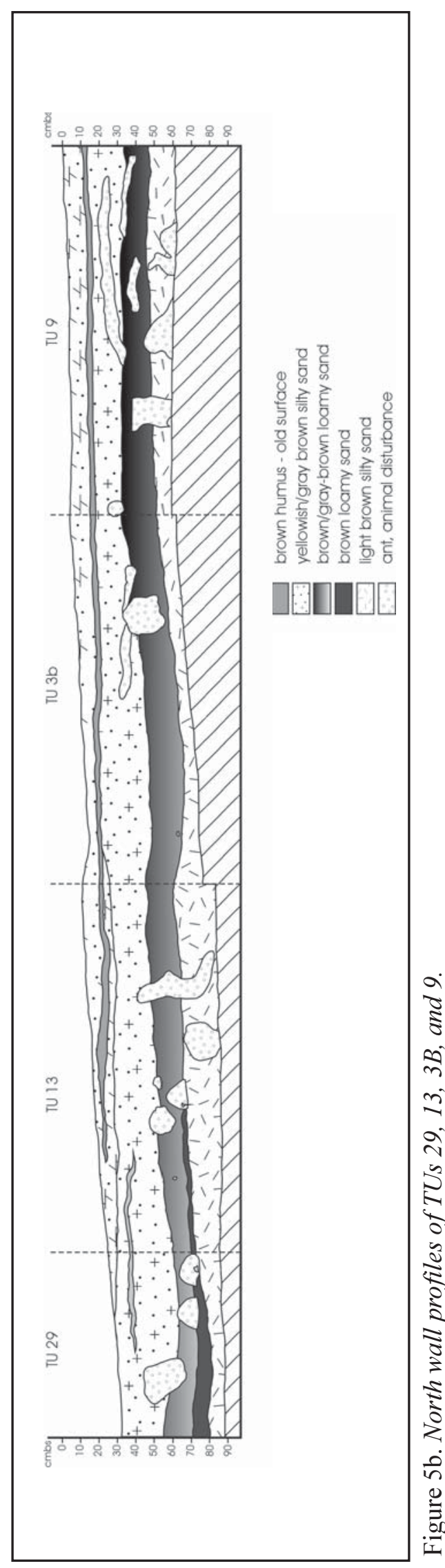

gray brown loamy sand that continues to a depth between $45-50 \mathrm{~cm}$ below the surface. This stratum is similar in depth and color to the mid- to late-eighteenth century layer paleosol. Below $50 \mathrm{~cm}$ the sterile, light brown sandy silt is present.

The disturbances caused by the ant and animal burrows illustrated in Figure 5b undoubtedly account for some of the vertical mixing of artifacts in the southwest quadrant of the site that is noted throughout the analytical sections of this report. Evidence of horizontal disturbance, possibly mechanical, in this portion of the site is also suggested by various horizontal artifact distribution maps and by breakage patterns detailed in the lithic section of the report. Fortunately, it appears that the deposits containing archaeological features, those in the north and north central portion of the site, maintain their stratigraphic integrity. However, while the artifacts recovered from units along the fence line are undoubtedly associated with others from this site, it appears they were recovered from horizontally and vertically mixed deposits.

\section{Feature Descriptions}

\section{Feature 1}

Feature 1 was encountered during excavation of Shovel Test 7 (see Figure 4). It consists of five pieces of sandstone in a soil matrix of gray brown loamy sand flecked with charcoal (Figure 6). The rocks were located less than $10 \mathrm{~cm} \mathrm{bs}$, with the top edge of one rock being less than $4 \mathrm{~cm}$ bs. The charcoal flecks were most numerous in a lens $10-12 \mathrm{~cm}$ bs but did not occur on or below the sandstone rocks. The rocks did not appear burned. Although the shovel test was enlarged no further evidence of sandstone or charcoal was found. The nearest natural sandstone outcrop occurs on a hill some distance to the west indicating their presence on the edge of this terrace probably resulted from some cultural activity. However, no other artifacts were recovered from Feature 1. 


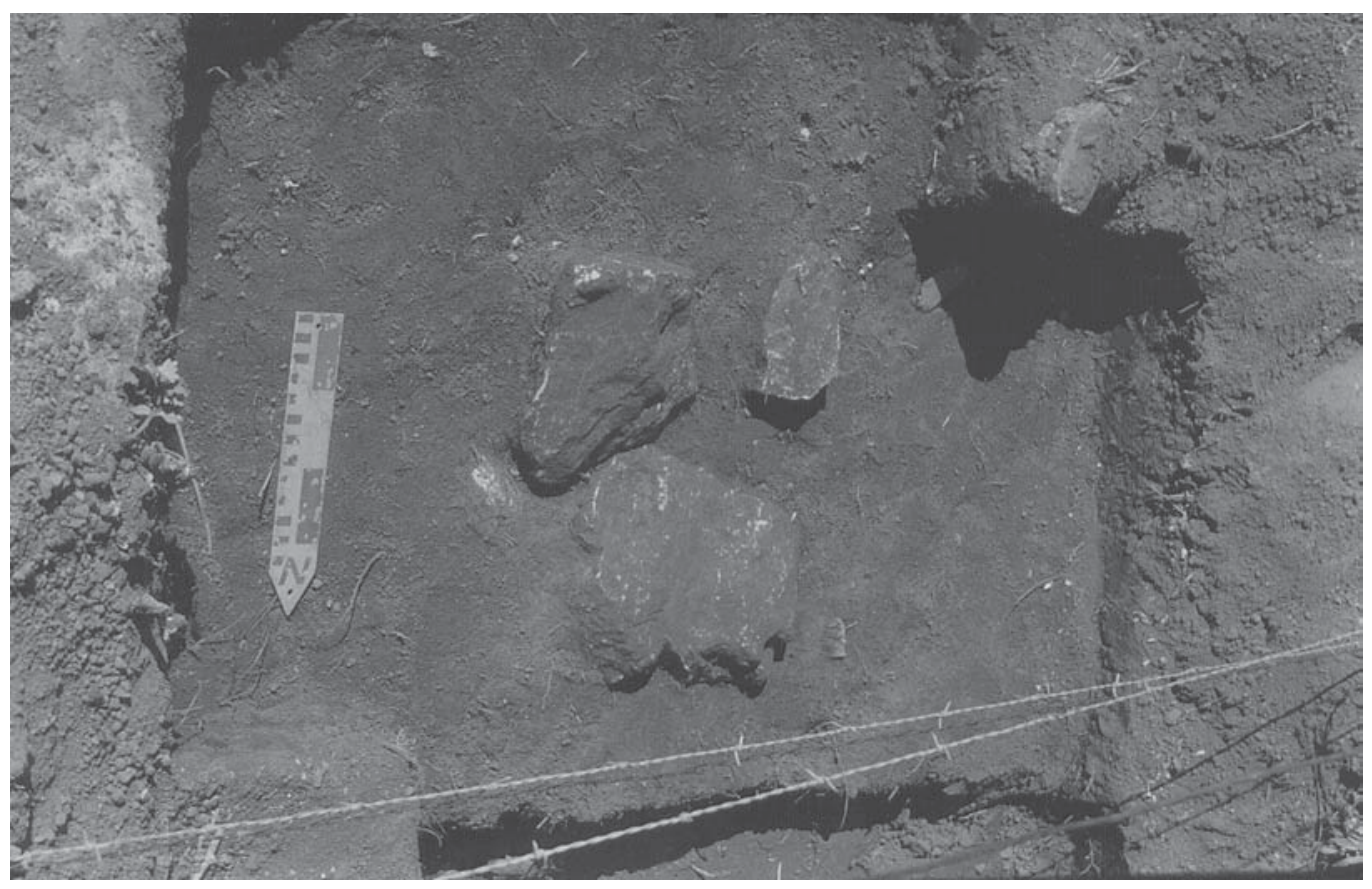

Figure 6. Feature 1.

\section{Feature 2}

During excavation of ST 11 (see Figure 4), a heavier and 45 were opened to further expose this than normal concentration of animal bone and Spanish lead-glazed ceramic sherds was recovered between 20-30 $\mathrm{cm}$ bs (Figure 7). Subsequently, TUs 20, 32, concentration. Numerous large-animal bones, cow or bison in size, were present throughout the upper 40 $\mathrm{cm}$ of these units with the heaviest concentration between $10-30 \mathrm{~cm}$ (Table 4).

Table 4. Vertical Distribution of Artifacts Associated with Feature 2

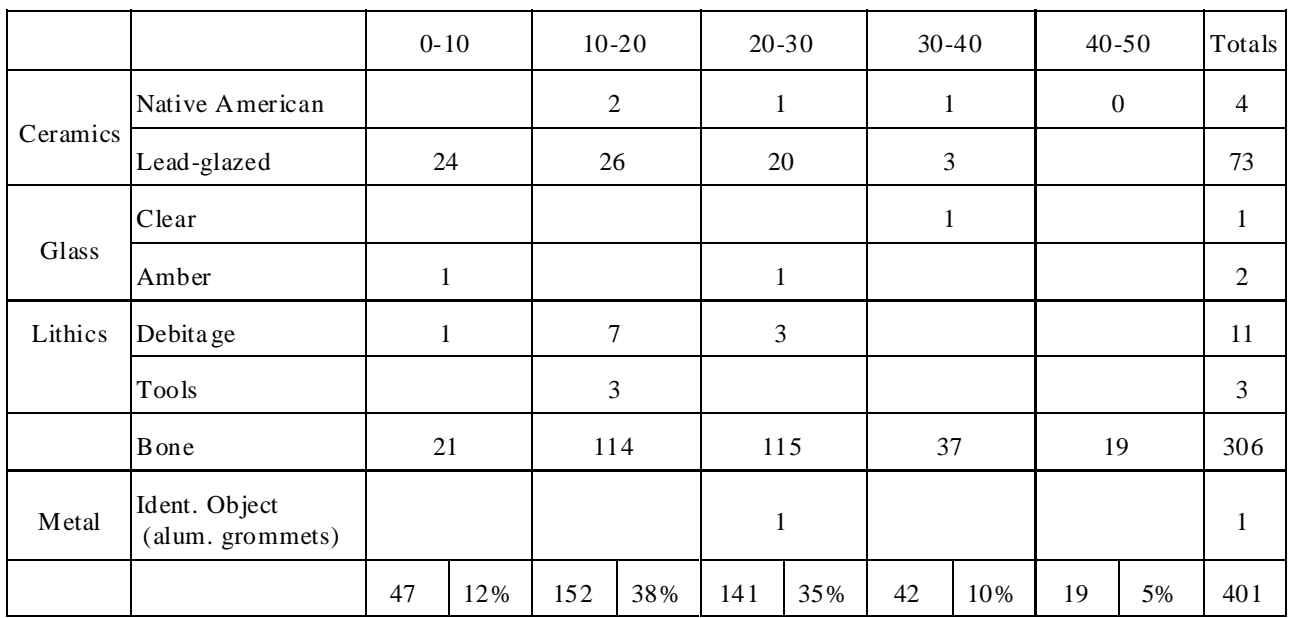




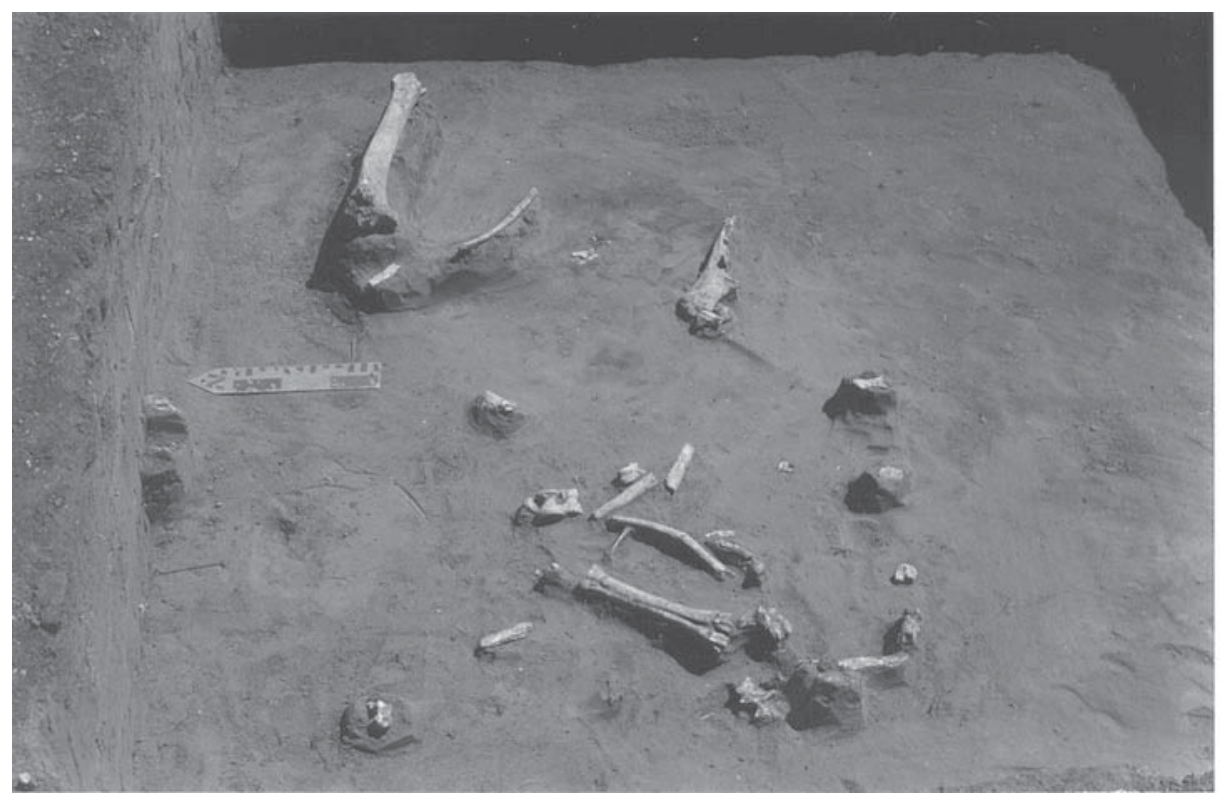

Figure 7. Feature 2.

In the field, a high incidence of foot and lower leg bones along with four maxillary teeth intact within a fragmented maxilla were noted. With the exception of the teeth and maxilla, none of the bones were articulated. Results of the faunal analysis (see PavaoZuckerman, Chapter 11) indicate that bison, cow, deer, and opossum remains constitute the faunal assemblage in Feature 2. Twenty-two percent of the site's MNI (minimum number of individuals) and all elements identified as probable bison in the assemblage came from Feature 2. No butchering marks were observed in the field or during analysis. The absence of edible meat parts suggested to the excavators that this accumulation represented a butchering disposal area where non-edible or low quality meat parts were discarded near the edge of the terrace. Although no evidence of a pit was observed during excavation, the lack of rodent remains in the Feature 2 faunal assemblage suggests the feature was a refuse pit that was not exposed for any length of time (see PavaoZuckerman, Chapter 11).
The heaviest concentration of ceramic sherds was also in the upper $30 \mathrm{~cm}$ of these units (Table 4). This assemblage includes four Native American sherds, two sandy paste and two small un-analyzed sherds (see Appendix II). The majority of the Feature 2 ceramic assemblage (95 percent) were lead-glazed sherds. These include 30 sandy-paste lead-glazed sherds, 29 Galera sherds, 13 unglazed non-native sherds, and 12 red-brown glazed sherds. Crossmended ceramic sherds from these feature-related units also indicate this feature is the result of a single depositional episode. As discussed in the Colonial Ceramic analysis portion of this report (see Chapter 7), lead-glazed ceramics are common throughout south Texas during the mideighteenth and early-nineteenth century Spanish Colonial period. Although these ceramics are not temporally diagnostic on a finer scale, their presence throughout the Feature 2 assemblage associates this faunal and ceramic concentration with Spanish/ Mexican use. Detailed descriptions of all artifacts are given later in this report and provenience information can be found in Appendix I. 


\section{Feature 3}

Feature 3 is the most intriguing of the features uncovered during this investigation. It appears to be the burned remnant of a "jacal" type structure constructed of vertical posts and clay daub. Graham (1978) describes jacales as a style of folk housing common in south Texas beginning in the middle of the eighteenth century. They are associated with earlier Mexican housing and were commonly built as temporary housing until more permanent structures were constructed. Occasionally they served as more permanent dwellings or outbuildings in areas of the state where construction materials were scarce or building funds were limited. The earlier versions of these structures were typically $8-10 \mathrm{ft}$ wide and $20 \mathrm{ft}$ long. The walls were constructed of a framework of sticks or posts that were tied together and plastered inside and out with mud mixed with lime or marl. The roof is typically made of thatch and the floors are packed dirt (Graham 1978).

Feature 3 is aligned in a northwest to southeast direction. The north and east walls of the Feature 3 structure are represented by an alignment of charred posts, charcoal, and burned clay exposed in the north central area of the site in TUs 17, 18, 25, 26, 27, 51, and 53 (see Figure 4). A linear pattern of charcoal flecks in TU 51 is described in the field notes as "forming a right angle" with the post alignment, thus representing the northwest corner of the structure. The "tops" of the posts, encountered between $32-35 \mathrm{~cm}$ bs, extended to a maximum depth of $50 \mathrm{~cm}$ bs while the linear charcoal stain in TU 51 was about $10 \mathrm{~cm}$ lower. In all, sixteen charred posts or post molds were uncovered, forming the outline of the north wall and portions of the west and east walls of the structure (Figure 8). The burned condition of the posts, and the linear pattern of charcoal flecks and patches of oxidized soil that make up the wall outline indicate this structure was destroyed by fire.

The posts range from $8-12 \mathrm{~cm}$ in diameter. The northeast section of the structure wall measures $4.2 \mathrm{~m}$ $(13.7 \mathrm{ft})$. The east wall section measures $2.4 \mathrm{~m}(7.8$ $\mathrm{ft}$ ). These measurements are slightly smaller than those identified as typical by Graham (1978). Although TUs 52,54 , and 55 were excavated adjacent the structure remnants, no evidence of the south wall was encountered. Goode (1984) suggests that evidence of the remaining portions of the west wall and all of the south wall may have been eroded when the small runoff channel illustrated in the profiles of TUs 46 and 51 (Figure 9) cut through the site. It is also possible that Feature 3 represents a three-sided structure, possibly constructed without a west wall to provide a better view of the creek crossing and to take advantage of prevailing breezes.

The structure posts were excavated into the brown to grayish brown loamy-sand paleosol containing the Colonial period deposit. Although it is not possible to determine how deep below the historic surface the structure posts were originally set, it is probable that the posts supporting this structure burned even with or a little below the ground surface when the structure was destroyed. If this is the case, the 20-30-cm level directly above the "tops" of the posts would represent the living surface at the time the jacal was destroyed, indicating the structure rested stratigraphically above the level of the Colonial period deposit.

Very few artifacts $(n=198)$ were recovered from the 15 units associated with or immediately adjacent the structure (Table 5). However, these artifacts combined with the OCR dates (see below) support the temporal interpretations made above and indicate the deposits in this portion of the site have stratigraphic integrity. An 1837 brass Republic of Texas Dragoons button (Albert 1969:251) and a post-1835 "Green River" butcher-knife blade (Peterson 1958) were found in the $20-30-\mathrm{cm}$ level immediately above the level of the "tops" of the posts. These artifacts are diagnostic of the early-nineteenth century and are within the deposit associated with the living surface of the jacal.

Sixty-one percent of the artifacts came from 30-50 $\mathrm{cm}$ below the surface. When animal bone (which accounts for 71 percent $[n=141]$ of the assemblage) is removed, 63 percent $(n=36)$ of the remaining artifacts were recovered from the $20-\mathrm{cm}$ thick deposit into which the structure posts were set. This small assemblage includes glazed and unglazed ceramic sherds, glass trade beads, lithic debitage and tools, and a very worn 1790 silver Spanish coin, all of which suggest a late-Colonial period time-frame of deposition for the artifacts beneath the jacal. 


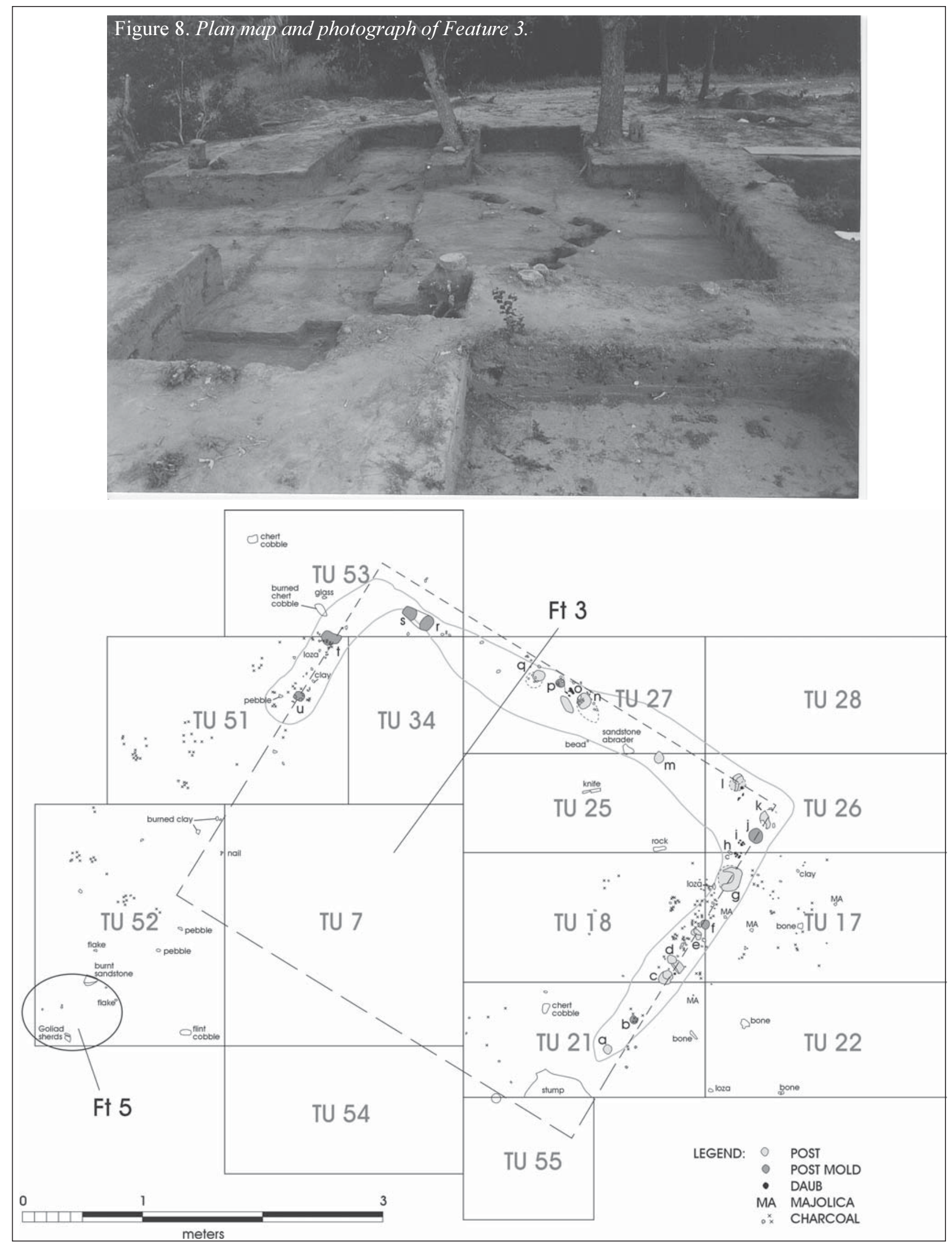




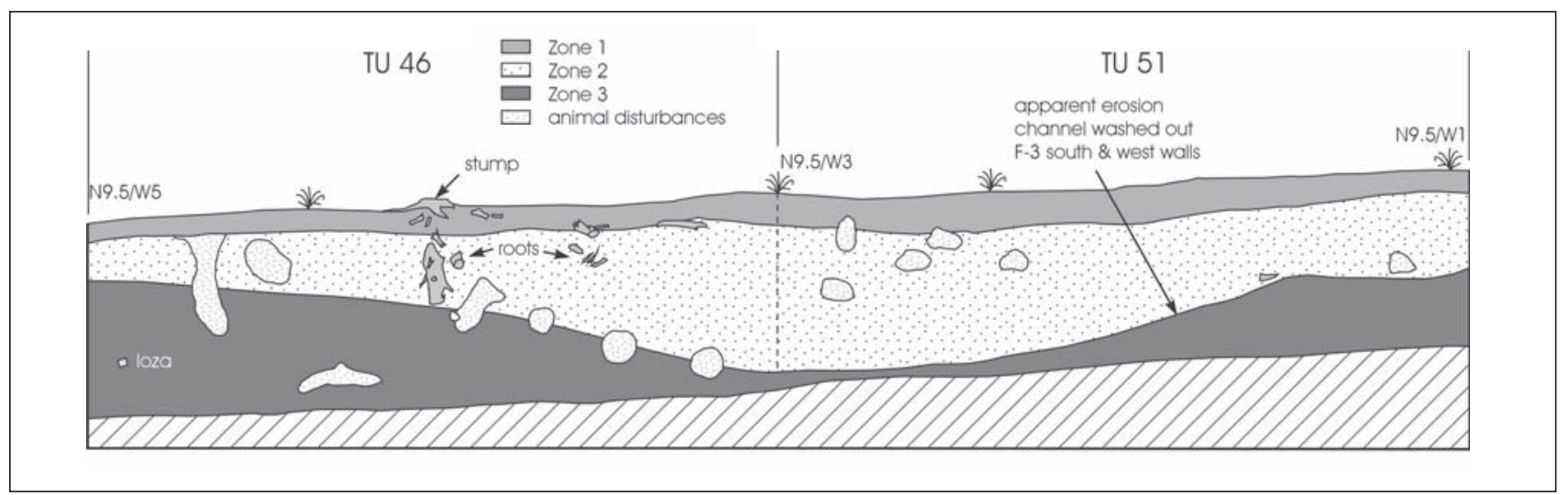

Figure 9. Profiles of TUs 46 and 51.

Table 5. Vertical Distribution of Artifacts Associated with Feature 3

\begin{tabular}{|c|c|c|c|c|c|c|c|c|c|c|c|c|c|c|c|c|}
\hline & & \multicolumn{2}{|c|}{$0-10$} & \multicolumn{2}{|c|}{$10-20$} & & & \multicolumn{2}{|c|}{$30-40$} & \multicolumn{2}{|c|}{$40-50$} & \multicolumn{2}{|c|}{$50-60$} & \multicolumn{2}{|c|}{$60-70$} & Total \\
\hline \multirow[b]{4}{*}{ Ceramics } & Native American & & & & & & & & 1 & & & & 1 & & & 3 \\
\hline & Tin-glazed & & & & & & & & 1 & & 2 & & & & & 3 \\
\hline & Lead-glazed & & & & & & & & 1 & & 2 & 2 & 2 & & & 5 \\
\hline & $\begin{array}{l}\text { Non-native } \\
\text { unglazed }\end{array}$ & & & & & & 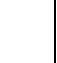 & & 2 & & 3 & & 1 & & & 9 \\
\hline \multirow[b]{2}{*}{ Glass } & Clear & & & & & & & & & & & & & & & 1 \\
\hline & Amber & & & & & & . & & 3 & & 1 & & & & & 5 \\
\hline \multirow[t]{3}{*}{ Lithics } & Debitage & & & & & & 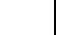 & & 9 & & 2 & 2 & 2 & & & 17 \\
\hline & Tools & & & & & & & & 3 & & & & & & & 3 \\
\hline & Bone & & 3 & & & & 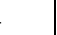 & & 32 & & 54 & 3 & 2 & & 6 & 141 \\
\hline \multirow[b]{2}{*}{ Ornament } & \begin{tabular}{|l} 
Button \\
(Tx Army)
\end{tabular} & & & & & & - & & & & & & & & & 1 \\
\hline & Bead & & & & & & & & 2 & & 2 & & & & & 5 \\
\hline \multirow{6}{*}{ Metal } & \begin{tabular}{|} 
Ident. Object \\
(.22 Lead bullet $)$
\end{tabular} & \multicolumn{2}{|c|}{1} & & & & & & & & & & & & & 1 \\
\hline & Fence Staple & & & & & & & & 1 & & & & & & & 1 \\
\hline & $\begin{array}{l}\text { Spanish coin } \\
(1790)\end{array}$ & & & & & & & \multicolumn{2}{|c|}{1} & & & & & & & 1 \\
\hline & Iron knife blade & & & & & \multicolumn{2}{|c|}{1} & & & & & & & & & 1 \\
\hline & Tin can & & & & & \multicolumn{2}{|c|}{1} & & & & & & & & & 1 \\
\hline & Totals & 4 & $2 \%$ & 1 & $1 \%$ & 16 & $8 \%$ & 56 & $28 \%$ & 66 & $33 \%$ & 38 & $19 \%$ & 17 & $9 \%$ & 198 \\
\hline Totals & without bone & 1 & $>1 \%$ & 1 & $>1 \%$ & 12 & $21 \%$ & 24 & $42 \%$ & 12 & $21 \%$ & 6 & $11 \%$ & 1 & $>1 \%$ & 57 \\
\hline
\end{tabular}


Samples of wood from six of the structure posts were sent to Phil Dering, Texas A\&M, for species identification. All of the samples were identified as mesquite, a building material readily available in this area. Since the charcoal associated with this structure is too recent for standard radiocarbon dating techniques, soil surrounding three of the structure posts was sent to Douglas Frink, OCR Carbon Dating, Inc., to determine if this method of dating would provide reliable dates for this and other historic-period sites. The dates returned from this analysis range from A.D. 1758-1786 (Table 6). When corrected by two standard deviations, the dates for the deposit into which the posts were set overlap in the early 1770s. In his analysis of the dates, Frink (1999) states that the soils associated with the posts represents organic material that predates the placement of the posts. Thus, the OCR age is probably somewhat earlier than the actual construction event (Frink 1999). This analysis is supported by the vertical distribution of diagnostic artifacts discussed previously.

During excavation, it was hypothesized that this structure may have been constructed and used by Native Americans, specifically the Apache, during the time the fort was occupied. However, based on the vertical distribution of the diagnostic artifacts associated with the structure and the OCR dates, it does not appear that this jacal structure was associated with the 1758-1786 occupation of the Spanish outpost, El Fuerte de Santa Cruz. It is most likely that the structure was constructed around the turn of the nineteenth century and may be associated with the 1830s Carvajal occupation and the 1840 s trading post established by George Rhymes near the crossing (Thonhoff 1964).

\section{Feature 4}

Feature 4 is an irregularly shaped concentration of charcoal, burned chert, and burned sandstone fragments identified in the field as the remnants of a large campfire. It was first revealed in one of the randomly placed 1-x-2-m units, TU 38 (see Figure 4). Subsequently, TUs 41,44 , and 44A were excavated to better explore this burned area, possibly to determine if it represented a burned-rock midden. Feature 4 covers an area approximately $2.45 \mathrm{~m}$ in diameter (Figure 10), with the densest concentration confined to an area roughly $1-\mathrm{x}-.70-\mathrm{m}$ in size. The heaviest concentration of charcoal and burned rock begins ca. $20 \mathrm{~cm}$ bs. The concentration of burned rock is slightly mounded in profile, sloping to $30-40 \mathrm{~cm}$ bs. According to the field notes, pieces of burned chert were the only artifacts within the feature. The other artifacts in these units (Table 7) were recovered from the periphery of the charcoal concentration.

After-the-fact interpretation of this feature is difficult. The charcoal and burned-rock concentration was encountered at $18-20 \mathrm{~cm}$ bs in the dark gray-brown loamy sand described as the modern A horizon elsewhere in the site. Ninety percent of the artifacts from units associated with Feature 4 were recovered from Level 3, 20-30 cm bs (Table 7). Although the collection of unglazed native sherds, Mexican majolica and lead-glazed sherds, chert flakes, and animal bone constitutes a common Colonial-period assemblage, it occurs within the layer of yellowish gray-brown silty sand associated with the early- to mid-nineteenth century occupation of the site. The presence of amber glass in Level 3 and road gravel and asphalt in Level 4 indicates a certain amount of vertical mixing occurred

Table 6. OCR Results from Feature 3

\begin{tabular}{|l|c|c|c|c|c|c|}
\hline Sample \# & Unit & $\begin{array}{c}\text { Depth } \\
\text { (cmbs) }\end{array}$ & $\begin{array}{c}\text { OCR } \\
\text { YBPTE }(1950)\end{array}$ & $\begin{array}{c}\text { Calendar Date } \\
\text { 1 STD }\end{array}$ & $\begin{array}{c}\text { Calendar Date } \\
\text { 2 STD }\end{array}$ & ACT \# \\
\hline$\# 1$ - Post A & TU 21 & $40-50$ & $187 \pm 5$ & A.D. $1758-1768$ & A.D. $1753-1773$ & 3686 \\
\hline$\# 2$ - Post B & TU 21 & $40-50$ & $173 \pm 5$ & A.D. $1772-1782$ & A. D. $1767-1787$ & 3687 \\
\hline$\# 3$ - Post D & TU 18 & $40-50$ & $169 \pm 5$ & A.D. $1776-1786$ & A. D. $1771-1791$ & 3688 \\
\hline
\end{tabular}




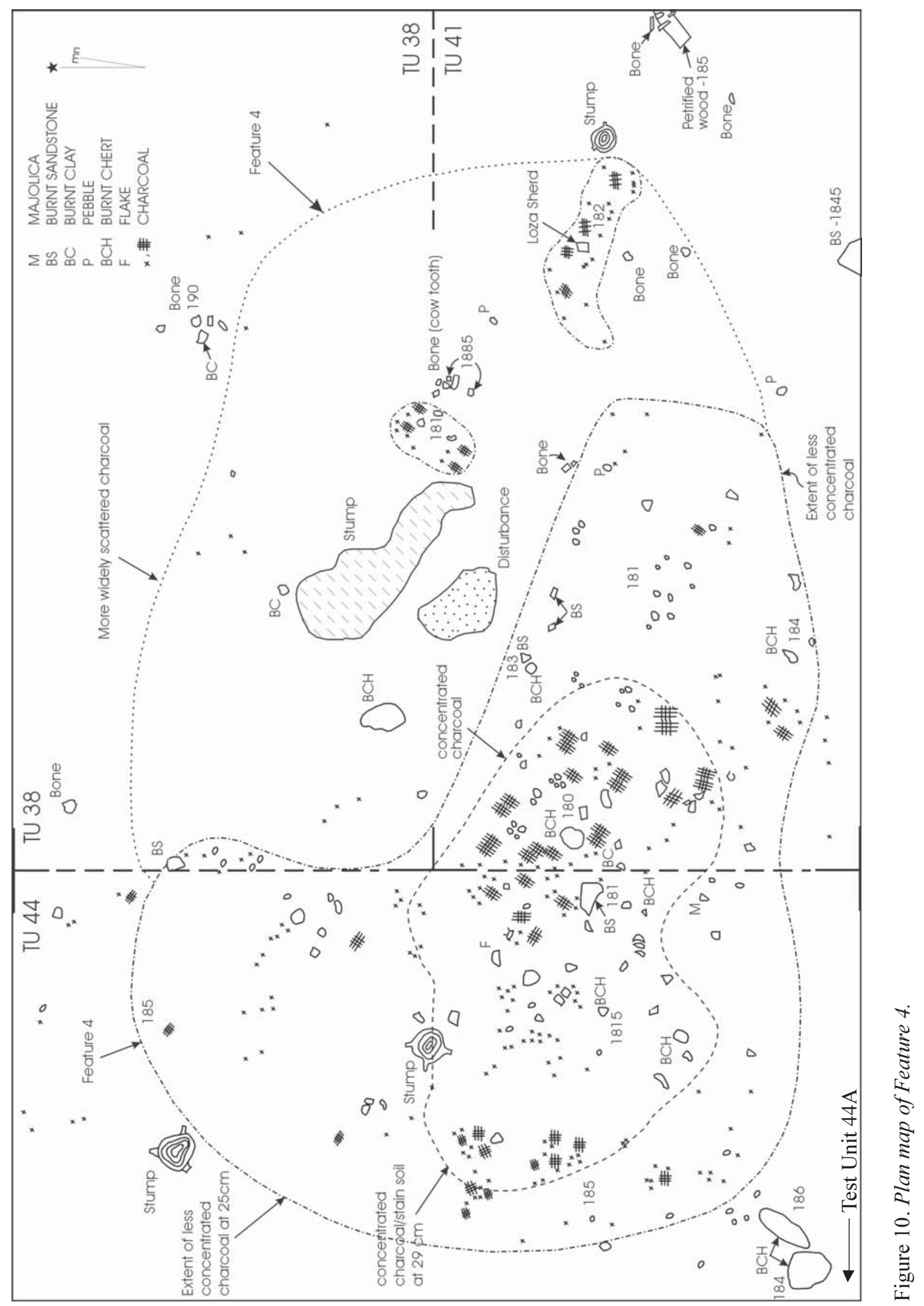


Table 7. Vertical Distribution of Artifacts from Units Associated with Feature 4

\begin{tabular}{|c|c|c|c|c|c|c|c|c|c|c|c|c|}
\hline & & \multicolumn{2}{|c|}{$0-10$} & \multicolumn{2}{|c|}{$10-20$} & \multicolumn{2}{|c|}{$20-30$} & & -40 & \multicolumn{2}{|c|}{$40-50$} & Totals \\
\hline \multirow{3}{*}{ Ceramics } & Native American & & & \multicolumn{2}{|c|}{2} & \multicolumn{2}{|c|}{14} & & 2 & \multicolumn{2}{|c|}{0} & 18 \\
\hline & Tin-glazed & & & \multicolumn{2}{|c|}{2} & \multicolumn{2}{|c|}{4} & & 1 & & 7 \\
\hline & Lead-glazed & & & & & \multicolumn{2}{|c|}{2} & & & & 2 \\
\hline Glass & Amber & & & & & \multicolumn{2}{|c|}{1} & & & & 1 \\
\hline \multirow[t]{3}{*}{ Lithics } & Debitage & & & & & \multicolumn{2}{|c|}{5} & & 2 & & 7 \\
\hline & Tools & & & & & & & & & 0 \\
\hline & Bone & & & \multicolumn{2}{|c|}{1} & \multicolumn{2}{|c|}{106} & & 4 & & 111 \\
\hline Metal & $\begin{array}{l}\text { Ident. Object (lead } \\
\text { bullet) }\end{array}$ & & & & & \multicolumn{2}{|c|}{1} & & & \multicolumn{3}{|c|}{1} \\
\hline \multirow[t]{2}{*}{ Construction } & gravel/asphalt & & & & & & & & 1 & & & 1 \\
\hline & & 0 & $0 \%$ & 5 & $3 \%$ & 133 & $90 \%$ & 10 & $7 \%$ & 0 & $0 \%$ & 148 \\
\hline
\end{tabular}

in this area of the site. The dearth of artifacts with this burned area ( $\mathrm{n}=37$ without bone), and their vertical distribution suggest a thin disturbed surface scatter possibly associated with the jacal. The widespread occurrence of charcoal in Feature 4 may actually be associated with the fire that destroyed Feature 3, located $7 \mathrm{~m}$ to the west.

\section{Feature 5}

Feature 5 is located approximately $1 \mathrm{~m}$ southwest of Feature 3 in the extreme SW corner of TU 52 which was excavated during the search for the west wall of Feature 3. It extends south into ST 12 and west into TU 52A (see Figure 4). Although TU 52 was initially excavated in an attempt to locate the west wall of Feature 3, aside from a slightly linear scatter of charcoal in the northern half of the unit, no evidence of the structure was present.

Feature 5 consists of two concentrations of potsherds (Figure 11). The larger concentration, "A," is made up of 37 sherds from two plain Native American bone-tempered jars or bowls (see Perttula, Chapter 9). Group "B" consists of five sherds from a nonnative unglazed earthenware bowl (Fox and Tennis, Chapter 7). Both of these concentrations were recovered from the same elevation, $40-50 \mathrm{~cm} \mathrm{bs}$, in the stratigraphic level associated with the Spanish Colonial period. Several other earthenware sherds were present that did not mend with these vessels.

One sandy-paste sherd not associated with the vessels (Special Sample \#201) and one bone-tempered body sherd from one of the vessels (Special Sample \#202) were among the 21 Native American ceramic sherds sent for INAA and petrographic analysis (see Neff and Glascock, Appendix V and Hill, Appendix VI). The chemical composition from the vessel fragment (\#202) was identified as coming from a raw material source zone in south central Texas and is among the most commonly observed paste group in the special sample. Although the chemical composition of the sandy-paste sherd (\#201) was slightly different from the regional materials, neither analysis could determine if this sherd represents an imported vessel or variability within the regional raw material. 


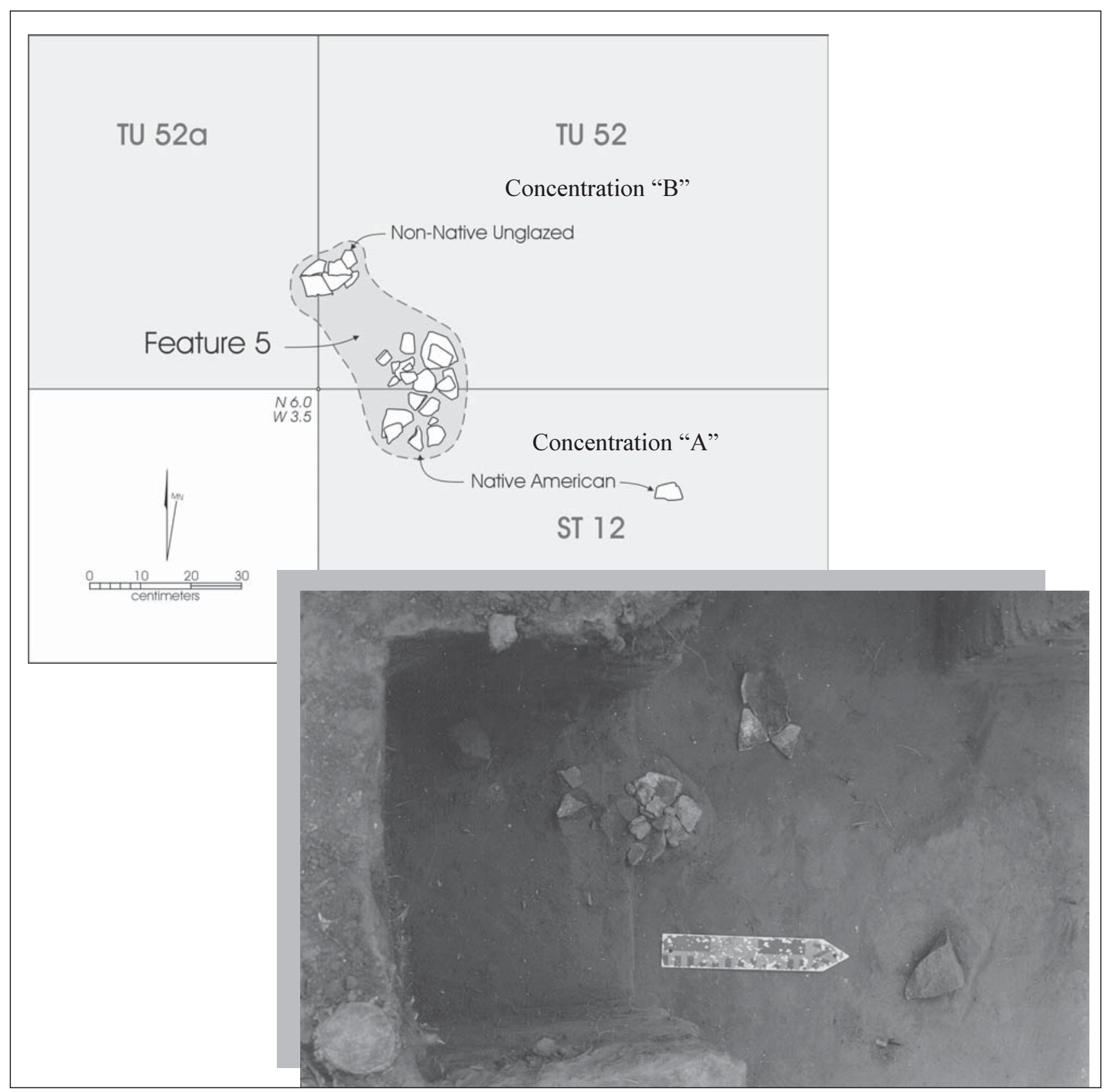

Figure 11. Plan map and photograph of Feature 5. 
Field notes indicate that no defined pit of any kind was associated with either of these ceramic groupings, but the stacked position of the sherds suggested to the excavators that at least a shallow depression helped preserve the tight groupings. They concluded that Feature 5 does not appear to represent a vessel cache as neither group contains sherds from a whole vessel. It is more likely that Feature 5 is a well-preserved dump of broken vessels. Other artifacts recovered from this level include lithics, animal bone, and one lead bullet (Table 8).

The only projectile point found during this investigation, a late Prehistoric-Historic period Cuney (Turner and Hester 1993) was recovered from TU 52A between $50-60 \mathrm{~cm}$ bs. One Native American ceramic sherd and one piece of lead-glazed ceramic were also recovered from this level. These artifacts are within the $30-60 \mathrm{~cm}$ bs Spanish Colonial stratigraphic layer and may represent a slightly earlier period of Colonial/ Native use of the site.

Table 8. Vertical Distribution of Artifacts from Units Associated with Feature 5

\begin{tabular}{|c|c|c|c|c|c|c|c|c|c|c|}
\hline & & \multicolumn{2}{|c|}{$20-30$} & \multicolumn{2}{|c|}{$30-40$} & \multicolumn{2}{|c|}{$40-50$} & \multicolumn{2}{|c|}{$50-60$} & Totals \\
\hline \multirow[b]{3}{*}{ Ceramics } & Native American & & & & & \multicolumn{2}{|c|}{37} & \multicolumn{2}{|c|}{1} & 41 \\
\hline & other unglazed & & & & & \multicolumn{2}{|c|}{5} & & 6 \\
\hline & Lead-glazed & & & & & \multicolumn{2}{|c|}{3} & \multicolumn{2}{|c|}{2} & 7 \\
\hline Glass & Clear & & & & & & & & & 5 \\
\hline \multirow[t]{3}{*}{ Lithics } & Debitage & & & & & \multicolumn{2}{|c|}{7} & \multicolumn{2}{|c|}{1} & 11 \\
\hline & Tools & & & & & \multicolumn{2}{|c|}{2} & \multicolumn{2}{|c|}{1} & 3 \\
\hline & Bone & & & \multicolumn{2}{|c|}{29} & \multicolumn{2}{|c|}{15} & \multicolumn{2}{|c|}{1} & 45 \\
\hline \multirow[b]{5}{*}{ Metal } & $\begin{array}{c}\text { Ident. Object } \\
\text { (Lead bullet) }\end{array}$ & & & & & \multicolumn{2}{|c|}{1} & & & 1 \\
\hline & Cut Nails & \multicolumn{2}{|c|}{1} & & & & & & & 1 \\
\hline & Wire Nails & \multicolumn{2}{|c|}{1} & & & & & & & 1 \\
\hline & Other (melted lead) & & & \multicolumn{2}{|c|}{1} & & & & & 1 \\
\hline & & 2 & $2 \%$ & 43 & $35 \%$ & 71 & $58 \%$ & 6 & $5 \%$ & 122 \\
\hline
\end{tabular}




\title{
Chapter 7: Colonial Ceramics
}

\author{
Anne A. Fox and Cynthia L. Tennis
}

In the following chapters, artifacts have been divided for analyses into Colonial period ceramics, other historic artifacts, Native ceramics, lithics, and faunal remains. Composition and temporal markers are discussed where possible for items in each of these classes. Patterns of vertical and horizontal distribution are investigated to identify temporal depositional components and to assess the stratigraphic integrity of the site.

\section{Colonial Period Ceramics}

Of the artifacts customarily recovered from Spanish Colonial sites, ceramics are usually the most useful, and sometimes the only items that can be utilized to date deposits and features. For this reason they tend to get more attention than other artifacts. Ceramics can be separated into types based on paste color, tempering material, surface treatment, and decoration. For this report, we have separated them according to their commonly accepted place of origin. The 404 unglazed, tin-glazed and lead-glazed varieties generally thought of as being made in Mexico, and European whiteware and porcelains are described here. Their horizontal and vertical proveniences are shown in Table 9. The unglazed ceramics $(n=445)$ attributed to local Indian groups are discussed in a separate section.

Tin- and lead-glazed ceramic wares were brought from Mexico to the Texas area by mule trains throughout the Colonial period. Unfortunately, the inventories of these shipments seldom mention much about the types of ceramics being carried, other than occasional references to tin-glazed wares which were evidently considered important enough to list. Beginning around 1800, English-made ceramics began to appear on Texas sites. Although importation of these wares was officially against the law, it appears that at least some of these wares were coming through Mexico. Humboldt (1941:IV:17) observed that during the last years of the eighteenth century, contraband was entering Mexico through Vera Cruz and Campeche causing the number of earthenware manufacturers in Puebla to decrease from 46 in 1793 to 16 in 1802. Archaeological investigations in San Antonio have suggested that during the early part of the nineteenth century illegal shipments were also coming into Texas through Matagorda Bay (Fox and Tennis 1995). These shipments probably accounted for the flood of English white earthenwares that suddenly appeared in the San Antonio area at that time. For this reason, they are included at the end of the Colonial ceramics descriptions.

\section{Lead-Glazed Wares}

As the name implies, lead-glazed ceramics have a thin coating of a lead-based glaze applied to the interior of the vessel before firing. Lead-glazed ceramics can be divided into sub-types based on paste types, wall thickness, and decoration. Three types of lead-glazed sherds were identified at this site.

The thick-walled variety has a sandy, tan-colored paste with a few brown inclusions. The color of the glaze generally appears yellow, but is actually the result of a clear or very pale green glaze overlying the pinkish $\tan$ body. When the paste is gray, the glaze appears green. This ceramic type is occasionally decorated with a green or brown band around the rim and center of the base. This thick-walled variety is wheel-made and is usually considered utility ware with bowls and ollas being the most commonly recovered vessel form. Sandy-paste lead-glazed wares were brought to Texas from Mexico throughout the Spanish Colonial period.

\section{Sandy-Paste Lead-Glaze}

The collection from 41KA26-B contains 130 sherds of the thick-walled, sandy-paste variety of lead-glazed ceramics. They were present in 27 of the units excavated at depths ranging from the surface to 70 $80 \mathrm{~cm}$ bs (Table 9). Nineteen of the sandy-paste ceramic fragments were rim sherds which represent 17 individual vessels (Table 10). Bowls account for 76 percent of the vessels present $(n=13)$. The diameters of the bowls range from $4-26 \mathrm{~cm}$. 
Table 9. Colonial Period Ceramics from 41KA26-B

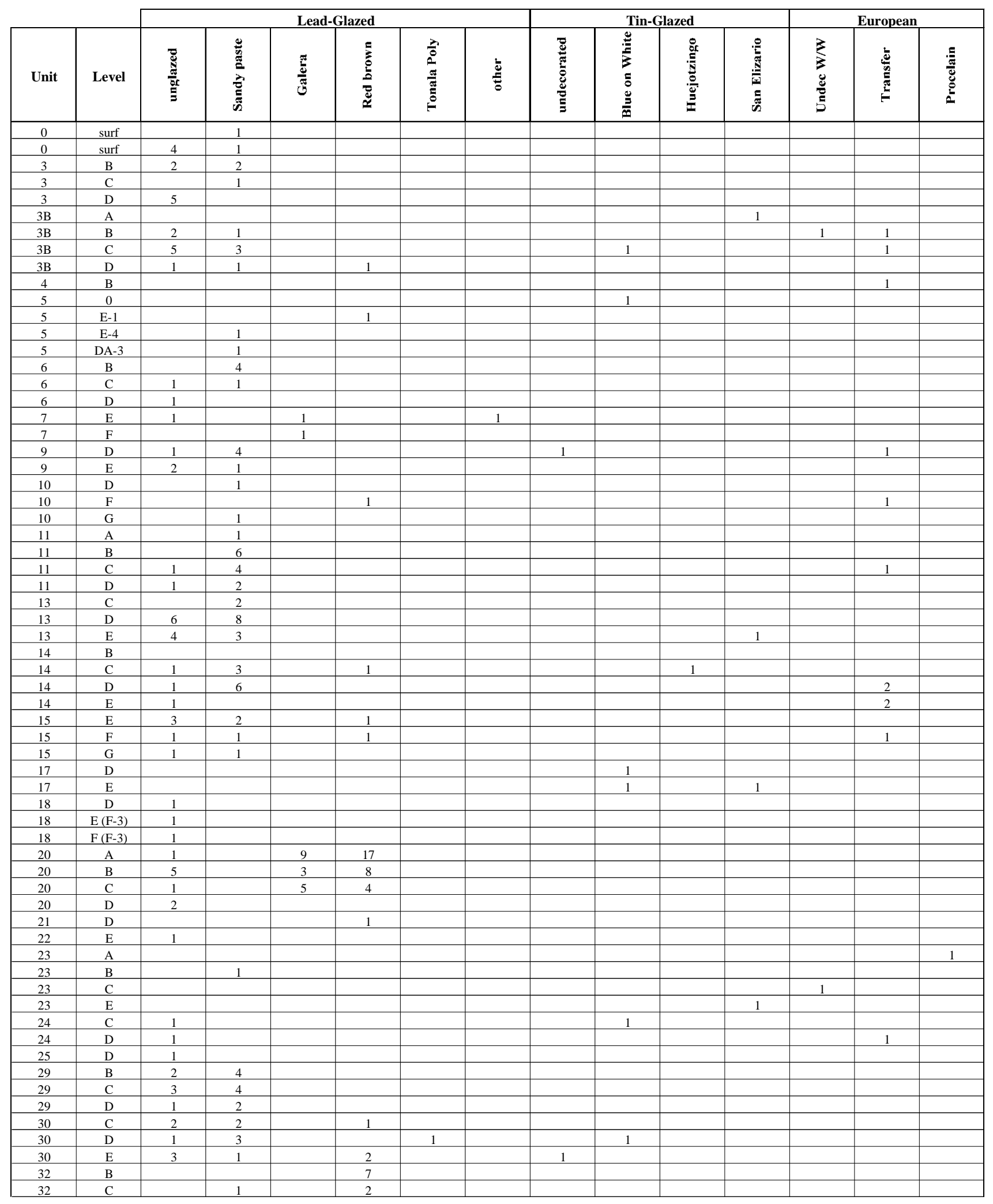


Table 9, continued...

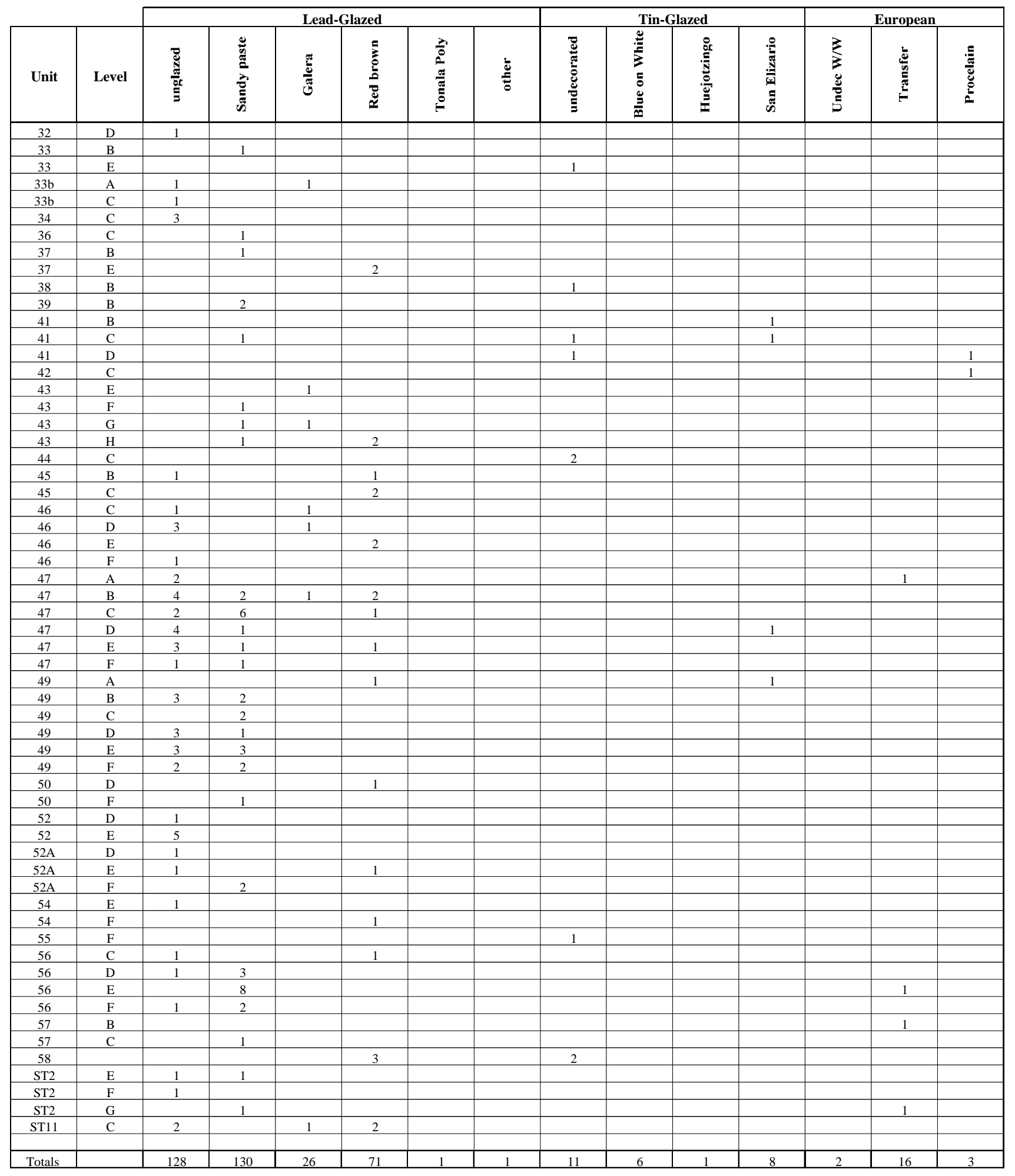


Table 10. Sandy-Paste Vessel Forms

\begin{tabular}{|c|c|c|c|c|c|c|c|}
\hline & & \multicolumn{2}{|c|}{ Bowls } & \multicolumn{4}{|c|}{ Jars } \\
\hline Unit & Level & Diameter $(\mathrm{cm})$ & Form & Unit & Level & Diameter $(\mathrm{cm})$ & Form \\
\hline 11 & $0-10$ & 11 & Bowl & 41 & $20-30$ & 9 & Jar \\
\hline 6 & $10-20$ & 14 & Bowl & $3 \mathrm{~B}$ & $30-40$ & 10 & Jar \\
\hline 29 & $10-20$ & 4 & Bowl & 29 & $20-30$ & too small & Jar \\
\hline 29 & $20-30$ & 12 & $\begin{array}{l}\text { Bowl (2 from same } \\
\text { vessel) }\end{array}$ & 56 & $30-40$ & 22 & Jar w/flared rim \\
\hline 32 & $20-30$ & 26 & Bowl & & & & \\
\hline 30 & $20-30$ & 10 & Bowl & & & & \\
\hline 10 & $30-40$ & 21 & Bowl & & & & \\
\hline 9 & $30-40$ & 18 & Bowl & & & & \\
\hline 56 & $40-50$ & 15 & $\begin{array}{l}\text { Bowl (2 from same } \\
\text { vessel) }\end{array}$ & & & & \\
\hline 56 & $50-60$ & 26 & shallow bowl/plate & & & & \\
\hline 49 & $40-50$ & 12 & Bowl & & & & \\
\hline 43 & $60-70$ & 12 & shallow bowl/plate & & & & \\
\hline 50 & $50-60$ & 20 & deep bowl & & & & \\
\hline
\end{tabular}

The majority of these bowls were probably all-purpose vessels while two can be classified as shallow soup bowls or plates. Four jars were represented by the four remaining rim sherds. The two jars listed in Table 10 with the 9- and $10-\mathrm{cm}$ diameter openings may have served to transport liquids. The jar with the $22 \mathrm{~cm}$ opening had a flared rim tapering to a constricted neck and was possibly used for water storage.

\section{Galera Ware}

The thinner-walled variety of lead glaze, called Galera, has a fine-textured, red-brown paste containing little or no sand temper. Decorations include dark brown and cream bands or dots and floral designs with occasional green accents. Schuetz (1969:50) suggested that this type of lead-glaze ware was made in Jalisco in western Mexico. Barnes (1980:96) states that goods from western Mexico began to compete with central Mexican goods during the reign of King Carlos III (1759-1788) when trading policies were liberalized, and that this type of ware appeared on the frontier after 1750 and continued to be used throughout the Colonial period. The vessels are mold-made, joined with thick shoulder seams and were used primarily as chocolate and bean pots/jars.

Twenty-six Galera sherds were recovered during the project. The majority of these sherds $(n=20)$ came from the upper $40 \mathrm{~cm}$ in units associated with the heavy animal bone and ceramic concentrations identified as Feature 2 (Figure 4). Two Galera sherds were found in Unit 7 between $40-60 \mathrm{~cm}$ below the surface, depths below the level identified as the living surface of the jacal structure, Feature 3, in this unit. Two sherds came 
from below $50 \mathrm{~cm}$ in Unit 43 and the remaining two came from the upper $20 \mathrm{~cm}$ in units in the southwest quadrant of the site. There are two Galera rim sherds found within this collection; both representing small jars with $3-\mathrm{cm}$ and $5-\mathrm{cm}$ diameter openings respectively.

\section{Red-brown Ware}

Sherds with a fine-textured red paste covered with a lead glaze that intensifies the mahogany red of the vessels are the third type of lead-glaze present at 41KA26-B. Schuetz (1969:51) called this type Guadalajara ware, suggesting that it came from that part of Mexico. Recently we have called this Red-brown Ware (Fox 1974:59) hesitating to ascribe it to a particular Mexican manufacturing location. No date other than the Spanish Colonial period has been established for this variety of lead-glaze which is usually present in small amounts at mission sites in and around San Antonio. Although no complete examples of this ware have been recovered to date, the numerous small fragments from other south central Texas Colonial period sites suggest this variety of lead glaze was used most often for very small bowls or jars that may have contained some type of ointment.

Seventy-one Red-brown sherds were recovered from 21 of the excavated units during the project. Over half $(n=46)$ came from units associated with Feature 2 (Figure $4)$. Vertically, the heaviest concentration occurs within the upper $30 \mathrm{~cm}(\mathrm{n}=53,75$ percent). Two rim sherds of Red-brown ware were identified. These represent one 12-cm diameter jar and one 11-cm diameter bowl.

Two other lead-glazed sherds complete this portion of the collection, one a Tonala Polychrome recovered from Unit 30, Level D (30-40 cm bs), the other an unidentified sherd classified as "other" from Unit 7, Level E (40-50 cm bs).

Lead-glazed sherds from three of the units comprising Feature 2, TUs 20, 32, and 46, were found to crossmend to form portions of four vessels (Figure 12). These crossmends serve to support the horizontal association of the units and material in Feature 2. The variations in depths (from 0-10 to $40-50 \mathrm{~cm} \mathrm{bs}$ ) of these sherds can be interpreted two ways. It may suggest a degree of post-depositional vertical disturbance has occurred in this area of the site, or that the materials in this feature are the result of a single depositional episode. As both the field description and the analysis of the faunal material of Feature 2 suggest this feature was a short-term refuse pit, the single-depositional-episode interpretation is the most likely.

\section{Majolicas}

Majolicas are lead-glazed earthenwares which have tin added to the glaze in order to create an opaque white or cream colored surface. The paste is fine grained and ranges in color from cream, to pink, to dark red. Mexican majolicas were exported to the

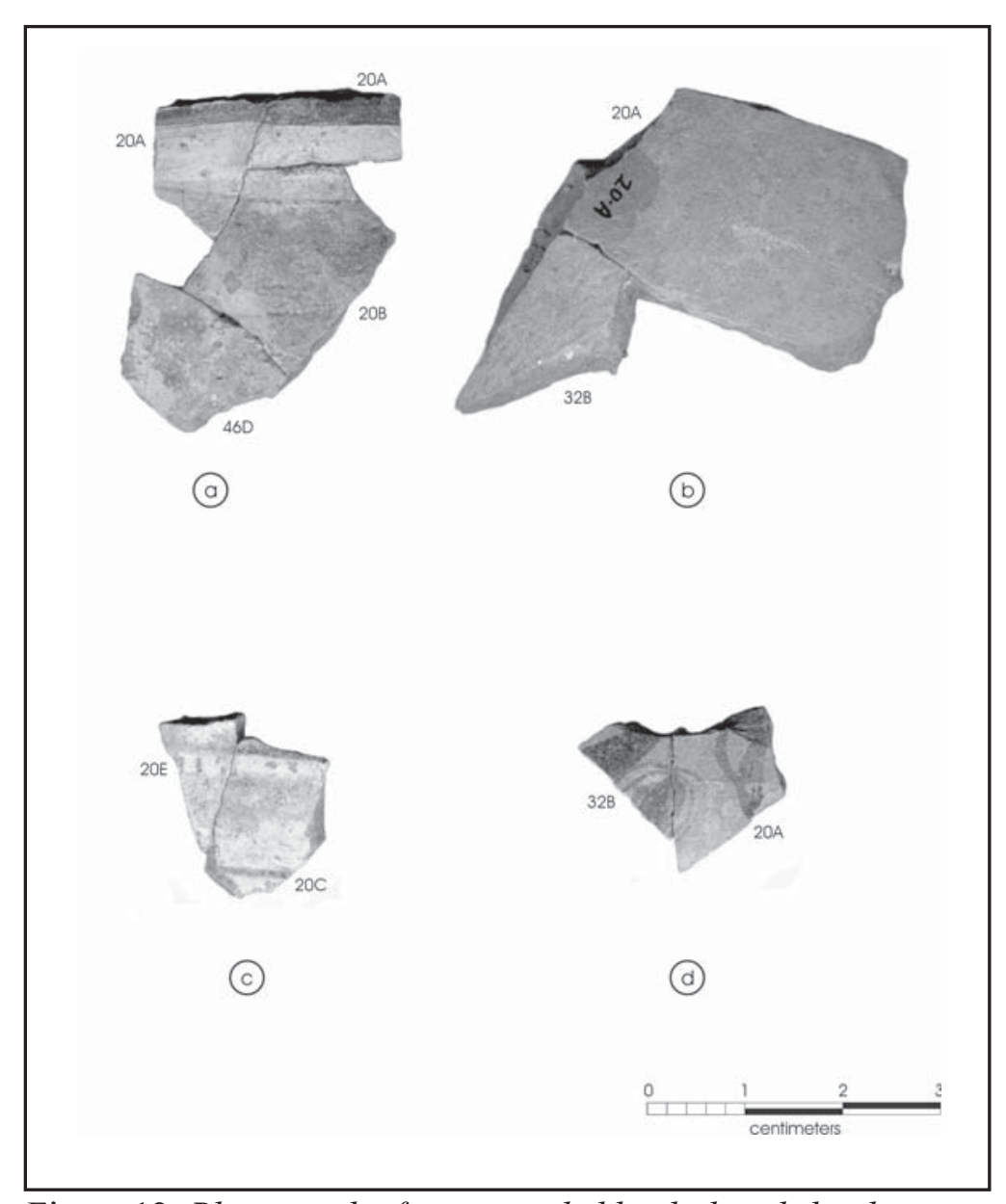

Figure 12. Photograph of crossmended lead-glazed sherds. 
northern Spanish frontier throughout the Spanish Colonial period and continued to be popular until early in the nineteenth century when European whitewares replaced them (Fox 1988; Gerald 1968; Goggin 1968; Tunnell 1966). The styles and colors of decoration on these wares changed periodically, making them particularly useful for dating sites or the deposits within them. Twenty-six majolica sherds were recovered during this project. Undecorated sherds $(n=11)$ make up 42 percent of the collection; the remaining decorated sherds include 6 pieces of Puebla Blue-on-White, 8 pieces of San Elizario (Table 11), and 1 piece of Huejotzingo described separately.

\section{Undecorated Majolicas}

These sherds can represent totally plain vessels, which were made throughout the eighteenth century (Lister and Lister 1974:30). They may also be from undecorated portions of decorated vessels.

\section{San Elizario}

In 1968, Rex Gerald proposed that a blue on white majolica design that includes accents of brown, narrow brown bands on either side of a blue rim band, and a large blue bird with brown legs and beak as a central motif be called San Elizario (Gerald 1968:45-52). Most commonly found on soup plates, this decoration is very common in late-eighteenth century Colonial deposits on sites in Texas (Carlson 1994:118; Ivey and Fox 1999:39) and was the most numerous decorated type found during these excavations. Only one small rim sherd of this type was recovered. It was too small to obtain an estimate of the vessel diameter, but it may represent a shallow bowl or soup plate.

\section{Puebla Blue-on-White}

This decorative type is described by Goggin (1968:190-194) as having varying shades of dark and light blue combined on a white background. Puebla Blue-on-White was manufactured from 1675-1830 (Deagan 1987:84) but was most popular in south Texas during the first half of the eighteenth century (Ivey and Fox 1999:39). No rim sherds of this type were recovered; however, the body sherds would seem to represent shallow bowls or plates.

\section{Huejotzingo Blue Banded}

Only one sherd of this type is present in this collection (TU 14, Level C, 20-30 cm). Vessels of this type have one blue band which extends over the rim. The blue can vary from dark blue to pale gray blue. There is seldom, if ever, a central design in addition to the rim band -meaning many of the undecorated majolica sherds are probably from vessels of this type. Huejotzingo Blue Banded majolica was made throughout the eighteenth century (Goggin 1968:195).

Table 11. Majolicas from 41KA26-B

\begin{tabular}{|c|c|c|c|c|c|c|c|c|}
\hline \multicolumn{3}{|c|}{ undecorated } & \multicolumn{3}{|c|}{ Blue on White } & \multicolumn{3}{|c|}{ San Elizario } \\
\hline Unit & Level & Count & Unit & Level & Count & Unit & Level & Count \\
\hline 58 & Surf & 2 & 5 & Surf & 1 & 49 & $0-10$ & 1 \\
\hline 38 & $10-20$ & 1 & $3 b$ & $20-30$ & 1 & $3 b$ & $0-10$ & 1 \\
\hline 41 & $20-30$ & 1 & 24 & $20-30$ & 1 & 41 & $10-20$ & 1 \\
\hline 44 & $20-30$ & 2 & 30 & $30-40$ & 1 & 41 & $20-30$ & 1 \\
\hline 9 & $30-40$ & 1 & 17 & $30-40$ & 1 & 47 & $30-40$ & 1 \\
\hline 41 & $30-40$ & 1 & 17 & $40-50$ & 1 & 13 & $40-50$ & 1 \\
\hline 33 & $40-50$ & 1 & & & & 17 & $40-50$ & 1 \\
\hline 30 & $40-50$ & 1 & & & & 23 & $40-50$ & 1 \\
\hline 55 & $50-60$ & 1 & & & & & & \\
\hline \multicolumn{2}{|c|}{ Totals } & 11 & & & 6 & & & 8 \\
\hline
\end{tabular}




\section{Unglazed, Untempered Wares}

One hundred twenty-eight unglazed sherds not attributed to Native American manufacture were recovered. Sherds of this type have not, to our knowledge, been previously documented on Spanish Colonial sites in south Texas. They differ markedly from the unglazed Native American ceramics because of their untempered, very fine-grained, tan-colored paste. They also lack the distinctive dark organic streaks in the center of the sherds that result from the low-temperature, open-air firing techniques used in the manufacture of Native ceramics. These sherds occasionally have black stripes or smudges on their exterior that appears to be a black slip rather than asphaltum. Examination of the sherds shows these unglazed vessels were hand-formed rather than wheel-thrown.

Unglazed sherds of this type were widespread both horizontally and vertically across much of the site with the heaviest concentrations present in Units 47, 49,3 , and $3 \mathrm{~B}$ in the southwest quadrant of the site (see Figure 4). Eleven rim sherds were present in this unglazed collection, 10 of which were large enough to assign vessel forms and/or measure. These sherds represent three jars, four bowls, two plates/ shallow bowls, and one plate (Table 12). These are traditionally Spanish and European vessel forms, further supporting the classification of this type as unglazed non-Native ceramics.

\section{European Earthenwares}

Refined wares attributed to European manufactures make up only five percent of the non-Native American ceramics recovered at $41 \mathrm{KA} 26-\mathrm{B}(\mathrm{n}=21)$. These wares are composed of highly fired, refined clays with vitreous glazes and various styles of decorations. As discussed earlier, European wares began to arrive in Texas around 1800. In this collection only three types are present: undecorated whiteware $(\mathrm{n}=2)$, transfer ware $(n=16)$, and porcelain $(n=3)$.

All of the transfer prints are deep blue in color and are line engraved, a technique which predates but overlaps stipple (ca. 1807) and was still being imported to Texas as late as ca. 1835 (Pollan et al. 1996:41). Based on design, they appear to be from only two vessels (Figure 13). The diagnostic whitish line (Figure $13 \mathrm{e}, \mathrm{f}$, and $\mathrm{g}$ ) is similar to the "frame" which appears in the "Chancellor Livingston" pattern manufactured by Enoch Wood \& Sons between 1818-1846. If this is the "Chancellor Livingston" pattern, it would date no earlier than 1816 when the Chancellor Livingston was built, but more likely to 1824 when the ship was used to transport the Committee of Welcome to greet Lafayette in New York Harbor. The ship was dismantled in 1834 (personnel communication with Sandra Pollan 1998; see also Arman and Arman 1977:Figure 220; Larsen 1975:Figure 47; Snyder and Bockol 1995:Figure 118).

Table 12. Unglazed Non-Native American Vessel Forms

\begin{tabular}{|l|l|l|l|l|l|l|l|}
\hline Unit & Level & Diameter $(\mathrm{cm})$ & Form & Unit & Level & Diameter (cm) & Form \\
\hline ST 2 & $40-50$ & $6 \mathrm{~cm}$ & Jar & 13 & $40-50$ & $18 \mathrm{~cm}$ & Bowl \\
\hline $3 \mathrm{~b}$ & $30-40$ & too small & Jar & 46 & $30-40$ & $15 \mathrm{~cm}$ & Bowl \\
\hline 47 & $40-50$ & $13 \mathrm{~cm}$ & Jar & 11 & $20-30$ & $28 \mathrm{~cm}$ & Plate or shallow bowl \\
\hline $52 \mathrm{~A}$ & $30-40$ & $7 \mathrm{~cm}$ & Bowl & 47 & $30-40$ & $15 \mathrm{~cm}$ & Plate or shallow bowl \\
\hline 52 & $40-50$ & $11 \mathrm{~cm}$ & Bowl & 35 & $20-30$ & $5 \mathrm{~cm}$ & Plate \\
\hline
\end{tabular}




\section{Horizontal and Vertical Distribution}

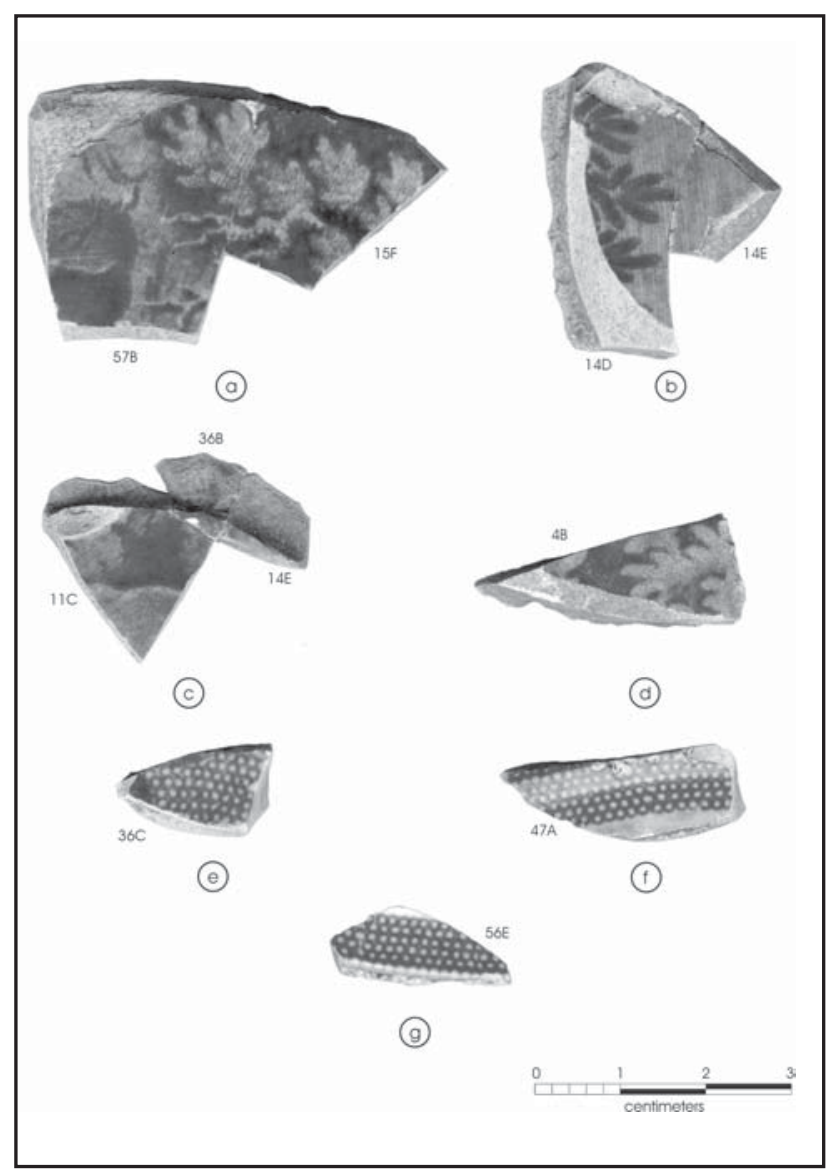

Figure 13. Crossmended transfer ware sherds.

The horizontal and vertical distribution of these distinctive transfer-decorated sherds is a strong indication of the extent of post-depositional disturbance occurring at 41KA26-B. The pieces illustrated in Figure 13 (a, b, and c) are sherds from a plate that crossmend from Units $3 \mathrm{~B}, 11,14,15$, and 57 in the southwest quadrant of the site (see Figure 4). They come from Levels B-F (10-60 cm bs). The sherds at the bottom of Figure 13 (d, e, f, and g) are from a lidded hollow-ware vessel recovered from Units $4,3 \mathrm{~B}, 47$, and 56 at depths ranging from $0-60 \mathrm{~cm}$ bs. It would appear that the upper $50-60 \mathrm{~cm}$ in the southwest quadrant of the site has been redistributed, perhaps during modern maintenance activities along this side of the road.
Two horizontal concentrations of Spanish and European ceramics are present at the site (Figure 14). Over 55 percent $(n=224)$ of the ceramics were recovered from 13 test units along the fence line in the southwest quadrant of the site. Sherd recovery ranged from 10-34 in these units and all ceramic types were represented. Another 20 percent $(n=82)$ were recovered from the three units and one shovel test associated with Feature 2, with 62 of these coming from the upper $30 \mathrm{~cm}$ in TU 20 and ST 11 . Unglazed non-Native wares and lead-glazed wares make up this concentration. The remaining 24 percent $(n=97)$ were distributed across the site with no more than nine sherds coming from any one unit.

As seen in Figure 15, the overall assemblage of Spanish and European ceramic sherds reflects a pattern of normal vertical distribution. However, this pattern is dictated by the vertical distribution of the two largest types in this assemblage, lead-glazes and unglazed non-Native sherds. When viewed independently, a slight difference in frequency by depth is apparent. Lead-glazed ceramic frequencies are higher in the upper levels with 58.5 percent $(n=134)$ of this type occurring in the upper $30 \mathrm{~cm}$ across the site and a peak of 23 percent $(n=53)$ occurring $20-30 \mathrm{~cm}$ bs. The frequencies of unglazed non-Native wares has a peak of 29 percent $(n=37)$ between $30-40 \mathrm{~cm}$ bs and 52 percent $(n=67)$ of this type was recovered between $30-50 \mathrm{~cm}$. Despite the substantial amount of overlap in the vertical distribution of these two types, the variations in frequency peaks indicates a depositional difference between the upper $(0-30 \mathrm{~cm})$ and lower (below $30 \mathrm{~cm}$ ) levels and suggests the non-Native unglazed sherds tend to predate the use of lead-glazed wares at the site.

The sample size of tin-glazed $(\mathrm{n}=26)$ and European wares $(n=21)$ is small which limits their spatial analytical value. Temporally, the time frame for the types of majolica at this site covers the entire eighteenth and early part of the nineteenth century and therefore offers little clue to the age or integrity of the deposits in which they occur. However, the presence of the ca. 1820 transfer pattern in the lower levels (40$70 \mathrm{~cm}$ ) of units along the southwest fence line strongly suggests mixing of the deposits in this area of the site. 


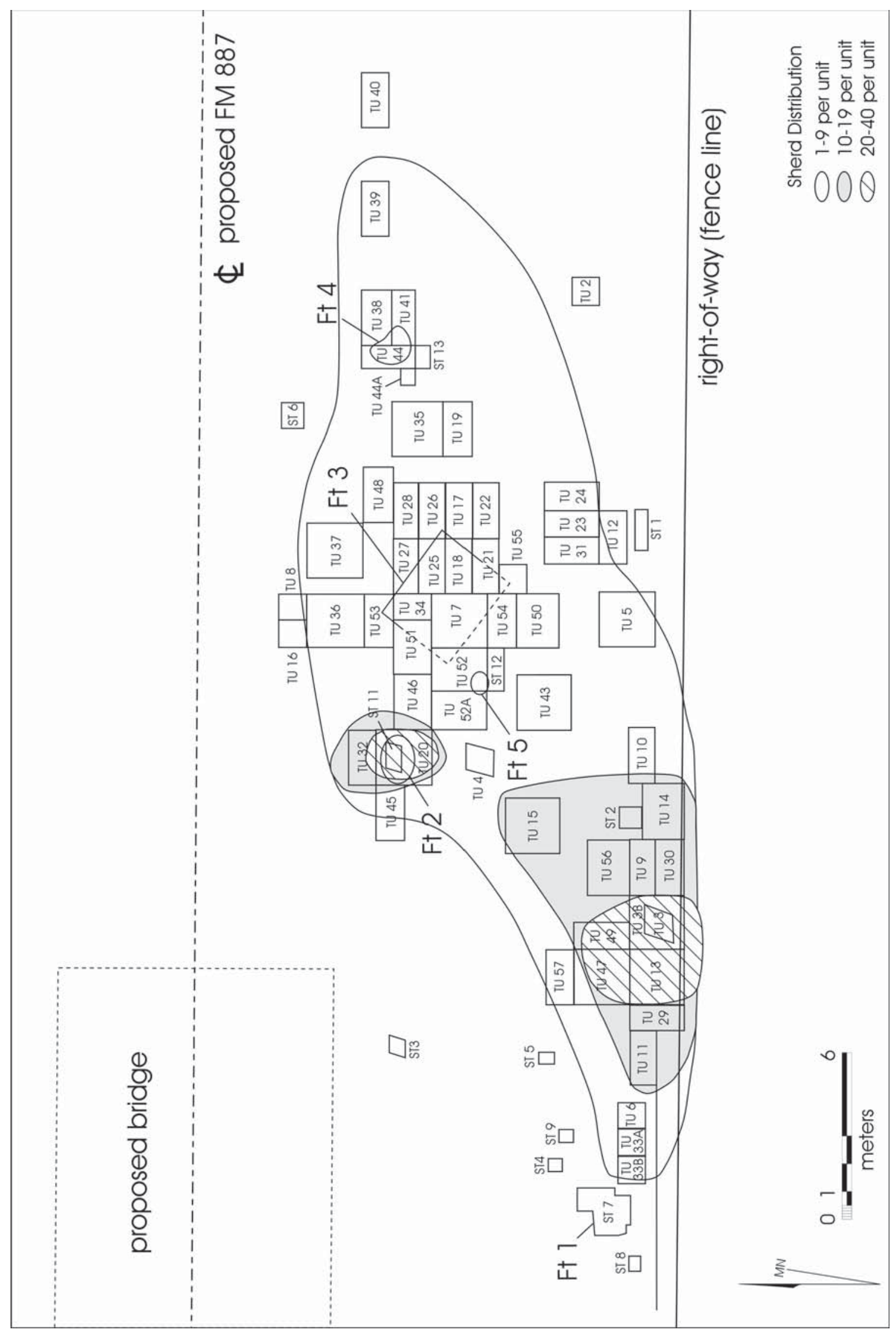

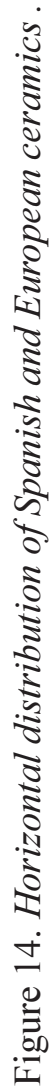




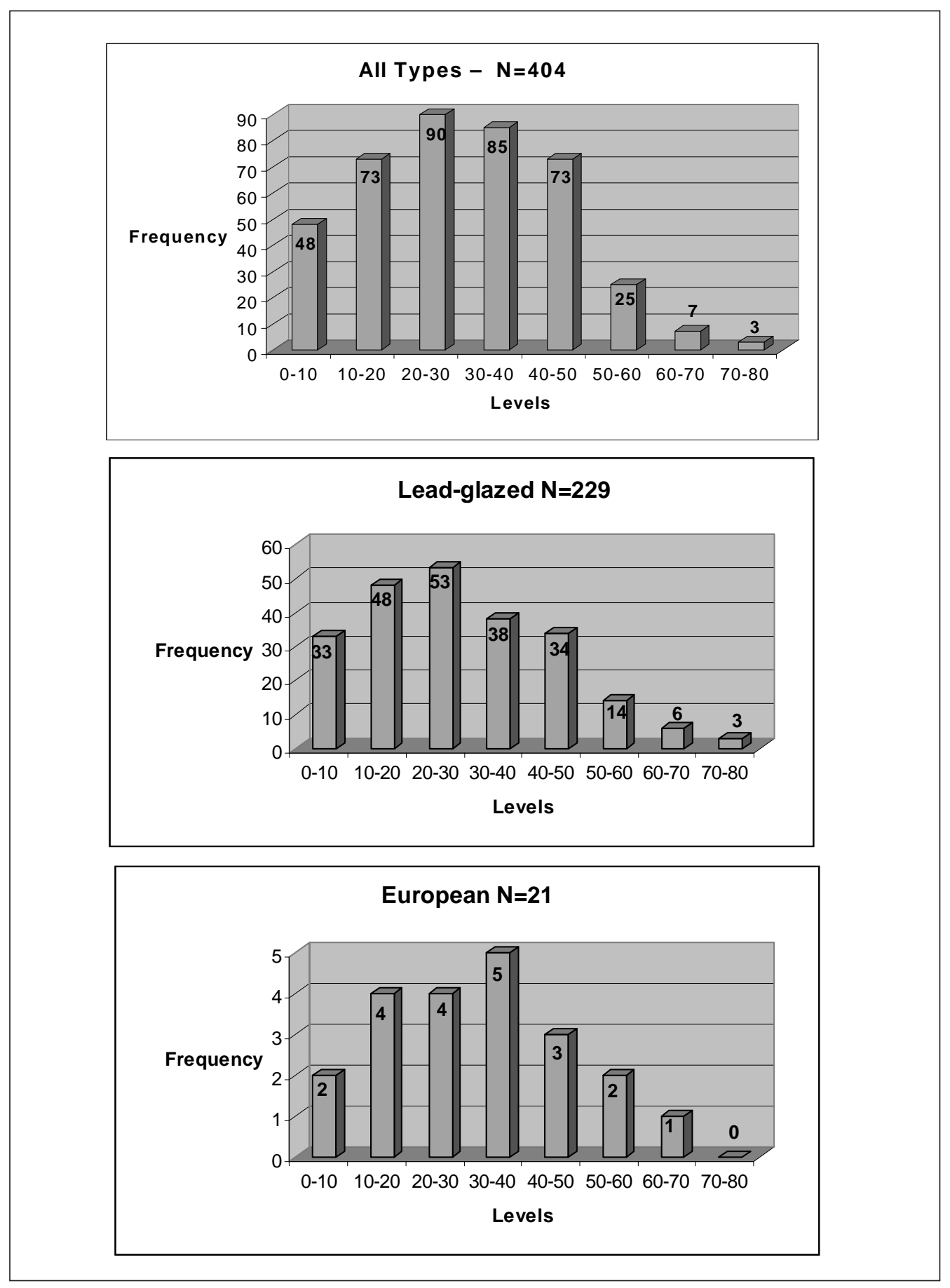

Figure 15. Frequency of Spanish and European ceramic types by level. 
Figure 15, continued...
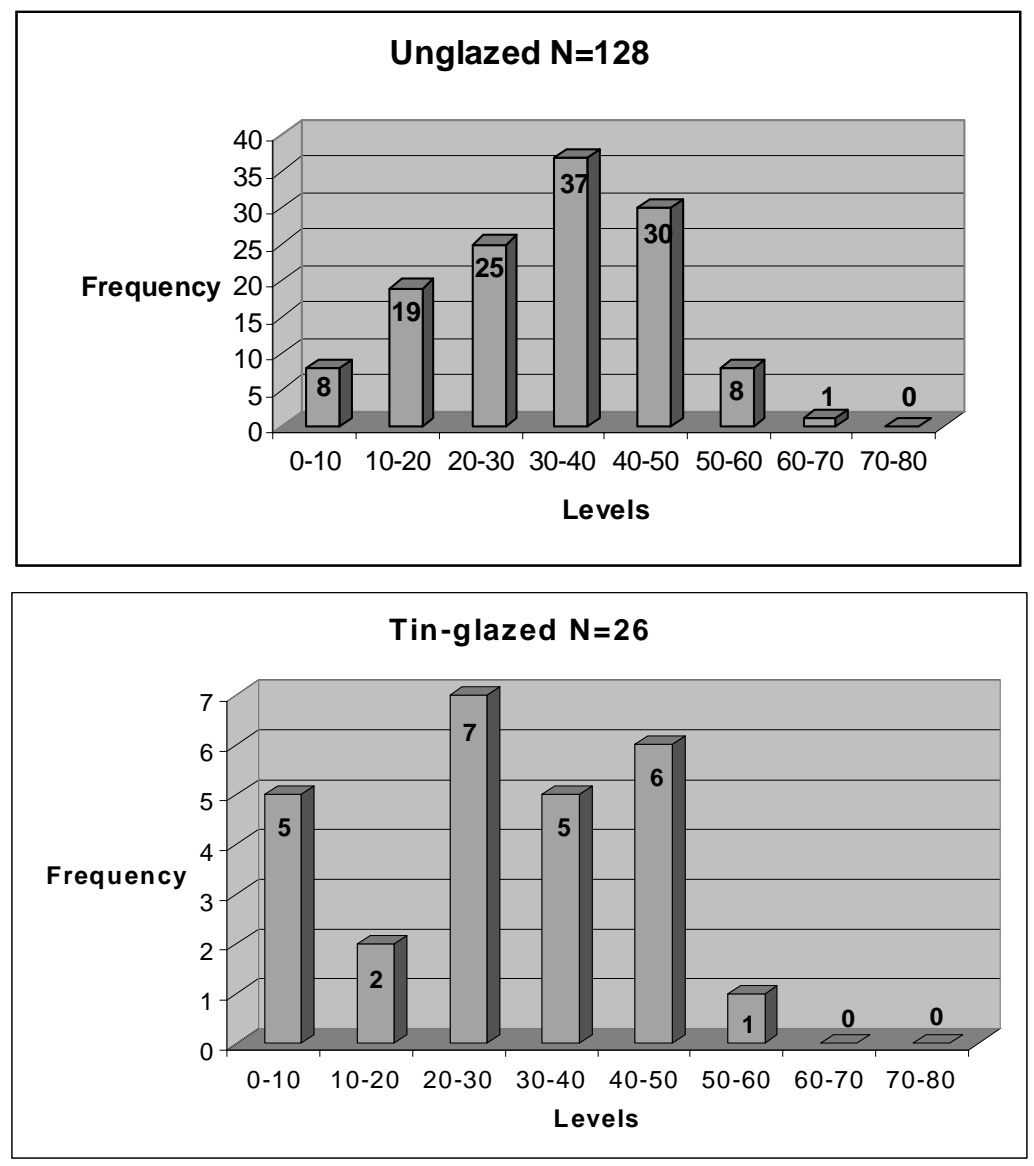



\section{Chapter 8: Other Historic Artifacts}

\section{Owen Ford and Anne A. Fox}

\section{Glass}

A total of 210 glass fragments and two complete bottles were collected from 41KA26-B. Identification of the samples utilized glass color and manufacturing techniques. Appendix I lists all artifacts, including glass, recovered during this project.

The clear glass section of Appendix I has been further defined here into three distinct categories: manganese bleached, selenium bleached, and hand-blown pontil. Two fragments of manganese bleached glass, manufactured ca. 1880-1915, and 18 fragments of selenium bleached, common after 1915, were recovered (Munsey 1970:55). Two clear glass fragments were identified as having been manufactured using hand blown pontils. Popular until about 1860 , the pontil was a metal rod that held the bottom of the bottle during manufacture. This procedure left distinguishing marks on the bottom of the vessel while the glass was still plastic (BaugherPerlin 1982:266-267). The remaining 109 pieces of clear glass, along with 64 brown/amber beer bottle glass fragments, were all identified as modern.

Another form of glass typical for this region is commonly referred to as "black" glass. Common until about 1860 , this "black" glass is actually dark green in color and can be identified when held up to a light. Typically used for wine bottles, this color was produced by introducing iron slag to the glass during manufacture.

The two complete bottles were recovered from Unit $40,0-10 \mathrm{~cm}$ bs. Both are of modern manufacture with metal screw-top lids and have been identified as originating with the Owens-Illinois Glass Company (1929-1966) of Toledo, Ohio (Toulouse 1971:403). One bottle is four inches high and the other is 5 inches. The four inch bottle has the name "Fitch" across the bottom. This may be a reference to "Fitch's Dandruff Cure" from the Ideal Dandruff Cure Company (Sellari and Sellari 1975:61).
Stratigraphically, the pre-1860 black/dark green and clear glass fragments were located from $10-60 \mathrm{~cm}$ bs. Modern glass fragments were found from the surface to depths of $70 \mathrm{~cm}$ bs. In several test units like TU 30 modern and "black/dark green" glass were present in the same level. This pattern of vertical distribution could indicate disturbed stratigraphic relationships and mixing of remains due to modern activities. This is most likely the case in the units along the fence line where the majority of glass was recovered (Figure 16). However, with small artifacts like pieces of glass, the actions of naturally occurring bioturbation can not be overlooked.

\section{Metal}

Fragments of six cut or square iron nails and one wire nail were discovered. The cut nails came from TUs $50,43,29,10$, and 5 at depths between 10 and $50 \mathrm{~cm}$ bs. The one wire nail was recovered in TU 52 between $20-30 \mathrm{~cm}$ bs. Twenty iron fencing staples were also recovered from seven units in the southern half of the site. Their vertical distribution ranged from the surface to $80 \mathrm{~cm}$ bs.

One knife fragment with a broken blade was recovered. It is 7.5 inches long from the butt end of the flat metal tang that formed the center of the handle, to the break in the blade (Figure 17). The grips which were made of a perishable material are no longer present. This is probably the type of knife called a "Green River" butcher knife (Peterson 1958:Figure 93). If so, it would date to after 1835 when Russell began to manufacture butcher and carving knives on the Green River at Greenfield, Massachusetts (Peterson 1958:64). Green River knives quickly became popular with frontiersmen throughout the West.

The knife was recovered from the "living surface" of the jacal-Feature 3. 


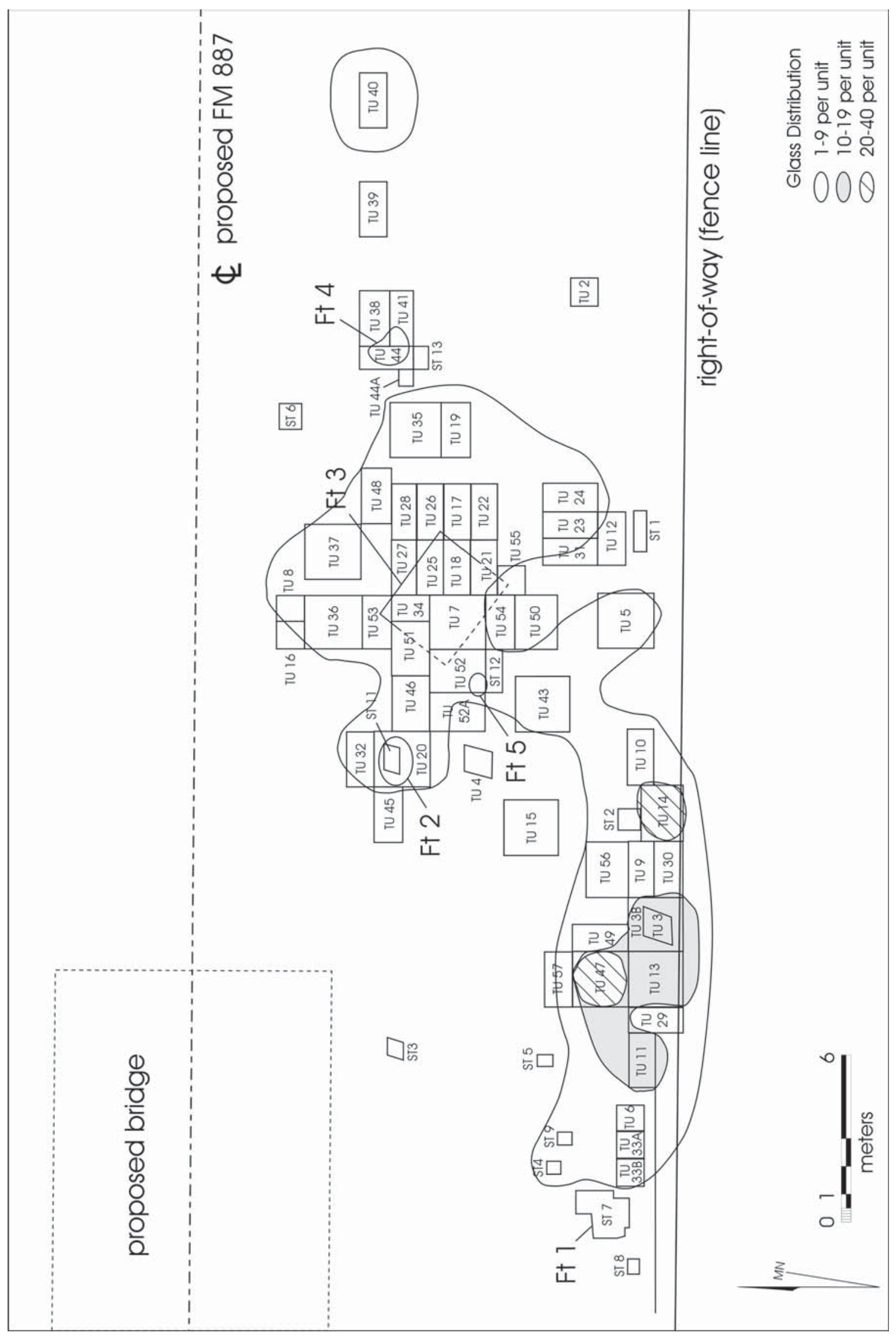

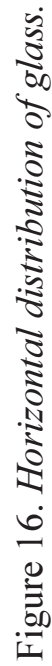




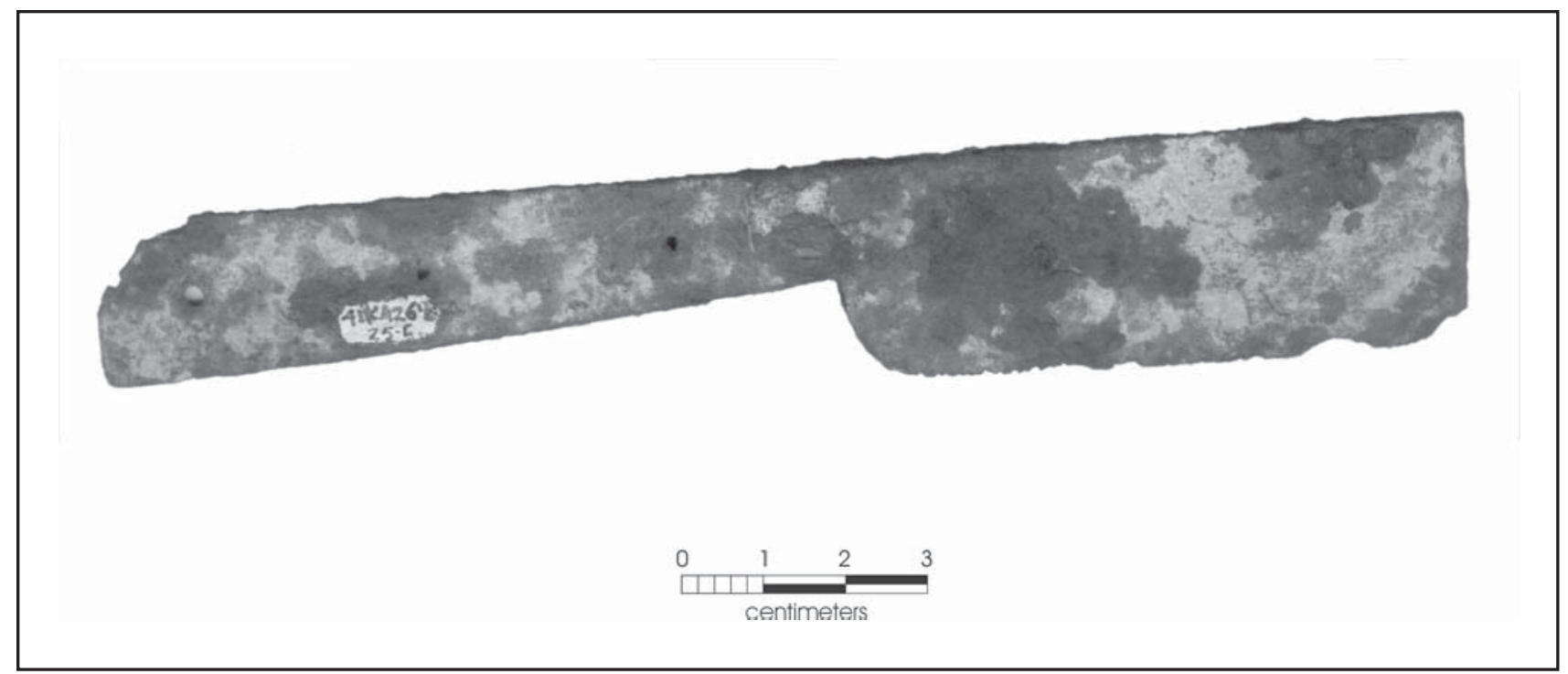

Figure 17. Fragment of possible "Green River" knife from Feature 3.

Another knife fragment appears to be part of a pocket knife. The section that extended into the bolster, or handle, is present and the blade was snapped off at its base. This artifact was found in the area along the fence in the southwest corner of the site, in Unit 13 Level C.

Fourteen tin-can fragments were also recovered. They were all very small and were found at all levels throughout the site.

An S-shaped chain link object diagnostic of Spanish horse equipment (Simmons and Turley 1980:101) was recovered from Level D in Unit 17. Spanish style bridles continued in use well into the mid-nineteenth century in the southwest United States, but in Texas they are usually limited to the Spanish occupation period.

Other metal items found on the site includes five iron fragments, two iron rod fragments, one bucket rim fragment, one iron rivet, one wire fragment, and a fragment of brass.

\section{Ammunition}

Four lead balls from early pistol or rifle use were discovered. Three of the four appear to have not been fired and can be identified following Nesmith (1992:57-60) as:
1) Item measures $12.5 \mathrm{~mm}$, weighs $11.38 \mathrm{~g}$, and could have been fired from a flintlock pistol carried by an officer, or possibly from a Kentucky rifle used in the early nineteenth century. This ball was recovered from the surface;

2) Item measures $14.5 \mathrm{~mm}$, weighs $14.81 \mathrm{~g}$, and could have been used in Officers' flintlock pistols or rifles in the early nineteenth century, or in Calvary musketoons and some Baker rifles. It was found in TU $52 \mathrm{~A}, 40-50 \mathrm{~cm}$ bs;

3) Item from $\mathrm{TU} 13$, Level $\mathrm{D}$, measures $16.5 \mathrm{~mm}$, weighs $19 \mathrm{~g}$, and could have been used in many pistols, rifles, or carbines of the early nineteenth century; and

4) This item is flat on one side and weighs $14.88 \mathrm{~g}$. The weight suggests that the original size of this ball was ca. $14 \mathrm{~mm}$.

Eleven examples of more-recent ammunition were also identified. Two .22 caliber lead bullets and a .22 short cartridge, all previously fired, were identified. Four small lead balls from modern buckshot measuring 7.62 $\mathrm{mm}$ and weighing $2.56 \mathrm{~g}$ each were recovered from TU $22 \mathrm{C}$. These are of the Eastern size 1 or Western size 5 or 6 (Logan 1959:171). 
The bases from three modern shotgun shells and one complete shell were recovered from Levels C and D along the fence line. Each shell was imprinted with different shell types. The first base reads "WINCHESTER NEW RIVAL No 12." The second shell base reads "WINCHESTER NUBLACK No 12." The third base reads "PETERS TARGET No 16." The complete shell reads "Wards - Field Load."

A number of small lead fragments were also recovered, mostly from Levels C and D. Some may be fragments of bullets, one is a piece of lead sprue from the molding of bullets. In addition, a cylindrical piece of lead nine inches long and ca. 1/3-inch in diameter may represent the bar lead customarily taken into the wilderness for use in making bullets (Russell 1957:223).

\section{Ornamental}

Three Republic of Texas Dragoons buttons were recovered (Figure 18). The buttons are $19 \mathrm{~mm}$ across and were manufactured by Scovills/Waterbury in 1837 . They have a large star with the initial " $\mathrm{D}$ " in the center and TEXAS above (Figure 18). These military issue buttons are of the two piece type invented in England about 1813 (Albert 1969:251). The button illustrated in Figure 18a was the only artifact recovered from Level C (20-30) cm bs) in TU 17 near Feature 3 (Figure 8). Level $\mathrm{C}$ is above the eighteenth-century cultural zone in this unit and was heavily disturbed by tree roots, animal burrows, and road gravel. The other two buttons (Figures $18 \mathrm{~b}$ and c) were recovered from TU 14, Level C and TU 49, Level D, both along the fence line in the southwest corner of the site.

Four cast copper or brass buttons with drilled shanks and one shank broken off a similar button were found on the site. The shanks were formed from a protuberance of metal at the back of the button drilled after the casting operation (Albert and Kent 1949:8). Identical buttons have been recovered from mission and rancho sites (Jones and Fox 1983:42; Taylor and Fox 1985:34), as well as from early nineteenth-century sites in the San Antonio area. These buttons were found in three units in the southwest quadrant of the site at levels ranging from the surface to $60-70 \mathrm{~cm}$ bs. Two undecorated faces from compound buttons measure 7/8-inch and 1/2-inch respectively. The former is made of copper, the latter of brass.

The two four-hole iron buttons from TUs 57A and $15 \mathrm{D}$ represent a slightly later period. They were used on work clothes throughout the nineteenth century. A machine-cut shell button, 3/8-inch in diameter, bears an engraved decoration resembling a flower. Such buttons began to be machine cut ca. 1850 (Meissner 1997:121). They were generally used on women's and children's clothing. A brass clothing hook, 1/2-inch long, was recovered from Unit 3, Level C. Hook and

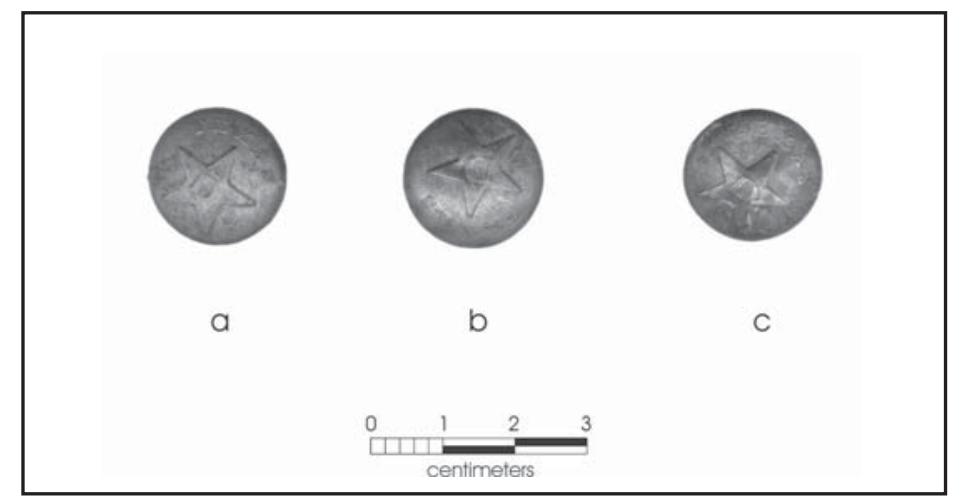

Figure 18. Republic of Texas Dragoons buttons. 
eye fasteners were made of brass until after 1900 (Cecelia Steinfeldt, personal communication 1975).

Seven glass beads were also identified. Two of the seven are blue glass and six sided. They were recovered from TUs $3 \mathrm{~B}-\mathrm{C}$ and $17 \mathrm{D}$. The remaining five: from TUs 17E, 25D, 27C, and 43E, are clear or opaque in color and are four-sided.

Using Harris's bead charts and classifications (Harris and Harris 1967), the two typologies are as follows:

\section{No. 5 B Medium, White, opaque, barrel-shaped garter bead, of compound construction. The inner layer of glass has a porcelain-like texture, while the outer layer is clear glass but has a slightly frosted appearance, probably due to age. The bead was tumbled during the manufacturing process giving it smooth edges. Harris dates this type of bead from 1700-1836.}

\section{No. 11 B Medium, Peacock Blue, opaque, barrel- shaped garter bead of simple construction. The glass has fine lines running lengthwise with the bead, giving it a texture reminiscent of striped sugarcane. The only difference between Harris' classification and the two specimens here is that the 41KA26-B beads were untumbled instead of tumbled during the manufacturing process. This results in the beads having a sharper edge. Except for this difference, the Harris description is a perfect match. According to Harris' bead chart, this type of bead was also present on sites dating from ca. $1700-1836$.}

One unidentified artifact is probably ornamental in function. It is a one-inch long hand-filed brass bar with a shank in the middle. This shank has a loop of wire going through its ring. It is possibly part of a pendant or medal associated with the three Texas Dragoon buttons. However, none of these four items were located together.

\section{Organic Material}

Mussel shell fragments appear on the catalog sheets from both the testing and mitigation phases of excavation at 41KA26-B. When this shell was reweighed during this analysis it was discovered that shell from the testing phase was no longer present in the collection and is therefore not considered in the following discussion. Over 4,321 grams (10 lbs) of shell fragments were recovered during the mitigation phase. As no notations were made in the field notes, it is assumed that no obvious clusters or lenses were present. No patterns of vertical or horizontal distribution could be identified during our analysis; the shell was homogeneous across the site. It is the author's opinion that this shell represents natural inclusion in the soils due to the proximity of Cibolo Creek. 



\section{Chapter 8: Other Historic Artifacts}

\section{Owen Ford and Anne A. Fox}

\section{Glass}

A total of 210 glass fragments and two complete bottles were collected from 41KA26-B. Identification of the samples utilized glass color and manufacturing techniques. Appendix I lists all artifacts, including glass, recovered during this project.

The clear glass section of Appendix I has been further defined here into three distinct categories: manganese bleached, selenium bleached, and hand-blown pontil. Two fragments of manganese bleached glass, manufactured ca. 1880-1915, and 18 fragments of selenium bleached, common after 1915, were recovered (Munsey 1970:55). Two clear glass fragments were identified as having been manufactured using hand blown pontils. Popular until about 1860 , the pontil was a metal rod that held the bottom of the bottle during manufacture. This procedure left distinguishing marks on the bottom of the vessel while the glass was still plastic (BaugherPerlin 1982:266-267). The remaining 109 pieces of clear glass, along with 64 brown/amber beer bottle glass fragments, were all identified as modern.

Another form of glass typical for this region is commonly referred to as "black" glass. Common until about 1860 , this "black" glass is actually dark green in color and can be identified when held up to a light. Typically used for wine bottles, this color was produced by introducing iron slag to the glass during manufacture.

The two complete bottles were recovered from Unit $40,0-10 \mathrm{~cm}$ bs. Both are of modern manufacture with metal screw-top lids and have been identified as originating with the Owens-Illinois Glass Company (1929-1966) of Toledo, Ohio (Toulouse 1971:403). One bottle is four inches high and the other is 5 inches. The four inch bottle has the name "Fitch" across the bottom. This may be a reference to "Fitch's Dandruff Cure" from the Ideal Dandruff Cure Company (Sellari and Sellari 1975:61).
Stratigraphically, the pre-1860 black/dark green and clear glass fragments were located from $10-60 \mathrm{~cm}$ bs. Modern glass fragments were found from the surface to depths of $70 \mathrm{~cm}$ bs. In several test units like TU 30 modern and "black/dark green" glass were present in the same level. This pattern of vertical distribution could indicate disturbed stratigraphic relationships and mixing of remains due to modern activities. This is most likely the case in the units along the fence line where the majority of glass was recovered (Figure 16). However, with small artifacts like pieces of glass, the actions of naturally occurring bioturbation can not be overlooked.

\section{Metal}

Fragments of six cut or square iron nails and one wire nail were discovered. The cut nails came from TUs $50,43,29,10$, and 5 at depths between 10 and $50 \mathrm{~cm}$ bs. The one wire nail was recovered in TU 52 between $20-30 \mathrm{~cm}$ bs. Twenty iron fencing staples were also recovered from seven units in the southern half of the site. Their vertical distribution ranged from the surface to $80 \mathrm{~cm}$ bs.

One knife fragment with a broken blade was recovered. It is 7.5 inches long from the butt end of the flat metal tang that formed the center of the handle, to the break in the blade (Figure 17). The grips which were made of a perishable material are no longer present. This is probably the type of knife called a "Green River" butcher knife (Peterson 1958:Figure 93). If so, it would date to after 1835 when Russell began to manufacture butcher and carving knives on the Green River at Greenfield, Massachusetts (Peterson 1958:64). Green River knives quickly became popular with frontiersmen throughout the West.

The knife was recovered from the "living surface" of the jacal-Feature 3. 


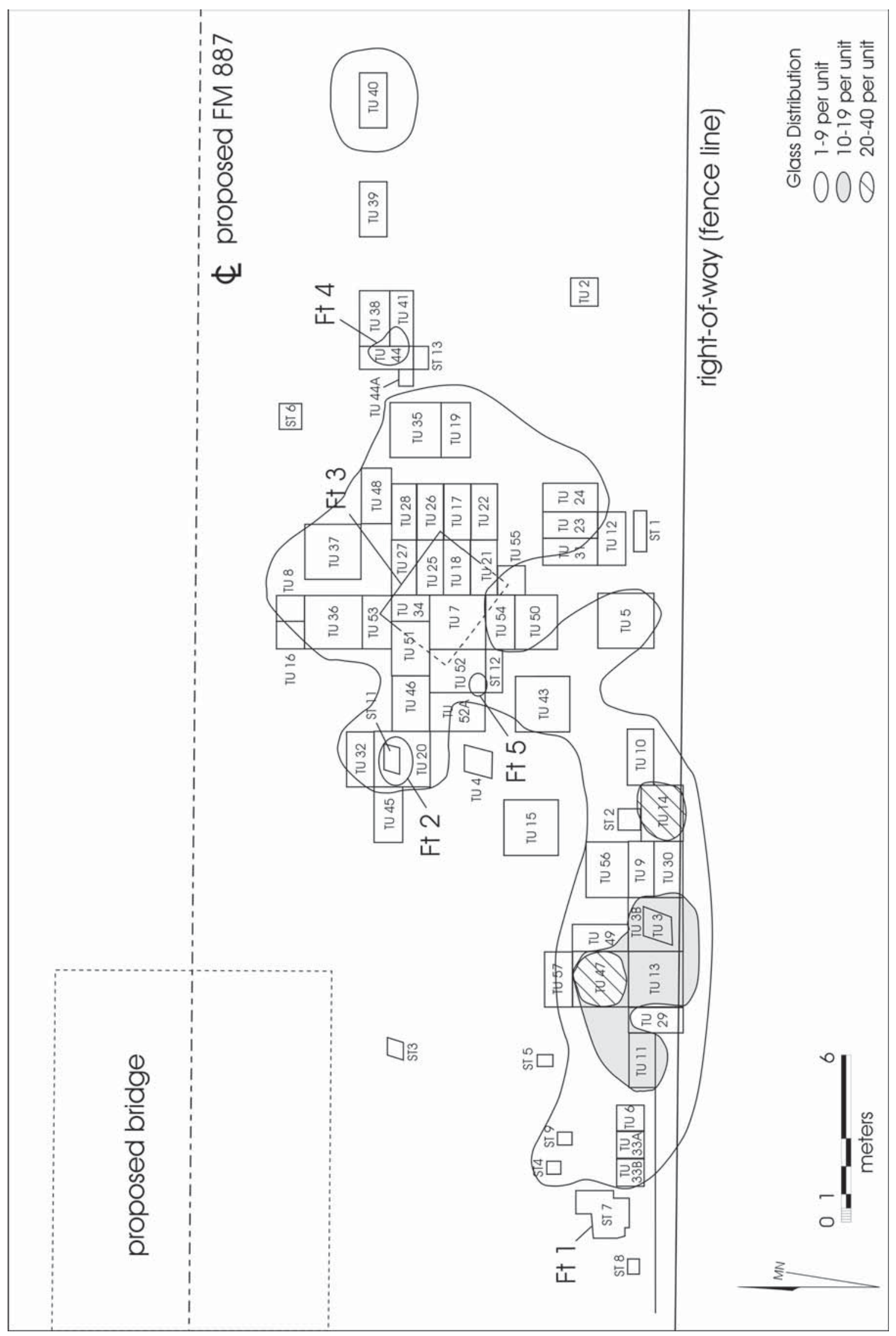

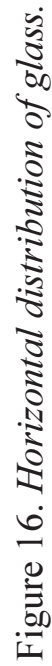




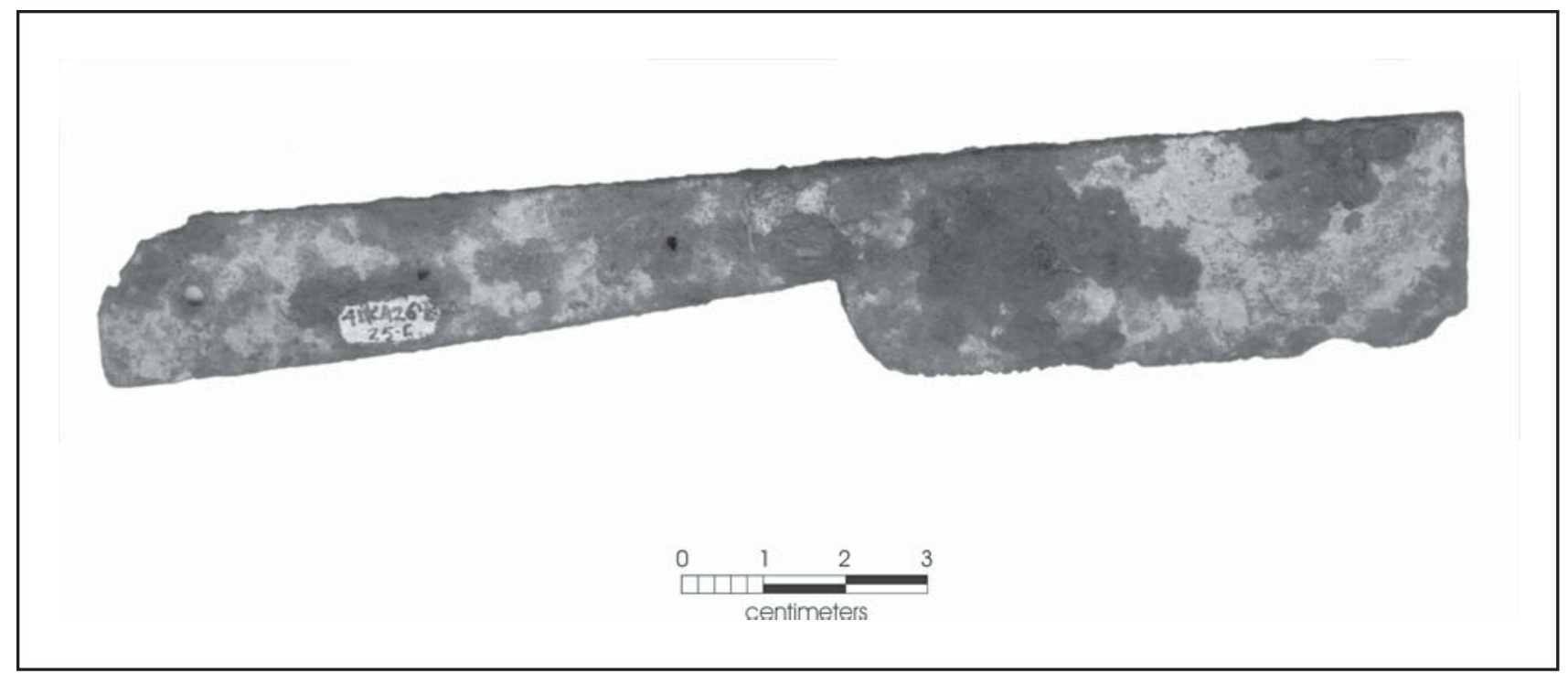

Figure 17. Fragment of possible "Green River" knife from Feature 3.

Another knife fragment appears to be part of a pocket knife. The section that extended into the bolster, or handle, is present and the blade was snapped off at its base. This artifact was found in the area along the fence in the southwest corner of the site, in Unit 13 Level C.

Fourteen tin-can fragments were also recovered. They were all very small and were found at all levels throughout the site.

An S-shaped chain link object diagnostic of Spanish horse equipment (Simmons and Turley 1980:101) was recovered from Level D in Unit 17. Spanish style bridles continued in use well into the mid-nineteenth century in the southwest United States, but in Texas they are usually limited to the Spanish occupation period.

Other metal items found on the site includes five iron fragments, two iron rod fragments, one bucket rim fragment, one iron rivet, one wire fragment, and a fragment of brass.

\section{Ammunition}

Four lead balls from early pistol or rifle use were discovered. Three of the four appear to have not been fired and can be identified following Nesmith (1992:57-60) as:
1) Item measures $12.5 \mathrm{~mm}$, weighs $11.38 \mathrm{~g}$, and could have been fired from a flintlock pistol carried by an officer, or possibly from a Kentucky rifle used in the early nineteenth century. This ball was recovered from the surface;

2) Item measures $14.5 \mathrm{~mm}$, weighs $14.81 \mathrm{~g}$, and could have been used in Officers' flintlock pistols or rifles in the early nineteenth century, or in Calvary musketoons and some Baker rifles. It was found in TU $52 \mathrm{~A}, 40-50 \mathrm{~cm}$ bs;

3) Item from $\mathrm{TU} 13$, Level $\mathrm{D}$, measures $16.5 \mathrm{~mm}$, weighs $19 \mathrm{~g}$, and could have been used in many pistols, rifles, or carbines of the early nineteenth century; and

4) This item is flat on one side and weighs $14.88 \mathrm{~g}$. The weight suggests that the original size of this ball was ca. $14 \mathrm{~mm}$.

Eleven examples of more-recent ammunition were also identified. Two .22 caliber lead bullets and a .22 short cartridge, all previously fired, were identified. Four small lead balls from modern buckshot measuring 7.62 $\mathrm{mm}$ and weighing $2.56 \mathrm{~g}$ each were recovered from TU $22 \mathrm{C}$. These are of the Eastern size 1 or Western size 5 or 6 (Logan 1959:171). 
The bases from three modern shotgun shells and one complete shell were recovered from Levels C and D along the fence line. Each shell was imprinted with different shell types. The first base reads "WINCHESTER NEW RIVAL No 12." The second shell base reads "WINCHESTER NUBLACK No 12." The third base reads "PETERS TARGET No 16." The complete shell reads "Wards - Field Load."

A number of small lead fragments were also recovered, mostly from Levels C and D. Some may be fragments of bullets, one is a piece of lead sprue from the molding of bullets. In addition, a cylindrical piece of lead nine inches long and ca. 1/3-inch in diameter may represent the bar lead customarily taken into the wilderness for use in making bullets (Russell 1957:223).

\section{Ornamental}

Three Republic of Texas Dragoons buttons were recovered (Figure 18). The buttons are $19 \mathrm{~mm}$ across and were manufactured by Scovills/Waterbury in 1837 . They have a large star with the initial " $\mathrm{D}$ " in the center and TEXAS above (Figure 18). These military issue buttons are of the two piece type invented in England about 1813 (Albert 1969:251). The button illustrated in Figure 18a was the only artifact recovered from Level C (20-30) cm bs) in TU 17 near Feature 3 (Figure 8). Level $\mathrm{C}$ is above the eighteenth-century cultural zone in this unit and was heavily disturbed by tree roots, animal burrows, and road gravel. The other two buttons (Figures $18 \mathrm{~b}$ and c) were recovered from TU 14, Level C and TU 49, Level D, both along the fence line in the southwest corner of the site.

Four cast copper or brass buttons with drilled shanks and one shank broken off a similar button were found on the site. The shanks were formed from a protuberance of metal at the back of the button drilled after the casting operation (Albert and Kent 1949:8). Identical buttons have been recovered from mission and rancho sites (Jones and Fox 1983:42; Taylor and Fox 1985:34), as well as from early nineteenth-century sites in the San Antonio area. These buttons were found in three units in the southwest quadrant of the site at levels ranging from the surface to $60-70 \mathrm{~cm}$ bs. Two undecorated faces from compound buttons measure 7/8-inch and 1/2-inch respectively. The former is made of copper, the latter of brass.

The two four-hole iron buttons from TUs 57A and $15 \mathrm{D}$ represent a slightly later period. They were used on work clothes throughout the nineteenth century. A machine-cut shell button, 3/8-inch in diameter, bears an engraved decoration resembling a flower. Such buttons began to be machine cut ca. 1850 (Meissner 1997:121). They were generally used on women's and children's clothing. A brass clothing hook, 1/2-inch long, was recovered from Unit 3, Level C. Hook and

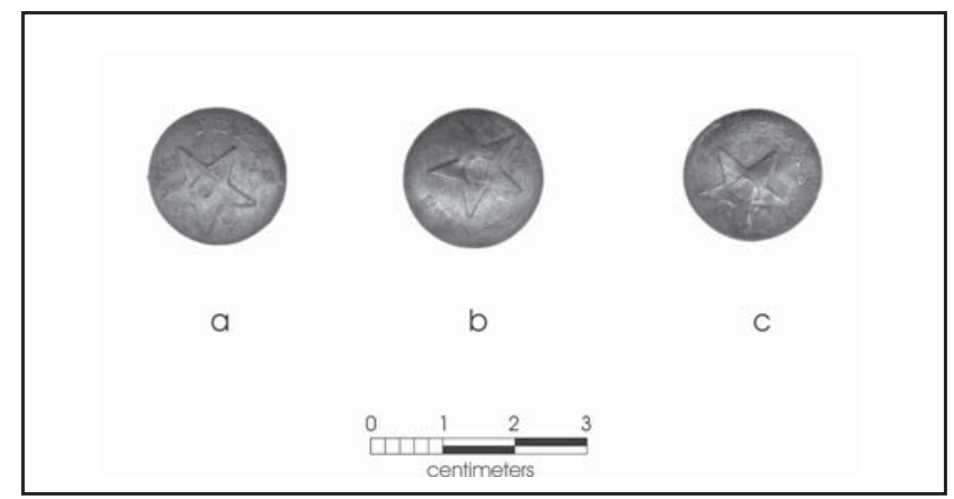

Figure 18. Republic of Texas Dragoons buttons. 
eye fasteners were made of brass until after 1900 (Cecelia Steinfeldt, personal communication 1975).

Seven glass beads were also identified. Two of the seven are blue glass and six sided. They were recovered from TUs $3 \mathrm{~B}-\mathrm{C}$ and $17 \mathrm{D}$. The remaining five: from TUs 17E, 25D, 27C, and 43E, are clear or opaque in color and are four-sided.

Using Harris's bead charts and classifications (Harris and Harris 1967), the two typologies are as follows:

\section{No. 5 B Medium, White, opaque, barrel-shaped garter bead, of compound construction. The inner layer of glass has a porcelain-like texture, while the outer layer is clear glass but has a slightly frosted appearance, probably due to age. The bead was tumbled during the manufacturing process giving it smooth edges. Harris dates this type of bead from 1700-1836.}

\section{No. 11 B Medium, Peacock Blue, opaque, barrel- shaped garter bead of simple construction. The glass has fine lines running lengthwise with the bead, giving it a texture reminiscent of striped sugarcane. The only difference between Harris' classification and the two specimens here is that the 41KA26-B beads were untumbled instead of tumbled during the manufacturing process. This results in the beads having a sharper edge. Except for this difference, the Harris description is a perfect match. According to Harris' bead chart, this type of bead was also present on sites dating from ca. $1700-1836$.}

One unidentified artifact is probably ornamental in function. It is a one-inch long hand-filed brass bar with a shank in the middle. This shank has a loop of wire going through its ring. It is possibly part of a pendant or medal associated with the three Texas Dragoon buttons. However, none of these four items were located together.

\section{Organic Material}

Mussel shell fragments appear on the catalog sheets from both the testing and mitigation phases of excavation at 41KA26-B. When this shell was reweighed during this analysis it was discovered that shell from the testing phase was no longer present in the collection and is therefore not considered in the following discussion. Over 4,321 grams (10 lbs) of shell fragments were recovered during the mitigation phase. As no notations were made in the field notes, it is assumed that no obvious clusters or lenses were present. No patterns of vertical or horizontal distribution could be identified during our analysis; the shell was homogeneous across the site. It is the author's opinion that this shell represents natural inclusion in the soils due to the proximity of Cibolo Creek. 



\section{Chapter 9: Native American Ceramics}

\section{Timothy K. Perttula}

\section{Introduction}

Texas Department of Transportation (TxDOT) excavations at the Carvajal Crossing site (41KA26B) recovered some 445 sherds-many of them less than $1 \mathrm{~cm}$ in diameter - of Native American ceramics from apparent eighteenth-century habitation contexts. The ceramic assemblage is dominated by sherds from plain bone-tempered vessels, with about 20 percent of the sherds having a sandy paste and/or an asphaltum coating. The only decorated sherd is one bonetempered sherd with overlapping brush marks on its exterior surface. There is also one small pipe sherd.

\section{Analytical Procedures}

The analysis effort focused on the 315 sherds in this assemblage that were greater than $1 \mathrm{~cm}$ in diameter. The 130 sherds less than $1 \mathrm{~cm}$ in diameter were tabulated by provenience, but received no further analytical attention (see Appendix II). Ceramic attributes examined for each sherd larger than $1 \mathrm{~cm}$ in diameter include type of decoration (if any); rim profile; lip profile; oxidation conditions (see Teltser 1993); temper, and quantity of temper in the paste ( sparse $=$ less than 5 percent; moderate $=5-25$ percent; profuse $=$ more than 25 percent, following Ricklis [1998, 1999a]); paste; interior and exterior surface treatment (including smoothing, scraping, burnishing, asphaltum coating); and sherd wall thickness.

\section{Bone-Tempered Wares}

Two principal ceramic wares are identified in the Carvajal Crossing site ceramic assemblage: (1) plain bone-tempered wares, and (2) plain sandy paste wares, occasionally with interior asphaltum coating. Of the 315 sherds larger than $1 \mathrm{~cm}$ in diameter from the Carvajal Crossing site, 257 (81.6 percent) are tempered with crushed bone. The amount of temper added to the clay paste varied from sparse $(n=98$ or 38.1 percent), to moderate ( $\mathrm{n}=94$ or 36.6 percent), to profuse ( $\mathrm{n}=65$ or 25.3 percent). As discussed below, the sparse and moderately bone-tempered sherds are more abundant from $0-30 \mathrm{~cm}$ in the deposits, while coarse bone-tempered sherds are most common from $30-60 \mathrm{~cm}$ bs. There are 20 undecorated bone-tempered rims, one decorated bone-tempered sherd, and 237 undecorated body and/or base sherds.

\section{Surface Treatment}

The one decorated bone-tempered sherd has exterior overlapping brush marks, probably made with grass stalks or a frayed stick, but otherwise the vessel appears to be undecorated. The brushed sherd is probably related to brushed and brushed-punctated cooking jars that have been found on coastal and inland Toyah phase sites, such as Berclair (41GD4; Hester and Parker 1970), Mustang Branch (41HY209-T; Ricklis 1994), Collins (41TV40; Suhm 1955), and Rowe Valley (41WM437; Elton Prewitt 1999 [personal communication]). Brushed bone-tempered ceramics have also been reported from the Biesenbach site (41WN88) on the San Antonio River (David L. Nickels, 1999 [personal communication]). That habitation site has been radiocarbon dated between ca. A.D. 1450-1670 (Nickels 1999). Mounger (1959:178) describes a small number of brushed sherds $(\mathrm{n}=25)$ from the third location of Mission Espíritu Santo (41GD1) at Goliad, established in 1749 , but these apparently are from relatively thick $(7-8 \mathrm{~mm}$ ) walled vessels with a sandy paste and occasional shell inclusions.

Only two of the bone-tempered sherds in this collection ( 0.8 percent) have an interior asphaltum coating, including one sparsely-tempered rim sherd and one profusely-tempered body sherd. About 10 percent of the rim sherds have been well burnished on interior or exterior surfaces, another 10 percent of the body sherds have evidence of being tool scraped on the vessel exterior, probably during the shaping and finishing of the vessels, and 15.8 percent have been smoothed on interior and/or 
exterior vessel surfaces; the latter are probably from cooking vessels. The well-smoothed interior surface on these vessel sherds presumably lowered the permeability of the vessels, contributing to better control of thermal shock resistance (Schiffer et al. 1994:210), and improved heating effectiveness (see Rice 1996:148). None of the sherds have preserved organic residues or other direct evidence of vessel use (i.e., Skibo 1992), probably because the overall sherd assemblage is poorly preserved, eroded, and many of the sherds are very small. Vessel wall thickness for the bone-tempered wares range from 3.6-7.7 $\mathrm{mm}$ for rims, $4.8-9.2 \mathrm{~mm}$ for body sherds, and $8.7-11 \mathrm{~mm}$ for base sherds.

\section{Rim Sherds}

All but two of the 19 bone-tempered rim sherds (89 percent) have direct (vertical or straight) rim profiles (Figure 19 and Appendix III). One inverted rim was present between $0-10 \mathrm{~cm}$ bs (Figure 19g), and one everted rim was recovered between $30-40 \mathrm{~cm}$ bs (Figure 19k). The direct rims had a variety of lip profiles: thinned ( $\mathrm{n}=2$, Figures 19d, $\mathrm{q}$ and Figure 20c), folded exterior and rounded $(n=3$, Figures $19 \mathrm{e}, \mathrm{t}$ and Figure 20b), rounded ( $\mathrm{n}=6$, Figures $19 \mathrm{~b}, \mathrm{~h}-\mathrm{j}, \mathrm{p}, \mathrm{s})$, flattened $(n=1$, Figure 19r), folded exterior and flattened $(n=1$, Figure 191), interior beveled $(n=1$, Figure 19f), folded interior and rounded ( $\mathrm{n}=2$, Figures $19 \mathrm{a}, \mathrm{m}$ and Figure 20a), and expanding-rounded $(\mathrm{n}=1$, Figure 19n). Only one of the bone-tempered rim sherds (TU 52E, $40-50 \mathrm{~cm} \mathrm{bs)} \mathrm{was} \mathrm{large} \mathrm{enough} \mathrm{to} \mathrm{estimate}$ the orifice diameter of the vessel. This rim is from a shallow sparsely-tempered bowl with a $13 \mathrm{~cm}$ orifice diameter. The rim had an interior asphaltum coating.

There are no loop or riveted handle sherds among the bone-tempered wares. By contrast, riveted loop handles are rather common in the ceramic assemblages at the second and third locations of Mission Espíritu Santo

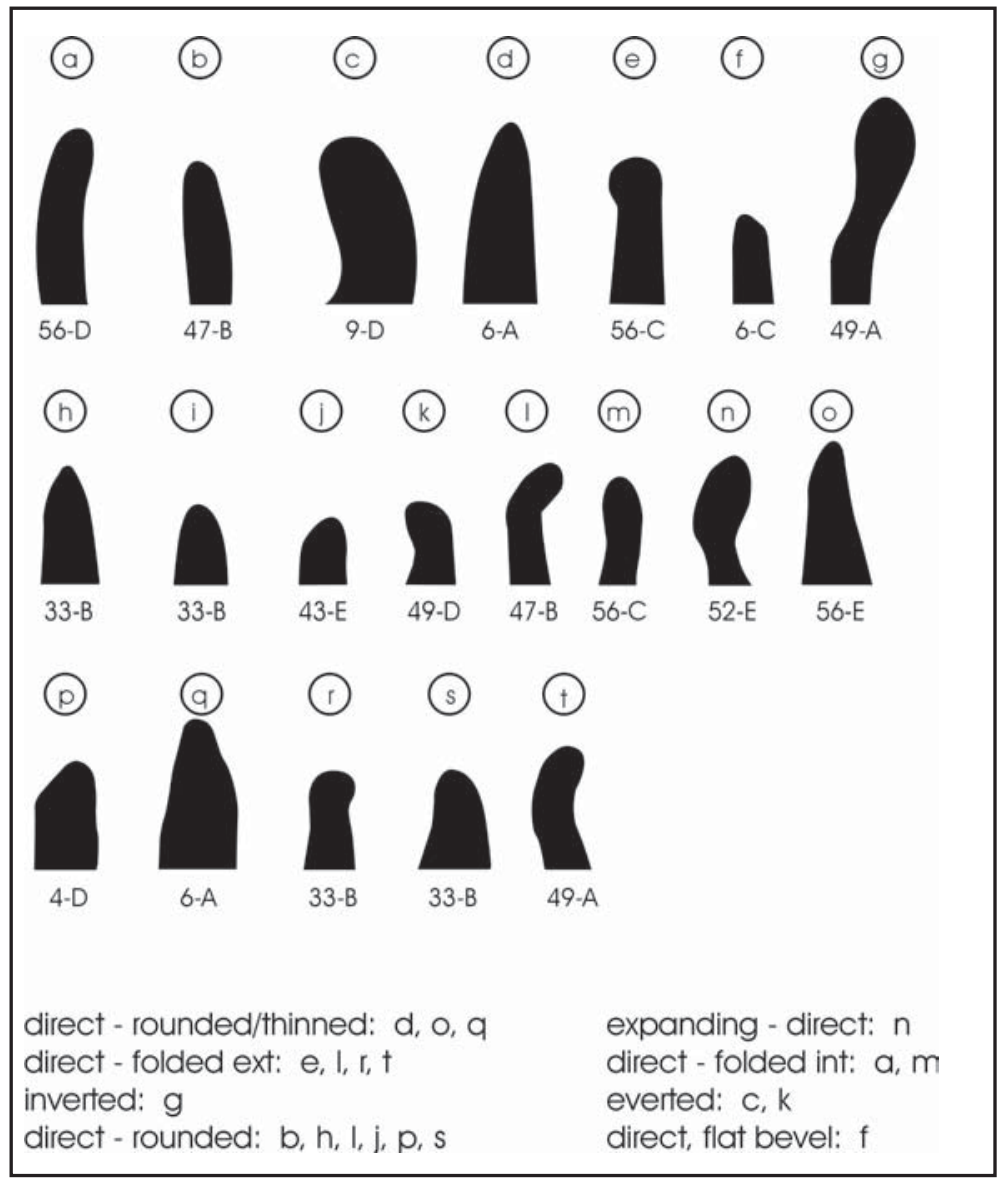

Figure 19. Rim and lip profiles from Native American sherds. 


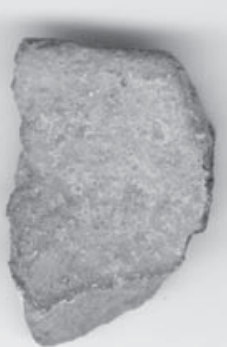

(a)

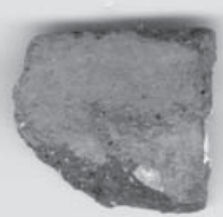

(b)

Figure 20. Selected rim sherds: (a) TU 56D, (b) TU 49A, and (c) TU 6A.

de Zúñiga (Mounger 1959; Ricklis 1998, 1999a; Walter 1997, 1999), and at Mission Refugio (Perttula, in preparation), but much less common at Mission Rosario (41GD2), which is dominated by bone-tempered sandy paste Karankawan wares with asphaltum-coated surfaces and Rockport style decorations.

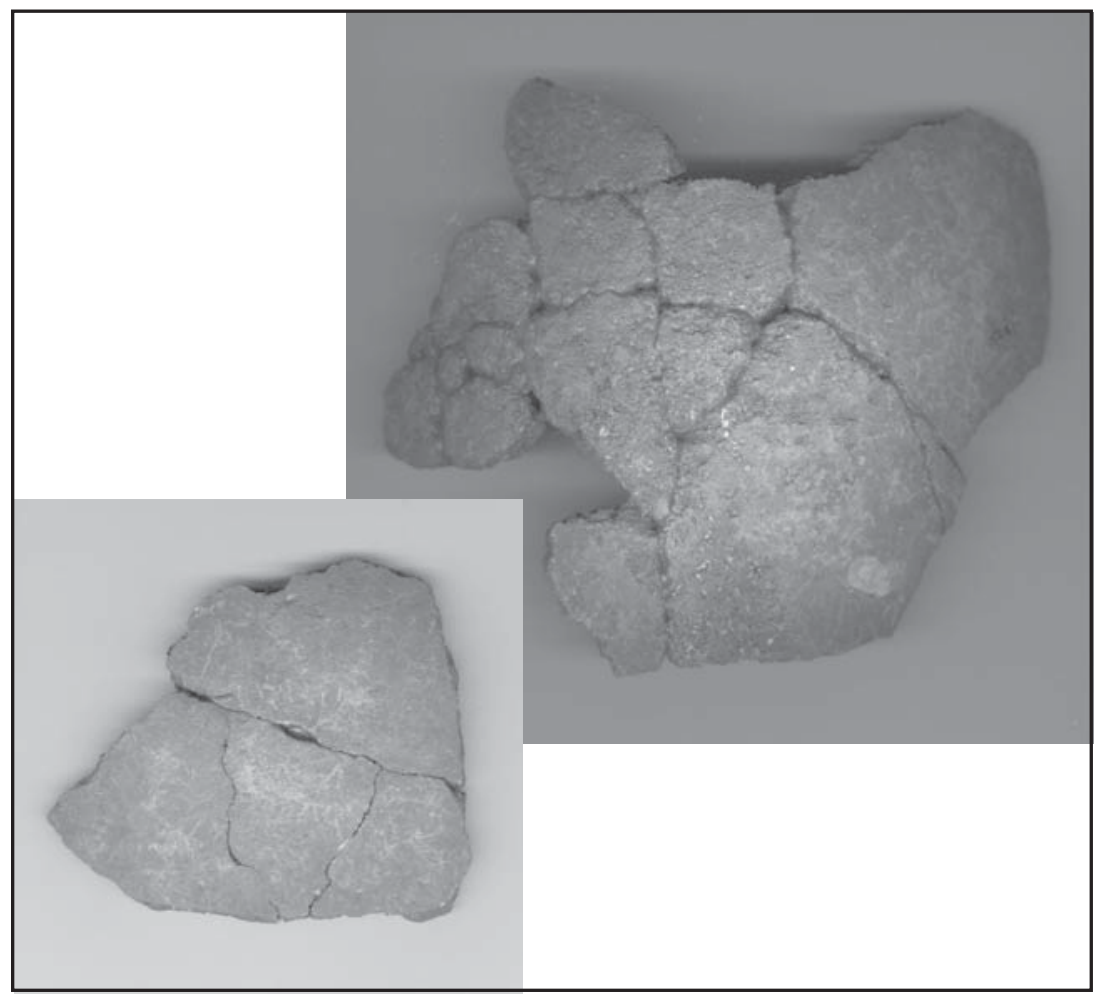

Figure 21. Vessel Section 1 from Feature 5.

\section{Vessel Section 1}

At least 27 body sherds from two plain vessels (Figure 21) were recovered from Feature 5 within TU 52 between $40-50 \mathrm{~cm}$ bs; a few unrelated sherds were also found in this context (see Appendix II). Both of these vessels, large jars or bowls profusely tempered with crushed bone, had smoothed to eroded exterior surfaces $6.4-7.5 \mathrm{~mm}$ thick vessel walls, and were fired in a reducing environment, but cooled in a high oxygen environment.

\section{Results of the INAA and Petrographic Studies}

A total of 21 sherds from the Carvajal Crossing site were submitted to the University of Missouri Research Reactor Center for instrumental neutron activation analysis (INAA), see Appendix IV for an attribute analysis of these sherds. The sherds were broken in half before submittal, with one half submitted for INAA (see Neff and Glascock, Appendix V), while the other half was submitted for petrographic analysis (Hill, Appendix VI). Nineteen or 90.5 percent of the 
special sample sherds were from bone-tempered ceramic wares, one of which had an interior asphaltum coating (Appendix IV).

According to the petrographic analysis, 13 of the special sample bone-tempered sherds have 1 percent sand grains in the clay paste and between 15-20 percent bone temper in the paste (Hill's paste group 2 and 2A). Another four (in Hill's paste group 1) have 25 percent sand grains in the paste and 1-3 percent bone temper. None contain any naturally occurring weathered rock grains, and it is reasonable to conclude that these sherds (which comprise 89 percent of the special sample) are from locally-made ceramics.

One of the bone-tempered sherds (\#206, included in Hill's paste group 0 ) has a distinctive mix of highly weathered rock grains that are naturally occurring in the paste, which is otherwise relatively sandy. These grains include potassium feldspar and plagioclase; other rock grains present include biotite and pyroxene (see Appendix VI). While visual inspection of the sherd indicated sparse bone temper, Hill's analyses indicates that \#206 had no bone temper. The combination of a relatively sandy paste, low bone temper, and a variety of weathered rock grains suggests that this sherd, along with the two sandy paste sherds (see below), are from a different clay source(s) than the remainder of the bone-tempered wares from the Carvajal Crossing site. They may represent trade wares or vessels made elsewhere that were brought to the site by Native Americans.

INAA analysis by Neff and Glascock (Appendix V) indicates that the bone-tempered wares from the Carvajal Crossing site were made locally and probably represent a "distinct local ceramic tradition." The chemical composition of the \#206 sherd, however, suggests that it is from a vessel imported into or brought to the site. In chemical composition, this sherd most closely resembles the hand-made and wheelmade coarse earthenwares recovered at the late eighteenth- early nineteenth century Tejano site at 41ZP79 in the Falcon Reservoir area (Perttula et al. 1999). Neff and Glascock's (2000) INAA analyses of these wares suggest they were locally made and not produced in Mexico.

\section{Sandy Paste Wares}

There are 58 sandy-paste sherds in this collection from Carvajal Crossing that are larger than $1 \mathrm{~cm}$ in diameter, including two rim sherds, 55 body and/or base sherds, and one pipe sherd (Appendices II and III). This represents 18.4 percent of this small sherd assemblage. The sandy paste sherds appear to be more abundant in the deeper archaeological deposits (see discussion below of the lower ceramic component). Almost 21 percent of the sandy paste sherds have an interior asphaltum coating, but none of the sandy paste sherds have an asphaltum decoration (i.e., lip bands or vertical squiggles, see Ricklis 1996:Figure 7) that would suggest an affiliation with the Rockport Black on Gray wares in the coastal Rockport phase.

The sandy paste sherds range from $5.9-8.4 \mathrm{~mm}$ in rim and body wall thickness and the single measured base sherd is $10.5 \mathrm{~mm}$ in thickness. At least in thickness, these sandy paste sherds appear to be roughly comparable to the thicker, non-Rockport sandy paste sherds reported by Hindes et al. (1999) from the 17261749 Mission Espíritu Santo site (41VT10, Tonkawa Bank site), and from the 1749-1830 Mission Espíritu Santo at Goliad (see Mounger 1959), although none from the Carvajal Crossing site had shell inclusions or any evidence of a lead glaze.

The two rim sherds, both from TU 9, 30-40 cm, have rounded lips but direct or everted rim profiles (Appendix III and Figure 19c, p). Neither has an interior asphaltum coating nor any surface treatment.

A single pipe bowl sherd with a sandy paste was recovered from TU 7, 50-60 cm bs. The bowl was only $1.3 \mathrm{~mm}$ in thickness, and the pipe itself had been fired in a reducing environment, but cooled in a high oxygen environment. Ricklis (1996:29) notes that ceramic smoking pipes "may have been quite common" in Rockport phase sites, and thus this pipe sherd may be of Rockport or Karankawan affiliation because of its sandy paste. The few ceramic pipes from Goliad (see Mounger 1959:173-174 and Plate 34), by contrast, had bone tempering. 


\section{Results of the INAA and Petrographic Studies}

Two or 9.5 percent of the special sample sherds selected for chemical and petrographic analyses had a sandy paste with no apparent temper (Appendix VI). One of the sherds had an interior asphaltum coating. The INAA results reported by Neff and Glascock (Appendix V) indicate that both sandy-paste sherds (\#201 and \#213) do not derive from the same source raw materials as the bone-tempered wares from 41KA26-B. They suggest that \#201 may represent either an import or a sherd from a vessel locally made, but from a different raw material source. This particular sherd has an interior asphaltum coating, which, in turn, suggests it may be a sherd from a vessel imported from the Karankawan groups living along the central Texas coast.

The other sherd (\#213), along with \#206 discussed above, clearly appears to be an import, as the sediments are derived from a granitic source (Hill, Appendix VI). However, INAA analyses of coarse earthenware sherds from 41ZP79 along the lower Rio Grande indicate they are similar in chemical composition to the \#213 sherd from Carvajal Crossing, and the lower Rio Grande sherds are not made in Mexico (Neff and Glascock 2000:6). Both are distinct from the South Texas chemical reference group defined from the bonetempered wares at 41KA26-B (Neff and Glascock, Appendix V).

Hill's petrographic analysis grouped both sandy paste sherds in his Paste Group 0, and he characterized them as having 3 percent to 35 percent sand grains in the paste and no bone temper grains. Both sherds (\#201 and \#213) also have a distinctive mix of highly weathered and naturally occurring rock grains in the paste, including potassium feldspar and plagioclase (Hill, Appendix VI). These three sherds are from a different clay source(s) than the remainder of the bonetempered wares from the Carvajal Crossing site, and may represent trade wares or vessels made elsewhere that were brought to the site by Native Americans.

\section{Horizontal and Vertical Distribution}

Native American ceramics at site 41KA26-B are distributed over about a $330 \mathrm{~m}^{2}$ area (Figure 22). However, the principal concentrations of ceramics are in an 8-x-5-m area between TU 10 and TU 11 near the fence line in the southwest quadrant of the site, and in Feature 5, a ceramic concentration in TU 52. Sherd densities in these two areas are more than $20-40+$ sherds per excavation unit. Outside Feature 5, few sherds are present in units associated with other features.

The 21 rim sherds from across the site represent at least 19 separate broken and discarded vessels, as discerned from differences between them in temper, oxidation conditions, body wall thickness, and surface treatment (see Appendix III). The one possible ceramic pipe sherd is from $50-60 \mathrm{~cm}$ bs in TU 7, within the boundaries of Feature 3.

Based on counts of the analyzed and un-analyzed ceramic native ware (Appendix II), the vertical distribution of ceramic sherds is:

\begin{tabular}{|c|c|c|}
\hline $0-10 \mathrm{~cm}$ & (A) & \\
\hline $10-20 \mathrm{~cm}$ & (B). & \\
\hline $20-30 \mathrm{~cm}$ & (C). & \\
\hline $30-40 \mathrm{~cm}$ & (D) $\ldots$ & \\
\hline $40-50 \mathrm{~cm}$ & (E) & \\
\hline $50-60 \mathrm{~cm}$ & (F) ...... & \\
\hline $60-70 \mathrm{~cm}$ & (G) & \\
\hline $70-80 \mathrm{~cm}$ & (H) & \\
\hline $80-90 \mathrm{~cm}$ & ( I) & \\
\hline م 100 & I & \\
\hline
\end{tabular}

Ninety percent of the sherds below $60 \mathrm{~cm}$-a total of 10 sherds - are from only two units: TU 15 and TU 43, which are immediately south and southwest of Feature 5. The considerable depths to which sherds were found in these two units suggests that two other unrecognized pit features were likely present in those areas. 


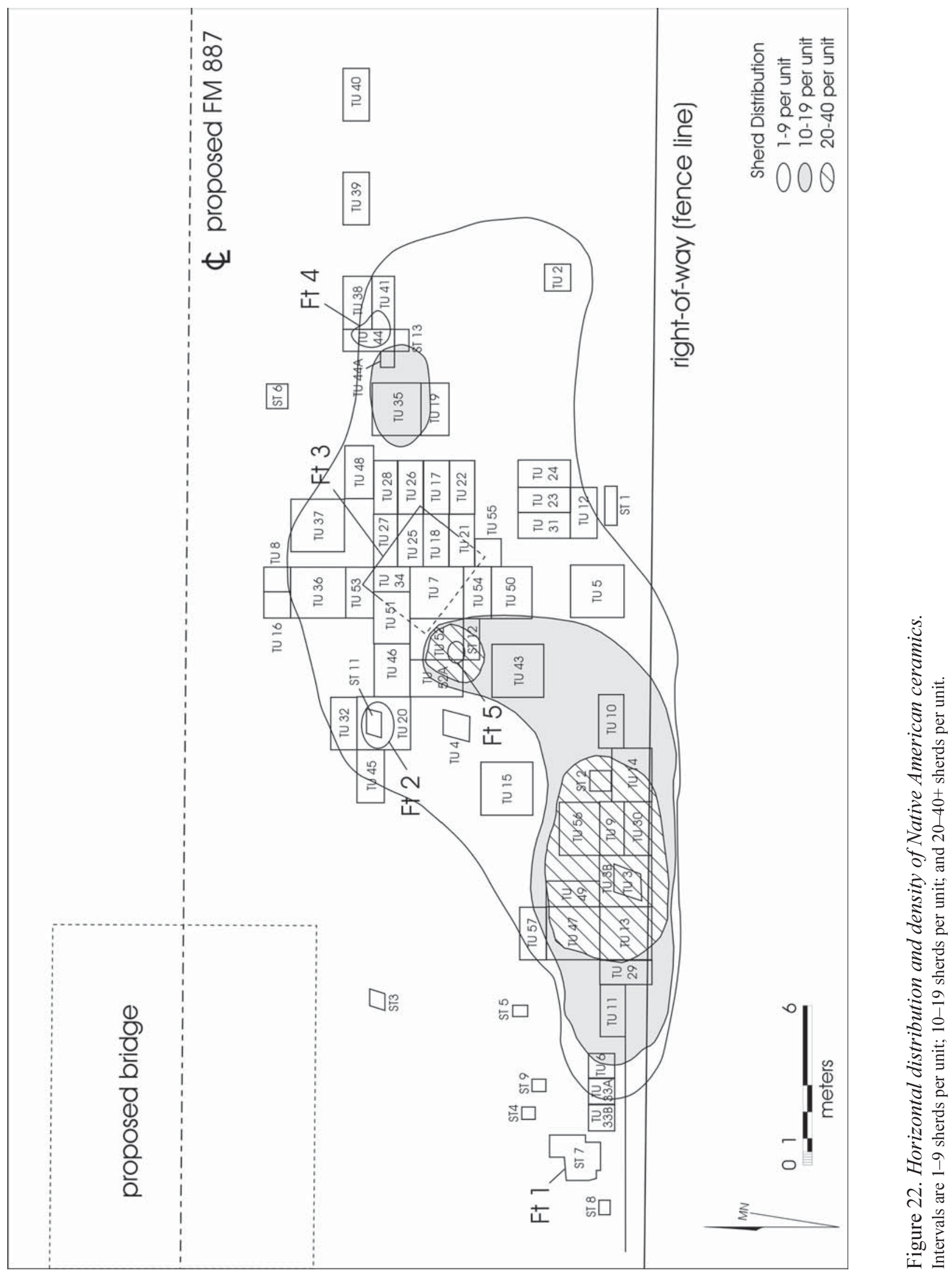


In general, the ceramic sherds from 41KA26-B are concentrated between $20-50 \mathrm{~cm}$ bs, but the vertical distribution of sherds is affected to an indeterminate degree by the fact that the majority of the upper 20 $\mathrm{cm}$ of the archaeological deposit was discarded during excavations by TxDOT archaeologists without screening the unit matrix. The large amount of sherds present from 10-20 cm bs in the absence of screening suggests that this level certainly contained ceramic sherd densities comparable to the $20-50 \mathrm{~cm}$ bs deposits. While bearing in mind that the distribution of sherds from $0-20 \mathrm{~cm}$ bs is biased by differences in recovery methods, there are interesting vertical differences in the kinds of ceramic wares identified in the assemblage. Table 13 provides the percentages of the different paste and temper classes by level (based on data provided in Appendix II).

First, the highest proportion of profusely bone-tempered sherds occurs between $40-50 \mathrm{~cm}$ bs (accounting for 37.4 percent of all sherds in that level), and 47.5 percent of all the profusely bone-tempered sherds occur in this level (Table 14). The sandy paste sherds with interior asphaltum coating are also most abundant in the 40-50 $\mathrm{cm}$ level. The highest frequencies of sandy paste sherds are from $30-40 \mathrm{~cm}$ bs and $50-60 \mathrm{~cm}$ bs (see Tables 13 and 14). By contrast, sparsely bone-tempered sherds are proportionally more common in the upper $30 \mathrm{~cm}$ of the archaeological deposit, (particularly from 0-10 cm bs, where they account for 57 percent of the sample from that level (Table 13). Moderately bone-tempered sherds are relatively common both above and below $30 \mathrm{~cm}$ bs.

Given these broad differences, two ceramic components may tentatively be identified at the site: $0-30 \mathrm{~cm}$ bs and $30-60 \mathrm{~cm}+$ bs. The components are tentative for the following reasons:

(a) While the vertical distributional data of the sherds suggests there may be two ceramic components at the site, it is important to remember that the $0-20 \mathrm{~cm}$ levels were not systematically screened and likely many sherds were overlooked during the investigations; and

(b) Sample sizes are rather small for each level from 0-60 cm bs, ranging from 14-83 sherds per level. Levels 1 and 6 had less than 16 sherds, and levels below $60 \mathrm{~cm}$ had less than three sherds each (Table 13).

The definition of ceramic components should also take into account the depositional context of the archaeological deposits, as it is important to determine if the deposits are vertically stratified, or if they occur on a depositionally stable landform where discrete vertical contexts are likely to be absent.

Table 13. Frequency of Temper and Paste Class by Depth (analyzed sherds only)

\begin{tabular}{|l|l|l|l|l|l|l|}
\hline Level & Profuse Bone & $\begin{array}{l}\text { Moderate } \\
\text { Bone }\end{array}$ & Sparse Bone & Sandy Paste & $\begin{array}{l}\text { Sandy Paste } \\
\text { w/Asphaltum }\end{array}$ & $\mathrm{n}$ \\
\hline $0-10 \mathrm{~cm}$ & $21.4 *$ & 14.3 & 57.1 & 7.1 & 0.0 & 14 \\
\hline $10-20 \mathrm{~cm}$ & 14.5 & 34.5 & 30.9 & 16.4 & 3.6 & 55 \\
\hline $20-30 \mathrm{~cm}$ & 15.9 & 34.9 & 38.1 & 11.1 & 0.0 & 63 \\
\hline $30-40 \mathrm{~cm}$ & 10.3 & 32.1 & 32.1 & 23.1 & 2.6 & 78 \\
\hline $40-50 \mathrm{~cm}$ & 37.4 & 26.5 & 19.3 & 9.6 & 7.2 & 83 \\
\hline $50-60 \mathrm{~cm}$ & 25.0 & 25.0 & 25.0 & 18.8 & 6.3 & 16 \\
\hline $60-70 \mathrm{~cm}$ & 100.0 & 0.0 & 0.0 & 0.0 & 0.0 & 1 \\
\hline $70-80 \mathrm{~cm}$ & 0.0 & 0.0 & 66.7 & 0.0 & 33.3 & 3 \\
\hline $80-90 \mathrm{~cm}$ & 0.0 & 0.0 & 0.0 & 0.0 & 0.0 & 0 \\
\hline $90-100 \mathrm{~cm}$ & 0.0 & 0.0 & 100.0 & 0.0 & 0.0 & 1 \\
\hline
\end{tabular}

*percentage of sherd type in each level 
Table 14. Vertical Distribution of Temper and Paste Classes

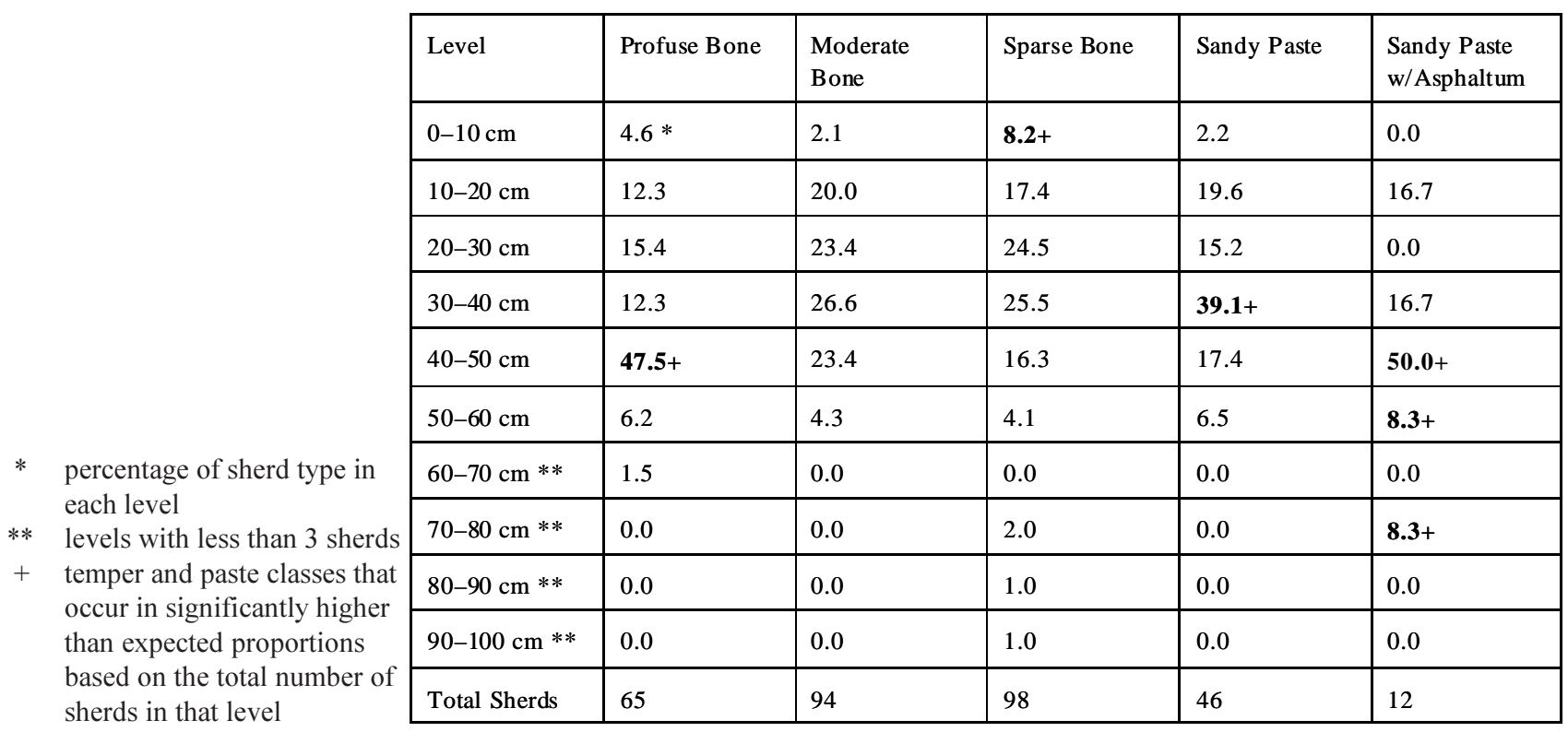

\section{Definition of Ceramic Components}

The uppermost ceramic component is characterized by higher proportions of sparse and moderately bonetempered plain wares (65-73 percent of the sherds between 0-30 cm), low amounts of coarse or profusely bone-tempered wares (between 14-20 percent), and between 7-20 percent sandy paste wares. Sherds with an asphaltum coating amount to 2.3 percent of the 132 sherds in the component. Looking at it a different way, about half of all the sparse- and moderately-tempered bone-tempered sherds from the site are present in the upper component (Table 15). Conversely, only 32 percent of the profusely-tempered bone tempered sherds are in the upper component, along with only 37 percent of the site's sandy paste ceramics and 16.7 percent of the sandy paste sherds with asphaltum. The lower ceramic component $(30-60+\mathrm{cm})$ generally has a much higher proportion of coarse or profusely bone-tempered wares, ranging from 10-38 percent by level of the 177 sherds in these lower levels. The highest frequencies of coarse bone-tempered sherds is between $40-60 \mathrm{~cm}$. While still abundant, sparse and moderate bone-tempered sherds are less abundant below $30 \mathrm{~cm}$ bs (46-64 percent), particularly below $40 \mathrm{~cm}$ bs. More than 66 percent of all the coarse bonetempered sherds occur in the lower component (Table 15). Sandy paste sherds are slightly more common in

Table 15. Summary of Differences Between Ceramic Components

\begin{tabular}{|l|c|c|c|c|c|c|}
\hline Depth & Sparse bone & $\begin{array}{c}\text { Moderate } \\
\text { Bone }\end{array}$ & Profuse Bone & Sandy Paste & $\begin{array}{c}\text { Sandy Paste } \\
\text { w/Asphaltum }\end{array}$ & Total \\
\hline $0-30 \mathrm{~cm}$ & $50.0 *$ & 45.7 & 32.3 & 37.0 & 16.7 & 132 \\
\hline $30-60 \mathrm{~cm}$ & 45.9 & 54.3 & 66.1 & 63.0 & 75.0 & 177 \\
\hline below $60 \mathrm{~cm}$ & 4.1 & 0.0 & 1.5 & 0.0 & 8.3 & 6 \\
\hline
\end{tabular}

* proportions of temper and paste class 
the lower ceramic component, comprising 16.8-25.7 percent of the assemblage by level, while 5.1 percent of the sherds have an asphaltum coating. Thus, asphaltumcoated sherds are 2.2 times more common in the lower ceramic component than they are in the upper ceramic component. However, 63-75 percent of the sandy-paste sherds and sandy-paste sherds with asphaltum coating are in the lower component (Table 15).

Vessel rim and lip profiles appear to be different between the two components, although only 21 rim sherds are present in the assemblage. The only rim and lip profiles that are shared between the upper and lower components are direct-rounded, direct-thinned, and direct-folded interior and rounded classes (see Appendix III and Figure 19). Rim-lip profiles present only in the lower component include two everted rims and a single unique rim from TU 52E (Feature 5) with a direct but expanding (i.e., direct-thickened) profile and a rounded lip. Restricted to the upper component are the following rim-lip profile classes: direct-folded exterior-rounded; inverted-rounded; direct-flattened; direct-folded exterior-flattened; and direct-interior beveled-flattened. The relative abundance of flattened lips in the upper component at 41KA26-B may have temporal as well as functional significance given the greater frequency of flattened lips in post-1790 (Zone 1) bone-tempered ceramics at Mission Rosario (Ricklis 1998:89) compared to earlier ceramics at Mission Espíritu Santo at Goliad (Ricklis 1998:Table 7), and greater amounts of deep bowls at Rosario.

There are also differences between the two ceramic components in the conditions under which the ceramic vessels were fired. Based on a sample of 41 sherds from the two components where oxidation conditions were determined (following Teltser 1993), the sandy paste sherds (all from the lower component) were primarily fired in a reducing or low oxygen environment. By contrast, 15.4 percent of the bone-tempered sherds from the lower component were fired in an oxidizing or high oxygen environment. None of the upper component sherds were oxidized during firing.

Approximately 83 percent of the upper ceramic component bone-tempered sherds are from vessels that were reduced during firing, while only 69 percent of the bone-tempered sherds in the lower component were reduced during firing. Eighty percent of the sandy paste sherds (all from the lower component), however, were from vessels fired in a reducing environment. In the case of the upper component, 74 percent of the bone-tempered sherds were from reduced vessels that were then cooled in a high oxygen environment, compared to 55 percent of the lower component bone-tempered sherds. Sherds from incompletely oxidized vessels comprise between 11.1-17.4 percent of the bone-tempered and/or sandy paste sherds from the two components.

The proportions of oxidizing conditions in the sherds from both components at 41KA26-B are similar to the ceramics from the Nuestra Señora del Refugio mission (41RF1) excavations (see Perttula, in preparation) in that the sherds from both sites are from vessels mainly fired in a reducing environment, but cooled in a high oxygen environment. That the Carvajal Crossing (41KA26-B) and Refugio mission ceramics are different, however, is apparent in the much lower proportion of sherds with asphaltum at Carvajal Crossing, particularly in the upper component. The proportion of asphaltum-coated sherds in the lower component at the Carvajal Crossing site is 3-4 times lower than at the Refugio mission.

\section{Temporal, Functional, and Cultural Affiliations of the Native American Ceramics}

The Native American ceramics from 41KA26-B are thought to date to much of the eighteenth century, and may well be contemporaneous with the two different Spanish occupations of the nearby El Fuerte del Cibolo, occupied between 1734-1737 and 1771-1782 (see Thonhoff 1992). The Oxidizable Carbon Ratio (OCR) dates associated with Feature 3, buried at a depth of 30-50 cm bs (Table 5), suggest that the lower ceramic component at the site may date to the latter part of the eighteenth century (after 1781). There are also similarities in the ceramic paste and temper groupings between the Carvajal Crossing site, the midto late-eighteenth century bone-tempered plainwares at Mission Espíritu Santo at Goliad, and the post-1795 ceramics at Mission Refugio (Perttula, in preparation), that suggest that the Native American ceramic at the Carvajal Crossing site may have continued to be 
manufactured after ca. 1800. These similarities—such as the predominance of sparse to moderately bonetempered ceramics, and low amounts of sherds with asphaltum coatings and/or decorations - can also find parallels in pre-1650 inland coastal prairie Toyah phase components (see Black 1989; Hester and Parker 1970; Ricklis 1995b, 1998, 1999a), a point that will be returned to.

Considering the Native American ceramics from 41KA26-B on their own merit, there is little if any definitive temporal information available in the assemblage to confidently establish their age within the eighteenth century, or indeed establish whether the ceramics can even be shown to be Prehistoric or early Historic in age. Of course, this situation relates to the difficulty in evaluating the age of a bonetempered plainware ceramic assemblage on the central coastal Plain of Texas that has prehistoric (ca. A.D. 1300-1700) antecedents in the bone-tempered Leon Plain ceramic tradition of the Toyah phase (Hester 1989b; Ricklis 1995b; Walter 1999), and to the overwhelming predominance (90-100 percent of the sherds) of bone-tempered [Goliad Plain] ceramics from other well-studied eighteenth century missions on the central coastal Plain of Texas. However, selected comparisons with the 1795-1830 Mission Refugio ceramics may provide a tentative temporal context for the upper and lower Carvajal Crossing site ceramic component assemblages.

The analysis of the paste and decorative elements of the Native ceramics from two trash pits at Refugio, Feature 1 (Analysis Units 1 and 2; hereafter AU 1 and AU 2) and Feature 2 (AU 3), suggests that Feature 2 is slightly older than Feature 1, based on a higher proportion of asphaltum-coated ceramics in the sandy paste ceramics from Feature 2 (Perttula, in preparation). Both date after 1790 .

The AU 3 ceramics are dominated by moderately tempered bone-tempered sherds ( 55 percent), followed by sparsely tempered (19 percent) and profusely tempered bone-tempered sherds. The bone-tempered ceramics are almost exclusively plain, with the exception of one brushed sherd. Only three percent of the bone-tempered sherds have an asphaltum coating-pointing to inland coastal prairie affiliations in the ceramics-while more than 42 percent of the sandy paste sherds have an asphaltum coating. The sandy paste sherds are primarily plain wares, but two sherds may have portions of Rockport Black on Gray II designs. The slightly later AU 1/AU 2 ceramics at Refugio are also dominated by bone-tempered wares, but there is a much higher proportion of sparsely-tempered bone-tempered ceramics (34 percent) than in AU 3, and conversely lower proportions of moderately-tempered bone-tempered ceramics (38-39 percent). Like AU 3, about 3 percent of the bone-tempered wares have an asphaltum coating. Sandy paste sherds comprise 22-25 percent of the sherds in these analytical units (compared to 21 percent in AU 3 ), but only 21-24 percent have an asphaltum coating; this is about 50 percent less than in the earlier AU 3. Small amounts of bone-tempered ceramics are decorated with painted lines and bands (Goliad Red on buff), brushing, and incising, and Rockport Black on Gray I and Black on Gray II sherds are present. Decorated sherds are much more common in AU 1/AU 2 contexts than they are in AU 3.

The lower ceramic component at Carvajal Crossing can be roughly equated with AU 3 at Refugio in that it has higher proportions of profusely tempered plain bone-tempered pottery; of probable related temporal (as well as ethnic) significance is the fact that the ca. 1749-1790 bone-tempered ceramics at Goliad (41GD1) are dominated by profusely tempered bonetempered plainwares (Ricklis 1998, 1999a). This lower ceramic component at the Carvajal Crossing site also has comparable amounts of sandy paste sherds, but lower amounts of sandy paste sherds with an asphaltum coating; the proportion of asphaltum-coated and/or decorated sherds is 6.4 percent at Carvajal Crossing and 11.6 percent in AU 3 at Refugio. By comparison, only 0.4 percent of a sample of sherds at Goliad have an asphaltum coating or decoration, but at Rosario, more than 40 percent of the sherds have an asphaltum coating or decoration (Ricklis 1999a: Table 6). Both AU 3 at Refugio and the lower ceramic component have very low amounts of decorated sherds, and brushed sherds are present in both components.

The upper ceramic component at Carvajal Crossing may be about the same age as AU 1 and AU 2 at Refugio. They have comparable proportions of sparse to moderate amounts of bone temper added to the paste (68-81 percent at Carvajal Crossing and 69-72 percent 
at Refugio); sandy paste sherds represent between $12-$ 20 percent of the sherds at the former site, and 22-25 percent at Refugio; few of the bone-tempered sherds at either site have an asphaltum coating (which is also the case at the Goliad mission); and the overall proportion of asphaltum-coated or decorated sherds is low at both sites (2.6 percent at Carvajal Crossing and 7.5-8 percent at Refugio), while the proportion of sandy paste sherds with asphaltum is between 20 24 percent; and they both have examples of brushed bone-tempered sherds. The primary difference between the ceramics at the two sites is the absence of Rockport Black on Gray sherds and Goliad Red on Buff sherds at Carvajal, and their relative abundance at Refugio.

\section{Summary}

To summarize the findings of the analysis of the aboriginal ceramics from the Carvajal Crossing site (41KA26-B), the upper and lower ceramic assemblages may be contemporaneous in part with the Espíritu Santo missions at 41VT11 and Goliad (41GD1), with Mission Refugio (41RF1), and perhaps as well as with the pre-1780 settlement of Rosario (41GD2). The ceramics may all date to the late eighteenth century.

The small sherd assemblage is dominated by plain bone-tempered ceramics related to both Leon Plain and Goliad Plain (e.g., Hester 1989b:224). In most particulars, the Carvajal Crossing ceramics are most closely affiliated with, and technologically related to, prehistoric inland coastal prairie Toyah phase components in south Texas in that they are:

(1) Dominated by plain bone-tempered ceramics that have primarily sparse to moderate amounts of bone added to the paste, but sandy paste sherds are also relatively abundant;

(2) There are few, if any, decorated sherds, although the brushed sherd from Carvajal Crossing may be related to the brushed and brushed-punctated sherds noted in several Toyah phase components in central and southern Texas, and to brushed pottery at Goliad and Mission Refugio; and
(3) There are comparable proportions of asphaltumcoated and/or asphaltum-decorated sherds, but with less asphaltum-coated sherds or asphaltumdecorated sherds than at Mission Rosario or nonmission Karankawan sites, but proportionally more than at the second, third, and final locations (1725-1790) of Mission Espíritu Santo (see Hindes et al. 1999; Mounger 1959; Walter 1997, 1999).

However, the Carvajal Crossing site ceramics probably were not made in one of the central coastal Plain missions, because those assemblages have between 90-100 percent bone-tempered pottery, compared to only 82 percent at Carvajal Crossing. Considered together, then, it is clear that the bone-tempered wares referred to as Leon Plain and Goliad Plain reflect the "persistence of Late Prehistoric traditions and technologies into the Protohistoric and Historic eras" (Walter 1999:118), and that the Carvajal Crossing site is part of that technological tradition. 



\section{Chapter 10: Lithic Artifacts}

\section{Steve A. Tomka}

A total of 256 chipped lithic artifacts were recovered from 41KA26-B (Appendix I). Eleven of these could be categorized into the following functional groups: one arrow point, four scrapers, four probable gunflints, a multi-functional scraper-graver, and one knife. Function was partially determined by low-powered (80x) micro-wear analysis. Seven unifacially flaked artifacts and one bifacially flaked item could not be grouped into functional categories. They are classified as indeterminate unifacial and bifacial artifacts, respectively. Eight flake cores were recovered (Table 16), in addition to 229 pieces of unmodified lithic debitage. All artifacts are of chert, with the fine-grained variants greatly outnumbering the coarse-grained variety. The proportion of corticate artifacts within the collection suggests that the material was obtained in the site's vicinity.

Although a larger number of lithic specimens were originally collected in the field, a systematic and careful inspection of the collection resulted in the reclassification of 206 of these as either fire-cracked rock and/or heat shatter $(n=148)$, heat spalls $(n=31)$, and mechanically created angular debris $(n=27)$. The large quantity of heat damaged chert pieces suggests that the surface of the site may have been heavily impacted by fire although it is possible that this damage may have been Prehistoric or Protohistoric in age. However, the absence of heat spalled debitage suggests perhaps that the heat shattered rocks were surface artifacts. The presence of numerous large to mediumsize chert pebbles with heavily crushed surfaces and rust streaks also indicates substantial damage derived from heavy machinery. Overall, the surface of the site appears to have been heavily impacted by postdepositional factors consisting primarily of fire and heavy machinery.

\section{Arrow Point}

A single arrow point proximal fragment, classified as a Cuney type, was recovered (Table 16, Figure 23a). Cuney points appear in the later portion of the Late Prehistoric period but seem to be most common during the Fulton Aspect (A.D. 1600-1800) of the
Historic period (Suhm and Jelks 1962:271; Turner and Hester 1993:210).

The specimen has a parallel to very slightly expanding stem and a moderately concave base. It has broad slightly downward pointing shoulders and recurved blade edges. The blade has been broken in use and both the recurved blade outline and the irregular serrations on its edges indicate blade resharpening. It was recovered in Level F (50-60 cm bs) of Unit 52A. The normal distribution for Cuney points is the central part of east Texas and occasionally central and south Texas.

\section{Knife}

A single secondary flake with an irregularly scalloped straight edge is an expedient knife (Table 16). The modification present on its working edge derives from use and purposeful retouch is absent on the specimen. The flake blank is $42 \mathrm{~mm}$ long and the knife exhibits a $41 \mathrm{~mm}$ long cutting edge. The specimen was recovered in Level G of Unit 50.

\section{Scrapers}

A total of four specimens are included in this category (Table 16). Based on the location of the working edge they consist of a side scraper, two end scrapers, and one combination end/side scraper. Based on the degree of retouch on their working edges, one of the end scrapers and the side scraper are expedient tools, the combination end/side scraper and the additional end scraper have minimally retouched working edges. Two expedient tools are small hard hammer stone tertiary flakes with corticate striking platforms. The minimally retouched end scraper and combination end/side scraper are both fashioned on large secondary hard hammer stone flakes.

\section{Multi-functional End Scraper/Graver}

A single multi-functional end scraper-graver was recognized in the collection (Table 16, Figures 23b-c). The specimen has two minimally retouched graver tips on opposite corners of its distal margin. The manufacture of a third working tip may have been 


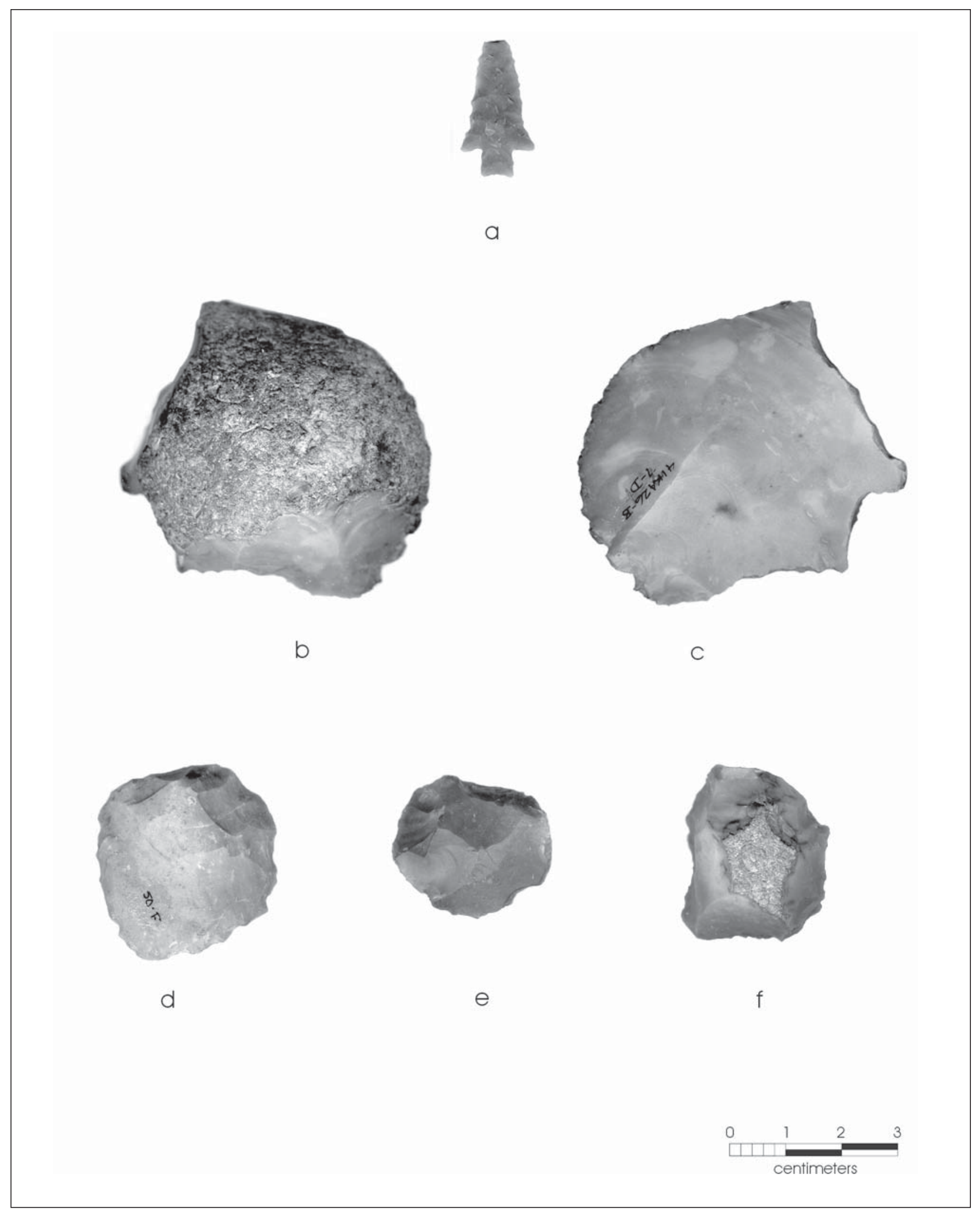

Figure 23. Chipped lithic artifacts from 41KA26-B. (a) Cuney Arrow point; (b-c), Multi-functional scrapergraver; (d-e), probable gunflints; (f), gunflint made on recycled uniface. 
Table 16. Nondebitage Lithic Artifacts, 41KA26-B

\begin{tabular}{|c|c|c|c|c|c|c|c|c|}
\hline Unit & Level & Lot Nr. & Tool Type & $\begin{array}{l}\text { Max. } \\
\text { Length } \\
(\mathbf{m m})\end{array}$ & $\begin{array}{c}\text { Max. Width } \\
(\mathrm{mm})\end{array}$ & \begin{tabular}{|c|} 
Max. \\
Thickness \\
(mm)
\end{tabular} & Blank/Completeness & Notes \\
\hline & & & Arrow Points & & & & & \\
\hline \multirow[t]{2}{*}{52} & 6 & $52 \mathrm{~A}-\mathrm{F}$ & Cuney Prox., Frag. & & 13 & 3 & Indeterminate & One ear broken \\
\hline & & & Probable Gun Flints & & & & & \\
\hline \multirow[t]{2}{*}{50} & 6 & $50-\mathrm{F}$ & Specimen \# 1 & 33 & 33 & 7 & Tertiary Flake & Thin, marginally bifacially flaked \\
\hline & & 0 & Specimen \# 2 & 28 & 24 & 7 & Tertiary Flake & Mainly unifacially flaked \\
\hline 43 & 8 & $43-\mathrm{H}$ & Specimen \# 3 & 33 & 27 & 16 & Secondary Flake & Recycled uniface \\
\hline \multirow[t]{2}{*}{13} & 3 & $13-\mathrm{C}$ & Specimen \# 4 & 23 & 23 & 11 & Secondary Flake & Recycled uniface \\
\hline & & & Scrapers & & & & & \\
\hline 47 & 2 & $47-\mathrm{B}$ & Combination end/side scraper & 43 & 57 & 21 & Secondary Flake & Minimally retouched \\
\hline 23 & 4 & 23-D & End Scraper & 55 & 70 & 11 & Secondary Flake & Minimally retouched \\
\hline 3 & 3 & $3-\mathrm{C}$ & End Scraper & 12 & 15 & 7 & Tertiary Flake & Expedient \\
\hline \multirow[t]{2}{*}{45} & 2 & 45-B & Side Scraper & 31 & 22 & 10 & Tertiary Flake & Expedient \\
\hline & & & Multi-functional Tool & & & & & \\
\hline \multirow[t]{2}{*}{7} & 4 & 7-D & Scraper-Graver & 56 & 49 & 22 & Split Cobble & Minimally Retouched \\
\hline & & & Knife & & & & & \\
\hline \multirow[t]{2}{*}{50} & 7 & $50-\mathrm{G}$ & Expedient Knife & 42 & 21 & 23 & Secondary Flake & Corticate platform w. one working edge \\
\hline & & & Indeterminate Unifaces & & & & & \\
\hline 13 & 5 & $13-\mathrm{E}$ & Indeterminate Artifact & 23 & 24 & 8.5 & Secondary flake & No use-wear evident \\
\hline 52 & 5 & $52-\mathrm{E}$ & Indeterminate Proximal Frag. & & & 5 & Tertiary Flake Frag. & One minimally retouched edge \\
\hline 30 & 3 & $30-\mathrm{C}$ & Indeterminate Edge & & & 11 & Tertiary Flake Frag. & \\
\hline 13 & 3 & $13-\mathrm{C}$ & Indeterminate Medial Frag. & & & 5 & Secondary Flake Frag. & Medial flake frag., w., two retouched edges \\
\hline 11 & 2 & $11-\mathrm{B}$ & Indeterminate Distal Frag. & & 31 & 14 & Secondary Flake Frag. & Distal flake frag., w., one retouched edge \\
\hline 47 & 2 & $47-\mathrm{B}$ & Indeterminate Edge & & & 6 & Tertiary Flake Frag. & May represent broken gun flint \\
\hline \multirow[t]{2}{*}{47} & 2 & $47-B$ & Indeterminate Edge & & & 4.5 & Tertiary Flake Frag. & Two unifacially retouched edges \\
\hline & & & Indeterminate Bifaces & & & & & \\
\hline \multirow[t]{2}{*}{17} & 4 & 17-D & Indeterminate Biface Frag. & & 27 & 11 & Indet. & Primarily unifacially flaked; may be reworked uniface \\
\hline & & & Cores & & & & & \\
\hline 15 & 4 & $15-\mathrm{D}$ & Flake Core & 63 & 46 & 38 & Complete & Group I, Tested cobble \\
\hline 47 & 4 & 47-D & Flake Core & 71 & 54 & 42 & Complete & Group II, Split cobble \\
\hline 52 & 5 & 52-E & Flake Core & 84 & 58 & 45 & Complete & Group II, Split cobble \\
\hline 36 & 5 & $36-\mathrm{E}$ & Flake Core & 54 & 46 & 28 & Complete & Group III, Unidirectional core \\
\hline 58 & & 58 & Flake Core & 91 & 56 & 49 & Complete & Group III, Unidirectional core \\
\hline ST2-E & 5 & & Flake Core & 54 & 51 & 22 & Fragment & \\
\hline 11 & 2 & $11-\mathrm{B}$ & Flake Core & 33 & 32 & 20 & Fragment & \\
\hline ST-6 & 4 & & Flake Core & 39 & 23 & 17 & Fragment & \\
\hline
\end{tabular}

attempted but not finished prior to discard. Between the two graver tips, the distal portion of the blank exhibits substantial step fracturing, rounding, and polish indicative of scraper wear. Although some of the step fracturing derives from the manufacture, the other use-wear suggests the working of a rather hard material such as bone. The blank used in making the tool appears to be a split cobble.

\section{Indeterminate Unifaces}

A single complete specimen and six flake fragments are included in this category (Table 16). These specimens represent items that could not be classified into functional tool categories due to their fragmentary nature or lack of use-wear. The single complete specimen is a hard hammer stone secondary flake with a corticate platform. It exhibits three flake removals along its side and distal ends. Although some crushing is present in these flake scars, its irregular nature and the varied size of the micro-flake scars suggest that the modification derives from post-depositional alteration rather than use.

\section{Indeterminate Biface}

A single bifacially flaked medial fragment is included in this group (Table 16). Although it has a roughly biconvex cross-section, an examination of its obverse and reverse faces indicates that the majority of the flaking is primarily unifacial. This suggests that the specimen may represent a uniface fragment that was reflaked on its ventral surface. The presence of an overshot flake scar on one end is consistent with the failure of longitudinally directed removals that are designed to thin the proximal end of unifacial tools. The nature of the break on the opposite end could not be determined. 


\section{Probable Gunflints}

A total of four probable gunflints have been recognized in the collection (Table 16, Figures 23d-f). Two are roughly rectangular marginally flaked specimens. The larger of the specimens $(33 \times 33 \times 7 \mathrm{~mm})$ is a tertiary flake with marginal retouch on both faces (Figure 23d). While retouch is present on all four sides of both faces, it only extends to a maximum of $9 \mathrm{~mm}$ from the edge on the ventral face. The flake has a convex transverse cross-section and the marginal retouch on the dorsal face accentuates the beveled appearance of the specimen. At least along two edges, the ventral surface under the beveled margins exhibits localized concentrations of short (3-5 mm) step fractured flake scars associated with crushed edges. The two remaining edges are beveled on their ventral face and the localized concentrations of step fractured flake scars are present on the artifact's dorsal surface. A number of flake scar ridges on both faces of the specimen are heavily polished suggesting that the specimen was somehow immobilized or hafted.

The second gunflint is a smaller $(29 \times 25 \times 7 \mathrm{~mm})$ finegrained chert specimen (Figure 23e). The blank appears to be the distal end of a hinge fractured tertiary flake. Steep unifacial beveling is present along one edge of the dorsal face of the specimen. Five to six flakes were removed off the ventral face of the flake using this beveled surface as the platform. The beveled edge lies opposite the hinge-fractured edge of the flake. The removals off the ventral face may have served to thin the flake along this edge. The presence of extensive localized crushing and step fracturing on the hingefractured margin suggests that this section served as the impact edge of the gunflint. Polish and rounding of flake scar ridges on the dorsal face of the specimen may also derive from its use as a gunflint. With the exception of one area on the dorsal face of the specimen, the crushing and step fracturing on the utilized edges of this specimen occur on the ventral face.

The remaining two specimens are recycled unifaces employed as gunflints. They have a roughly rectangular to circular shape obtained from heavy reworking either along three sides or the entire perimeter of the artifact. The larger of the two $(32 \times 27 \times 16 \mathrm{~mm})$ is a thick secondary flake with crushing and step fracturing along the two lateral and distal margins (Figure 23f). It has a single faceted platform and the blank was undoubtedly removed by a hard hammer stone percussor.

The other gunflint made of a recycled uniface (not pictured) is morphologically similar to the preceding artifact. Although it is somewhat smaller and lacks a striking platform, the specimen has been extensively retouched around its entire perimeter. Rounding, crushing, and step fracturing is evident over almost all of its entire distal edge and intermittently along one lateral edge.

\section{Cores}

Eight cores and core fragments have been identified. The analysis of the specimens indicates that in terms of approaches to core reduction and flake/blade production they can be divided into three groups. Group I consists of a single tested cobble. Group II consists of two split cobbles, while Group III contains two unidirectional flake/blade cores. The remaining three specimens are core fragments that may have been parts of multi-directional specimens.

The tested cobble is a somewhat coarse-grained pebble with a single flake removal. The coarse-grained material and imbedded fracture lines may have been reasons why it was abandoned. The two split cobble cores from Group II are medium-sized fine-grained chert cobbles that have been split either longitudinally or transversely. In the case of the smaller of the cores, the original break yielded a somewhat curved break surface, which was subsequently flaked to produce a flatter face. The splitting of the larger of the cores was initially attempted unsuccessfully through a transverse blow that plunged leaving a severely curved break surface. To flatten this surface, a longitudinally directed blow was delivered to one end of the core. This removal attempt proved unsuccessful causing step fracturing about $34 \mathrm{~mm}$ below the platform surface. If the splitting of the pebbles was intended to produce decorticate platform surfaces, the flake and/or blade cores that could have been produced from them would have ranged between $40-46 \mathrm{~mm}$ in length. Interestingly, even the smaller of the cores, that has a relatively flat decorticate surface was not used to produce the flake/blade blanks that are assumed to have been the intended final product. 
The Group III cores have a single decorticate platform surface produced by the "decapitation" of the pebble core. This platform surface is at one end of the pebble and flakes/blades are removed longitudinally from the core. The angle of the platform surface to the flake removals is 65 and 72 degrees, respectively.

\section{Unmodified Debitage}

A total of 229 unmodified debitage was recovered from excavations at $41 \mathrm{KA} 26-\mathrm{B}$. This number is significantly less than original field counts $(n=435)$ since a large number of lithic specimens that were initially identified as lithic debitage were reclassified as heat shatter or shatter generated by heavy machinery.

The breakdown of cortex categories among these specimens indicates that tertiary flakes constitute a slightly higher percentage than secondary flakes (Figure 24). Primary flakes represent a moderate proportion of the collection. Together, primary and secondary flakes constitute a higher percentage of the debitage than tertiary specimens. This pattern indicates that the raw material being reduced at the site was not decortified prior to its reduction. In addition, it also indicates that the reduction of the raw material did not proceed to the manufacture of finished tool forms. Rather, the cortex category trend suggests that lithic reduction focused on the manufacture of flake and/or blade blanks that were manufactured into finished tools at locations other than 41KA26-B. The distribution of debitage by size classes indicates that $11-20$ and 21$30 \mathrm{~mm}$ specimens dominate (Figure 25). The smallest size class $1-10$ $\mathrm{mm}$ ) may be under-represented because of the 1/4-inch hardware cloth used in screening. The size class distributions indicate a gradual decrease in the percentage of specimens in the larger size classes with increased size. The pattern does not necessarily suggest that small raw materials were being reduced at the site. Rather, the large proportion of small debitage probably derives from platform preparation activities associated with core reduction. A total of 122 (54\%) of the debitage collection consists of platform-bearing flakes and proximal fragments. Among these specimens, single faceted $(n=59,48 \%)$ and corticate $(n=51,42 \%)$ platforms are the dominant type (Figure 26). Only 12 $(10 \%)$ specimens have two or more platform facets. This pattern stands in strong contrast to debitage collections dominated by bifacial reduction, where multi-faceted striking platforms greatly outnumber corticate and single faceted specimens (Tomka 1989). These results indicate that bifacial reduction and biface manufacture was not a common activity at the site. Rather, it appears that most of the raw material
Figure 24. Distribution of debitage cortex categories.

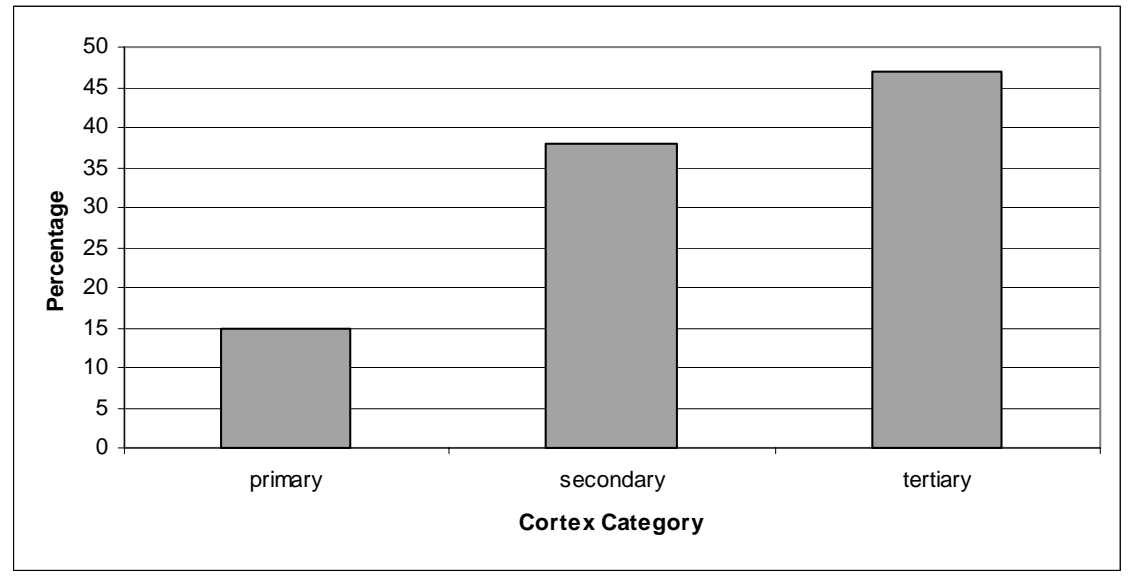

Figure 25. Distribution of debitage by size class.

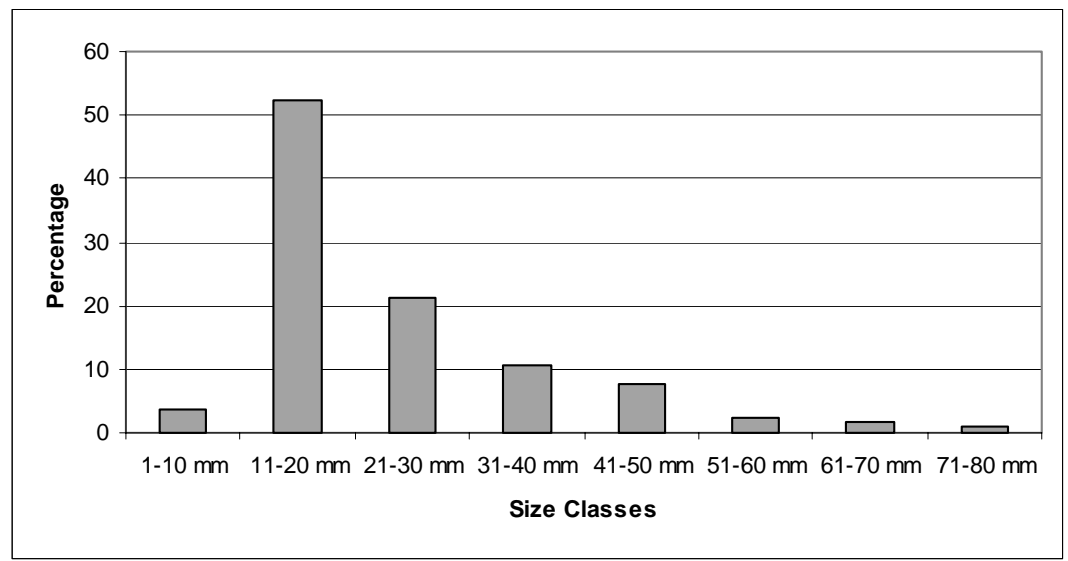


reduction concentrated on the production of flakes and blades from single faceted and/or corticate platform surfaces (e.g., corticate nodules and/or split pebbles). Finally, the breakdown of the debitage collection in terms of flake type indicates that core/platform preparation flakes constitute the largest proportion of the sample (Figure 27). Blades and uniface manufacture/resharpening flakes are infrequent, and as also noted before, only one (1\%) biface thinning flake was recognized in the collection. Viewed in combination, these debitage attributes suggest that most of these flakes derive from the preparation of uni- or bidirectional cores rather than bifacial core reductions (e.g., bifaces). In addition, it appears that on-site raw material reduction did not proceed beyond the manufacture of flake and blade blanks suggesting that these activities may have occurred at other sites.

Figure 26. Distribution of platform facet counts among platformbearing flakes.

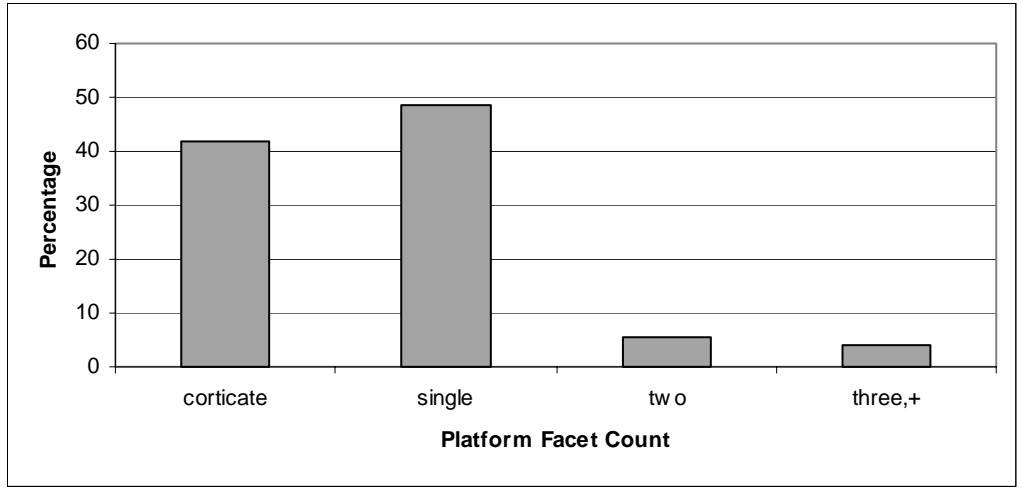

Figure 27. Distribution of debitage by flake type.

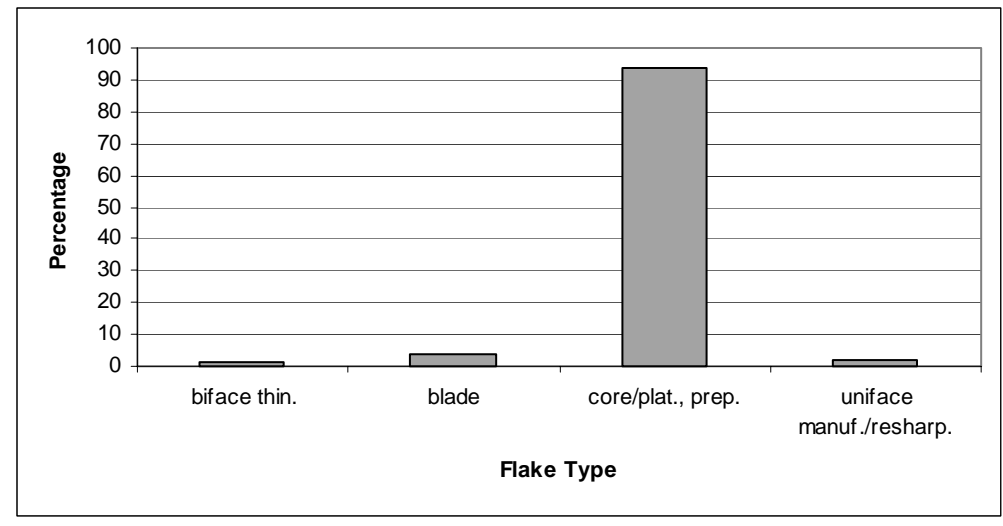

\section{Vertical Distribution}

The lithic debitage has a unimodal vertical distribution with debitage densities peaking in Level D $(30-40 \mathrm{~cm}$ bs; Figure 28). Sixty-eight percent of the lithic debitage occurs in Levels A-D, with only 34 percent found in the deeper levels. Debitage densities drop rapidly below Level E (40-50 cm bs). By themselves these debitage frequencies can tell us little about the possible number of components found at the site. Given that three components can be isolated in some parts of the site, the unimodal distribution may be indicative of a heavily bioturbated or otherwise disturbed occupation surface in Level D with debitage in higher and deeper levels being the result of bioturbation. On the other hand, although the lower densities of debitage in Levels $\mathrm{A}-\mathrm{C}$ and $\mathrm{E}-\mathrm{F}$ may indicate lithic reduction activities of a distinctly different character, such differences were not noted in the examination of the debitage by level.

The distribution of the small number of chipped lithic tools (Figure 28) shows a bimodal pattern with peaks in Levels B (10-20 $\mathrm{cm} \mathrm{bs)}$ and D (30-40 cm bs). These peaks roughly correlate with the two components identified within the Native American and Colonial period ceramic assemblages. The breakdown of the actual artifact categories indicates only two differences between the contents of the upper and lower zones. The Cuney point, and two of the three gunflints with known provenience are from the lower component (i.e., below $40 \mathrm{~cm}$ ). Secondly, six of the seven cores with known proveniences are also from the lower component. In light of these patterns, the lack of a second peak in debitage frequencies in Level B may simply mean that the occupations which produced the two possible components were of different durations and/or intensity (e.g., number of people involved). If this assessment is accurate, the discard of higher proportions of lithic tools versus lithic debitage would indicate a rather significant difference in the character of the activities carried out at the site. The 


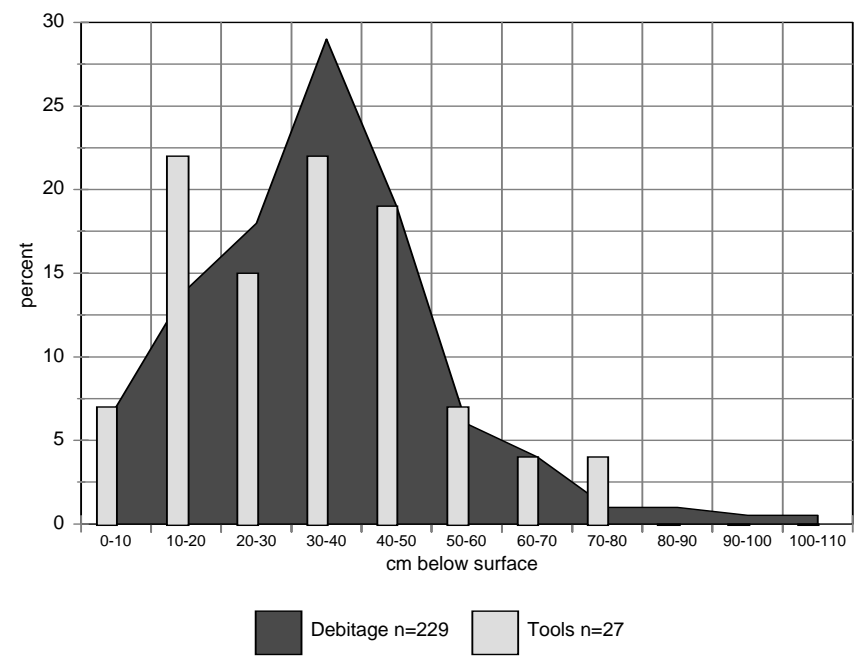

Figure 28. Vertical distribution of lithic artifacts.

relative proportions of tools and debitage suggest heavy tool use and discard and the manufacture of fewer replacement specimens in the upper component, in contrast to heavy tool use and discard accompanied by the manufacture of replacement specimens in the deeper component.

\section{Conclusions}

Overall, the lithic technology evident in the 41KA26B lithic artifacts indicates local or nearby raw material procurement, a tool kit composed primarily of expedient tool forms (e.g., scrapers), and the continued manufacture of stone arrow points even though metal points and guns had already been adopted. Raw material reduction strategies are dominated by uni-directional core reduction to produce blades and probably gunflint blanks. Bifacial reduction appears to be employed in arrow point manufacture and the shaping of some gunflint blanks. These aspects of the 41KA26-B lithic technology are similar to those noted at other mission sites occupied during the eighteenth and the nineteenth centuries (D. Fox 1979; Tomka 1999).

The richness and diversity of lithic tool forms is rather limited in this small sample size. However, a look at the range of tool forms recovered from Mission San José by a number of previous excavations (e.g., Clark 1978; Hard et al. 1995; Schuetz 1970; Tomka and Fox 1999) indicates a more diverse chipped stone assemblage consisting of "thumb-nail scrapers," minimally retouched end and side scrapers, a variety of edge-modified flakes (use worn but not retouched), spoke-shaves, gravers, perforators, indeterminate bifaces, arrow points, and gunflints. This range more accurately reflects the relative diversity of lithic tool forms that continued to be used by mission Indians and parallels the patterns noted by Hester $(1977,1982$, 1989 b) at the majority of the missions in south Texas.

The tool and debitage assemblages also indicate a de-emphasis on the manufacture of bifacial tool classes such as large knives. These patterns are in general agreement with patterns noted in many other parts of the country during the Late Prehistoric and Protohistoric periods (Parry and Kelly 1987; Sullivan and Rosen 1985). This shift from primarily bifacial reduction strategies to more expedient core technologies is attributed to decreased mobility (Parry and Kelly 1987:285). In addition, this assemblage composition pattern may also reflect the use, availability, and long use-life of metal knives and a relative lack of raw materials for the manufacture of metal arrow points. 



\section{Chapter 11: Vertebrate Fauna}

\section{Barnet Pavao-Zuckerman}

\section{Introduction}

Zooarchaeological materials from site 41KA26-B were studied. Site 41KA26-B was occupied from the middle eighteenth-to early-nineteenth century. Zooarchaeological evidence from this component indicates a reliance on terrestrial mammals, including a few European-introduced domesticates, supported by wild and domestic bird resources. It is unclear whether the domestic animals at the site indicate that animal husbandry was practiced, or if these individuals were acquired from the Spanish outpost.

\section{Methods}

The field work which produced the vertebrate samples from 41KA26-B was conducted between 1984 and 1985. A $1 / 4$-inch screen mesh was used to recover excavated materials. However, the upper $20 \mathrm{~cm}$ of each excavation unit often was discarded without screening. Faunal materials from 41KA26-B were excavated from four of the five features, and additional test units. A list of the proveniences containing the faunal remains is found in Appendix VII.

Vertebrate remains were identified using standard zooarchaeological methods. All identifications were made by Barnet Pavao-Zuckerman using the comparative skeletal collection of the Zooarchaeology Laboratory, Georgia Museum of Natural History, University of Georgia. A number of primary data classes are recorded, specimens are identified in terms of elements represented, the portion recovered, and symmetry and the Number of Identified Specimens (NISP) is determined. Those specimens that crossmended are counted as single specimens. The only exception is the UID Vertebrate category. Here the specimens are not counted due to their generally fragmented condition. All specimens are weighed to provide additional information about the relative abundance of the taxa identified. Indicators for sex, age at death, and modifications are noted where observed. Measurements are recorded following the guidelines established by Angela von den Driesch (1976) and are presented in Appendix VIII. The Minimum Number of Individuals (MNI) is estimated based on paired elements and age.

While MNI is a standard zooarchaeological quantification method, the measure has several wellknown biases. For example, MNI emphasizes small species over larger ones. This can be demonstrated in a hypothetical sample consisting of twenty squirrels and one deer. Although twenty squirrels indicate emphasis on the exploitation of squirrels, one deer would, in fact, supply more meat. Further, some elements are more readily identifiable than others. The taxa represented by these elements may therefore be incorrectly perceived as more significant to the diet than animals with less distinctive elements. Pig teeth, readily identified from very small fragments, exemplify this situation. Conversely, some taxa represented by large numbers of specimens may present few paired elements and hence the number of individuals for these species may be underestimated. Snakes and armadillo are good examples of this last problem. MNI for these animals will usually be underestimated relative to the number of specimens. Basic to MNI is the assumption that the entire individual was utilized at the site. However, from ethnographic evidence, it is known that this is not always true (Perkins and Daly 1968). This is particularly the case for larger individuals, animals used for special purposes, and where food exchange is an important economic activity (Thomas 1971; White 1953).

In addition to these primary biases, MNI is also subject to secondary bias introduced by the way samples are aggregated during analysis. The aggregation of archaeological samples into analytical units (Grayson 1973) allows for a conservative estimate of MNI, while the "maximum distinction" method, applied when analysis discerns discrete sample units, results in a much larger MNI. Primary data pertaining to materials from all excavated units, features, and test pits are combined for the estimation of MNI and other derived measures. 
Biomass estimates attempt to compensate for some of the problems encountered with MNI. Biomass refers to the quantity of tissue which a specified taxon might have supplied. Predictions of biomass are based on the allometric principle that the proportions of body mass, skeletal mass, and skeletal dimensions change with increasing body size. This scale effect results from a need to compensate for weakness in the basic structural material, in this case bone and teeth. The relationship between body weight and skeletal weight is described by the allometric equation (following Simpson et al. 1960:397):

$$
\underline{Y}=a \underline{X}^{b}
$$

In this equation, $\underline{X}$ is specimen weight, $\underline{Y}$ is the biomass, $\underline{b}$ is the constant of allometry (the slope of the line), and $\underline{a}$ is the Y-intercept for a log plot using the method of least squares regression and the best fit line (Casteel 1978; Reitz and Cordier 1983; Reitz et al. 1987; Wing and Brown 1979). Many biological phenomena show allometry described by this formula (Gould 1966, 1971) so that a given quantity of skeletal material or a specific skeletal dimension represents a predictable amount of tissue or body length due to the effects of allometric growth. Values for a and $\underline{b}$ are derived from calculations based on data at the Florida Museum of Natural History, University of Florida, and the Georgia Museum of Natural History. Allometric formulae for biomass estimates are not currently available for amphibians or lizards so biomass is not estimated for these groups.

The species identified from 41KA26-B are summarized in faunal categories based on vertebrate class. This summary contrasts the percentage of various groups of taxa in the collection. These categories are: Fishes, Snakes, Domestic Birds, Wild Birds, Deer, Other Wild Mammals, Domestic Mammals, Cow/Bison, and Commensal Taxa. In order to make comparisons of MNI and biomass estimates possible, the summary tables include biomass estimates only for those taxa for which MNI is estimated. However, in the case of bovids, biomass estimates for Bos sp., cf. Bos bison, and cf. Bos taurus are combined in the 41KA26-B summary table.
Taxa tentatively classified as commensal are frog/toad (Anura), mole (Scalopus aquaticus), armadillo (Dasypus novemcinctus), Old World rat (Rattus sp.), domestic cat (Felis domesticus), and horse/donkey (Equus sp.). While commensal animals might be consumed, they are commonly found in close association with humans and their built-environment. They are animals that people often either do not encourage or actively discourage. Armadillo are included as commensals in this analysis because they probably represent recent intrusions into the archaeological context. Armadillo are recent introductions into Texas and their range is still expanding eastward and northward in the Southeast today. The first recorded sighting of armadillos in the United States occurred in 1854 along the Rio Grande River (McBee and Baker 1982:2). As late as 1890, armadillos were reported to be rare in Eagle Pass, Texas, located in Maverick County on the Rio Grande River (Bailey 1905:53). Additionally, armadillos dig burrows as deep as 0.5 to 3.5 meters, and as long as 7.5 meters (Nowak 1991:165). Therefore, this animal could be intrusive at the 41KA26-B site.

Old World rat may have been consumed at the site; however, for interpretive purposes, it is more important to note the presence of this introduced pest species near Native American habitation areas than to assess its possible contribution to Native American diet. Domestic cat and horse/donkey are included as commensals because, although they too may have been eaten, their presence was most likely encouraged for reasons other than as a food resource. Cats could control pests, and equids could be used to carry burdens or for transportation.

The presence or absence of elements in an archaeological assemblage provides data on animal use such as butchering practices and transportation costs. The artiodactyl elements identified at 41KA26$\mathrm{B}$ are summarized into categories by body parts. The Head category consists only of skull fragments, including antlers and teeth. The atlas and axis, along with other vertebrae and ribs, are placed into the Vertebra/Rib category. It is likely the Head and Vertebra/Rib categories are under-represented because of recovery and identification difficulties. Vertebrae 
and ribs of deer-sized animals cannot be identified as deer or pig unless distinctive morphological features support such identifications. Usually they do not, and specimens from these elements are classified as UID Mammal, because a number of non-artiodactyls fall into the size-range of these medium-sized ungulates. Forequarter includes the scapula, humerus, radius, and ulna. Carpal and metacarpal specimens are presented in the Forefoot category. The Hindfoot category includes tarsal and metatarsal specimens. The Hindquarter category includes the innominate, sacrum, femur, and tibia. Metapodiae and podiae which could not be assigned to one of the other categories, as well as sesamoids and phalanges are assigned to the Foot category.

The elements identified for Artiodactyls from each analytical unit are presented visually to illustrate their number and location in a carcass. Loose teeth, tooth fragments, and antler fragments are not illustrated. Although the atlas and axis fragments are accurately depicted, other cervical, thoracic, lumbar and caudal vertebrae, as well as ribs, are placed approximately on the illustration. The last lumbar location is used to illustrate vertebrae which could only be identified as vertebrae. Specimens identified only as sesamoids, metapodiae, podials, or phalanges are illustrated on the right hindfoot.

The archaeological cat element data are also compared to a standard cat using a ratio diagram (Simpson 1941; Reitz and Zierden 1991) to determine if the burial was intentional. Described by George Simpson (1941; Simpson et al. 1960:357-358), the formula is as follows:

$$
\underline{\mathrm{d}}=\log _{\mathrm{e}} \underline{\mathrm{X}}-\log _{\mathrm{e}} \underline{\mathrm{Y}} \text { or } \underline{\mathrm{d}}=\log _{\mathrm{e}}(\underline{\mathrm{X}} / \underline{\mathrm{Y}})
$$

where $\underline{\mathrm{d}}$ is the logged ratio, $\underline{\mathrm{Y}}$ is percentage of each element category in the standard cat, and $\underline{X}$ is the same percentage of this category in the archaeological collections. It does not matter to what base the measurements are converted, though one should be consistent in order to remain comparable. As Simpson (1941:23) describes this approach:

$$
\begin{aligned}
& \text { The basic purpose of the diagram } \\
& \text { is to represent each of a number } \\
& \text { of analogous observations by a single } \\
& \text { entry and to plot them in such a way }
\end{aligned}
$$

\author{
that the horizontal distance between \\ any two of them will represent the ratio \\ of either one of those two to the other.
}

The standard cat is based on the number of elements present in an unmodified cat skeleton, excluding those elements not recovered in screen bias tests (Webber 1999). In order to compare the archaeological data with the standard cat, the percentages of each element category for the standard cat are converted into logarithms, subtracted from the logged value of the same element category for the archaeological percentages, and plotted against the standard cat represented by the vertical line in the accompanying figure (Figure 29). Although the archaeological values are specimen counts and the values for the standard cat are whole elements, the relationships in the ratio diagrams are similar to those found in unmodified histograms.

Relative ages of the artiodactyls and cat identified are estimated based on observations of the degree of epiphyseal fusion for diagnostic elements. When animals are young their elements are not fully formed. The area of growth along the shaft and the end of the element, the epiphysis, is not fused. When growth is complete, the shaft and the epiphysis fuse. While environmental factors influence the actual age at which fusion is complete (Watson 1978), elements fuse in a regular temporal sequence (Gilbert 1973; Purdue 1983; Schmid 1972). During analysis, specimens are recorded as either fused or unfused and placed into one of three categories based on the age in which fusion generally occurs. Unfused elements in the earlyfusing category are interpreted as evidence for juveniles; unfused elements in the middle-fusing and late-fusing categories are usually interpreted as evidence for subadults, though sometimes characteristics of the specimen may suggest a juvenile. Fused specimens in the late-fusing group provide evidence for adults. Fused specimens in the early- and middle-fusing groups are indeterminate. Clearly fusion is more informative for unfused elements which fuse early in the maturation sequence and for fused elements which complete fusion late in the maturation process than it is for other elements. An early-fusing element which is fused could be from an animal which died immediately after fusion was complete or many years later. The ambiguity inherent in age grouping is 
Figure 29. Log Ratio Diagram for archaeological cat elements compared to the modern standard.

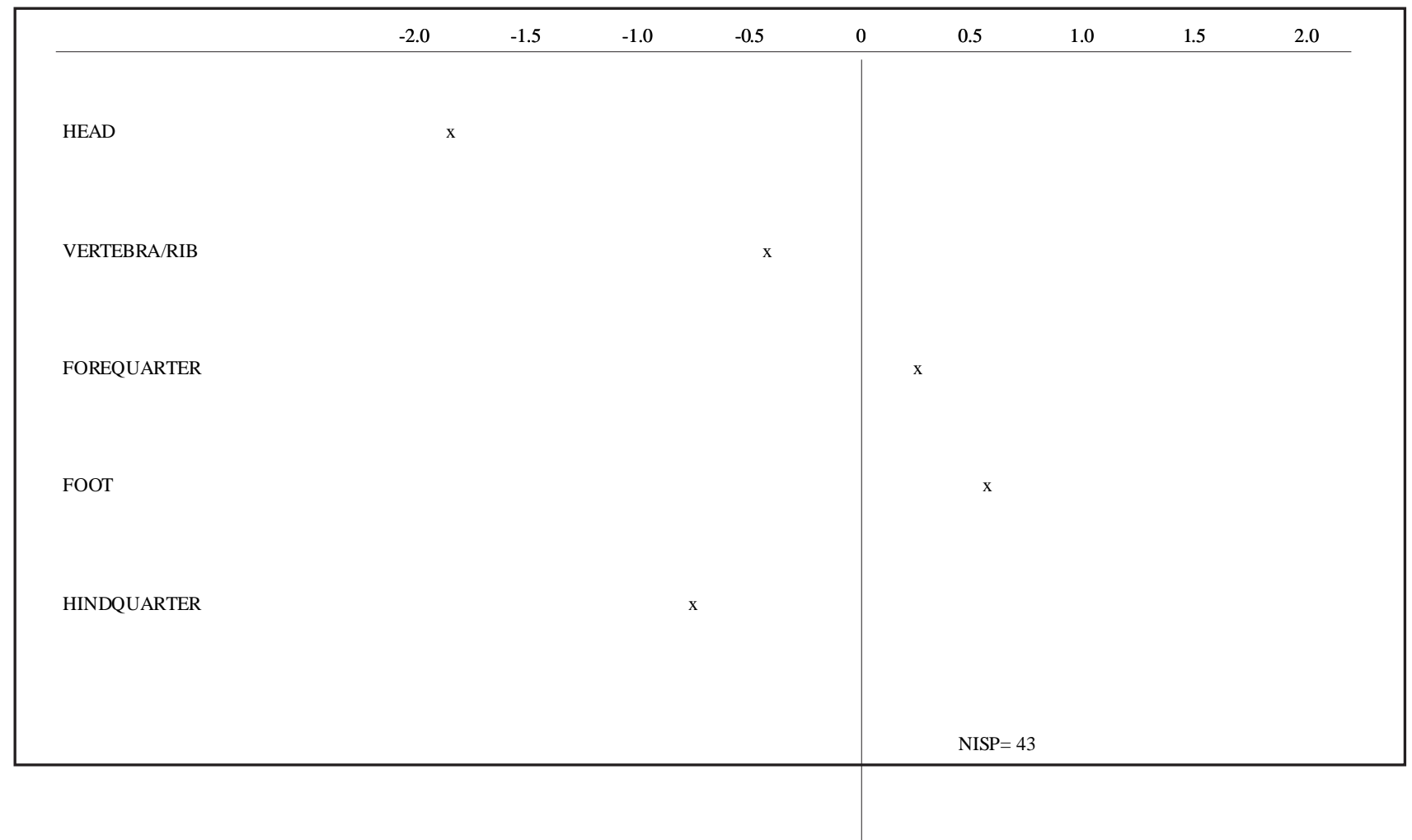

Log Ratio Diagram for archaeological cat elements compared to the modern standard (Webber 1999). Based on the formula $\underline{\mathrm{d}}=\log _{\mathrm{e}} \underline{\mathrm{X}}$ $\log _{\mathrm{e}} \underline{\mathrm{Y}}$; where $\underline{\mathrm{d}}$ is the logged ratio; $\underline{\mathrm{X}}$ is the element group in the archaeological sample; and $\underline{\mathrm{Y}}$ is the same element group in the standard.

somewhat reduced by recording each element under the oldest category possible. Tooth eruption data (Severinghaus 1949) are also recorded.

Cognizant of the strong probability that both cow (Bos taurus) and bison (Bos bison) were available to the residents of 41KA26-B, special attention was paid to the identification of large artiodactyl specimens. Comparative specimens as well as Balkwill and Cumbaa's (1992) guide to the identification of cow and bison post-cranial skeletons were used in identifying the large artiodactyl specimens. The Balkwill and Cumbaa guide provides the experimental success rate for several aspects of many bison and cow skeletal elements. Only a few of these aspects achieved a 100 percent success rate for identification of either bison or cow. For this reason, all bovid specimens from 41KA26-B are identified as "probable" cow or "probable" bison, noted as "cf." on the following species lists.
The sex of animals is an important indication of animal use; however, there are few categorical indicators of sex. Males are indicated by the presence of spurs on the tarsometatarsus of turkeys and antlers on deer. Male turtles are indicated by a depression on the plastron to accommodate the female during mating. Females are recognized by the absence of these features. Female birds may also be identified by the presence of medullary bone (Rick 1975). Another approach is to compare measurements of identified specimens for evidence of elements which fall into a male or female range, though there rarely are sufficient numbers of measurements to reliably indicate sex.

Modifications can indicate butchering methods as well as site formation processes. Modifications are classified as burned, calcined, and cut. Burned specimens may result from exposure to fire when a cut of meat is roasted. Burns may also occur if specimens are burned intentionally or unintentionally after discard. While NISP for specimens identified as UID Vertebrate is not included in the species lists, 
burned UID Vertebrate specimens are included in the modification tables. Burning at extreme temperatures can cause calcination and is usually indicated by bluegray discoloration. Cuts are small incisions across the surface of specimens. These marks were probably made by knives as meat was removed before or after the meat was cooked. Cuts may also be left on specimens if attempts are made to disarticulate the carcass at joints. Some marks that appear to be made by human tools may actually be abrasions inflicted after the specimens were discarded, but distinguishing this source of small cuts requires access to higher powered magnification than was available during the study (Shipman and Rose 1983).

Biomass, NISP, MNI, and other derived measures are subject to several common biases (Casteel 1978; Grayson 1979, 1981; Wing and Brown 1979). In general, samples of at least 200 individuals or 1,400 specimens are needed for reliable interpretations. Smaller samples frequently will generate a short species list with undue emphasis on one species in relation to others. It is not possible to determine the nature or the extent of the bias, or correct for it, until the sample is made larger through additional work.

Biomass, NISP, and MNI, also reflect identifiability. Elements of some animals are simply more readily identified than others and the taxa represented by these elements may appear more significant in terms of specimen count than they were in the diet. If these animals are identified largely by unpaired elements, such as scales and cranial fragments, the estimated MNI for these taxa will be low. At the same time, animals with many highly diagnostic but unpaired elements will yield a high specimen weight and biomass estimate. Hence high NISP, low MNI, and high biomass for some animals are artifacts of analysis. This source of bias is particularly critical to interpretations of the role of snake and armadillo in the subsistence strategies reflected in the 41KA26-B assemblage.

One method which addresses this bias by comparing variety and degree of specialization is to measure the diversity and equitability of the species identified from a site (Hardesty 1975; Reitz and Wing 1999). Diversity measures the number of species used. Equitability measures the degree of dependence on the utilized resources and the effective variety of species used at the site based on the even, or uneven, use of individual species. These indices allow discussion of food habits in terms of the variety of animals used at the site (richness or diversity) and the equitability (evenness) with which species were utilized.

To measure diversity, the Shannon-Weaver Index is used. The formula for the index is:

$$
H^{\prime}=-\sum p_{i} \log _{e} p_{i}
$$

where $\mathrm{p}_{\mathrm{i}}$ is the number of the ith species, divided by the sample size (Pielou 1966; Shannon and Weaver 1949:14). $\underline{P}_{\mathrm{i}}$ is actually the evenness component since the Shannon-Weaver Index measures both how many species were used and how much each was utilized.

Equitability is calculated using the formula:

$$
\mathrm{V}^{\prime}=\mathrm{H}^{\prime} / \log \mathrm{S}
$$

where $\underline{H}$ ' is the Diversity Index and $\underline{\log S}$ is the natural $\log$ of the number of observed species (Pielou 1966; Sheldon 1969).

Interpreting the indices can be difficult. Diversity increases as both the number of species and the equitability of species abundance increases. A diversity index of 4.99 is the highest possible value. A sample with many species identified, and in which the number of individuals slowly declines from most abundant to least abundant will be highly diverse. Diversity can be increased by adding a new taxon to the list, but if another individual of an already-present taxon is added, diversity is decreased. A low diversity can be obtained either by having a few species or by having a low equitability, where one species is considerably more abundant than others. A low equitability value indicates that one species was more heavily used than other species in the sample. A high equitability index, approaching 1.0, indicates an even distribution of species in the sample following a normal pattern where there are a few abundant species, a moderate number of common ones, and many rare ones. In the following discussion of vertebrate remains from 41KA26-B, diversity and equitability were calculated for MNI. Estimates of individuals were taken directly from the species lists. 


\section{Results and Discussion}

\section{KA26-B Results}

The 41KA26-B assemblage consists of a total of 1,111 identifiable specimens from a minimum of 27 individuals (Table 17). Two probable channel catfish (Ictalurus cf. punctatus) individuals were identified but these contribute only slightly to the biomass of the assemblage (Table 18). Both poisonous and nonpoisonous snakes are found in the assemblage and contribute more to the biomass of the assemblage than fish. One chicken contributes less to the biomass of the assemblage than fish. Three wild bird individuals were identified. One deer (Odocoileus virginianus) individual contributes 12 percent of the biomass for those taxa for which MNI was estimated (Tables 17 and 18). Several wild mammals other than deer were identified. This taxonomic category contributes 30 percent of the minimum number of identifiable specimens but only 1.6 percent of the biomass. Cow (Bos taurus) and bison (Bos bison) contribute two individuals to the assemblage and an estimated 78 percent to the biomass. Pig (Sus scrofa) is the other domestic mammal identified in the assemblage. This pig contributes 4 percent of the total MNI, but less than one percent of the biomass. Commensal taxa contributes 26 percent of the MNI and almost six percent of the biomass. The armadillo indicates a disturbed context in Test Units 25 and 37.

All elements identified as pig are from the Head (Table 19). Specimens identified as deer were identified from across the skeleton, with slightly more specimens identified from the Head and Foot categories (Table 19). Bovid elements are primarily from the Head, Foot, Hindfoot, and Hindquarter. Probable bison specimens are also fairly well distributed across the skeleton; however, no Head, Vertebra/rib, or Forefoot specimens were identified. Three phalanges were identified as probable domestic cow.

One of the cat individuals identified at 41KA26-B was less than nine months old at the time of its death, as evidenced by an unfused proximal femur (after Owens 1982). The other cat individual was at least 12 months old at death, indicated by a fused distal femur.

Although no evidence for fusion was noted in the pig assemblage, there are several deciduous premolars, and the ossification of several cranial elements is poor. This suggests that the pig individual was a juvenile at the time of death. The deer individual identified at 41KA26-B was an adult at the time of death. One bovid (Bos sp.) individual was less than 18 months old at the time of its death. The probable bison individual was at least 42 months old at the time of its death. The probable cow individual identified in the assemblage was at least 18 months old at death. The fusion data along with the possible identifications of cow and bison may indicate that three individuals contributed to the assemblage. However, given the uncertain nature of the bison and cow identifications, it is more conservative to estimate a MNI of two for all bovids (Bos sp., cf. Bos taurus, and cf. Bos bison).

A total of 105 burned specimens are present (Table 20). Greater than half of these modified specimens were identified as mammal. Two mammal specimens exhibit cut marks, and 32 specimens are calcined.

\section{KA26-B Discussion}

Site 41KA26-B is interpreted as a Native American and Spanish campsite occupied from the middle of the eighteenth century until the middle of the nineteenth century. Faunal remains indicate that the densest deposits occur from Levels $\mathrm{C}$ through E (20$50 \mathrm{~cm}$ ), corresponding to the eighteenth-century cultural zone identified by excavators. However, as noted above, the upper $20 \mathrm{~cm}$ of each excavation unit was often discarded without screening. Therefore, the specimen counts from 0-20 cm cannot be compared to counts from levels deeper than $20 \mathrm{~cm}$.

As shown in Figure 30, the majority of the faunal remains were recovered from units containing and associated with Feature 2 which is discussed separately in this section.

The faunal assemblage from this site is moderately diverse $\left(H^{\prime}=3.0884\right)$, but the equitability of the assemblage is very high $\left(\mathrm{V}^{\prime}=0.9850\right)$. The diversity of the assemblage is probably due to the high value for equitability. The residents of the campsite utilized equally a somewhat wide range of animal resources, with a focus on wild terrestrial mammals. The presence of only 12 fish specimens from the upper $30 \mathrm{~cm}$ of the site is surprising given $41 \mathrm{KA} 26-\mathrm{B}$ 's proximity to freshwater resources. However, a late prehispanic 
Table 17. Species List

\begin{tabular}{|c|c|c|c|c|c|}
\hline & \multirow{2}{*}{ NISP } & \multicolumn{2}{|c|}{ MNI } & \multirow{2}{*}{$\mathrm{Wt}, \mathrm{gm}$} & \multirow{2}{*}{ Biomass, $\mathrm{kg}$} \\
\hline & & $\#$ & $\%$ & & \\
\hline UID Fish & 3 & & & 0.415 & 0.0145 \\
\hline $\begin{array}{l}\text { Ictalurus cf. punctatus } \\
\text { (Probable channel catfish) }\end{array}$ & 9 & 2 & 7.4 & 4.319 & 0.0801 \\
\hline Anura (Frogs/toads) & 1 & 1 & 3.7 & 0.053 & \\
\hline Serpentes (Snakes) & 12 & & & 2.914 & 0.0407 \\
\hline Colubridae (Non-poisonous snakes) & 3 & 1 & 3.7 & 0.510 & 0.0070 \\
\hline Viperidae (Poisonous snakes) & 21 & 1 & 3.7 & 7.321 & 0.1031 \\
\hline UID Bird & 3 & & & 1.531 & 0.0301 \\
\hline Gallus gallus (Chicken) & 7 & 1 & 3.7 & 3.216 & 0.0591 \\
\hline Meleagris gallopavo (Turkey) & 2 & 1 & 3.7 & 22.210 & 0.3431 \\
\hline Zenaida sp. (Dove) & 1 & 1 & 3.7 & 0.053 & 0.0014 \\
\hline Toxostoma rufum (Brown thrasher) & 2 & 1 & 3.7 & 0.250 & 0.0058 \\
\hline UID Mammal & 830 & & & 945.872 & 12.5386 \\
\hline Didelphis virginiana (Opossum) & 27 & 2 & 7.4 & 13.840 & 0.2799 \\
\hline Scalopus aquaticus (Eastern mole) & 1 & 1 & 3.7 & 0.126 & 0.0041 \\
\hline Dasypus novemcinctus (Armadillo) & 2 & 1 & 3.7 & 3.742 & 0.0863 \\
\hline Sylvilagus sp. (Rabbit) & 8 & & & 1.975 & 0.0485 \\
\hline Sylvilagus aquaticus (Swamp rabbit) & 1 & 1 & 3.7 & 0.898 & 0.0239 \\
\hline Sylvilagus floridanus (Eastern cottontail) & 1 & 1 & 3.7 & 0.157 & 0.0050 \\
\hline Sciurus sp. (Squirrel) & 1 & & & 0.819 & 0.0220 \\
\hline Sciurus carolinensis (Gray squirrel) & 1 & 1 & 3.7 & 0.274 & 0.0082 \\
\hline Geomys sp. (Pocket gopher) & 1 & 1 & 3.7 & 0.307 & 0.0091 \\
\hline Rattus sp. (Old World rat) & 1 & 1 & 3.7 & 0.089 & 0.0030 \\
\hline Mustelidae (Weasel and skunk family) & 4 & & & 0.681 & 0.0186 \\
\hline Spilogale putorius (Spotted Skunk) & 13 & 2 & 3.7 & 3.736 & 0.0861 \\
\hline Felis domesticus (Domestic cat) & 43 & 2 & 7.4 & 49.750 & 0.8853 \\
\hline Large Ungulate & 17 & & & 38.273 & 0.6992 \\
\hline cf. Equus sp. (Probable Horse/donkey) & 1 & & & 17.988 & 0.3544 \\
\hline Equus sp. (Horse/donkey) & 1 & 1 & 3.7 & 25.942 & 0.4927 \\
\hline Artiodactyla & 7 & & & 8.037 & 0.1716 \\
\hline Sus scrofa (Pig) & 16 & 1 & 3.7 & 2.675 & 0.0638 \\
\hline Odocoileus virginianus (Deer) & 37 & 1 & 3.7 & 195.948 & 3.0404 \\
\hline Bos sp. (Bovid) & 24 & $(2)$ & & 501.283 & 7.0807 \\
\hline cf. Bos bison (Probable Bison) & 7 & 1 & 3.7 & 837.200 & 11.2343 \\
\hline cf. Bos taurus (Probable Cow) & 3 & 1 & 3.7 & 66.656 & 1.1520 \\
\hline UID Vertebrate & & & & 121.045 & \\
\hline TOTAL & 1111 & 27 & & 2880.105 & 38.9926 \\
\hline
\end{tabular}


Table 18. Faunal Summary

\begin{tabular}{|l|c|c|c|c|}
\hline \multirow{2}{*}{} & \multicolumn{2}{|c|}{ MNI } & \multicolumn{2}{c|}{ Biomass } \\
\cline { 2 - 5 } & $\#$ & $\%$ & $\mathrm{~kg}$ & $\%$ \\
\hline Fishes & 2 & 7.4 & 0.0801 & 0.3 \\
\hline Snakes & 2 & 7.4 & 0.1101 & 0.4 \\
\hline Domestic Birds & 1 & 3.7 & 0.0591 & 0.2 \\
\hline Wild Birds & 3 & 11.1 & 0.3503 & 1.4 \\
\hline Deer & 1 & 3.7 & 3.0404 & 12.1 \\
\hline Other Wild Mammals & 8 & 29.6 & 0.4122 & 1.6 \\
\hline Bison/Cow & 2 & 7.4 & 19.4670 & 77.7 \\
\hline Other Domestic Mammals & 1 & 3.7 & 0.0638 & 0.3 \\
\hline Commensal Taxa & 7 & 25.9 & 1.4714 & 5.9 \\
\hline TOT AL & 27 & & 25.0544 & \\
\hline
\end{tabular}

collection from the Lido Harbor site in Galveston County, Texas had a similar lack of fish remains (Weinstein 1991). The Lido Harbor site was excavated using one-quarter and one-eighth-inch waterscreens, with a ten percent sample of each level processed through a fine screen of one-sixteenthinch mesh. The screen size of the 41KA26-B assemblage and the unequal screening of contexts probably also contributed to the small fish sample size. If the catfish specimens in the assemblage are, indeed, channel catfish (Ictalurus punctatus), then it is not possible to determine whether these animals were captured in a freshwater or marine environment as the channel catfish regularly enters salt water (Hoese and Moore 1977:139).

A large number of snake vertebra were identified at the site, including both venomous and nonvenomous snakes. Although individuals from both families of snake were probably eaten, it is also possible that these specimens represent accidental inclusions into the site.

Turkey, dove, and brown thrasher were identified at the site. It is possible that these animals were acquired for reasons other than as a food resource. However, the large size of the turkey, and the moderate size of the dove and thrasher suggests that they were primarily taken as a source of food. These taxa do not provide any evidence suggesting season of capture.
Table 19. Identified Elements

\begin{tabular}{|l|c|c|c|c|c|c|}
\hline & Cat & Pig & Deer & Bovid & Bison & Cow \\
\hline Head & 2 & 16 & 12 & 11 & & \\
\hline Vertebra/Rib & 15 & & 1 & & & \\
\hline Forequarter & 7 & & 4 & 1 & 1 & \\
\hline Forefoot & 2 & & 2 & & & \\
\hline Foot & 3 & & 13 & 6 & 2 & 3 \\
\hline Hindfoot & 11 & & 2 & 4 & 3 & \\
\hline Hindquarter & 3 & & 3 & 2 & 1 & \\
\hline TOT AL & 43 & 16 & 37 & 24 & 7 & 3 \\
\hline
\end{tabular}

Table 20. Modified Elements

\begin{tabular}{|l|c|c|c|}
\hline & Burned & Calcined & Cut \\
\hline UID Mammal & 76 & 24 & 2 \\
\hline UID Vertebrate & 29 & 8 & \\
\hline TOTAL & 105 & 32 & 2 \\
\hline
\end{tabular}




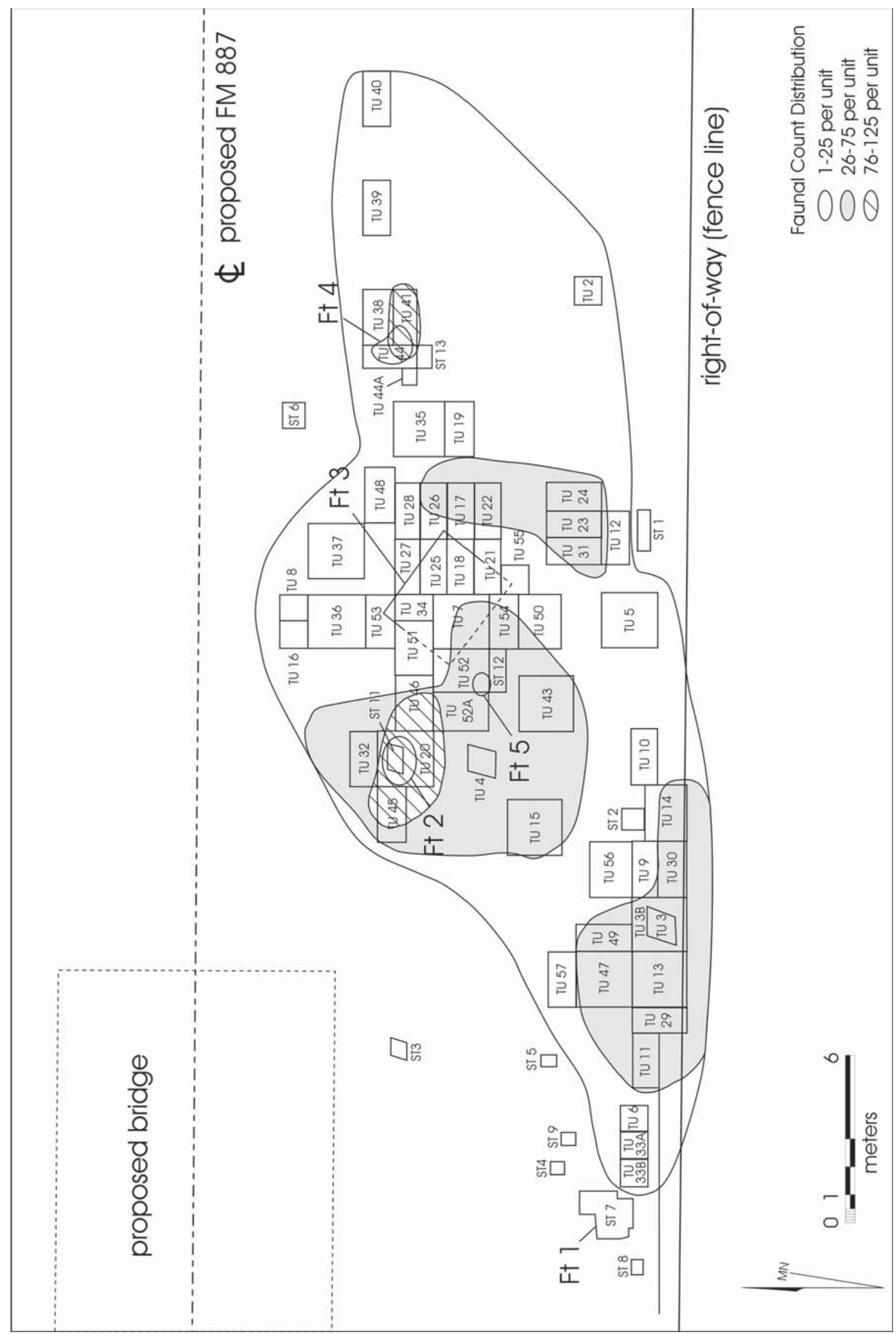

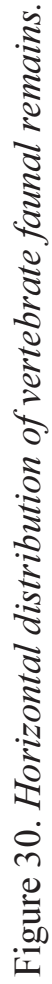


A wide range of non-domesticated terrestrial mammals was identified. Most of these animals are relatively small. The diversity and size of these mammals, other than bison, suggest that, for the most part, a generalist or chance encounter hunting technique was responsible for their capture. It is likely that these animals were taken when the opportunity presented itself, without a great deal of time dedicated to obtaining them.

Rabbits and opossum appear to have been important to the residents of the campsite. These taxa contribute only slightly to the biomass of the assemblage; however, the effort expended by the residents of the campsite to trap or net these animals could have been significant. These organisms are common at the site both spatially and temporally. Both animals are found in several different stratigraphic layers from several excavation units. Two species of rabbit were identified, including the eastern cottontail (Sylvilagus floridanus) and the swamp rabbit (Sylvilagus aquaticus). These two closely related animals inhabit different environments. The cottontail prefers brushy or forested areas, while the swamp rabbit is most commonly found in marshy bottomlands and takes readily to water (Burt 1980:208,212). This indicates that both upland and swampy environments were utilized by the residents of 41KA26-B.

The indeterminate frog/toad individual, included in the Commensal category, may have been eaten by the residents of the campsite, or may have been accidentally introduced.

Armadillos dig deep and extensive borrows and arrived in the United States only in the mid-nineteenth century (McBee and Baker 1982:2). Because both specimens were found within $10 \mathrm{~cm}$ of the surface of the site, it is likely that these specimens are of more recent origin than the occupation of the campsite. For these reasons, armadillo are placed in the Commensal category. An accidental death through burrow cave-in is not suggested by the data, however, as only two armadillo specimens were recovered. Additionally, these specimens were not located in close proximity to each other.

The one rat individual identified at the site may be either a black rat (Rattus rattus), or a Norway rat (Rattus norvegicus). In either case, this specimen represents an introduction of the rat into the New World by Europeans. Both of these animals are found almost exclusively in association with human habitations. Although it is possible that this individual was eaten, it is more likely that the rat specimen was an accidental inclusion. It was recovered from the top $20 \mathrm{~cm}$ of excavation.

Two spotted skunk individuals were identified. One individual was a juvenile at the time of its death. The animals may have been used both as a food resource and for fur. The spotted skunk remains were recovered from depths between 30 to $60 \mathrm{~cm}$.

The two cats are also European-introduced taxa. The completeness of both the kitten and cat skeletons suggests that these individuals were purposefully buried and do not represent the remains of a meal. Most of the cat specimens were recovered within the top $20 \mathrm{~cm}$ of the site. However, the log ratio diagram for cat was inconclusive regarding intentional burial (see Figure 29). These animals were probably more useful to the residents of the campsite as controllers of pests than as food. We cannot say to what extent these animals were treated as household pets, but it is likely that their presence was at the very least tolerated and was probably actively encouraged by the inhabitants of the site. The above statements, however, do not preclude the ultimate use of cats as a food resource after death. However, it is a more conservative interpretation to place this animal in the Commensal category of taxa.

Similarly, the horse/donkey individual was most likely primarily used as a pack animal or for locomotion than as a food resource. This animal is also a Europeanintroduced domesticate. It was not possible to tell from the specimen whether the individual was a horse, a donkey, or a mule. The individual's value as a beast of burden does not preclude its ultimate use as food. As with the cat, the horse/donkey is conservatively placed in the Commensal category of taxa. Both equid specimens were found in the levels of occupation corresponding to the eighteenth-century deposits identified during excavation.

Probable bison contributes substantially to the total biomass of the assemblage (see Table 17). The presence of the bison would indicate a degree of 
planning not necessary for the capture of smaller, less mobile, and less dangerous animals. Organized hunting of these large animals may have been the most important meat-procurement activity in terms of the amount of meat supplied per hunting incident. All probable bison bones were identified from Feature 2. The absence of certain skeletal element categories may indicate that the animal was butchered at the kill site and only usable parts were brought to the campsite. However, due to the difficulty of osteologically distinguishing bison and cow and the lack of modification data, and because of the small bison sample size, it is difficult to reach any conclusions concerning bison hunting and butchering behavior by the campsite's residents. The elements listed in Table 19 demonstrate that both high food utility and low food utility skeletal portions were recovered at 41KA26-B. The sample size is quite small, however, the recovered elements may suggest that some large bovid individuals were butchered at the site.

Deer also appear to have been important to the diet at 41KA26-B. This taxon alone contributes almost 12 percent of the biomass of the assemblage (Table 18). The skeletal element distribution suggests that deer were brought whole to the site and butchered there. The scarcity of vertebra and rib elements probably reflects the low identifiability of these elements rather than any human butchering activity. This interpretation is supported by the presence of low utility items such as the Forefoot, Foot, and Hindfoot categories. Deer remains are fairly well distributed across the site. A small concentration of deer phalanges and a metacarpal in Test Unit 35 between $30-40 \mathrm{~cm}$ is the only obvious pattern or cluster to the deer skeletal assemblage. This may indicate that this area of the site was used as a primary butchering area for deer.

Three domestic animal individuals were identified at the site. One chicken, one pig, and one probable cow were identified. Chicken elements are identified from a depth of 10-70 cm, suggesting that the species was introduced early in the site's history. All pig specimens, including only teeth, were identified in the upper 10 $\mathrm{cm}$ of the site. This animal does not appear to have contributed substantially to the diet of the residents of the campsite. In terms of biomass contribution, domestic mammals and birds fall behind even the Commensal category. However, the difficulty of distinguishing between cow and bison based on osteology has probably resulted in reducing the biomass contribution of cows to the assemblage. The three probable cow specimens were not found in close proximity to each other. Two of the probable cow specimens were found within the top $20 \mathrm{~cm}$ of the site and may represent recent inclusions. There is not enough evidence to demonstrate that the residents of 41KA26-B were raising domestic animals, rather than acquiring animals or meat from their Spanish neighbors.

\section{Feature 2 Results}

Approximately a third of NISP of the 41KA26-B component is contributed by a single feature (Feature 2) interpreted in the field as a refuse dump. Excavators noted a bone and artifact concentration located between $20-50 \mathrm{~cm}$. It is for these reasons that this feature will be considered separately.

A total of 333 identifiable specimens were recovered from Feature 2 (Table 21). Just over 22 percent of the total 41KA26-B MNI is contributed by Feature 2. Over 50 percent of the total bone weight and biomass of the $41 \mathrm{KA} 26-\mathrm{B}$ assemblage is also contributed by this feature. The species list for Feature 2 is slightly different from the total assemblage. Snake (Serpentes; Viperidae), dove (Zenaida sp.), opossum (Didelphis virginiana), deer (Odocoileus virginianus), and bovid (Bos sp.; cf. Bos bison, cf. Bos taurus) are the only taxa identified in the Feature 2 assemblage. Only a single deer specimen was identified in the Feature 2 assemblage. Bovid specimens from Feature 2 total over one half of the total number of bovid specimens identified in the 41KA26-B assemblage. Bovids contribute the bulk of the weight and biomass of the sample; however, opossum contributes the highest number of identifiable specimens. Most of the opossum specimens in the total assemblage were excavated from Feature 2, as was the only dove specimen. No commensals such as rodents, domestic cats, or horse/ donkey were identified in the Feature 2 assemblage. 
Table 21. Species List from Feature 2

\begin{tabular}{|c|c|c|c|c|c|}
\hline & \multirow[b]{2}{*}{ NISP } & \multicolumn{2}{|c|}{ MNI } & \multirow{2}{*}{$\begin{array}{l}\text { Weight, } \\
\text { gm }\end{array}$} & \multirow{2}{*}{$\begin{array}{l}\text { Biomass } \\
\quad \mathrm{kg}\end{array}$} \\
\hline & & $\#$ & $\%$ & & \\
\hline Serpentes & 4 & & & 1.445 & 0.02 \\
\hline Viperidae & 21 & 1 & 16.7 & 7.321 & 0.1031 \\
\hline Zenaida sp. (Dove) & 1 & 1 & 16.7 & 0.053 & 0.0014 \\
\hline UID Mammalia & 261 & & & 406.704 & 5.8661 \\
\hline Didelphis virginiana (Opossum) & 24 & 1 & 16.7 & 12.411 & 0.2538 \\
\hline Artiodactyla & 2 & & & 2.146 & 0.0523 \\
\hline Odocoileus virginianus (Deer) & 1 & 1 & 16.7 & 7.254 & 0.1565 \\
\hline Bos sp. (Bovid) & 11 & (1) & & 184.924 & 2.886 \\
\hline cf. Bos bison (Probable Bison) & 7 & 1 & 16.7 & 837.2 & 11.2343 \\
\hline cf. Bos taurus (Probable Cow) & 1 & 1 & 16.7 & 16.106 & 0.3208 \\
\hline UID Vertebrate & & & & 37.522 & \\
\hline TOTAL & 333 & 6 & & 1513.086 & 20.8943 \\
\hline
\end{tabular}

\section{Feature 2 Discussion}

The Feature 2 assemblage can probably be best interpreted as a refuse pit that was quickly filled and covered. The lack of rodent remains in the Feature 2 assemblage, in contrast to the rest of the 41KA26-B assemblage, suggests that the feature was not exposed for very long before being covered. However, the feature contains a larger number of taxa than one would expect for a refuse pit used for a brief time. For these reasons, and also because all probable bison specimens were identified in this single feature, it is possible that Feature 2 is the result of a single large event such as a feast. However, there is not enough information at this time to positively determine the function or time-depth of Feature 2.

\section{Conclusion}

Although increasing the sample size of the 41KA26$\mathrm{B}$ assemblage would be beneficial, we can make some inferences concerning human behavior at this site. It appears that the residents relied mainly on terrestrial mammal resources, supplemented by wild and domestic birds, with very little reliance on aquatic resources. Chicken, and most likely cattle, were found at the site, however, there is insufficient evidence to determine if these animals represent the practice of animal husbandry at the site. It is also likely that bison were used by residents of the site.

The densest deposits of animal bone correspond to the eighteenth-century deposits identified during the excavation of the site. Faunal remains indicate that Feature 2 may have been a short-term refuse pit that was not exposed for any great length of time. 


\section{Chapter 12: Summary and Conclusion}

In advance of a bridge-widening project on FM 887 at Cibolo Creek, TxDOT archaeologists conducted a data recovery investigation at $41 \mathrm{KA} 26-\mathrm{B}$. This site is located on the south side of the highway on a terrace situated on the east side of the creek. Forty-five test units and seven shovel tests were excavated resulting in the recovery of approximately 4000 artifacts including over 1000 pieces of animal bone, 445 Native American pottery sherds, 404 pieces of Spanish ceramics, and 256 lithics. Five features were identified. These include a faunal refuse dump (Feature 2) containing bison and cattle remains, a Native American ceramic dump (Feature 5), and the remnants of an early-nineteenth-century jacal structure (Feature 3).

The sequence of natural stratigraphy across the site indicates three levels of occupation are present. From 0-30 $\mathrm{cm}$ the modern A horizon and the underlying lighter strata consist of dark gray-brown loamy sand and yellowish gray-brown silty sand. Beginning 30-32 $\mathrm{cm}$ bs and continuing to a depth of $50-60 \mathrm{~cm}$ bs another brown to grayish brown loamy sand layer is present which represents an earlier living surface. This is again followed by a light brown silty sand layer below $60 \mathrm{~cm}$.

The depositional episodes at the site appear to have accumulated over a 100 year span $(1730 \mathrm{~s}-1830 \mathrm{~s})$ toward the end of the Spanish Colonial period. With this site's strategic location on a terrace above a permanent ford of Cibolo Creek, it is possible that, even in pre-Colonial times it was a favored encampment location for travelers waiting to cross. However, there is no evidence of these earlier occupations in the recovered material. Although artifacts were recovered from depths in excess of $60 \mathrm{~cm}$ in three test units and one shovel test excavated during this investigation, in these deepest deposits, Spanish Colonial period leadglazed sherds were present along with bone-tempered Native American ceramics, lithic material, and the Late Prehistoric-Historic period Cuney point indicating, at best, an early Colonial period date for these deepest deposits. With the exception of some vertical mixing in one portion of the site, the depositional context of the vertical stratigraphy of archeological deposit is intact, occurring on a depositionally dynamic landform near a volatile creek where discrete vertical contexts are possible.

While the overall vertical concentration of artifacts occurs between $20-50 \mathrm{~cm}$ bs, some differences can be seen between the artifact types and frequencies within the depositional episodes. The few diagnostic artifacts recovered from the $0-30 \mathrm{~cm}$, or upper component include military buttons from 1837, a knife dated ca. 1835 , and assorted rifle and pistol balls. These artifacts suggest a late-Colonial period, early- to mid-nineteenth century time period for this occupation. Between 6573 percent of the sparse to moderate bone-tempered Native American ceramic assemblage came from this upper component while profusely bone- tempered and sandy paste sherds dominated the $30-60 \mathrm{~cm}$ deposit. Similarly, over 58 percent of the lead-glazed Spanish ceramics were recovered from the upper $30 \mathrm{~cm}$ while non-Native unglazed sherds were proportionally more prominent below $30 \mathrm{~cm}$. Differences in the relative proportions of tools and debitage in the two components suggest heavy tool use and discard, and the manufacture of fewer replacement specimens in the upper levels, in contrast to the heavy tool use and discard accompanied by the manufacture of replacement specimens found in the lower component.

These contrasts in frequencies may offer a set of characteristics to define early versus late Colonial period artifact assemblages in south central Texas. The earlier assemblage is characterized by profuse bone-tempered and sandy paste Native American ceramics, unglazed non-Native wares, and stone tool manufacture. The upper, and therefore later Colonial period assemblage contains Native American sherds with sparse to moderate amounts of bone temper, high frequencies of lead-glazed Spanish ceramics, and decreased evidence of actual stone tool manufacture.

Horizontally, artifact concentrations were identified in three areas of the site. Thirty-two percent of the lead-glazed sherds and over 50 percent of the faunal 
weight and biomass from the site comes from Feature 2. The concentration of Native American sherds in Feature 5 accounts for nine percent of the site assemblage. The heaviest concentrations of non-feature related artifacts occurs in the southwest quadrant of the site in units located along the southern edge of the TxDOT ROW. Over 60 percent of the entire ceramic assemblage and 42 percent of the lithic collection was concentrated in these 17 units. Refits of transfer printed sherds recovered from between $10-60 \mathrm{~cm}$ bs in five units in this quadrant indicates a substantial degree of vertical mixture occurred along the fence line.

With the founding of El Fuerte del Cibolo and the establishment of the La Bahía road connecting Spanish missions and settlements in San Antonio and Goliad, traffic increased at the Carvajal Crossing. The artifacts indicate the area was being frequented by both Native Americans and Spanish travelers during the mid- to late-eighteenth century. Almost equal amounts of Native and non-Native ceramic sherds occur together in units and levels across the site along with lithic material and animal remains, suggesting a series of small, overlapping occupations. The relatively low density of artifacts recovered during the project indicates that none of the occupations extended for any length of time.

Analysis of the faunal material suggests occupants of the campsites utilized a wide range of animal resources, with a focus on wild terrestrial mammals, some of which were butchered at the site. The mixture of probable cow along with probable bison and deer in the faunal concentration in Feature 2 illustrates the variety of domestic and wild mammals utilized by both Native and European travelers during the Colonial period. But again, the low number of individuals identified in the collection indicates short-term, transient occupations. The seven commensal, or nonfood taxa probably represent more modern intrusions into the site.

The early- to mid-nineteenth century occupation is represented by the 1837 Republic of Texas Dragoons buttons, the ca. 1835 Green River knife, glass trade beads, and an assortment of lead rifle and pistol balls. The knife, one of the buttons, and all but one of the glass beads were recovered from the living surface associated with Feature 3. The function of this jacal however, remains problematic. It was suggested in the testing report (Goode 1984) that the jacal could have been associated with the Apaches connected with the fort. The age and type of artifacts with affinity to this feature seem to rule out this interpretation -as the fort was abandoned for the last time in 1782 (Thonhoff 1992). There is an account of a Lipan Apache camp near the crossing on the east side of the creek during the Carvajal occupation of the area in the $1830 \mathrm{~s}$, and another report of a small trading post owned by George Rhyme somewhere near the crossing ca. 1840. While these occupations, both reported by Thonhoff (1964), would seem to fit with the artifacts, details of their locations or actual existence cannot be verified.

Despite the modern disturbances evident in portions of the site, 41KA26-B contains a stratified sample of cultural materials representative of late-eighteenth and early-nineteenth century life in south central Texas. This site was initially identified as a campsite used intermittently by transient Indian groups during the eighteenth century, possibly because of its proximity to the Spanish fort, El Fuerte del Cibolo (Goode 1984). Analyses of the information and cultural material obtained during the data recovery investigations at the site support this initial interpretation while broadening the cultural identifications of the peoples who used this camping site, and clarifying the periods of utilization/occupation.

\section{Research Questions}

\author{
Timothy K. Perttula, Steve A. Tomka, \\ and Cynthia L. Tennis
}

Two areas of interest concerning the effects of colonization on the Native American material-culture traditions were identified at the start of this reporting project to serve as larger research issues for the south Texas area. These research questions, or hypotheses, are addressed below. The prospect of determining ethnic or cultural affiliations through Native ceramics in this part of the state is also considered. 


\section{Question 1:}

Frontier Supply System and its Effect on Native Technology - What was the nature of the frontier supply system in Texas between ca. 1730-1830, and what effect did changes in the system have on Native American technology?

It is known that bone-tempered plain pottery was manufactured by Native American groups - particularly the Aranama (see Mounger 1959:179-180) and the Tamique (see Walter 1997) - at Mission Espíritu Santo de Zúñiga at Goliad, and then "sold to the residents of the secular La Bahía community" (Ricklis 1999b, based on Cardenas [1783]). It is possible that these mission ceramic wares were produced for sale outside the La Bahía community, as well as traded for produce (i.e., hides and furs) with Native American groups living well outside the mission community.

The identification of sherds at contemporaneous nonmission sites from vessels manufactured in mission contexts will have to rely on both petrographic and chemical compositional analyses of sherds from mission and non-mission aboriginal sites, and at the present time, information is not in hand that can document the scope and tempo of this aspect of frontier trade. It is the case that a few sherds from 41KA26-B appear to be from both sandy paste and bone-tempered vessels that were not manufactured locally, however, the manufacturing locale or locales have not been determined.

Lower amounts of asphaltum-coated sherds in the upper component at Carvajal Crossing may indicate a more limited access by inland coastal aboriginal groups to sources of asphaltum, and that "interaction among Native ethnic groups was probably more restricted [in the mid-to-late eighteenth century] than during aboriginal times. This may reflect social constraints imposed by the organizational structure of the Spanish Colonial system" (Ricklis 1999a:164). The lower frequencies of asphaltum may also simply indicate that different means of interior vessel surface treatment (i.e., such as smoothing or burnishing to lower the permeability of the vessels) were in use at the site that had no relation to interaction with coastal groups, or to mission-influenced ceramics. As previously noted, only 10-20 percent of the sherds from inland coastal Toyah phase components have asphaltum-coated surfaces. This indicated the existence of other more common forms of surface treatment in these sites, and a technological and temporal continuity between prehistoric inland coastal Toyah ceramics and the eighteenth century ceramics from Carvajal Crossing.

As mentioned earlier, the dominance of expedient specimens within the lithic assemblage at the site may reflect some degree of sedentation in the aboriginal population. In this respect, the lithic technology may be a direct reflection of the impact of mission and Spanish influence. On the other hand, the dominance of expedient tool forms may also result from the impact of Spanish material culture upon aboriginal technology. Specifically, the addition of more reliable and longer-use-life metal tools to the aboriginal repertoire may have decreased the need for the manufacture of more "expensive" formal stone tool forms such as bifacial knives, and end scrapers.

The recovery of four probable gunflints from the site perhaps signals the beginning of the end of the traditional bow and arrow hunting technology. Because early guns were less reliable and aboriginal populations did not posses the technology to maintain and repair broken guns, their adoption was less rapid. In contrast, however, the adoption of other tools such as metal knives and cooking wares was less dependent on their maintainability and repair technology, and therefore occurred more readily and rapidly. This scenario suggests that the earliest changes in aboriginal technology should show up in the declining presence of exactly those tools forms that are lacking at 41KA26-B (e.g., formal knives, end scrapers). The replacement of projectile points, however, should lag behind given the questionable reliability of the alternative Spanish hunting technology.

\section{Question 2:}

Effect of Spanish Influence on Native American Ceramic Technologies - How did Spanish colonization influence Native American ceramic technologies?

The manufacture of Native American ceramics at 41KA26-B does not appear to have been particularly influenced in any fashion by the colonization of this part of south Texas by the Spanish missionaries, 
soldiers, and settlers which began in the early eighteenth century. The ceramic assemblages at the site are clearly derived from indigenous aboriginal ceramic plain wares made since ca. A.D. 1200/1300 that had bone-temper in varying amounts. There are no Spanish-inspired vessel forms (i.e., candle holders, spoons, whistles, or pottery rests; see Mounger 1959), and the vessels present appear to be from cooking jars and serving bowls.

The differences between the upper and lower ceramic components in the amount of bone added to the clay paste, and in the proportion of sherds with asphaltum coatings do suggest that there were changes in the ceramic technology. These changes were not broad sweeping technological changes, but rather proportional differences based on adding lesser amounts of bone to paste-perhaps related to the length of firing times and differences in firing conditions - and using asphaltum with less frequency as a interior vessel coating. There do not appear to be any differences in the types of vessels being made and used at Carvajal Crossing when compared to bonetempered ceramic wares on Prehistoric and Protohistoric inland coastal prairie Toyah phase sites.

As mentioned above, limited access to asphaltum sources following the establishment of Spanish missions in southern Texas may have led to a lower availability of this coastal resource, but other explanations may account for a lesser use, including:

(1) Other forms of effective interior vessel surface treatment; and

(2) Perhaps changes in the prevalent movements of inland coastal prairie aboriginal groups away from the Spanish missions.

\section{Question 3:}

Ethnic or Cultural Affiliations of the Ceramics - Can ethnic or cultural affiliation of the Native American groups at 41KA26-B be determined through the ceramic assemblage?

With respect to the possible cultural and/or ethnic affiliation of the Native American group or groups that lived or camped at the Carvajal Crossing site (41KA26-B), Thonhoff (1992:15) had suggested that the "Pataguillas [sic] were the primary Indians of the ranch belonging to Mission San Juan Capistrano which occupied much of El Rincon in the eighteenth century." El Rincon refers to the wedge-shaped piece of land between the San Antonio River and Cibolo Creek in Karnes and Wilson counties, Texas (Thonhoff 1992:2). However, Campbell (1996:87) notes that the name "Pataquilla" refers to a lake in "the vicinity of presentday Panna Maria in Karnes County," not to a Native American group. He goes on to say that " $[\mathrm{n}] \mathrm{o}$ Indians at San Juan Capistrano Mission, or anywhere else in Texas, were ever identified as Pataquilla."

There is no evidence in the Carvajal Crossing ceramics that hint at a Karankawan ethnic affiliation for the Native American occupants responsible for the manufacture and eventual discard of the broken ceramics at the site, even though sandy paste ceramics with asphaltum-coated surfaces are present in moderate amounts. First, the proportions of sandy paste and asphaltum-coated sherds are quite low compared to the Rockport ceramics found on Prehistoric and earlyHistoric Karankawan sites along the central Texas coast, or on the late seventeenth century to early eighteenth century Keeran site on Garcitas Creek (Gilmore 1973), or to the proportion of asphaltum-coated and decorated sherds at Mission Rosario (see Ricklis 1995b, 1998, 1999a). Second, none of the sherds with asphaltum have Rockport Black on Gray I or II decorations. And, finally, the amount of moderate- to profusely-bone-tempered ceramics is much more comparable to inland coastal prairie Toyah phase components, and to the ceramics at Mission Espíritu Santo at Goliad, than it is to any Rockport phase components. Therefore, the ceramics from the Carvajal Crossing site are most appropriately affiliated with Native American groups that lived on the inland coastal Plain of central and southern Texas, and were related to "Late Prehistoric and Protohistoric Indian groups [that] were making bone-tempered ceramics ... and some of these groups were present in the mission populations" (Hester 1989b:224). 


\section{References Cited}

Albert, A. H.

1969 Record of American Uniform and Historical Buttons. Boyertown Publishing Company, Boyertown, Pennsylvania.

Albert, L. S., and K. Kent

1949 The Complete Button Book. John Edwards, Stratford, Connecticut.

Andrews, S. L.

1981 Archeological Survey and Assessment Along Segments of Overhead Power Line Right-of Way in Atascosa, Karnes, and McMullen Counties, Texas. Report of Investigations No. 6. Prewitt and Associates, Austin.

Arman, D., and L. Arman

1977 Historical Staffordshire: An Illustrated Check-List, First Supplement. Arman Enterprises, Danville, Virginia.

Bailey, V.

1905 North American Fauna No. 25: Biological Survey of Texas. United States Department of Agriculture Biological Survey, Washington, D.C.

Balkwill, D. M., and S. L. Cumbaa

1992 A Guide to the Identification of Postcranial Bones of Bos taurus and Bison bison. Syllogeus No. 71. Canadian Museum of Nature, Ottawa, Ontario.

Barnes, M. R.

1980 Mexican Lead Glazed Earthenwares. In Spanish Colonial Frontier Research, complied and edited by H. F. Dobyns. Spanish Borderlands Research 1. Center for Anthropological Studies, Albuquerque.

Baugher-Perlin, S.

1982 Analyzing Glass Bottles for Chronology, Function, and Trade Networks. In Archaeology of Urban America: The Search for Pattern and Process, edited by R. S. Pickens, pp. 259-289. Academic, New York.

Black, S. L.

1989 South Texas Plain. In From the Gulf Coast to the Rio Grande: Human Adaptation in the Central, South, and Lower Pecos Texas, by T. R. Hester, S. L. Black, D. G. Steele, B. W. Olive, A. A. Fox, K. J. Reinhard, and L. C. Bement, pp. 39-62. Research Series 33. Arkansas Archeological Survey. Fayetteville.

1995 Archaeological and Ethnohistoric Background. In Archeological Investigations at the Loma Sandia Site (41LK28). A Prehistoric Cemetery and Campsite in Live Oak County, Texas, by A. L. Taylor and C. L. Highley, pp. 31-45. Studies in Archeology 20. Texas Archeological Research Laboratory, The University of Texas at Austin.

Blair, W. F.

1950 The Biotic Provinces of Texas. Texas Journal of Science 2(1):93-117. 
Bolton, H. E.

1915 Texas in the Middle Eighteenth Century: Studies in Spanish Colonial History and Administration. Texas State Historical Association, University of Texas press, Austin.

Brinckerhoff, S. B., and O. B. Faulk

1965 Lancers for the King. Phoenix Press, Phoenix.

Brown, K. M.

1987 Early Occupation at Berger Bluff, Goliad County, Texas. Current Research in the Pleistocene 4:3-5.

Burt, W. H.

1980 A Field Guide to the Mammals. Houghton Mifflin Company, New York.

Campbell, T. N.

1996 Pataquilla Indians. In The New Handbook of Texas, Volume 5, edited by R. Tyler, D. E. Barnett, R. R. Barkley, P. C. Anderson, and M. F. Odintz, p. 87. Texas State Historical Association, Austin.

Carlson, S. B.

1994 Texas Beyond the Periphery: An Archaeological Study of the Spanish Missions During the 18th Century. Ph. D. dissertation, Texas A\&M University, College Station.

Cargill, D. A., and R. J. Hard

1999 Assessing Native American Mobility versus Permanency at Mission San Juan Capistrano through the Use of Stable Isotope Analysis. Bulletin of the Texas Archeological Society 70:197-213.

Castañeda, C. E.

1936 Our Catholic Heritage in Texas, 1519-1936. Vol. IV. Texas Knights of Columbus Historical Commission, Austin.

1976[1942] Our Catholic Heritage in Texas. Vol. V. Texas Knights of Columbus Historical Commission. Von Boeckman-Jones Company. Austin.

Casteel, R. W.

1978 Faunal Assemblages and the "Wiegemethode" or Weight Method. Journal of Field Archaeology 5:72-77.

Chabot, F. C.

1937 With the Makers of San Antonio. Privately Published, Artes Graficas, San Antonio.

Chipman, D. E.

1992 Spanish Texas, 1519-1821. University of Texas Press, Austin.

Clark, J. W., Jr.

1978 Mission San José y San Miguel de Aguayo: Archeological Investigations, December 1974. Archeological Report 29. Texas Historical Commission, Austin.

1998 Archaeological Test Excavations at Mission Nuestra Señora del Refugio (41RF1), U.S. 77, Refugio County, Texas. Archaeological Studies Program, Environmental Affairs Division, Texas Department of Transportation, Austin. 
Crawford, C. D.

1971 An Archeological Reconnaissance of Ecleto Creek Watershed, South Central Texas. Survey Report No. 8. Texas Archeological Salvage Project, The University of Texas at Austin.

Davis, E. M.

1968 An Informal Account of the Seventh Annual TAS Field School, June, 1968. Texas Archeology 12:2-6.

de la Teja, J. F.

1991 A Revolution Remembered: The Memoirs and Selected Correspondence of Juan N. Seguín. State House Press, Austin.

Deagan, K.

1987 Artifacts of the Spanish Colonies of Florida and the Caribbean, 1500-1800. Vol. 1. Ceramics, Glassware, and Beads. Smithsonian Institution, Washington D.C.

Driesch, A. von den

1976 A Guide to the Measurements of Animal Bones from Archaeological Sites. Peabody Museum of Archaeology and Ethnology Bulletin 1, Harvard University, Cambridge.

Dunn, W. E.

1911 Apache Relations in Texas, 1718-1750. The Quarterly of the Texas Historical Association, Volume XIV.

Espey, Huston, and Associates

1985 The Kennedy-Nixon Pipeline. Unpublished manuscript on file at the Center for Archaeological Research, The University of Texas at San Antonio.

Faulk, O.B.

1996 Presidios. In The New Handbook of Texas, R. Tyler (editor). Texas State Historical Association, Austin.

Foster, W. C.

1995 Spanish Expeditions Into Texas, 1689-1768. University of Texas Press, Austin.

Fox, A. A.

1974 An Archaeological Survey of the Nichols Creek Channel Modification, Karnes County, Texas. Archaeological Survey Report, No. 5. Center for Archaeological Research, The University of Texas at San Antonio.

1988 Archaeological Investigations at Mission Concepción, Fall of 1986. Archaeological Survey Report, No. 172. Center for Archaeological Research, The University of Texas at San Antonio.

Fox, A. A., and C. L. Tennis

1995 Use of Ceramics in Reconstructing Early San Antonio History. Paper presented to the Society of Historical Archaeology, Washington, D. C. Copy on file at the Center for Archaeological Research, The University of Texas at San Antonio.

Fox, D. E.

1979 The Lithic Artifacts of Indians at the Spanish Colonial Missions, San Antonio, Texas. Special Report 8, Center for Archaeological Research, The University of Texas at San Antonio. 
Frantz, J. B.

1976 Texas, A Bicentennial History. W. W. Norton \& Company, New York.

Frink, D. S.

1992 The Chemical Variability of Carbonized Organic Matter Through Time. Archaeology of Eastern North America 20:67-79.

1994 The Oxidizable Carbon Ration (OCR): A proposed Solution to Some of the Problems Encountered with Radiocarbon Data. North American Archaeologist 15(1):17-29.

1999 Oxidizable Carbon Ratio (OCR) Dates at 41KA26. Manuscript on file at the Center for Archaeological Research, The University of Texas at San Antonio.

Gerald, R. E.

1968 Spanish Presidios of the Late Eighteenth Century in Northern New Spain. Museum of New Mexico Research Records No. 7, Museum of New Mexico Press, Santa Fe.

General Land Office, Spanish Archives (GLO-SA), Austin

1758 "Compromise made in 1758 by Luis Menchaca to Andrés Hernandéz," April 12, Translation, Volume 42, No. 98.

Gilbert, B. M.

1973 Mammalian Osteo-archaeology: North America. Missouri Archaeological Society, Columbia.

Gilmore, K.

1973 The Keeran Site: The Probable Site of La Salle's Fort St. Louis in Texas. Office of the State Archeologist Reports, Number 24. Texas Historical Commission, Austin.

1974 Mission Rosario: Archeological Investigations 1973. Archeological Report 14, Part 1, Texas Parks and Wildlife Department, Historic Sites and Restoration Branch, Austin.

1975 Mission Rosario: Archeological Investigations 1974. Archeological Report 14, Part 2, Texas Parks and Wildlife Department, Historic Sites and Restoration Branch, Austin.

Goggin, J. M.

1968 Spanish Majolica in the New World, Types of the Sixteenth to Eighteenth Centuries. Yale Publications in Anthropology 72. Department of Anthropology, Yale University, New Haven.

Goode, M. G.

1984 Testing of Archaeological Sites 41KA26 and 41KA85, Karnes County, FM887: Bridge Replacement at Cibolo Creek. Letter report on file at the Center for Archaeological Research, The University of Texas at San Antonio.

Gould, S. J.

1966 Allometry and Size in Ontogeny and Phylogeny. Biological Review of the Cambridge Philosophical Society 41:587-640.

1971 Geometric Similarity in Allometric Growth: A Contribution to the Problem of Scaling in the Evolution of Size. The American Naturalist 105(942):113-137.

Graham, J.

1978 Folk Housing in South and West Texas: Some Comparisons. In The Proceedings: An Exploration of a Common Legacy, M. E. Heck, project director, pp. 38-45. Texas Historical Commission, Austin. 
Grayson, D. K.

1973 On the Methodology of Faunal Analysis. American Antiquity 38(4):432-439.

1979 On the Quantification of Vertebrate Archaeofauna. In Advances in Archaeological Method and Theory, Vol. 2, edited by M. B. Schiffer, pp. 199-237. Academic Press, New York.

1981 The Effects of Sample Size on Some Derived Measures in Vertebrate Faunal Analysis. Journal of Archaeological Science 8(1):77-88.

Habig, M. A.

1968 The Alamo Chain of Missions, A History of San Antonio's Five Old Missions. Franciscan Herald Press, Chicago.

Hall, D. A.

1998 Clovis Site on the Gulf Coast Yields Booty Only to Waves: Highway Project Focuses New Interest on McFadden Beach. Mammoth Trumpet 13(4):7-12.

Hall, G. D., T. R. Hester, and S. L. Black

1986 The Prehistoric Sites at Choke Canyon Reservoir, Southern Texas: Results of Phase II Archaeological Investigation. Choke Canyon Series 10. Center for Archaeological Research, The University of Texas at San Antonio.

Hard, R. J., I. W. Cox, K. J. Gross, B. A. Meissner, G. J. Méndez, C. L. Tennis, and J. E. Zapata

1995 Excavations at Mission San José y San Miguel de Aguayo, San Antonio, Texas. Archaeological Survey Report, No. 218. Center for Archaeological Research, The University of Texas at San Antonio.

Hardesty, D. L.

1975 The Niche Concept: Suggestions for Its Use in Human Ecology. Human Ecology 3(2):71-85.

Harris, R. K., and I. M. Harris

1967 Trade Beads, Projectile Points, and Knives. In A Pilot Study of Wichita Indian Archaeology and Ethnohistory, compiled by R. B. Bell, E. B. Jelks, and W. W. Newcomb). Report to the National Science Foundation, Grant GS-964.

Hazlewood, C.

1996 Kosciusko, Texas. In The New Handbook of Texas, vol. 3, edited by R. Tyler, pp. 1158, Texas State Historical Association, Austin

Hester, T. R.

1977 The Lithic Technology of Mission Indians in Texas and Northeastern Mexico. Lithic Technology 6(12):9-13.

1980a Digging into South Texas Prehistory. Corona Publishing. San Antonio.

1980b A Survey of Paleo-Indian Archaeological Remains Along the Texas Coast. In Papers on the Archaeology of The Texas Coast, edited by L. Highley and T. R. Hester, pp. 1-12. Special Report, No. 11. Center for Archaeological Research, The University of Texas at San Antonio.

1982 Prehistoric Continuities: Mission Indian Chipped Stone Tools. In Historic and Cultural Landscape Survey for the San Antonio Missions, pp. 205-210. Environmental and Cultural Services, San Antonio.

1989a Introduction. In From the Gulf to the Rio Grande: Human Adaptation in Central, South, and Lower Pecos Texas, by T. R. Hester, S. L. Black, D. G. Steele, B. W. Olive, A. A. Fox, K. J. Reinhard, and L. C. Bement, pp. 1-4. Arkansas Archeological Survey Research Series 33. Arkansas Archeological Survey. 
1989b Perspectives on the Material Culture of the Mission Indians of the Texas-Northeastern Mexico Borderlands. In Columbian Consequences, Volume 1: Archaeological and Historical Perspectives on the Spanish Borderlands West, edited by D. H. Thomas, pp. 213-229. Smithsonian Institution Press, Washington, D.C.

1995 The Prehistory of South Texas. Bulletin of the Texas Archaeological Society 66:427-459.

Hester, T. R., and R. C. Parker

1970 The Berclair Site: A Late Prehistoric Component in Goliad County, Southern Texas. Bulletin of the Texas Archeological Society 41:1-23.

Hester, T. R., and T. L. Walter (editors)

1998 Archeology in Victoria County, Texas: Manual for the 1998 Texas Archeological Society Field School. Texas Archeological Society, Austin.

Hester, T. R., S. L. Black, D. G. Steele, B. W. Olive, A. A. Fox, K. J. Reinhard, and L. C. Bement, (editors)

1989 From the Gulf to the Rio Grande: Human Adaptation in Central, South, and Lower Pecos Texas. Arkansas Archeological Survey Research Series 33. Arkansas Archeological Survey.

Hindes, V. K., A. A. Fox, and E. H. Schmiedlin

1999 An Overview of Test Excavations and Documentary Research at 41VT10, the Tonkawa Bank Site, Victoria City Park, Victoria, Texas. Bulletin of the Texas Archeological Society 70:79-96.

Hoese, H. D., and R. H. Moore

1977 Fishes of the Gulf of Mexico, Texas, Louisiana, and Adjacent Waters. Texas A\&M University Press, College Station.

Huebner, J. A., R. Blackburn, C. K. Chandler, J. L. Mitchell, and E. H. Schmiedlin

1996 Human Burial Recovery from 41KA89, Karnes County, Texas. La Tierra 23(1):16-20.

Humboldt, A. de

1941 Ensayo Politico Sobre al Reino de la Nueva Espana, 4 volumes, edited and annotated by V. A. Robles. Editorial Pedra Robredo, Mexico.

Hunziker, J. M., and A. A. Fox

1998 Archaeological Testing at Goliad State Park, Goliad County, Texas. Archaeological Survey Report, No. 260. Center for Archaeological Research, The University of Texas at San Antonio.

Ivey, J. E., and A. A. Fox

1999 Archaeological Investigations at Mission Concepción and Mission Parkway. Archaeological Survey Report, No. 114. Center for Archaeological Research, The University of Texas at San Antonio.

Jackson, J.

1986 Los Mesteños: Spanish Ranching in Texas, 1721-1821. Texas A\&M University Press, College Station.

Jones, C. J., and A. A. Fox

1983 Archaeological Testing at Rancho de las Cabras, Wilson County, Texas. Third Season. Archaeological Survey Report, No. 123. Center for Archaeological Research, The University of Texas at San Antonio. 
Kelly, T. C., and L. Highley

1979 The Jackpump Project, An Archaeological Survey of Portions of Karnes and Gonzales Counties, Texas. Archaeological Survey Report, No. 65. Center for Archaeological Research, The University of Texas at San Antonio.

Kelly, T. C., and E. Roemer

1976 The Panna Marie Project: An Archaeological Survey of the Region Between the San Antonio River and Cibolo Creek, Karnes County, Texas. On file, Center for Archaeological Research, The University of Texas at San Antonio.

Kelly, T. C., E. Roemer, and S. Black

1977 Panna Maria II: Additional Archaeological Survey in Karnes County, Texas. On file, Center for Archaeological Research, The University of Texas at San Antonio.

Kotter, S. M., and J. A. Guy

1980 Archeological Survey and Assessment of Two Areas to be Affected by Proposed Critical Area Treatment Measures Within the Ecleto Creek Watershed, Karnes County, Texas. Reports of Investigations No. 5. Prewitt and Associates, Austin.

Larsen, E. B.

1975 American Historical Views on Staffordshire China. Dover Publications, New York.

Lister, F. C., and R. H. Lister

1974 Majolica in Colonial Spanish America. Historical Archaeology 8:17-52.

Logan, H. C.

1959 Cartridges - a pictorial digest of small arms ammunition. Bonanza Books, New York.

Lynn, W. M., D. E. Fox, and N. O’Malley

1977 Cultural Resource Survey of Choke Canyon Reservoir, Live Oak and McMullen Counties, Texas. Archeological Survey Report 20. Office of the State Archeologists, Texas Historical Commission, Austin.

McBee, K., and R. J. Baker

1982 Dasypus novemcinctus. Mammalian Species Account No. 162, American Society of Mammalogists.

McGraw, A. J.

1979 An Archaeological and Historical Survey of the Hasse, Moy, and Wiatrek Properties of the Conquista Project, Karnes County, Texas. Archaeological Survey Report, No. 81. Center for Archaeological Research, The University of Texas at San Antonio.

McKinney, W. W.

1981 Early Holocene Adaptations in Central and Southern Texas: The Problem of the Paleo-Indian-Archaic Transition. Bulletin of the Texas Archaeology Society 52:91-120. 
Meissner, B. A.

1997 Making the Man: Clothing Remains from the Alamodome Project. In Archaeology of the Alamodome: Investigations of a San Antonio Neighborhood in Transition. Vol. III, Artifacts and Special Studies, edited by A. A. Fox, M. Renner, and R. J. Hard, pp. 119-164. Archaeological Survey Report, No. 238. Center for Archaeological Research, The University of Texas at San Antonio.

Mitchell, J. L., C. K. Chandler, and T. C. Kelly

1984 The Rudy Haiduk Site (41 KA 23): A Late Archaic Burial in Karnes County, Texas. La Tierra 11(2):12-29.

Morfi, Fray J. A.

1935 History of Texas: 1673-1779, Volume II. Carlos Eduardo Castañeda, translator, Quivira Society, Albuquerque.

Mottashed Cole, N., J. Warren, M. Bircket, and E. Griffin

1994 Final Report of Testing 41KA14 and 41KA15 in the Ecleto Creek Watershed, Karnes County, Texas. Soil Conservation Service, Temple, Texas.

Mounger, M. A.

1959 Mission Espíritu Santo of Coastal Texas: An Example of Historic Site Archeology. Unpublished Master's thesis, copy on file at the Center for Archaeological Research, The University of Texas at San Antonio.

Munsey, C.

1970 The Illustrated Guide to Collecting Bottles. Hawthorne Books, New York.

Natural Fibers Information Center

1987 The Climates of Texas. Bureau of Business Research, Graduate School of Research. The University of Texas at Austin.

Neff, H., and M. D. Glascock

2000 Instrumental Neutron Activation Analysis of Spanish Colonial Ceramics from Southern Texas (41ZP79). Research Reactor Center, University of Missouri, Columbia.

Nesmith, S.

1992 Military Artifacts. In Archaeological Investigations in Alamo Plaza, San Antonio, Texas, 1988: and 1989 by A. A. Fox, pp. 56-62. Archaeological Survey Report, No. 205. Center for Archaeological Research, The University of Texas at San Antonio.

Nickels, D. L.

1999 Researcher Reports Progress to TAS Donors Fund. Texas Archeology 43(4):7. Newsletter of the Texas Archeological Society, San Antonio.

20001999 Excavations at Mission Rosario, Goliad County, Texas. Archaeological Survey Report, No. 298. Center for Archaeological Research, The University of Texas at San Antonio.

Nightengale, B. A., and L. C. Bement

1982 A Cultural Resource Survey and Assessment of the Texaco-Sunedco Hobson Uranium Prospect, Karnes County, Texas. Technical Bulletin 51. Texas Archeological Survey, The University of Texas at Austin. 
Nowak, R. M.

1991 Walker's Mammals of the World. The Johns Hopkins University Press, Baltimore.

O'Connor, K. S.

1966 The Presidio le Bahia del Espritu Santo de Zuniga, 1721-1846. Von Boeckmann-Jones Co., Austin.

Owens, J. M.

1982 Radiographic Interpretation for the Small Animal Clinician. Ralston Purina Company, St. Louis.

Parry, W. J., and R. L. Kelly

1987 Expedient Core Technology and Sedentism. In The Organization of Core Technology, edited by J. Johnson and C. Morrow, pp. 285-304. Westview Press, Boulder.

Perkins, D., Jr., and P. Daly

1968 A Hunter's Village in Neolithic Turkey. Scientific American 219(5):96-106.

Perttula, T. K.

Analysis of the Native American Ceramics from Nuestra Senora de Refugio Mission (41RF1). Manuscript on file with the author. Forthcoming.

Perttula, T. K., J. B. Boyd, S. A. Iruegas, and B. Nelson

1999 Archeological Investigations at Area I, the Cabaseno Ranch (41ZP79), Falcon Reservoir. Bulletin of the Texas Archeological Society 70:327-338.

Peterson, H. L.

1958 American Knives. Charles Scribner's Sons, New York.

Pielou, E. C.

1966 Species-Diversity and Pattern-Diversity in the Study of Ecological Succession. Journal of Theoretical Biology 10:370-383.

Pollan, S. D., W. S. Gross, A. C. Earls, J. T. Pollan, Jr., and J. L. Smith

1996 Nineteenth-Century Transfer-Printed Ceramics from the Townsite of Old Velasco (41BO125), Brazoria County, Texas: An Illustrated Catalogue. Prewitt and Associates, Austin.

Purdue, J. R.

1983 Epiphyseal Closure in White-Tailed Deer. Journal of Wildlife Management 47(4):1207-1213.

Reitz, E. J., and D. Cordier

1983 Use of Allometry in Zooarchaeological Analysis. In Animals in Archaeology: 2. Shell Middens, Fishes, and Birds, edited by C. Grigson and J. Clutton-Brock, pp. 237-252. BAR International Series 183, Oxford.

Reitz, E. J., and E. S. Wing

1999 Zooarchaeology. Cambridge University Press, New York. 
Reitz, E. J., I. R. Quitmyer, H. S. Hale, S. J. Scudder, and E. S. Wing

1987 Application of Allometry to Zooarchaeology. American Antiquity 52(2):304-317.

Reitz, E. J., and M. A. Zierden

1991 Cattle Bones and Status from Charleston, South Carolina. In: Beamers, Bobwhites, and Blue-points: Tributes to the Career of Paul W. Parmalee, edited by J. R. Purdue, W. E. Klippel, and B. W. Styles, pp. 395-407. Illinois State Museum, Springfield.

Rice, P. M.

1996 Recent Ceramic Analysis: 1. Function, Style, and Origins. Journal of Archaeological Research 4(2):133-163.

Rick, A.

1975 Bird Medullary Bone: A Seasonal Dating Technique for Faunal Analysis. Canadian Archaeological Association Bulletin 7:183-190.

Ricklis, R. A.

1994 Toyah Components: Evidence for Occupation in the Project Area During the Latter Part of the Late Prehistoric Period. In Archaic and Late Prehistoric Human Ecology in the Middle Onion Creek Valley, Hays County, Texas, by R. A. Ricklis and M. B. Collins, pp. 207-316. 2 Vols. Studies in Archeology 19. Texas Archeological Research Laboratory, The University of Texas at Austin.

1995a Prehistoric Occupation of the Central and Lower Texas Coast: A Regional Overview. Bulletin of the Texas Archeological Society 66:266-300.

1995b The Ceramics of the Toyah Horizon and the Rockport Phase as Indicators of Some Basic Sociocultural Patterns. Bulletin of the Texas Archeological Society 66:195-203.

1996 The Karankawa Indians of Texas: An Ecological Study of Cultural Tradition and Change. University of Texas Press, Austin.

1998 Archaeological Investigations at the Spanish Colonial Mission Sites of Espíritu Santo and Nuestra Señora del Rosario, Goliad County, Texas: Interim Report on the 1997 Testing. Coastal Archaeological Studies, Corpus Christi, Texas.

1999a The Spanish Colonial Missions of Espiritu Santo (41GD1) and Nuestra Senora del Rosario (41GD2), Goliad, Texas: Exploring Patterns of Ethnicity, Interaction, and Acculturation. Bulletin of the Texas Archeological Society 70:133-168.

1999b Testing at Villa de La Bahia. Current Archeology in Texas 1(1):14-17. Texas Historical Commission, Austin.

Roell, C. H.

1996a Nuestra Señora del Espíritu Santo de Zúñiga Mission. In The New Handbook of Texas, vol. 4, edited by R. Tyler, pp. 1062-1064, Texas State Historical Association, Austin

1996b Carlos Rancho, Texas. In The New Handbook of Texas, vol. 1, edited by R. Tyler, pp. 977-978, Texas State Historical Association, Austin

Roemer, E.

1980 An Archaeological Survey for the Conquista Project of Nieschwietz-Bodden Properties, Karnes County, Texas. Archaeological Survey Report, No. 92. Center for Archaeological Research, The University of Texas at San Antonio.

Russell, C. P.

1957 Guns on the Early Frontier. University of California Press, Berkeley. 
Schiffer, M. B., J. M. Skibo, T. C. Boelke, M. A. Neupert, and M. Aronson

1994 New Perspectives on Experimental Archaeology: Surface Treatments and Thermal Response of the Clay Cooking Pot. American Antiquity 59(2):197-217.

Schmid, E.

1972 Atlas of Animal Bones for Prehistorians, Archaeologists, and Quaternary Geologists. Elsevier, Amsterdam.

Schmiedlin, E. H.

1993 Investigation of a Toyah Horizon Site in Karnes County, Texas. The Cache 1:33-45. Office of the State Archeologist, Texas Historical Commission, Austin.

Schroeder, E. A., J. T. Jones, and K. Taylor

1997 Intensive Archeological Survey of the Falls City Commercial Aquaculture Facility, Karnes County, Texas. PPA Cultural Resources Report Number 9. Paul Price Associates, Austin.

Schuetz, M. K.

1969 The History and Archeology of Mission San Juan Capistrano, San Antonio, Texas (Vol. 2). Description of the Artifacts and Ethnohistory of the Coahuiltecan Indians. State Building Commission, Archeology Program Report 11. Austin.

1970 Excavation of a Section of the Acequia Madre in Bexar County, Texas, and Archeological Investigations at Mission San José in April 1968. Archeological Report 19. Texas Historical Survey Committee, Austin.

1980 The Indians of the San Antonio Missions 1718-1821. Ph.D. dissertation, Department of Anthropology, University of Texas at Austin.

Scurlock, D.

1972 Copy of original site form for 41KA26. Manuscript on file. Center for Archaeological Research, The University of Texas at San Antonio.

Sellari, C., and D. Sellari

1975 The Illustrated Price Guide to Antique Bottles. Country Beautiful, Waukasha, Wisconsin.

Severinghaus, C. W.

1949 Tooth Development and Wear as Criteria of Age in White-Tailed Deer. Journal of Wildlife Management 13(2):195-216.

Shafer, H. J., and C. L. Bond

1985 An Archeological Review of the Central Texas Coast. Bulletin of the Texas Archeological Society 54:271-285.

Shannon, C. E., and W. Weaver

1949 The Mathematical Theory of Communication. University of Illinois Press, Urbana.

Sheldon, A. L.

1969 Equitability Indices: Dependence On the Species Count. Ecology 50:466-467. 
Shipman, P., and J. Rose

1983 Evidence of Butchery and Hominid Activities at Torralba and Ambrona: An Evaluation Using Microscopic Techniques. Journal of Archaeological Science 10(5):465-474.

Simmons, M., and F. Turley

1980 Southwestern Colonial Ironworks. Museum of New Mexico Press, Santa Fe.

Simpson, G. G.

1941 Large Pleistocene Felines of North America. American Museum Novitates 1136:1-27.

Simpson, G. G., A. Roe, and R. C. Lewontin

1960 Quantitative Zoology. Harcourt, Brace, and Co., New York.

Skibo, J. M.

1992 Pottery Function: A Use-Alteration Perspective. Plenum Press, New York.

Smith, H. P., Jr.

1978 Archaeological Survey and Assessment of Properties for the Conquista Project in Live oak and Karnes Counties, Texas. Archaeological Survey Report, No. 64. Center for Archaeological Research, The University of Texas at San Antonio.

Snyder, J. B., and L. Bockol

1995 Historical Staffordshire: American Patriots and Views. Schiffer, Atglen, Pennsylvania.

Story, D. A.

1985 Adaptive Strategies of Archaic Cultures of the West Gulf Coast Plain. In Prehistoric Food Production in North America, edited by R. I. Ford, pp. 19-56. Anthropological Papers 75, Museum of Anthropology, University of Michigan, Ann Arbor.

Suhm, D. A.

1955 Excavations at the Collins Site, Travis County, Texas. Bulletin of the Texas Archeological Society 26:7-54.

Suhm, D. A., and E. B. Jelks

1962 Handbook of Texas Archeology: Type Descriptions. Texas Archeological Society Special Publication I and Texas Memorial Museum Bulletin 4. Austin.

Suhm, R. W.

1980 The La Paloma Mammoth Site, Kenedy County, Texas. In Papers on the Archaeology of the Texas Coast, edited by L. Highley and T. R. Hester, pp. 79-103. Special Report 11. Center for Archaeological Research, The University of Texas at San Antonio.

Sullivan, A. P. III, and K. C. Rozen

1985 Debitage Analysis and Archaeological Interpretation. American Antiquity 50(4):755-779. 
Taylor, A. J., and A. A. Fox

1985 Archaeological Survey and Testing at Rancho de las Cabras, 41WN30, Wilson County, Texas, Fifth Season. Archaeological Survey Report, No. 144. Center for Archaeological Research, The University of Texas at San Antonio.

Taylor, A. J., and C. L. Highley

1995 Archeological Investigations at The Loma Sandia Site (41LK28), A Prehistoric Cemetery and Campsite in Live Oak County, Texas, Vols. 1 and 2. Studies in Archeology 20. Texas Archeological Research Laboratory, The University of Texas at Austin.

Teltser, P. A.

1993 An Analytic Strategy for Studying Assemblage-Scale Ceramic Variation: A Case Study from Southeast Missouri. American Antiquity 58(3):530-543.

Temple, L. A.

1996 Panna Maria, Texas. In The New Handbook of Texas, vol. 5, edited by R. Tyler, pp. 44-45, Texas State Historical Association, Austin.

Tennis, C. L.

2001 Mission Nuestra Señora del Refugio. Center for Archaeological Research, The University of Texas at San Antonio. Forthcoming.

Thomas, D. H.

1971 On Distinguishing Natural From Cultural Bone in Archaeological Sites. American Antiquity 36(3):366-371.

Thonhoff, R. H.

1964 The First Ranch in Texas. Southwest Texas Heritage Series, No. 1, Old Helena Foundation, Karnes City, Texas.

1970 "El Fuerte Del Santa Cruz" A Study in Historical Site Identification, unpublished manuscript, August.

1992 El Fuerte Del Cibolo: Sentinel of the Béxar-La Bahia Ranches. Eakin, Austin, Texas.

1996a Fuerte de Santa Cruz del Cíbolo. In The New Handbook of Texas, vol. 3, edited by R. Tyler, pp. 23, Texas State Historical Association, Austin.

1996b Cestohowa, Texas. In The New Handbook of Texas, vol. 2, edited by R. Tyler, pp. 22-23, Texas State Historical Association, Austin.

Tomka, S. A.

1989 Differentiating Lithic Reduction Techniques: An Experimental Approach. In Experiments in Lithic Technology, edited by D. S. Amick and R. P. Mauldin, pp. 137-161. BAR International Series 528. British Archaeological Reports, Oxford.

1999 Historic Period Lithic Technology at Mission San José y San Miguel de Aguayo. Bulletin of the Texas Archeological Society 70:241-264.

Tomka, S. A., and A. A. Fox

1999 Mission San José Indian Quarters Wall Base project. Bexar County, Texas. Archaeological Survey Report, No. 278. Center for Archaeological Research, The University of Texas at San Antonio. 
Tomka, S. A., T. K. Perttula, and R. J. Hard

1999 Archaeology of the Rio Grande and Central Coastal Plains, Texas: A Planning Document. 2 vols. Archaeological Survey Report, No. 266. Center for Archaeological Research, The University of Texas at San Antonio.

Toulouse, J. H.

1971 Bottle Makers and Their Marks. Thomas Nelson, New York.

Tucker, G. C., Jr., and J. E. Warren

1992 Archaeological Site 41KA95: Results of Evaluative Testing for the Falls City Uranium Mill Tailings Remedial Action Project, Karnes County, Texas. Powers Elevation Company, Aurora, Colorado (privately published). Abstract on file at the Center for Archaeological Research, The University of Texas at San Antonio.

Tunnell, C. D.

1966 A Description of Enameled Earthenware from an Archeological Excavation at Mission San Antonio de Valero (the Alamo). State Building Commission, Archeological Program Report 2. Austin.

Turner, E. S., and T. R. Hester

1993 A Field Guide to Stone Artifacts of Texas Indians. Second Edition. Gulf Publishing, Houston.

Uecker, H. G., and C. McKenzie

1991 Falls City Uranium Mill Tailings Remedial Action Project. Site forms on file at the Center for Archaeological Research, The University of Texas at San Antonio.

Wakefield, W. W.

1968 Archeological Survey of Palmento Bend and Choke Canyon Reservoir, Texas. Survey Report 5. Texas Archeological Survey, The University of Texas at Austin.

Walter, T. L.

1997 The Dynamics of Culture Change and Its Reflection in the Archeological Record at Espiritu Santo de Zuñiga, Victoria County, Texas. Special Publications 7. Southern Texas Archaeological Association and Studies in Archeology 23. Texas Archeological Research Laboratory, The University of Texas at Austin.

1999 A Preliminary Report of the 1997 TAS Field School Excavations in Area A at Mission Espiritu Santo de Zuniga (41VT11), Victoria County, Texas. Bulletin of the Texas Archeological Society 70:97-122.

Watson, J. P. N.

1978 The Interpretation of Epiphyseal Fusion Data. In Research Problems in Zooarchaeology, edited by D. R. Brothwell, J. D. Thomas, and J. Clutton-Brock, pp. 97-102. University of London Institute of Archaeology, Occasional Publications 3.

Webber, J. J.

1999 Five Dead Cats at Stobo Plantation. Paper presented at the 56th Annual Meeting of the Southeastern Archaeological Conference, Pensacola.

Weddle, R. S.

1968 San Juan Bautista, Gateway to Spanish Texas. University of Texas Press, Austin. 
Weinstein, R. A.

1991 Lido Harbor (41GV82): A Late Prehistoric Campsite and Extraction Locale, Galveston County, Texas. Submitted to the United States Army Corps of Engineers, Galveston District. Copies available from Coastal Environments, Inc, Baton Rouge, Louisiana.

White, T. E.

1953 A Method of Calculating the Dietary Percentages of Various Food Animals Utilized by Aboriginal Peoples. American Antiquity 19(2):396-398.

Wing, E. S., and A. B. Brown

1979 Paleonutrition: Method and Theory in Prehistoric Foodways. Academic Press, New York.

Wormser, A. J., and A. J. McGraw

1988 Results of Testing at Site 41KA87, Karnes County, Texas. State Department of Highways and Public Transportation, Highway Design Division. Manuscript on file at the Center for Archaeological Research, The University of Texas at San Antonio. 



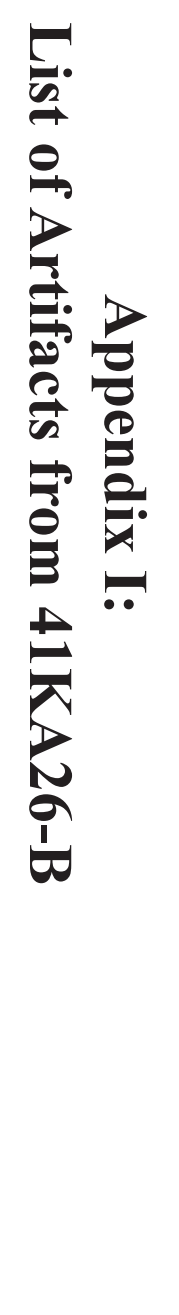


Appendix I: List of Artifacts from 41KA26-B

\section{KA26-B}

ฉ

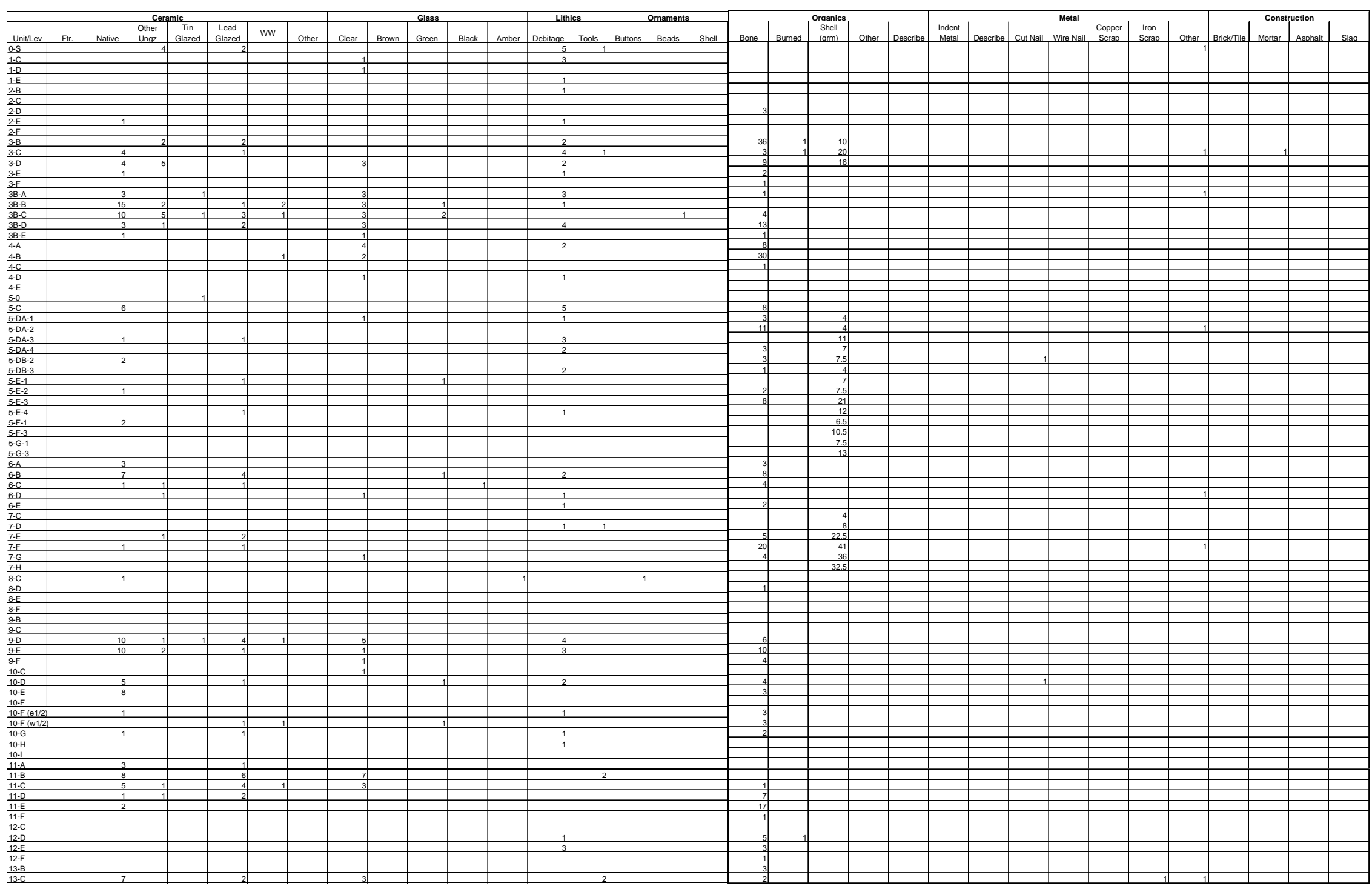


Appendix I continued...

\section{KA26-B}

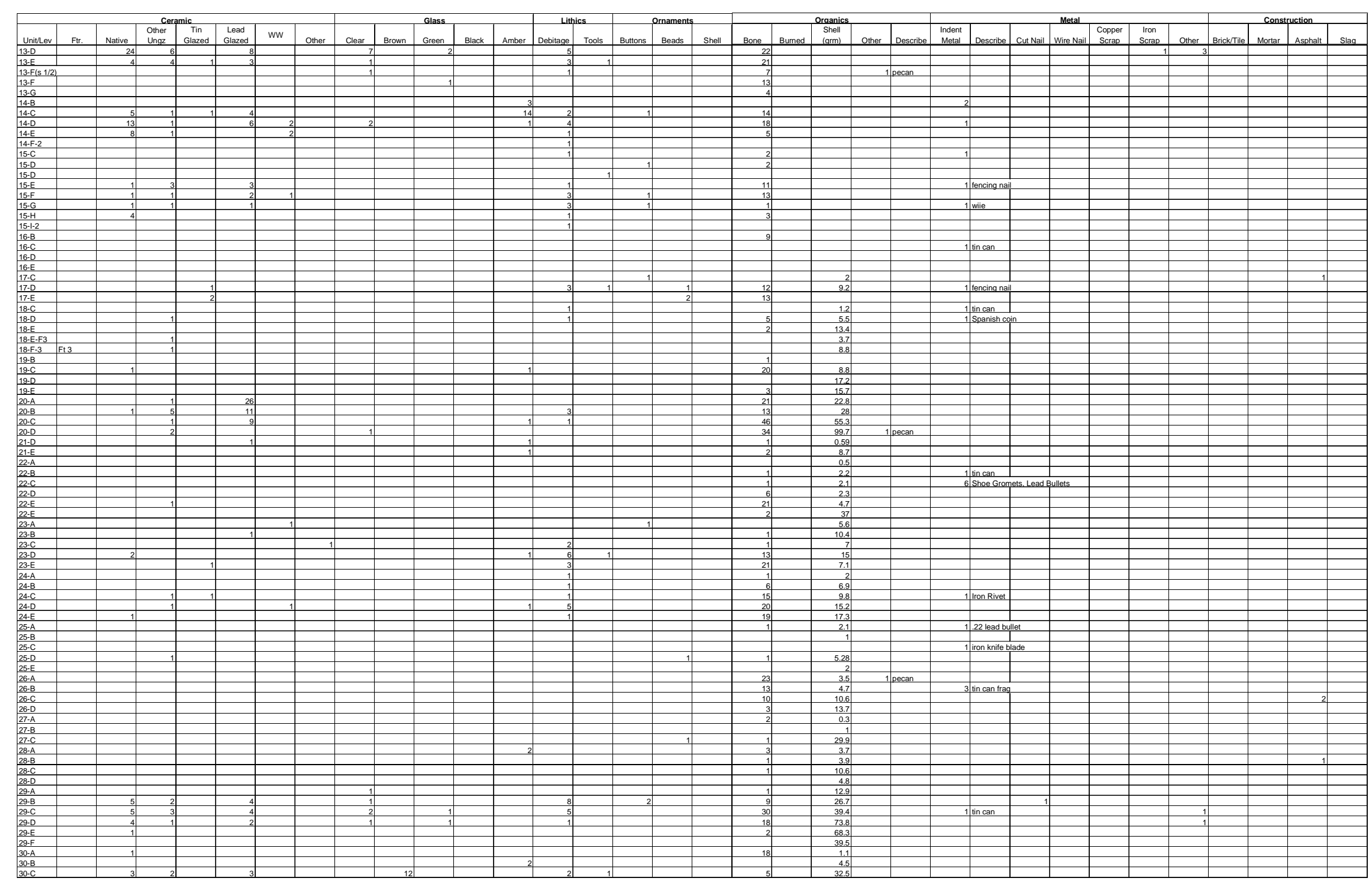


Appendix I continued...

\section{KA26-B}

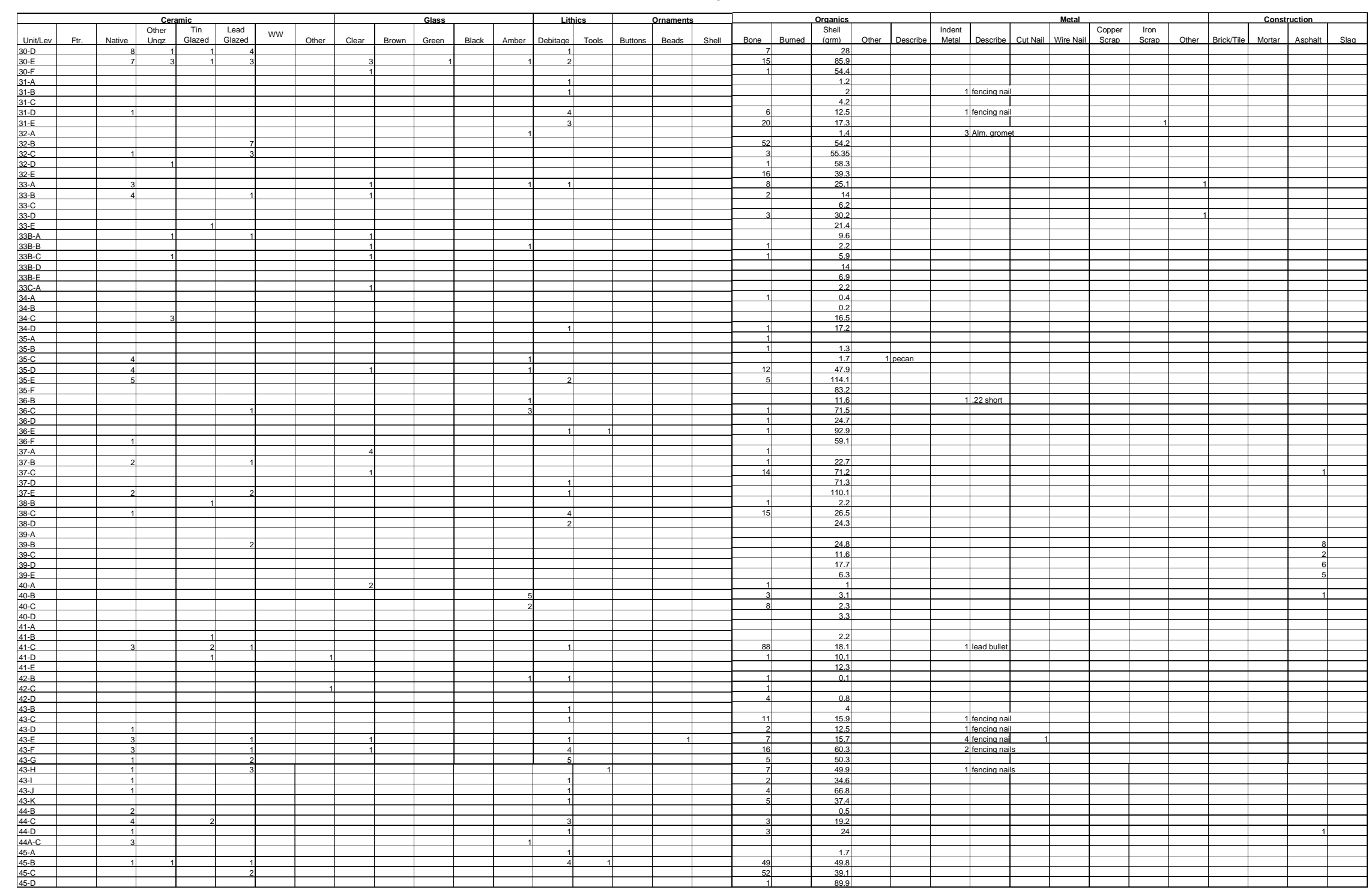


Appendix I continued...

41KA26-B

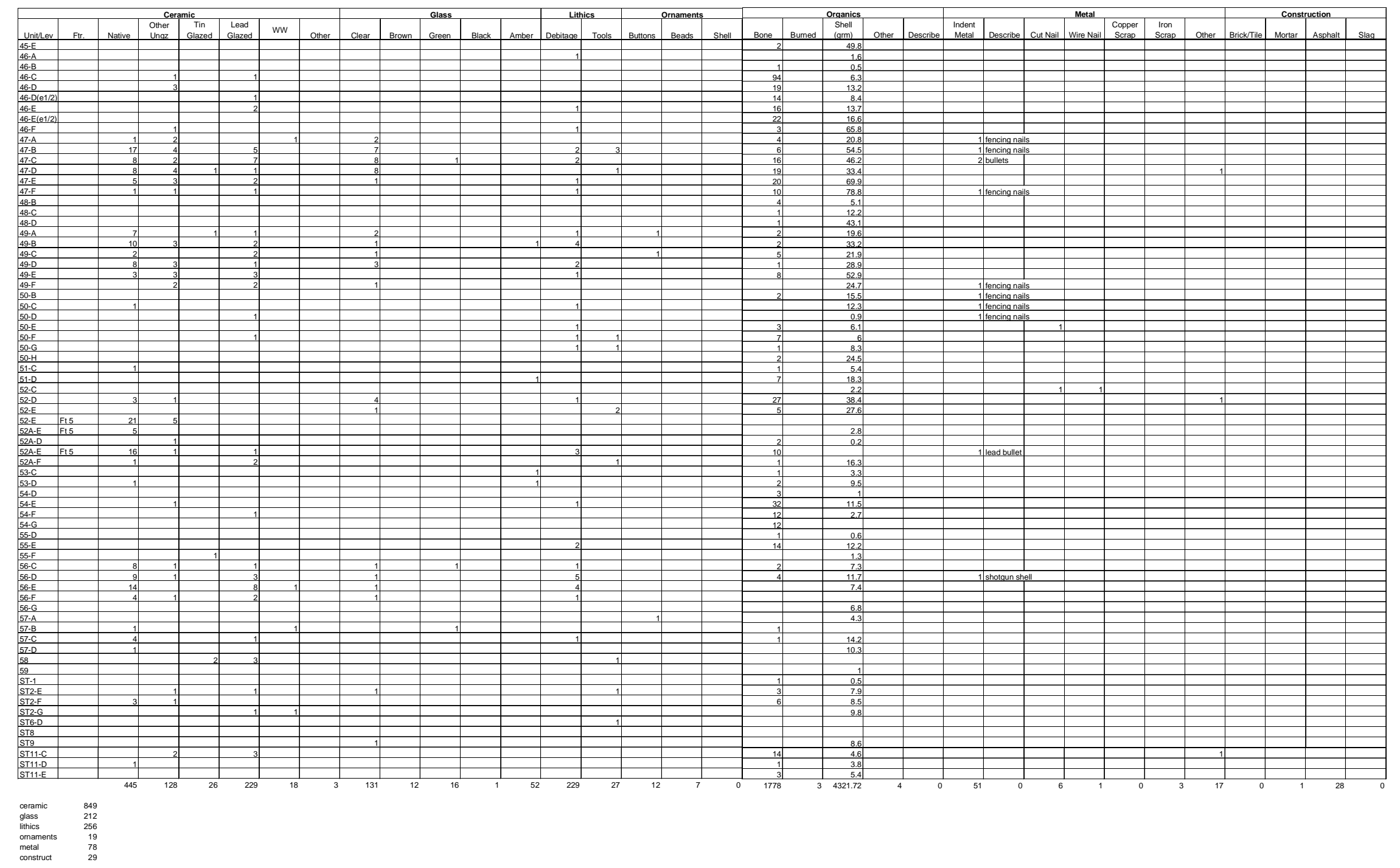





\section{Appendix II: \\ 41KA26-B Paste and Temper Identification}


Appendix II: 41KA26-B Paste and Temper Identification

\begin{tabular}{|l|c|c|c|c|c|c|}
\hline Provenience & $\begin{array}{c}\text { Not } \\
\text { Analyzed } \\
(>1 \mathrm{~cm})\end{array}$ & Bs & Bm & Bp & Sp & N \\
\hline 3 B-A & & 2 & & & 1 & 3 \\
\hline 6-A & & 2 & 1 & & & 3 \\
\hline $11-\mathrm{A}$ & & 2 & 1 & & & 3 \\
\hline $30-\mathrm{A}$ & 1 & & & & & 1 \\
\hline $33-\mathrm{A}$ & 2 & 1 & & & & 3 \\
\hline $47-\mathrm{A}$ & 1 & & & & & 1 \\
\hline 49-A & 3 & 1 & & 3 & & 7 \\
\hline Subtotal-A & 7 & 8 & 2 & 3 & 1 & 21 \\
\hline
\end{tabular}

\begin{tabular}{|l|c|c|c|c|c|c|}
\hline 3B-B & 7 & 4 & 3 & 1 & & 15 \\
\hline 5DB-2 & 1 & & & & 1 & 2 \\
\hline 6-B & 3 & 3 & & & 1 & 7 \\
\hline $11-\mathrm{B}$ & 2 & 2 & 4 & & & 8 \\
\hline 20-B & & & & & 1 & 1 \\
\hline 29-B & 1 & 3 & 1 & & & 5 \\
\hline $33-\mathrm{B}$ & 1 & 1 & 1 & 2 & & 4 \\
\hline $37-\mathrm{B}$ & 1 & & & $1 / 1$ & & 2 \\
\hline $44-\mathrm{B}$ & 3 & 2 & 7 & 3 & $2 / 1$ & 17 \\
\hline $45-\mathrm{B}$ & 1 & 1 & 3 & & $5 / 1$ & 10 \\
\hline $47-\mathrm{B}$ & 21 & 17 & 19 & $8 / 1$ & $11 / 2$ & 76 \\
\hline $49-\mathrm{B}$ & & 1 & & & & 1 \\
\hline $57-\mathrm{B}$ & & & & & & 1 \\
\hline 0.05 & & & & & & 1 \\
\hline Subtotal-B & 1 & & & & & \\
\hline
\end{tabular}


Appendix II, continued...

\begin{tabular}{|c|c|c|c|c|c|c|}
\hline Provenience & $\begin{array}{c}\text { Not } \\
\text { Analyzed } \\
(>1 \mathrm{~cm}) \\
\end{array}$ & Bs & $\mathrm{Bm}$ & $\mathrm{Bp}$ & $\mathrm{Sp}$ & $\mathrm{N}$ \\
\hline $3-\mathrm{C}$ & 3 & 1 & & & & 4 \\
\hline 3B-C & 2 & 2 & 5 & 1 & & 10 \\
\hline $5-\mathrm{C}$ & 3 & & & & 3 & 6 \\
\hline 6-C & & & 1 & & & 1 \\
\hline $11-\mathrm{C}$ & 1 & 3 & & 1 & & 5 \\
\hline $13-\mathrm{C}$ & 2 & 4 & 1 & & & 7 \\
\hline $14-\mathrm{C}$ & 3 & 1 & 1 & & & 5 \\
\hline $19-\mathrm{C}$ & 1 & & & & & 1 \\
\hline $29-\mathrm{C}$ & 2 & 1 & & 1 & 1 & 5 \\
\hline $30-\mathrm{C}$ & 1 & 1 & & & 1 & 3 \\
\hline $32-\mathrm{C}$ & 1 & & & & & 1 \\
\hline $35-\mathrm{C}$ & & 3 & 1 & & & 4 \\
\hline $38-\mathrm{C}$ & & & 1 & & & 1 \\
\hline $41-\mathrm{C}$ & 1 & 2 & & & & 3 \\
\hline $44-\mathrm{C}$ & 1 & 2 & 1 & & & 4 \\
\hline $44 \mathrm{~A}-\mathrm{C}$ & 1 & 2 & & & & 3 \\
\hline $47-\mathrm{C}$ & 2 & 2 & 3 & 1 & & 8 \\
\hline 49-C & & & 2 & & & 2 \\
\hline $50-\mathrm{C}$ & & & & 1 & & 1 \\
\hline $51-\mathrm{C}$ & & & & 1 & & 1 \\
\hline $56-\mathrm{C}$ & 2 & & 4 & 1 & 1 & 8 \\
\hline $57-\mathrm{C}$ & & & 2 & 2 & & 4 \\
\hline 5-DA-3 & & & & & 1 & 1 \\
\hline $8-\mathrm{C}$ & & & & 1 & & 1 \\
\hline Subtotal-C & 26 & 24 & 22 & 10 & 7 & 89 \\
\hline
\end{tabular}


Appendix II, continued...

\begin{tabular}{|c|c|c|c|c|c|c|}
\hline Provenience & $\begin{array}{c}\text { Not } \\
\text { Analyzed } \\
(>1 \mathrm{~cm}) \\
\end{array}$ & Bs & $\mathrm{Bm}$ & $\mathrm{Bp}$ & $\mathrm{Sp}$ & $\mathrm{N}$ \\
\hline 3-D & 3 & 1 & & & & 4 \\
\hline 3B-D & 2 & & 1 & & & 3 \\
\hline 9-D & 1 & & 2 & & 7 & 10 \\
\hline 10-D & 2 & 2 & & & $1 / 1$ & 5 \\
\hline 11-D & 1 & & & & & 1 \\
\hline $13-D$ & 3 & $7 / 1$ & 9 & 2 & 3 & 24 \\
\hline 14-D & 3 & 1 & 3 & 1 & $5 / 1$ & 13 \\
\hline 23-D & 1 & & & & 1 & 2 \\
\hline 29-D & 1 & & 2 & 1 & & 4 \\
\hline $30-\mathrm{D}$ & 3 & 2 & 3 & & & 8 \\
\hline 31-D & & 1 & & & & 1 \\
\hline $35-\mathrm{D}$ & 2 & & 1 & 1 & & 4 \\
\hline 43-D & 1 & & & & & 1 \\
\hline 44-D & 1 & & & & & 1 \\
\hline 47-D & 5 & 2 & & 1 & & 8 \\
\hline 49-D & 2 & 3 & 2 & 1 & & 8 \\
\hline 52-D & 2 & & & 1 & & 3 \\
\hline 53-D & & 1 & & & & 1 \\
\hline 56-D & 1 & 4 & 1 & & 3 & 9 \\
\hline 57-D & & 1 & & & & 1 \\
\hline ST11-D & & & 1 & & & 1 \\
\hline Subtotal-D & 34 & $25 / 1$ & 25 & 8 & $20 / 2$ & 112 \\
\hline
\end{tabular}


Appendix II, continued...

\begin{tabular}{|c|c|c|c|c|c|c|}
\hline Provenience & $\begin{array}{c}\text { Not } \\
\text { Analyzed } \\
(>1 \mathrm{~cm}) \\
\end{array}$ & Bs & $\mathrm{Bm}$ & $\mathrm{Bp}$ & $\mathrm{Sp}$ & $\mathrm{N}$ \\
\hline 2-E & 1 & & & & & 1 \\
\hline $3-E$ & & & 1 & & & 1 \\
\hline 3B-E & & & 1 & & & 1 \\
\hline 30-E & 5 & & 1 & & 1 & 7 \\
\hline 9-E & 2 & 5 & 1 & 1 & $1 / 1$ & 10 \\
\hline $10-\mathrm{E}$ & 2 & 1 & 1 & & $4 / 1$ & 8 \\
\hline $13-\mathrm{E}$ & & 2 & 1 & & 1 & 4 \\
\hline $14-\mathrm{E}$ & 5 & & 3 & & & 8 \\
\hline $15-\mathrm{E}$ & & 1 & & & & 1 \\
\hline 24-E & & & & & 1 & 1 \\
\hline 29-E & & 1 & & & & 1 \\
\hline $35-\mathrm{E}$ & 1 & 2 & 1 & 1 & & 5 \\
\hline $37-E$ & 1 & & 1 & & & 2 \\
\hline $43-\mathrm{E}$ & & & 1 & & $2 / 1$ & 3 \\
\hline $47-\mathrm{E}$ & & & 4 & 1 & & 5 \\
\hline 49-E & 1 & 1 & 1 & & & 3 \\
\hline $52-\mathrm{E}$ & & 1 & & 19 & $1 / 1$ & 20 \\
\hline 52-E, Fea. 5 & 3 & & & 1 & & 4 \\
\hline $52 \mathrm{~A}-\mathrm{E}$ & 9 & & & 7 & & 16 \\
\hline $56-\mathrm{E}$ & 4 & 2 & 5 & 1 & $2 / 1$ & 14 \\
\hline $11-5$ & 1 & & & & $1 / 1$ & 2 \\
\hline Subtotal-E & 36 & 16 & 22 & 31 & $14 / 6$ & 119 \\
\hline
\end{tabular}


Appendix II, continued...

\begin{tabular}{|l|c|c|c|c|c|c|}
\hline Provenience & $\begin{array}{c}\text { Not } \\
\text { Analyzed } \\
(>1 \mathrm{~cm})\end{array}$ & Bs & Bm & Bp & Sp & N \\
\hline $5-\mathrm{F} 1$ & & 2 & & & & 2 \\
\hline $7-\mathrm{F}$ & & & & & 1 & 1 \\
\hline $10-\mathrm{F}$ & & & & & $1 / 1$ & 1 \\
\hline $15-\mathrm{F}$ & & & 1 & & & 1 \\
\hline $36-\mathrm{F}$ & & & 1 & & & 1 \\
\hline $43-\mathrm{F}$ & & 1 & & 2 & & 3 \\
\hline $47-\mathrm{F}$ & 1 & & 1 & 1 & 1 & 4 \\
\hline $52 \mathrm{~A}-\mathrm{F}$ & 1 & 1 & & & 1 & 3 \\
\hline $56-\mathrm{F}$ & 2 & 4 & 4 & 4 & $4 / 1$ & 18 \\
\hline ST2-F & & & & 1 & & 1 \\
\hline Subtotal-F & & & & & & \\
\hline
\end{tabular}

\begin{tabular}{|l|c|l|l|l|l|l|}
\hline $10-\mathrm{G}$ & 1 & & & & & 1 \\
\hline $15-\mathrm{G}$ & & & & 1 & & 1 \\
\hline $43-\mathrm{G}$ & 1 & & & & & 1 \\
\hline Subtotatal-G & 2 & & & 1 & & 3 \\
\hline
\end{tabular}

\begin{tabular}{|l|c|c|l|l|l|l|}
\hline $15-\mathrm{H}$ & 1 & 2 & & & $1 / 1$ & 4 \\
\hline $43-\mathrm{H}$ & 1 & & & & & 1 \\
\hline Subtotal-H & 2 & 2 & & & $1 / 1$ & 5 \\
\hline
\end{tabular}

\begin{tabular}{|l|l|l|l|l|l|l|}
\hline $43-\mathrm{I}$ & & 1 & & & & 1 \\
\hline
\end{tabular}

\begin{tabular}{|l|l|l|l|l|l|l|}
\hline $43-\mathrm{J}$ & & 1 & & & & 1 \\
\hline
\end{tabular}

\begin{tabular}{|l|c|c|c|c|c|c|}
\hline SITE TOTALS & 130 & $98 / 1$ & 94 & $65 / 1$ & $58 / 12$ & 445 \\
\hline
\end{tabular}

Bs $=$ Bone, sparse $\quad \mathbf{B m}=$ Bone, moderate $\quad \mathbf{B p}=$ Bone, profuse $\quad \mathbf{S p}=$ Sandy paste 
Appendix III:

41KA26-B Rim Sherds and Decorated Sherds 
Appendix III: Rim sherds and decorated sherds

\begin{tabular}{|c|c|c|c|c|c|c|c|c|}
\hline Provenience & Decoration & Rim Profile & Lip & $\begin{array}{c}\text { Oxidation } \\
\text { Conditions } *\end{array}$ & Temper & Paste & $\begin{array}{c}\text { Surface } \\
\text { Treatment }\end{array}$ & $\begin{array}{c}\text { Thickness } \\
(\mathrm{mm})\end{array}$ \\
\hline $6-\mathrm{A}$ & - & direct & rounded/thinned & $\mathrm{H}$ & $\mathrm{Bs}$ & Clay & - & 7.6 \\
\hline $6-\mathrm{A}$ & - & direct & rounded/thinned & $\mathrm{B}$ & $\mathrm{Bm}$ & Clay & - & 6.9 \\
\hline $49-\mathrm{A}$ & - & $\begin{array}{c}\text { folded exterior, } \\
\text { direct } \\
\end{array}$ & rounded & $\mathrm{G}$ & $\mathrm{Bp}$ & Clay & - & 5.3 \\
\hline $49-\mathrm{A}$ & - & inverted & rounded & $\mathrm{F}$ & Bs & Clay & - & 5.6 \\
\hline $33-\mathrm{B}$ & - & $\begin{array}{c}\text { direct, folded } \\
\text { exterior }\end{array}$ & rounded & $\mathrm{F}$ & $\mathrm{Bp}$ & Clay & - & 4.1 \\
\hline $33-\mathrm{B}$ & - & direct & rounded & $E$ & $\mathrm{Bp}$ & Clay & - & 6.4 \\
\hline $33-B$ & - & direct & rounded & $\mathrm{E}$ & Bs & Clay & - & 6.4 \\
\hline $33-\mathrm{B}$ & - & direct & flat & $\mathrm{H}$ & $\mathrm{Bm}$ & Clay & - & 4.6 \\
\hline $47-B$ & - & $\begin{array}{c}\text { direct, folded } \\
\text { exterior }\end{array}$ & flat & $\mathrm{F}$ & $\mathrm{Bm}$ & Clay & - & 5.3 \\
\hline $47-\mathrm{B}$ & - & direct & rounded & $\mathrm{B}$ & $\mathrm{Bp}$ & Clay & - & 5.6 \\
\hline $6-\mathrm{C}$ & - & direct & $\begin{array}{c}\text { flat, interior } \\
\text { beveled }\end{array}$ & $\mathrm{B}$ & $\mathrm{Bm}$ & Clay & - & 5.1 \\
\hline $56-\mathrm{C}$ & - & direct, folded interior & rounded & $\mathrm{G}$ & $\mathrm{Bm}$ & Clay & - & 4.1 \\
\hline $56-\mathrm{C}$ & - & $\begin{array}{c}\text { direct, folded } \\
\text { exterior }\end{array}$ & rounded & $\mathrm{H}$ & $\mathrm{Bm}$ & Clay & - & 5.1 \\
\hline $3-\mathrm{D}$ & $\begin{array}{c}\text { Overlapping } \\
\text { brushed }\end{array}$ & - & - & $\bar{A}$ & $\mathrm{Bs}$ & Clay & - & 5.3 \\
\hline 9-D & - & direct & rounded & $\mathrm{B}$ & - & SP & - & 8.4 \\
\hline 9-D & - & everted & rounded & $\mathrm{B}$ & - & SP & - & 8.2 \\
\hline 49-D & - & direct & rounded & $\mathrm{B}$ & Bs & Clay & - & 3.8 \\
\hline 49-D & - & everted & rounded & $\mathrm{F}$ & $\mathrm{Bp}$ & Clay & - & 5.4 \\
\hline 56-D & - & direct, folded interior & rounded & B & Bs & Clay & - & 5.9 \\
\hline $43-\mathrm{E}$ & - & direct & rounded & $\bar{E}$ & $\mathrm{Bm}$ & Clay & $\begin{array}{c}\text { Interior } \\
\text { Burnished } \\
\end{array}$ & 4.6 \\
\hline $52-\mathrm{E}$ & - & expanding, direct & rounded & $\mathrm{A}$ & $\mathrm{Bs}$ & Clay & $\begin{array}{c}\text { Interior } \\
\text { Asphaltum } \\
\end{array}$ & 4.6 \\
\hline $56-\mathrm{E}$ & - & direct & rounded & B & Bs & Clay & $\begin{array}{c}\text { Exterior } \\
\text { Burnished } \\
\end{array}$ & 7.4 \\
\hline $7-\mathrm{F}$ & $\begin{array}{l}\text { possible } \\
\text { pipe bowl } \\
\text { sherd }\end{array}$ & - & - & $\mathrm{H}$ & - & $\mathrm{SP}$ & - & 1.3 \\
\hline
\end{tabular}

* Key for oxidation condition:

$\mathrm{A}=$ oxidized

$\mathrm{B}=$ reduced

$\mathrm{C}-\mathrm{E}=$ incompletely oxidized

$\mathrm{F}-\mathrm{H}=$ reduced 


\section{Appendix IV: \\ 41KA26-B Sherds for Neutron Activation Analysis}


Appendix IV: 41KA26-B Sherds for Neutron Activation Analysis

\begin{tabular}{|c|c|c|c|c|c|c|c|}
\hline Provenience & NAA \# & Sherd Type & $\begin{array}{l}\text { Oxidation } \\
\text { Conditions }\end{array}$ & Temper & Paste & Surface Treatment & $\begin{array}{l}\text { Thickness } \\
(\mathrm{mm})\end{array}$ \\
\hline $52-\mathrm{E}$ & 201 & body & A & - & SP-s & Interior asphaltum & 5.9 \\
\hline $52-\mathrm{E}^{*}$ & $202 *$ & body* & $\mathrm{H}$ & $\mathrm{Bp}$ & Clay & - & 6.4 \\
\hline 29-B & 203 & body & $\mathrm{E}$ & $\mathrm{B} \mathrm{s}$ & Clay & $\begin{array}{l}\text { interior/exterior } \\
\text { smoothed }\end{array}$ & 8.9 \\
\hline 29-E & 204 & body & B & $\mathrm{Bp}$ & Clay & Ext. smoothed & 7.2 \\
\hline 13-D & 205 & body & G & B s-hematite & Clay & Interior asphaltum & 7.9 \\
\hline 13-D & 206 & body & $\mathrm{E}$ & $\mathrm{Bs}$ & Clay & Ext. scraped & 8.7 \\
\hline 13-D & 207 & body & $\mathrm{F}$ & $\mathrm{Bm}$ & Clay & - & 4.8 \\
\hline $31-\mathrm{D}$ & 208 & body & B & $\mathrm{Bs}$ & Clay & Ext. smoothed & 7.4 \\
\hline $51-\mathrm{C}$ & 209 & body & $\mathrm{F}$ & $\mathrm{Bp}$ & Clay & - & 6.4 \\
\hline $43-\mathrm{F}$ & 210 & body & $\mathrm{H}$ & $\mathrm{Bp}$ & Clay & - & 9.1 \\
\hline $5-3$ & 211 & body & $\mathrm{C}$ & $\mathrm{Bp}$ & Clay & - & 8.2 \\
\hline $50-\mathrm{C}$ & 212 & body & $\mathrm{F}$ & $\mathrm{Bp}$ & Clay & - & 7.2 \\
\hline 14-D & 213 & body/base & B & - & SP & - & 10.5 \\
\hline 3B-B & 214 & body & B & $\mathrm{Bp}$ & Clay & - & 5.6 \\
\hline $57-C$ & 215 & body & G & $\mathrm{Bp}$ & Clay & - & 5.1 \\
\hline $56-\mathrm{E}$ & 216 & rim & B & $\mathrm{B} \mathrm{s}$ & Clay & - & 7.4 \\
\hline 47-B & 217 & body & $\mathrm{H}$ & $\mathrm{Bs}$ & Clay & - & 6.1 \\
\hline 47-B & 218 & body/base & $\mathrm{F}$ & $\mathrm{Bm}$ & Clay & - & 8.7 \\
\hline 47-B & 219 & body & $\mathrm{F}$ & $\mathrm{Bp}$ & Clay & - & 6.4 \\
\hline 44-C & 220 & body & $\mathrm{F}$ ? & $\mathrm{Bm}$ & Clay & Ext. scraped & 5.4 \\
\hline $35-\mathrm{C}$ & 221 & body & $?$ & $\mathrm{Bs}$ & Clay & - & 7.4 \\
\hline
\end{tabular}

* From vessel section 1 


\section{Appendix V: \\ Instrumental Neutron Activations Analysis of Ceramics}




\section{Appendix V: Instrumental Neutron Activations Analysis of Ceramics}

\section{Hector Neff and Michael D. Glascock}

\section{Introduction}

Instrumental neutron activation analysis (INAA) was recently completed on a sample of 21 ceramics from 41KA26-B, an archaeological site in Karnes County in southern Texas. The analyses were undertaken at the University of Missouri Research Reactor Center (MURR) in support of a project carried out by the Center for Archaeological Research, The University of Texas, San Antonio. Here, we describe sample preparation and analytical techniques used at MURR and report the subgroup structure identified through quantitative analysis of the ceramic compositional data set.

\section{Background}

The analyses reported here were originally carried out in conjunction with an investigation of lead-glazed and Native American pottery from Mission Refugio (41RF1). The question being addressed by the larger project is whether there was any overlap in the raw materials used for the two types of pottery. Here, we report the subgroup structure identified in the 41KA26 sample, which consists exclusively of Native American pottery. A broader regional context for interpretation of the results is provided by the larger sample of pottery from Mission Refugio.

\section{Sample Preparation}

The ceramics were prepared for INAA using standard MURR procedures. The clay sample was fired to 700 degrees for one hour in air before being prepared for analysis. Pieces of each sherd were burred with a silicon carbide burr to remove painted or slipped surfaces and adhering soil. The burred sherd samples and the clay test tile were then washed with deionized water and allowed to air dry. These were then crushed in an agate mortar to yield a fine powder. Part of each specimen was retained, unpowdered, for the MURR archive of analyzed ceramic fabrics.
The powder samples were oven-dried at 100 degrees $C$ for 24 hours. Portions of approximately $150 \mathrm{mg}$ were weighed and placed in small polyvials used for short irradiations. At the same time, $200 \mathrm{mg}$ of each sample were weighed into high-purity quartz vials used for long irradiations. Along with the unknown samples, reference standards of SRM-1633a (coal fly ash) and SRM-688 (basalt rock) were similarly prepared, as were quality control samples (i.e., standards treated as unknowns) of SRM-278 (obsidian rock) and Ohio Red Clay.

\section{Irradiation and Gamma-Ray Spectroscopy}

Neutron activation analysis of ceramics at MURR, which consists of two irradiations and a total of three gamma counts, constitutes a superset of the procedures used at most other laboratories (Glascock 1992; Neff 1992). As discussed in detail by Glascock (1992), a short irradiation is carried out through the pneumatic tube irradiation system. Samples in the polyvials are sequentially irradiated, two at a time, for five seconds at a neutron flux of $8 \times 10^{13} \mathrm{n} / \mathrm{cm}^{2} / \mathrm{s}$. The 720 -second count yields gamma spectra containing peaks for the short-lived elements aluminum ( $\mathrm{Al})$, barium $(\mathrm{Ba})$, calcium (Ca), dysprosium (Dy), potassium (K), manganese $(\mathrm{Mn})$, sodium $(\mathrm{Na})$, titanium $(\mathrm{Ti})$, and vanadium (V). The samples encapsulated in quartz vials are subjected to a 24-hour irradiation at a neutron flux of $5 \times 10^{13} \mathrm{n} / \mathrm{cm}^{2} / \mathrm{s}$. This long irradiation is analogous to the single irradiation utilized at most other laboratories. After the long irradiation, samples decay for seven days, then are counted for 2,000 seconds (the "middle count") on a high-resolution germanium detector coupled to an automatic sample changer. The middle count yields determinations of seven medium half life elements, namely arsenic (As), lanthanum (La), lutetium ( $\mathrm{Lu})$, neodymium $(\mathrm{Nd})$, samarium $(\mathrm{Sm})$, uranium $(\mathrm{U})$, and ytterbium $(\mathrm{Yb})$. After an additional three- or four-week decay, a final count of 9,000 seconds is carried out on each sample. The latter measurement yields the following 17 long half life elements: cerium (Ce), cobalt (Co), chromium 
$(\mathrm{Cr})$, cesium $(\mathrm{Cs})$, europium $(\mathrm{Eu})$, iron $(\mathrm{Fe})$, hafnium (Hf), nickel (Ni), rubidium ( $\mathrm{Rb}$ ), antimony ( $\mathrm{Sb}$ ), scandium ( $\mathrm{Sc}$ ), strontium ( $\mathrm{Sr}$ ), tantalum $(\mathrm{Ta})$, terbium $(\mathrm{Tb})$, thorium $(\mathrm{Th})$, zinc $(\mathrm{Zn})$, and zirconium $(\mathrm{Zr})$.

Elemental concentration data from the two irradiations and three counts (a total of 33 elements) are assembled into a single tabulation and stored in a dBASE III file along with descriptive information available for each sample.

\section{Quantitative Analysis of the Chemical Data}

The analyses at MURR described previously produced elemental concentration values for 32 or 33 elements in most of the analyzed samples. (Some elements, especially nickel, were below detection in some samples.) Quantitative analysis was subsequently carried out on base 10 logarithms of concentrations for these data. Use of log concentrations instead of raw data compensates for differences in magnitude between major elements, such as iron, on one hand and trace elements, such as the rare earth or lanthanide elements, on the other hand. Transformation to base 10 logarithms also yields a more nearly normal distribution for many trace elements.

In the present case, an additional transformation was necessary because of the presence of large amounts of bone temper in some of the analyzed specimens. Assuming that bone is composed largely of calcium carbonate, a correction developed for shell-tempered pottery by Blackman (Cogswell et al. 1998; Steponaitis et al. 1996) removes the effect of bone temper from heavily tempered specimens. The correction is:

$$
e^{\prime}=\left(10^{6} e\right) /\left(10^{6}-2.5 c\right)
$$

\section{Equation 1}

where $e=$ is the corrected concentration of any element in ppm, $e$ is the measured concentration of that element in $\mathrm{ppm}$, and $c$ is the amount of calcium in ppm. This correction obviously does not apply to elements that are present in high concentrations in calcium carbonates, including strontium and barium. In the present case, calcium, strontium, and barium were excluded from the quantitative data analysis after correcting the other data for addition of temper. It is also worth noting that this transformation will always over-correct because some calcium is naturally present in all clay. Nonetheless, experiments by Cogswell et al. (1998) demonstrate that the true clay chemical similarities of calcium carbonate tempered ceramics can be recovered very confidently after applying this correction.

The goal of quantitative analysis of the chemical data is to recognize compositionally homogeneous groups within the analytical database. Based on the "provenance postulate" (Weigand et al. 1977), such groups are assumed to represent geographically restricted sources or source zones. The location of sources or source zones may be inferred by comparing the unknown groups to knowns (source raw materials) or by indirect means. Such indirect means include the "criterion of abundance" (Bishop et al. 1982), arguments based on geological and sedimentological characteristics (e.g., Steponaitis et al. 1996), and identifying similarities to other ceramics whose sources may be inferred with some confidence.

In the present case, subgroups were relatively easy to discern by inspection of bivariate plots of the 41KA26$B$ data together with the larger sample of analyses from Mission Refugio. The largest of the subgroups identified by these means could be evaluated statistically by calculating Mahalanobis distances of individual specimens to the group centroid. The Mahalanobis distance of a specimen from a group centroid (Bieber et al. 1976; Bishop and Neff 1989; Harbottle 1976; Sayre 1975) is:

$$
D_{y, X}^{2}=[y \bar{X}]_{x}^{t} I_{x}[y \bar{X}]
$$

\section{Equation 2}

where $y$ is $1 \mathrm{x}$ m array of logged elemental concentrations for the individual point of interest, $X$ is the $\mathrm{n} \times \mathrm{m}$ data matrix of logged concentrations for the group to which the point is being compared with being its $1 \mathrm{x} \mathrm{m}$ centroid, and $I_{x}$ is the inverse of the $\mathrm{m}$ 
$\mathrm{x} \mathrm{m}$ variance-covariance matrix of group $X$. Because Mahalanobis distance takes into account variances and covariances in the multivariate group it is analogous to expressing distance from a univariate mean in standard deviation units. Like standard deviation units, Mahalanobis distances can be converted into probabilities of group membership for each individual specimen (e.g., Bieber et al. 1976; Bishop and Neff 1989; Harbottle 1976). For relatively small sample sizes, it is appropriate to base probabilities on Hotelling's $\mathrm{T}^{2}$, which is a multivariate extension of the univariate Student's t.

With small groups, Mahalanobis distance-based probabilities of group membership may fluctuate dramatically depending on whether or not each specimen is assumed to be a member of the group to which it is being compared. Harbottle (1976) calls this phenomenon "stretchability" in reference to the tendency of an included specimen to stretch the group in the direction of its own location in the elemental concentration space. This problem can be circumvented by cross-validation (or "jackknifing"), that is, by removing each specimen from its presumed group before calculating its own probability of membership (Baxter 1994; Leese and Main 1994). This is a conservative approach to group evaluation that may sometimes exclude true group members. All probabilities discussed below are cross-validated.

For specimens that cannot be assigned to groups, a tactic that sometimes proves useful for assessing provenance is to scan a comparison databank in order to identify individual specimens that are compositionally similar to the individual specimens in the data set of interest. The technique is straightforward: Euclidean (straight-line) distances are calculated between a given individual specimen and all specimens in the comparison databank, and the top 10 specimens are extracted for comparison. Actually, the distance measure for which minima are sought is the average Euclidean distance:

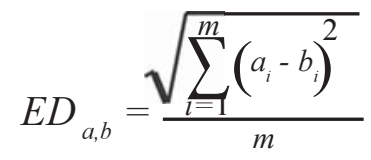

\section{Equation 3}

where $a$ and $b$ are vectors containing $m$ elemental concentrations for the two individual specimens being compared.

\section{Results}

Thirteen of the 41KA26-B specimens unquestionably cluster with the Refugio Mission Reference Group, whether the original logged data are used (Figure V1) or the data are adjusted for the addition of bone temper (Figure V-2). Calculation of Mahalanobis distances from the group centroid also places these thirteen specimens included in the reference group (Table V-1, Page 127, last two columns).

The importance of compensating for the effect of temper is also illustrated clearly by the southern Texas data. With no correction for added bone temper, six of the specimens from 41KA26-B appear to form a distinct subgroup that is enriched in many elements compared to the Refugio Mission Reference Group (e.g., Figure $\mathrm{V}-1)$. These six specimens all show less than $0.0005 \%$ probability of membership in the Refugio Mission Reference Group based on the original logged elemental concentration data (Table V-1, Page 127, second to last column). In the absence of additional analysis, the most parsimonious interpretation of these results would be that the six specimens represent imports from a region where Refugio Mission Reference Group members were made. 


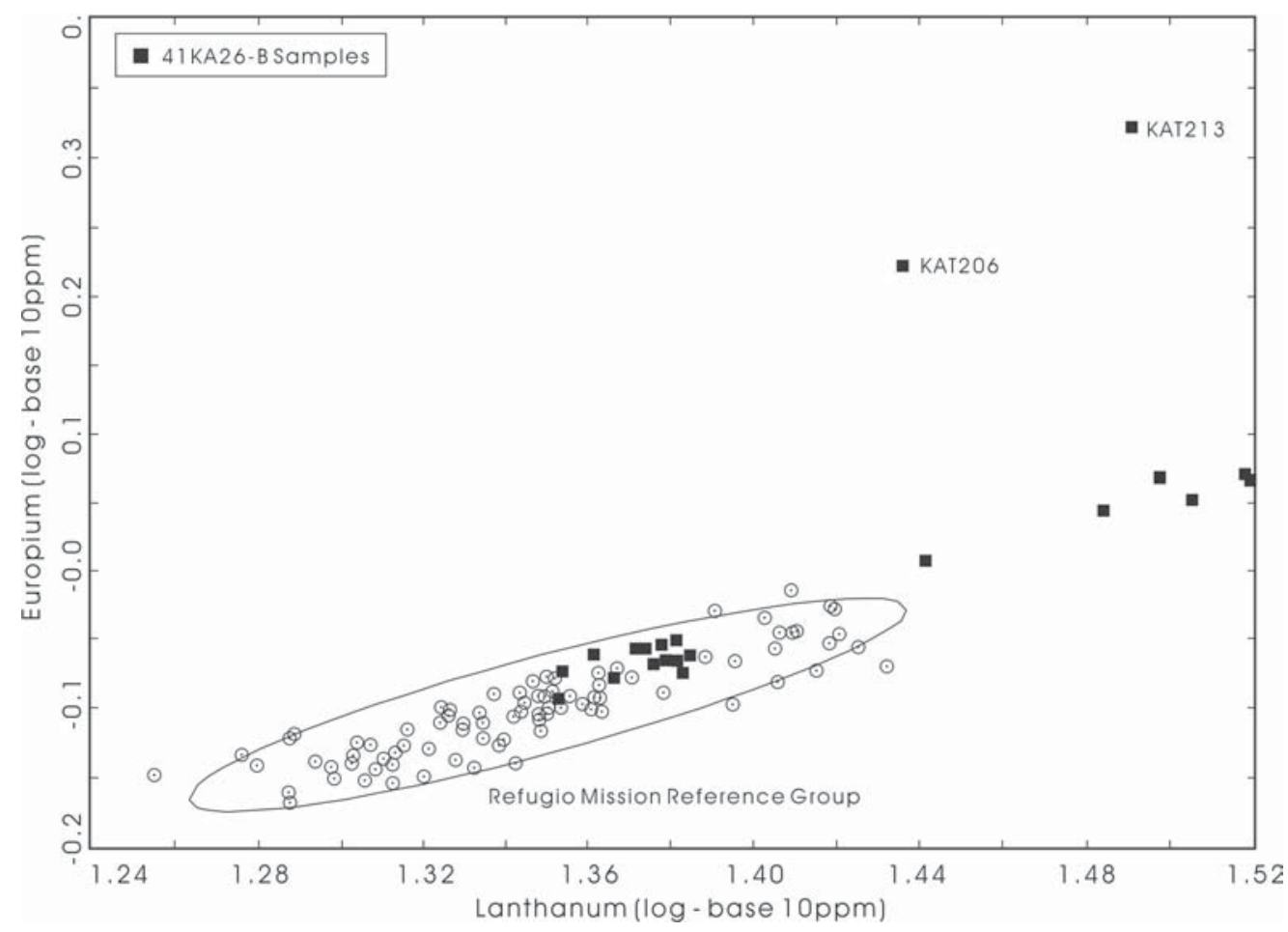

Figure V-1. Logged Data prior to adjustment for bone temper.

Plot of lanthanum and europium concentrations in Native American pottery from southern Texas before transforming the data to eliminate the effect of bone temper. Ellipse represents $90 \%$ confidence level for membership in the Refugio Mission Reference Group.

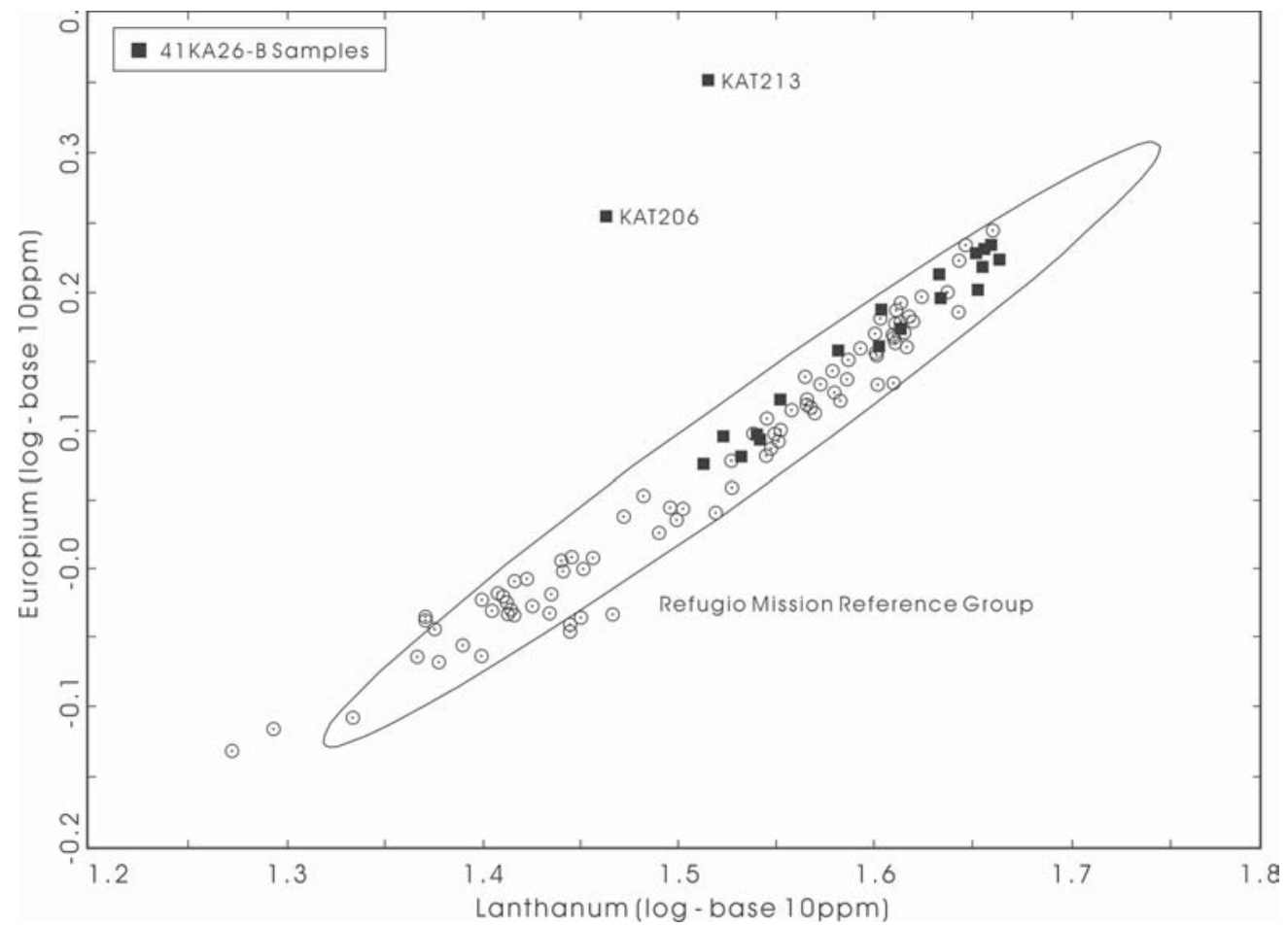

Figure V-2. Logged Data after adjustment for bone temper.

Plot of lanthanum and europium concentrations in Native American pottery from southern Texas after compensating for the effect of bone temper. Ellipse represents $90 \%$ confidence level for membership in the Refugio Mission Reference Group. 
Table V-1. Chemical Components

\begin{tabular}{|c|c|c|c|c|c|c|c|c|c|c|c|}
\hline anid & prov & chem99_1 & chem99_2 & as & la & lu & nd & $\mathrm{sm}$ & $\mathrm{u}$ & $y b$ & ce \\
\hline KAT201 & $52-E$ & 41KA26-B Group & Unassigned & 5.5323 & 27.7225 & 0.3148 & 24.7704 & 4.7994 & 3.265 & 2.1815 & 57.3795 \\
\hline КAT202 & $52-\mathrm{E}$ & Refugio Ref. Group & Refugio Ref. Group & 5.8644 & 23.6951 & 0.2319 & 17.9544 & 4.2 & 2.052 & 1.9039 & 49.9146 \\
\hline KAT203 & 29-B & 41KA26-B Group & Refugio Ref. Group & 8.5323 & 32.9993 & 0.3277 & 28.1914 & 5.6438 & 2.35 & 2.7754 & 66.1476 \\
\hline KAT204 & 29-E & Refugio Ref. Group & Refugio Ref. Group & 7.3141 & 22.5634 & 0.2474 & 18.9034 & 4.0778 & 2.267 & 1.6292 & 45.4058 \\
\hline KAT205 & $13-D$ & 41KA26-B Group & Refugio Ref. Group & 8.2065 & 32.9233 & 0.3443 & 23.8485 & 5.7085 & 1.984 & 2.5549 & 66.027 \\
\hline KAT206 & $13-D$ & Unassigned & Unassigned & 4.5702 & 27.4512 & 0.3873 & 28.1712 & 6.4431 & 2.649 & 2.851 & 57.8684 \\
\hline KAT207 & 13-D & Refugio Ref. Group & Refugio Ref. Group & 6.3921 & 24.1043 & 0.2184 & 23.7946 & 4.3483 & 1.586 & 2.1414 & 50.4534 \\
\hline KAT208 & $31-D$ & Refugio Ref. Group & Refugio Ref. Group & 6.8589 & 23.2883 & 0.2214 & 20.8066 & 4.221 & 2.072 & 1.7983 & 49.1067 \\
\hline KAT209 & $51-\mathrm{C}$ & Refugio Ref. Group & Refugio Ref. Group & 5.8763 & 23.9143 & 0.2976 & 17.8958 & 4.3379 & 2.043 & 1.6957 & 52.4452 \\
\hline KAT210 & $43-\mathrm{F}$ & Refugio Ref. Group & Refugio Ref. Group & 6.3644 & 24.1919 & 0.2438 & 22.0848 & 4.4027 & 1.79 & 2.0943 & 50.0425 \\
\hline KAT211 & VIII-3 & 41KA26-B Group & Refugio Ref. Group & 7.6062 & 30.5775 & 0.334 & 28.569 & 5.3167 & 2.418 & 2.7014 & 61.192 \\
\hline KAT212 & $50-\mathrm{C}$ & Refugio Ref. Group & Refugio Ref. Group & 6.1416 & 24.104 & 0.2303 & 22.4776 & 4.3135 & 1.848 & 1.7714 & 49.9308 \\
\hline KAT213 & $14-\mathrm{D}$ & Unassigned & Unassigned & 3.1206 & 31.1853 & 0.4418 & 39.2535 & 8.8182 & 2.574 & 3.391 & 67.5513 \\
\hline KAT214 & 3B-B & Refugio Ref. Group & Refugio Ref. Group & 4.7478 & 22.6303 & 0.2021 & 23.0442 & 3.9892 & 1.602 & 1.9211 & 46.7703 \\
\hline KAT215 & $57-\mathrm{C}$ & Refugio Ref. Group & Refugio Ref. Group & 7.0572 & 23.0313 & 0.2416 & 19.2913 & 4.1541 & 1.684 & 1.8482 & 48.8055 \\
\hline KAT216 & $56-\mathrm{E}$ & 41KA26-B Group & Refugio Ref. Group & 6.2208 & 32.1213 & 0.3647 & 32.1569 & 5.4975 & 2.049 & 2.7665 & 64.2939 \\
\hline KAT217 & $47-B$ & Refugio Ref. Group & Refugio Ref. Group & 6.9951 & 23.8009 & 0.2741 & 18.5966 & 4.3339 & 1.224 & 1.7765 & 49.7565 \\
\hline KAT218 & 47-B & 41KA26-B Group & Refugio Ref. Group & 7.4856 & 31.5667 & 0.3215 & 25.0665 & 5.4058 & 1.941 & 2.6054 & 65.9013 \\
\hline KAT219 & $47-B$ & Refugio Ref. Group & Refugio Ref. Group & 7.2406 & 23.9708 & 0.2432 & 21.4764 & 4.2942 & 1.995 & 2.0091 & 50.3026 \\
\hline KAT220 & $44-C$ & Refugio Ref. Group & Refugio Ref. Group & 5.9788 & 24.2871 & 0.2678 & 24.6785 & 4.4047 & 2.658 & 1.9088 & 50.8906 \\
\hline KAT221 & $35-C$ & Refugio Ref. Group & Refugio Ref. Group & 6.3016 & 23.5749 & 0.2625 & 20.5563 & 4.3655 & 1.827 & 1.5966 & 50.6082 \\
\hline
\end{tabular}

\begin{tabular}{|c|c|c|c|c|c|c|c|c|c|c|c|}
\hline anid & prov & chem99_1 & chem99_2 & co & $\mathrm{cr}$ & cs & $\mathrm{eu}$ & fe & hf & ni & $\mathrm{rb}$ \\
\hline KAT201 & $52-E$ & 41KA26-B Group & Unassigned & 7.8601 & 44.1738 & 4.5788 & 1.016 & 21666 & 6.0115 & 0 & 56.6787 \\
\hline KAT202 & $52-E$ & Refugio Ref. Group & Refugio Ref. Group & 8.0334 & 36.9568 & 4.4533 & 0.8746 & 22989.1 & 3.4078 & 0 & 60.3655 \\
\hline KAT203 & $29-B$ & 41KA26-B Group & Refugio Ref. Group & 11.064 & 52.1838 & 5.9162 & 1612 & 29900.3 & 6.8989 & 0 & 94.0625 \\
\hline KAT204 & $29-E$ & Refugio Ref. Group & Refugio Ref. Group & 7.5794 & 36.2997 & 3.4272 & 43 & 224 & 33 & 27.7 & 53.1935 \\
\hline KAT205 & $13-D$ & 41KA26-B Group & Refugio Ref. Group & 68 & 52. & 3637 & & 3075 & 3985 & 0 & 3285 \\
\hline KAT206 & $13-D$ & Unassigned & Unassigned & 7.5163 & 15.8582 & 2.7583 & 1.666 & 34397 & 4.7966 & 0 & 102.6692 \\
\hline KAT207 & $13-D$ & Refugio Ref. Group & Refugio Ref. Group & 7.9419 & 38.9913 & 5.0928 & 0.8869 & 24149 & 3.9658 & 0 & 67.4388 \\
\hline КAT208 & $31-D$ & Refugic & f. Group & 8.6 & 38 & 58 & & & & 0 & 404 \\
\hline KAT209 & $51-\mathrm{C}$ & Group & Group & & & & & & & 0 & 649 \\
\hline KAT210 & $43-\mathrm{F}$ & Refugio Ref. Group & Ref. Group & 7.9652 & 38.9609 & 4.8 & 05 & 23629.5 & & 0 & 64.8412 \\
\hline KAT211 & VIII-3 & 41KA26-B Group & f. Group & 10.5691 & 51. & 5.5 & 49 & 29334.5 & 7. & 0 & 90.8752 \\
\hline KAT212 & $50-\mathrm{C}$ & Group & Group & & & & & 22.4 & & 0 & 67.8319 \\
\hline KAT213 & 14-D & Unas & Unas & 7.5 & 17 & 3. & 2. & 9.1 & & 0 & 107.8685 \\
\hline KAT214 & $3 B-B$ & Refugio Ref. Group & Refugio Ref. Group & 7.6995 & & & & & & 0 & 61.0788 \\
\hline KAT215 & $57-C$ & Refugio Ref. Group & f. Group & 9.2227 & 36.8817 & & 0.8672 & 23059.3 & 3.8 & 29.4 & 52.8114 \\
\hline KAT216 & $56-\mathrm{E}$ & 41KA26-B Group & f. Group & 11.0356 & 51.7 & 4. & 24 & 1.2 & 27 & 0 & 82.7702 \\
\hline KAT217 & $47-B$ & Refugio Ref. Group & Refugio Ref. Group & 8.6325 & 39.396 & 4.9584 & 0.8528 & 23574.5 & 3.805 & 0 & 66.7123 \\
\hline KAT218 & $47-B$ & 41KA26-B Group & Refugio Ref. Group & 11.229 & & & & 30185.6 & & 0 & 90.1835 \\
\hline KAT219 & $47-B$ & Refugio Ref. Group & Refugio Ref. Group & 8.2124 & 38.7784 & 5.009 & 0.8583 & 24025.6 & 3.9805 & 0 & 68.4046 \\
\hline KAT220 & $44-C$ & Refugio Ref. Group & Refugio Ref. Group & 7.9385 & 38.8585 & 3.0693 & 0.865 & 23755.8 & 3.648 & 0 & 48.1442 \\
\hline KAT221 & $35-C$ & Refugio Ref. Group & Refugio Ref. Group & 8.1467 & 39.1706 & 3.2239 & 0.8743 & 23881.8 & 3.8135 & 0 & 48.6428 \\
\hline
\end{tabular}

\begin{tabular}{|c|c|c|c|c|c|c|c|c|c|c|c|}
\hline anid & prov & chem99_1 & chem99_2 & $\mathrm{sb}$ & $\mathrm{sc}$ & $\mathrm{sr}$ & ta & tb & th & $\mathrm{zn}$ & $\mathrm{zr}$ \\
\hline KAT201 & $52-E$ & 41KA26-B Group & Unassigned & 0.8814 & 9.2042 & 262 & 0.9185 & 0.5949 & 9.5051 & 47.6735 & 159.2327 \\
\hline KAT202 & $52-E$ & Refugio Ref. Group & Refugio Ref. Group & 0.4647 & 6.9955 & 244.7 & 0.7203 & 0.5085 & 7.4359 & 66.914 & 96.9952 \\
\hline KAT203 & $29-B$ & 41KA26-B Group & Refugio Ref. Group & 0.6354 & 9.1232 & 96.5 & 0.9082 & 0.7742 & 9.9543 & 67.5499 & 172.2021 \\
\hline KAT204 & $29-E$ & Refugio Ref. Group & Refugio Ref. Group & 0.5478 & 6.7929 & 241 & 0.6449 & 0.5294 & 7.1703 & 58.7922 & 115.8008 \\
\hline KAT205 & 13-D & 41KA26-B Group & Refugio Ref. Group & 0.6951 & 9.2536 & 92.8 & 0.9373 & 0.7432 & 9.9331 & 66.6578 & 197.5825 \\
\hline KAT206 & 13-D & Unassigned & Unassigned & 0.5558 & 6.6105 & 653.8 & 0.9201 & 0.7807 & 7.5058 & 51.0397 & 145.4189 \\
\hline KAT207 & 13-D & Refugio Ref. Group & Refugio Ref. Group & 0.5183 & 7.4247 & 253.9 & 0.6992 & 0.648 & 7.8728 & 72.2767 & 103.7636 \\
\hline KAT208 & $31-D$ & Refugio Ref. Group & Refugio Ref. Group & 0.5699 & 7.2383 & 273.7 & 0.6818 & 0.5998 & 7.556 & 73.2518 & 158.8667 \\
\hline KAT209 & $51-C$ & Refugio Ref. Group & Refugio Ref. Group & 0.4813 & 7.1957 & 238.2 & 0.7219 & 0.6291 & 7.6443 & 77.2642 & 115.9104 \\
\hline KAT210 & $43-\mathrm{F}$ & Refugio Ref. Group & Refugio Ref. Group & 0.5576 & 7.2398 & 241.8 & 0.7271 & 0.6721 & 7.5199 & 72.3789 & 124.5634 \\
\hline KAT211 & VIII-3 & 41KA26-B Group & Refugio Ref. Group & 0.6576 & 8.8756 & 117.2 & 0.8751 & 0.7555 & 9.3046 & 77.7974 & 188.9098 \\
\hline KAT212 & $50-C$ & Refugio Ref. Group & Refugio Ref. Group & 0.5552 & 7.2712 & 241 & 0.7147 & 0.5672 & 7.6373 & 76.7725 & 112.8502 \\
\hline KAT213 & 14-D & Unassigned & Unassigned & 1.1268 & 6.7811 & 672.4 & 1.1487 & 1.1225 & 7.7791 & 52.5626 & 147.6453 \\
\hline KAT214 & 3B-B & Refugio Ref. Group & Refugio Ref. Group & 0.4708 & 6.8844 & 238.7 & 0.6584 & 0.5062 & 7.1569 & 66.0722 & 124.6438 \\
\hline KAT215 & $57-C$ & Refugio Ref. Group & Refugio Ref. Group & 0.515 & 7.0285 & 226.2 & 0.6624 & 0.4865 & 7.508 & 64.2735 & 125.4336 \\
\hline KAT216 & $56-E$ & 41KA26-B Group & Refugio Ref. Group & 0.5895 & 8.8576 & 95 & 0.9946 & 0.704 & 10.3185 & 81.9636 & 207.4821 \\
\hline KAT217 & $47-B$ & Refugio Ref. Group & Refugio Ref. Group & 0.6052 & 7.2451 & 297 & 0.7118 & 0.5756 & 7.6115 & 101.2766 & 102.5816 \\
\hline KAT218 & $47-B$ & 41KA26-B Group & Refugio Ref. Group & 0.6503 & 9.1788 & 98.2 & 0.9453 & 0.7579 & 9.895 & 64.2445 & 188.4108 \\
\hline KAT219 & $47-B$ & Refugio Ref. Group & Refugio Ref. Group & 0.5398 & 7.4084 & 282.9 & 0.7416 & 0.5933 & 7.6763 & 69.2637 & 107.8186 \\
\hline KAT220 & $44-C$ & Refugio Ref. Group & Refugio Ref. Group & 0.5699 & 7.2578 & 216.5 & 0.7254 & 0.574 & 7.7539 & 57.8425 & 111.4058 \\
\hline KAT221 & $35-C$ & Refugio Ref. Group & Refugio Ref. Group & 0.5185 & 7.3009 & 269.7 & 0.7227 & 0.6145 & 7.7907 & 57.9577 & 89.5224 \\
\hline
\end{tabular}


Table V-1, continued...

\begin{tabular}{|c|c|c|c|c|c|c|c|c|c|c|c|c|}
\hline anid & prov & chem99_1 & chem99_2 & al & $\mathrm{ba}$ & $\mathrm{ca}$ & dy & $\mathrm{k}$ & $\mathrm{mn}$ & na & $\mathrm{ti}$ & $\mathrm{v}$ \\
\hline KAT201 & $52-E$ & 41KA26-B Group & Unassigned & 65269.7 & 478.95 & 92673.8 & 3.6194 & 12230.9 & 230.05 & 2270.1 & 3914.73 & 81.0108 \\
\hline KAT202 & $52-E$ & Refugio Ref. Group & Refugio Ref. Group & 48757.7 & 429.18 & 192137.6 & 3.5195 & 10692.9 & 419.57 & 5646.1 & 2772.4 & 64.01 \\
\hline KAT203 & $29-B$ & 41KA26-B Group & Refugio Ref. Group & 64610.3 & 537.01 & 24724.2 & 4.4292 & 17680.4 & 20 & 42 & 3412.04 & 88.2786 \\
\hline КАТ204 & $29-E$ & Refugio Ref. Group & Refugio Ref. Group & 49820.6 & 59.35 & 183371.9 & & 11832.7 & & 3359 & 2143.7 & 67.4573 \\
\hline KAT205 & $13-D$ & 41KA26-B Group & Refugio Ref. Group & 63671.7 & 443.31 & 24334.7 & & 17756.1 & 253.26 & 4202.6 & 3259.03 & 90.2128 \\
\hline KAT206 & $13-D$ & Unassigned & Unassigned & 87769.2 & 662.14 & 28135.5 & 3.4662 & 24546.1 & 1021.46 & 18234.5 & 2648.04 & 100.9619 \\
\hline KAT207 & $13-D$ & Refugio Ref. Group & Refugio Ref. Group & 4.8 & 406.74 & 190530.3 & 3.4254 & 9504.1 & 490.81 & 4280.7 & 2238.51 & 65.5961 \\
\hline KAT208 & $31-D$ & ef. Group & Group & & & 1866 & & 112 & & & & 952 \\
\hline KAT210 & $43-\mathrm{F}$ & Refugio & Refugio & 515 & 365.86 & 187 & 3. & 105 & & 1 & 23 & 75.8429 \\
\hline KAT211 & VIII-3 & 41KA26 & Group & 3.9 & 553.1 & & & 17 & & & 33 & 94.5672 \\
\hline KAT212 & $50-C$ & Refugio Ref. & Refugio & & & 193 & & & & & 2437.54 & 71.7364 \\
\hline KAT213 & $14-D$ & Unassigned & Una & 94827.5 & 629.97 & 25862.5 & 4.7109 & 28819.4 & 1054.22 & 187 & 2140.77 & 86.2805 \\
\hline КАТ214 & $3 B-B$ & Refugio Ref. Group & Refugi & 47808.3 & & 192644.8 & 2.9594 & & 464.62 & & 1787.03 & 67.7726 \\
\hline KAT215 & $57-C$ & Group & Group & 75 & 544.94 & $173 \varepsilon$ & 3.08 & .7 & 3.2 & 3.7 & 16 & 61.7846 \\
\hline KAT216 & $56-E$ & 41KA26-B Group & Refugio Ref. Group & 60346.4 & 572.95 & 26286.1 & 3.5406 & 17533.2 & 196.16 & 3983.8 & 3166.96 & 90.2026 \\
\hline KAT217 & $47-B$ & Refugio Ref. Group & Refugio Ref. Group & 54625.7 & 418.86 & 192758.6 & 2.9732 & 10107.9 & 534.53 & 4362.4 & 2701.64 & 64.647 \\
\hline KAT220 & 44-C & Refugio Ref. Group & Refugio Ref. Group & 49826.6 & 683.64 & 160305.3 & 2.9152 & 13471.9 & 501.82 & 3135.3 & 2644.9 & 74.3592 \\
\hline KАТ221 & $35-C$ & Refugio Ref. Group & Refugio Ref. Group & 53656.3 & 600.72 & 155946 & 3.1244 & 14094.4 & 528.69 & 2922.3 & 1872.57 & 72.2934 \\
\hline
\end{tabular}

When allowance is made for the addition of bone temper to the southern Texas Native American pottery, the picture changes considerably. The six specimens originally placed in their own group now show concentrations more consistent with Refugio Mission Reference Group (Figure V-2). The reason for this change is that elemental concentrations in the Refugio Mission specimens (which are virtually all bone tempered) have been increased by applying Equation 1 , whereas the six specimens originally placed in the 41KA26-B Group, which are low in calcium, are little changed by the transformation. Using the transformed data, all but one of the specimens originally placed in the 41KA26-B group are now included in the Refugio Mission Reference Group at p-values ranging from $20 \%$ to $90 \%$ (Table V-1, above, last column). In all, 18 of the $2141 \mathrm{KA} 26-\mathrm{B}$ specimens would appear to derive from the same raw material source zone as the Mission Refugio Native American sample.

Without a larger sample of raw materials from southern Texas, some ambiguity surrounds the interpretation of the foregoing results. The fact that a raw clay sample from Refugio Mission matches the reference group suggests that at least some of the pottery in the group was made in the immediate vicinity of the Mission. On the other hand, there are at least two possible interpretations of the 18 specimens from 41KA26-B included in the reference group: either (1) the inhabitants of 41KA26-B obtained most of their pottery from sources near Mission Refugio or (2) the raw materials exploited by potters at 41KA26-B were similar in composition to those exploited by potters at Mission Refugio. The technological difference between the Mission and 41KA26 samples (i.e., greater reliance on bone temper and hence more consistent dilution of elements other than calcium at Mission Refugio) may suggest that there were distinct local ceramic traditions at the two locations. Such an inference in turn is most consistent with the view that both Mission Refugio and 41KA26$\mathrm{B}$ lie within the source zone represented by the Mission Refugio Reference Group. All in all, however, it is probably safest to conclude that the geographical extent of the source zone represented by the Mission Refugio Reference Group is unknown. 
Three of the 2141 KA26-B sherds remain unassigned even after compensating for the effect of added bone temper. One of these, KAT201, lies within the scatter of Refugio Mission Reference Group data points on most projections of the corrected data (e.g., Figure V2 ). Whether it is a statistical outlier that was produced locally or an import remains uncertain.

The other two unassigned specimens, KAT206 and KAT213, are chemically very different from all of the other southern Texas ceramics (e.g., Figure V-2). Although ceramics and raw materials from this region are not very well sampled, it seems unlikely KAT206 and KAT213, which differ so much from other southern Texas ceramics, originate in the same region. Euclidean searches of the entire MURR databank (which contains approximately 24,000 ceramics from many world regions) identified red wares from the Four Corners region as most closely similar to these two specimens. These similarities should not be read literally as indicating a source in the Four Corners area, but rather as evidence that KAT206 and KAT213 probably come from some as-yet poorly sampled zone within the Greater Southwest. That they are imports to 41KA26-B seems fairly certain.

\section{Conclusion}

This project, together with a related, larger project from Refugio Mission, have made some important initial steps toward understanding ceramic compositional variation of Native American and Colonial pottery from southern Texas. A local reference group has been defined, and probable imports to the region have been identified. The study has also revealed that technological variation (variable addition of bone temper) can create chemical variation that is unrelated to raw clay differences. A correction originally developed for shell temper appears to compensate adequately for the bone tempering effect.

\section{Acknowledgments}

Funding for this project was provided by the Texas Department of Transportation. We thank Jeff Speakman and Jim Cogswell for carrying out most of the lab work on this project. 


\section{References Cited}

Baxter, M. J.

1994 Stepwise discriminant analysis in archaeometry: a critique. Journal of Archaeological Science 21:659-666.

Bieber, A. M. Jr., D. W. Brooks, G. Harbottle, and E. V. Sayre

1976 Application of multivariate techniques to analytical data on Aegean ceramics. Archaeometry 18:59-74.

Bishop, R. L., and H. Neff

1989 Compositional data analysis in archaeology. In Archaeological Chemistry IV, edited by R. O. Allen, pp. 576-586. Advances in Chemistry Series 220, American Chemical Society, Washington, D.C.

Bishop, R. L., R. L. Rands, and G. R. Holley

1982 Ceramic compositional analysis in archaeological perspective. In Advances in Archaeological Method and Theory, vol. 5, pp. 275-330. Academic Press, New York.

Cogswell, J. W., H. Neff, and M. D. Glascock

1998 Analysis of shell-tempered pottery replicates: implications for provenance studies. American Antiquity 63:63-72.

Glascock, M. D.

1992 Characterization of archaeological ceramics at MURR by neutron activation analysis and multivariate statistics. In Chemical Characterization of Ceramic Pastes in Archaeology, edited by H. Neff, pp. 1126. Prehistory Press, Madison, Wisconsin.

Harbottle, G.

1976 Activation analysis in archaeology. Radiochemistry 3:33-72. The Chemical Society, London.

Leese, M. N., and P. L. Main

1994 The efficient computation of unbiased Mahalanobis distances and their interpretation in archaeometry. Archaeometry 36:307-316.

Neff, H.

1992 Introduction. In Chemical Characterization of Ceramic Pastes in Archaeology, edited by H. Neff, pp. 1-10. Prehistory Press, Madison, Wisconsin.

Sayre, E. V.

1975 Brookhaven Procedures for Statistical Analyses of Multivariate Archaeometric Data. Brookhaven National Laboratory Report BNL-23128. New York.

Steponaitis, V., M. J. Blackman, and H. Neff

1996 Large-scale compositional patterns in the chemical composition of Mississippian pottery. American Antiquity 61:555-572.

Weigand, P. C., G. Harbottle, and E. V. Sayre

1977 Turquoise sources and source analysis: Mesoamerica and the southwestern U.S.A. In Exchange Systems in Prehistory, edited by T. K. Earle and J. E. Ericson, pp. 15-34. Academic Press, New York. 



\section{Appendix VI \\ Petrographic Analysis of Bone Tempered Ceramics}




\title{
Appendix VI: Petrographic Analysis of Bone Tempered Ceramics
}

\author{
David V. Hill
}

\section{Introduction}

A sample of 21 ceramic sherds from site 41KA26-B located in south Texas were examined through petrographic analysis. Several compositional groups were identified based on the variation in the relative amount of sand and bone present in the sherds. A few ceramics were examined that contained minerals that are unavailable on the Texas Gulf coast. It is likely that these minerals represent items of trade.

\section{Methodology}

The ceramics were analyzed by the author using a Nikon Optiphot-2 petrographic microscope. The sizes of natural inclusions and tempering agents were described in terms of the Wentworth Scale, a standard method for characterizing particle sizes in sedimentology. These sizes were derived from measuring a series of grains using a graduated reticle built into one of the microscopes optics. The percentages of inclusions in untempered ceramics were estimated using comparative charts (Matthew et al. 1991; Terry and Chilingar 1955). Studies have been conducted regarding the reproducibility of determinations using these charts (Mason 1995). Given the limited amount of inclusions that may be present in ceramics and the small size of many of the sherds in the sample, the comparative method for assessing the amount and size of materials found in ceramics has been found as useful for archaeological ceramic petrography as point counting (Mason 1995).

Analysis was conducted by first going through the total ceramic collection and generating a brief description of each of the sherds. A second phase created classification groups based on the similarity of the paste and temper between sherds. A third check of the ceramics was made to see if the analytical groups were internally homogeneous. This process also allowed for the examination of the variability within each grouping. Additional comments about the composition of individual sherds were made at this time.

\section{Analysis of the Ceramic Sample}

\section{Sample \#201}

The paste of this sherd is a light yellowish brown color. The paste contains about $7 \%$ rounded yellowish gray fragments of siltstone. In addition to about $3 \%$ silt-sized to fine quartz sands are also present. Trace amounts of potassium feldspar, plagioclase and microcline are also present. The paste also contains sparse fine brown biotite. Some of the biotite has altered to hematite and clay minerals.

\section{Sample \#202}

The paste of this sherd is dark brown color with a silty texture and opaque appearance. Sparse silt-sized to very fine quartz sands are present in the paste. Bone fragments present make up about $15 \%$ of the matrix. The bone fragments range in size from fine to coarse. The bone fragments are opaque gray and display calcite rhombs around their margins.

\section{Sample \#203}

The paste of this sherd is a light reddish brown color. The paste resembles Samples \#205 and \#211 in terms of the sandy paste and sparse amount of bone temper. The paste contains about $25 \%$ silt-sized to fine quartz dominated sand grains and about $3 \%$ fine to medium-sized bone fragments. The bone fragments are yellowish gray under plain polarized light.

\section{Sample \#204}

The paste of this sherd is a medium to dark brown color and has a finer-grained silty texture. A few fine quartz sand grains are present in the paste and make up less than $1 \%$ of the ceramic matrix. Bone fragments make up about $15 \%$ of the ceramic matrix and range from coarse to fine in size. The bone fragments are dark brown to black in cross polarized light. 


\section{Sample \#205}

The paste of this sherd is a light reddish brown color. The composition of the inclusions closely resembles that of Sample \#211. The paste contains about $25 \%$ silt-sized to fine sand grains predominately quartz. Fine to medium-sized bone fragments make up only about $3 \%$ of the ceramic matrix. The bone fragments are yellowish gray under plain polarized light.

\section{Sample \#206}

The paste of this sherd is a dark brown color. It contains isolated mineral grains and rock fragments that were derived from a plutonic source. The mineral grains and rock fragments range continuously from silt-sized to coarse. These mineral grains appear to represent natural inclusions in the ceramic body. The mineral grains and rock fragments make up about $35 \%$ of the ceramic matrix. No bone was observed in the paste of this sherd.

The coarse rock fragments appear to have been derived from a granite. The rock fragments consist of potassium feldspar, plagioclase and quartz. The potassium feldspar in the rock fragments and isolated grains display alteration to sericite and clay minerals. Sparse pyroxene and brown biotite ware also present. The brown biotite was often altered to hematite and clay minerals. The continuous size distribution of the mineral grains and the degree of weathering of the feldspars indicated that the mineral inclusions in this ceramic are likely natural inclusions within the clay used in forming the ceramic.

\section{Sample \#207}

The paste of this sherd is a medium brown color mottled with dark brown, and it has a silty texture. Silt-sized to very fine quartz sand is present, but makes up less than $1 \%$ of the ceramic matrix. Fine to coarse-sized bone temper makes up about $15 \%$ of the ceramic matrix. The paste of this sherd resembles that of Samples \#212, \#219, and \#208. The bone fragments are brown and surrounded by calcite rhombs.

\section{Sample \#208}

The paste of this sherd is a medium brown color, and it has a silty texture. Silt-sized to very fine quartz sand is present, but makes up less than $1 \%$ of the ceramic matrix. Fine to coarse-sized bone temper makes up about $15 \%$ of the ceramic matrix. The bone fragments are yellowish gray under plain polarized light.

\section{Sample \#209}

The paste of this sherd is medium brown color and slightly birefringent. The paste also has a silty texture. Silt-sized to very fine quartz sand is present, but makes up less than $1 \%$ of the ceramic matrix. Fine to coarse-sized bone temper makes up about $15 \%$ of the ceramic matrix. The paste of this sherd resembles that of Samples \#212, \#219, \#208, \#207, and \#217. The bone fragments are yellowish gray under plain polarized light.

\section{Sample \#210}

The paste of this sherd is a dark brown and has a silty texture. Silt-sized to very fine quartz sand is present, but makes up less than $1 \%$ of the ceramic matrix. Fine to coarse-sized bone temper makes up about $15 \%$ of the ceramic matrix. The paste of this sherd resembles that of Samples \#212, \#219, \#208, \#207, \#209, and \#217. The bone fragments are yellowish gray under plain polarized light. Rims of calcite rhombs surround the particles of bone.

\section{Sample \#211}

The paste of this sherd is a light yellowish brown color and has a distinctive sandy texture resulting from the presence of $25 \%$ silt-sized to fine sub-rounded sand grains. Quartz makes up about $80 \%$ of the sand grains. Some of the quartz grains display undulatory extinction. Also present are potassium feldspar grains. Most of these grains display alteration to sericite and clay minerals. Bone fragments are present in the paste as well. Bone makes up only about $3 \%$ of the ceramic matrix. The bone fragments range in size from fine to medium. The bone is gray to white in color. 


\section{Sample \#212}

The paste of this sherd is medium mottled with a dark brown color, and a silty texture. Silt-sized to very fine quartz sand is present but makes up less than $1 \%$ of the ceramic matrix. Bone temper supplies about $15 \%$ of the ceramic matrix. The paste of this sherd resembles Sample \#214. The bone fragments are yellowish gray under plain polarized light. Calcite rhombs surround the bone fragments in the ceramic matrix.

\section{Sample \#213}

The paste of this sherd is a very dark brown and almost opaque. The paste contains about $35 \%$ rock fragments derived from a weathered granitic outcrop. The granite in the paste has a very similar composition to that of Sample \#206. The mineral grains consist of potassium feldspar, plagioclase and quartz. The feldspars are often altered to sericite and clay minerals.

\section{Sample \#214}

The paste of this sherd is a medium brown color with a distinctive silty texture. Very-fine-sized quartz sand is present, but makes up less than $1 \%$ of the ceramic matrix. Bone fragments that range from fine to coarse make up $15 \%$ of the ceramic body. The bone fragments are translucent under cross polarized light. Calcite rhombs surround the bone fragments.

\section{Sample \#215}

The paste of this sherd is a medium brown color with a distinctive silty texture. Silt-sized to very fine quartz sand is present, but makes up less than $1 \%$ of the ceramic matrix. Fine to very coarse-sized bone temper makes up about $20 \%$ of the ceramic matrix. The paste of this sherd resembles that of Samples \#212, \#219, \#208, $\# 207$, and \#217.

\section{Sample \#216}

The paste of this sherd is a medium to dark brown color. It contains $15 \%$ sub-rounded sands ranging from silt-sized to fine. A very coarse arkose with an opaque cement was also present.
Bone fragments were present, but made up only about $1 \%$ of the ceramic matrix. The bone fragments ranged from medium-sized to coarse. The bone fragments are yellow brown with gray cores under cross polarized light.

\section{Sample \#217}

The paste of this sherd is a dark brown color with a silty texture. Silt-sized to very fine quartz sand is present, but makes up less than $1 \%$ of the ceramic matrix. Fine to coarse-sized bone temper makes up about $15 \%$ of the ceramic matrix. The bone fragments are yellowish gray under plain polarized light.

\section{Sample \#218}

The paste of this sherd is a light reddish brown color. The paste resembles Samples \#205, \#211, and \#212 in terms of the sandy paste and sparse amount of bone temper. The paste contains about $25 \%$ silt-sized to fine quartz dominated sand grains and about $3 \%$ fine to medium-sized bone fragments. A single medium-sized rounded dark brown soil pisolite was also present in the matrix of the sherd. The bone fragments are yellowish gray under plain polarized light.

\section{Sample \#219}

The paste of this sherd is a medium brown color mottled with dark brown with a silty texture. Silt-sized to very fine quartz sand is present, but makes up less than $1 \%$ of the ceramic matrix. Fine to coarse-sized bone temper makes up about $15 \%$ of the ceramic matrix. The paste of this sherd resembles that of Sample \#212. The bone fragments are yellowish gray under plain polarized light.

\section{Sample \#220}

The paste of this sherd is a medium brown color with a fine-grained silty texture. Very fine quartz sands are present but make up less than $1 \%$ of the matrix. Bone fragments make up about 15\% of the matrix of the sherd. The bone fragments are poorly sorted ranging in size from coarse to fine. These bone fragments are translucent with gray cores under cross polarized light. 


\section{Sample \#221}

The paste of this sherd is a dark brown color with a silty texture. Silt-sized to very fine quartz sand is present, but makes up less than $1 \%$ of the ceramic matrix. Fine to coarse-sized bone temper makes up about $15 \%$ of the ceramic matrix. The paste of this sherd resembles that of Samples \#212, \#219, \#208 and \#207. The bone is a dark brown and slightly birefringent.

\section{Discussion and Conclusions}

Four compositional groups (Classes 2A, 2, 1, and 0) were identified primarily by the amount of bone relative to the amount of sand present in the sherds.
Class numbers rank relative amounts of bone in declining order. Sand represents a natural constituent of the sources of clay used in making all of the ceramics examined during the project. Bone represents an added material to the ceramic body.

\section{Class 2A}

The most commonly observed paste group in this small sample was distinguished by the limited amount of sand in the ceramic body. Nine sherds also had a limited amount of sand present in their paste. These sherds also had abundant bone temper. The bone in the case of these sherds was rimmed with calcite rhombs. Calcite was also present as a defining feature in the bone fragments. These sherds are listed as Class $2 \mathrm{~A}$ in Table VI-1.

Table VI-1. Petrographic Analysis of Bone Tempered Ceramics from 41KA26-B

\begin{tabular}{|c|c|c|c|c|c|c|}
\hline Sample \# & Provenience & Sand Size & Sand $\%$ & Bone Size & Bone $\%$ & Class \\
\hline 201 & $52-E$ & $\mathrm{~F}$ & 3 & 0 & 0 & 0 \\
\hline 202 & $52-E$ & St-VF & 1 & F-C & 15 & $2 \mathrm{~A}$ \\
\hline 203 & $29-B$ & St-F & 25 & F-M & 3 & 1 \\
\hline 204 & $29-E$ & $\mathrm{~F}$ & 1 & $\mathrm{~F}-\mathrm{C}$ & 15 & $2 \mathrm{~A}$ \\
\hline 205 & $13-\mathrm{D}$ & St-F & 25 & F-M & 3 & 1 \\
\hline 206 & $13-\mathrm{D}$ & St-C & 35 & 0 & 0 & 0 \\
\hline 207 & $13-\mathrm{D}$ & St-VF & 1 & $\mathrm{~F}-\mathrm{C}$ & 15 & $2 \mathrm{~A}$ \\
\hline 208 & $31-\mathrm{D}$ & St-VF & 1 & F-C & 15 & 2 \\
\hline 209 & $51-\mathrm{C}$ & St-VF & 1 & F-C & 15 & 2 \\
\hline 210 & $43-F$ & St-VF & 1 & F-C & 15 & $2 \mathrm{~A}$ \\
\hline 211 & $5-3$ & St-F & 25 & F-M & 3 & 1 \\
\hline 212 & $50-C$ & St-VF & 1 & $\mathrm{~F}-\mathrm{C}$ & 15 & $2 \mathrm{~A}$ \\
\hline 213 & $14-\mathrm{D}$ & St-C & 35 & 0 & 0 & 0 \\
\hline 214 & $3 B-B$ & VF & 1 & F-C & 15 & $2 \mathrm{~A}$ \\
\hline 215 & $57-C$ & St-VF & 1 & F-C & 20 & $2 \mathrm{~A}$ \\
\hline 16 & $56-E$ & St-F & 15 & M-C & 1 & 1 \\
\hline 217 & $47-B$ & St-VF & 1 & $\mathrm{FC}$ & 15 & $2 \mathrm{~A}$ \\
\hline 218 & $47-B$ & St-F & 25 & F-M & 3 & 1 \\
\hline 219 & $47-B$ & ST-VF & 1 & F-C & 15 & 2 \\
\hline 220 & $44-C$ & VF & 1 & F-C & 15 & 2 \\
\hline 221 & $35-C$ & St-VF & 1 & F-C & 15 & 2 \\
\hline
\end{tabular}




\section{Class 2}

Five sherds contained only a very limited amount of quartz sand. These sherds are listed as Class 2 in Table VI-1. These sherds also contained $15 \%$ bone temper. The paste of these sherds was a dark brown and the bone fragments were a dark brown color and often slightly birefringent.

\section{Class 1}

Another five sherds contained $15 \%$ to $25 \%$ silt-sized to fine sands, usually with a potassium feldspar component. These are listed as Class 1 in Table VI-1. These sands are likely to represent natural inclusions in the ceramic clay. The percentage of bone temper is low, $10 \%$ or less. The paste color is variable.

Sands present in sherds examined during the current project represent natural inclusions present in the source of the ceramic clay. The bone fragments are an added aplastic selected to control shrinkage of the ceramic clay. The amount of bone varies inversely to the amount of sand present in the ceramic paste. If a ceramic body has a sandy paste, then little bone will be present. Conversely ceramics containing a sparse amount of sand will contain a greater percentage of bone temper. This patterned variation within the sand and bone fragments demonstrates the knowledge that native potters had regarding the properties of the clays they used in producing their ceramics.

\section{Class 0}

Samples \#206 and \#213 contain sediments that were derived from a granitic source. The degree of weathering exhibited by the feldspars and continuous size distribution of the mineral grains and rock fragments indicates that the mineral grains in the paste of these sherds are natural inclusions, rather than an added temper. As granite is not available in south Texas, these sherds represent items of trade. These sherds are listed as Class 0 in Table VI-1.

Also in Class 0, Sample \#201 lacks additional bone temper. The paste of this sherd is a light yellowish brown color and contains sparse medium to coarse light yellowish gray siltstone grains and about 3\% silt-sized to fine quartz sands. It is possible that this sherd represents variability within the regional ceramic industry.

\section{References Cited}

Mason, R. B.

1995 Criteria for the Petrographic Characterization of Stonepaste Ceramics. Archaeometry 37(2):307-321.

Matthew, A. J., A. J. Woods, and C. Oliver

1991 Spots before the eyes: New comparison charts for visual percentage estimation in archaeological material. In Recent Developments in Ceramic Petrology, edited by A. Middleton and I. Freestone, pp. 211-264. British Museum Occasional Paper No. 81. British Museum Research Laboratory, London.

Terry, R. D., and V. G. Chilingar

1955 Summery of "Concerning some additional aids in studying sedimentary formations," by M. S. Shvetsov. Journal of Sedimentary Petrology 25:229-234. 


\section{Appendix VII: \\ 41KA26-B List of Proveniences Containing Faunal Material}


Appendix VII: 41KA26-B List of Proveniences Containing Faunal Material

\begin{tabular}{|c|c|c|c|c|c|c|c|c|c|c|c|c|c|c|}
\hline \multirow[t]{3}{*}{ ST\# } & $2-5$ & 1-D & $11 \mathrm{C}$ & & & & & & & & & & & \\
\hline & $2-6$ & & 11D & & & & & & & & & & & \\
\hline & & & $11 \mathrm{E}$ & & & & & & & & & & & \\
\hline \multicolumn{15}{|l|}{ Units } \\
\hline & & 3B-A & & $6 \mathrm{~A}$ & & & & & & & & & & \\
\hline & $3 \mathrm{~B}$ & 3B-B & & & & & & & & 13B & & & $16 \mathrm{~B}$ & \\
\hline & $3 \mathrm{C}$ & $3 \mathrm{~B}-\mathrm{C}$ & $4 \mathrm{C}$ & & & & & & & $13 \mathrm{C}$ & $14 \mathrm{C}$ & $15 \mathrm{C}$ & & \\
\hline \multirow[t]{8}{*}{$2 \mathrm{D}$} & $3 \mathrm{D}$ & 3B-D & & & & $8 \mathrm{D}$ & & $11 \mathrm{D}$ & $12 \mathrm{D}$ & 13D & $14 \mathrm{D}$ & $15 \mathrm{D}$ & & 17D \\
\hline & $3 \mathrm{E}$ & 3B-E & & $6 \mathrm{E}$ & & & & & & $13 \mathrm{E}$ & $14 \mathrm{E}$ & $15 \mathrm{E}$ & & $17 \mathrm{E}$ \\
\hline & & & & & $7 \mathrm{~F}$ & & $10 \mathrm{~F}$ & $11 \mathrm{~F}$ & $12 \mathrm{~F}$ & $13 \mathrm{~F}$ & & $15 \mathrm{~F}$ & & \\
\hline & & & & & $7 \mathrm{G}$ & & $10 \mathrm{G}$ & & & $13 \mathrm{G}$ & & $15 \mathrm{G}$ & & \\
\hline & & & & & & & & & & & & $15 \mathrm{H}$ & & \\
\hline & & $20 \mathrm{~A}$ & & & & $24 \mathrm{~A}$ & $25 \mathrm{~A}$ & $26 \mathrm{~A}$ & $27 \mathrm{~A}$ & $28 \mathrm{~A}$ & $29 \mathrm{~A}$ & $30 \mathrm{~A}$ & & \\
\hline & $19 \mathrm{~B}$ & $20 \mathrm{~B}$ & & $22 \mathrm{~B}$ & 23B & $24 \mathrm{~B}$ & & $26 \mathrm{~B}$ & & $28 \mathrm{~B}$ & $29 \mathrm{~B}$ & & & $32 \mathrm{~B}$ \\
\hline & $19 \mathrm{C}$ & $20 \mathrm{C}$ & & $22 \mathrm{C}$ & $23 \mathrm{C}$ & $24 \mathrm{C}$ & $25 \mathrm{D}$ & $26 \mathrm{C}$ & $27 \mathrm{C}$ & $28 \mathrm{C}$ & $29 \mathrm{C}$ & $30 \mathrm{C}$ & & $32 \mathrm{C}$ \\
\hline $18 \mathrm{D}$ & & $20 \mathrm{D}$ & 21D & $22 \mathrm{D}$ & $23 \mathrm{D}$ & $24 \mathrm{D}$ & & $26 \mathrm{D}$ & & & 29D & $30 \mathrm{D}$ & 31D & $32 \mathrm{D}$ \\
\hline $18 \mathrm{E}$ & $19 \mathrm{E}$ & & $21 \mathrm{E}$ & $22 \mathrm{E}$ & $23 \mathrm{E}$ & $24 \mathrm{E}$ & & & & & $29 \mathrm{E}$ & $30 \mathrm{E}$ & $31 \mathrm{E}$ & $32 \mathrm{E}$ \\
\hline $18 \mathrm{~F}-3$ & & & & & & & & & & & & $30 \mathrm{~F}$ & & \\
\hline $33 \mathrm{~A}$ & $34 \mathrm{~A}$ & $35 \mathrm{~A}$ & & $37 \mathrm{~A}$ & & $40 \mathrm{~A}$ & & & & & & & $47 \mathrm{~A}$ & \\
\hline \multirow[t]{2}{*}{$33 \mathrm{~B}$} & & $35 \mathrm{~B}$ & & 37B & $38 \mathrm{~B}$ & $40 \mathrm{~B}$ & & $42 \mathrm{~B}$ & & & 45B & $46 \mathrm{~B}$ & $47 \mathrm{~B}$ & $48 \mathrm{~B}$ \\
\hline & & & $36 \mathrm{C}$ & $37 \mathrm{C}$ & $38 \mathrm{C}$ & $40 \mathrm{C}$ & $41 \mathrm{C}$ & $42 \mathrm{C}$ & $43 \mathrm{C}$ & $44 \mathrm{C}$ & $45 \mathrm{C}$ & $46 \mathrm{C}$ & $47 \mathrm{C}$ & $48 \mathrm{C}$ \\
\hline \multirow[t]{8}{*}{ 33D } & $34 \mathrm{D}$ & $35 \mathrm{D}$ & $36 \mathrm{D}$ & & & & 41D & $42 \mathrm{D}$ & 43D & $44 \mathrm{D}$ & 45D & $46 \mathrm{D}$ & 47D & $88 \mathrm{D}$ \\
\hline & & $35 \mathrm{E}$ & $36 \mathrm{E}$ & & & & & & $43 \mathrm{E}$ & & $45 \mathrm{E}$ & $46 \mathrm{E}$ & $47 \mathrm{E}$ & \\
\hline & & & & & & & & & $43 \mathrm{~F}$ & & & $46 \mathrm{~F}$ & $47 \mathrm{~F}$ & \\
\hline & & & & & & & & & $43 \mathrm{G}$ & & & & & \\
\hline & & & & & & & & & $43 \mathrm{H}$ & & & & & \\
\hline & & & & & & & & & $43 \mathrm{I}$ & & & & & \\
\hline & & & & & & & & & $43 \mathrm{~J}$ & & & & & \\
\hline & & & & & & & & & $43 \mathrm{~K}$ & & & & & \\
\hline \multicolumn{15}{|l|}{$49 \mathrm{~A}$} \\
\hline $49 \mathrm{~B}$ & $50 \mathrm{~B}$ & & $52 \mathrm{~B}$ & & & & & & $57 \mathrm{~B}$ & & & & & \\
\hline $49 \mathrm{C}$ & & $51 \mathrm{C}$ & & & $53 \mathrm{C}$ & & & $56 \mathrm{C}$ & $57 \mathrm{C}$ & & & & & \\
\hline 49D & & 51D & & $52 \mathrm{~A}-\mathrm{D}$ & $53 \mathrm{D}$ & $54 \mathrm{D}$ & $55 \mathrm{D}$ & $56 \mathrm{D}$ & & & & & & \\
\hline \multirow[t]{4}{*}{$49 \mathrm{E}$} & $50 \mathrm{E}$ & & $52 \mathrm{E}$ & $52 \mathrm{~A}-\mathrm{E}$ & & $54 \mathrm{E}$ & $55 \mathrm{E}$ & & & & & & & \\
\hline & $50 \mathrm{~F}$ & & & & & $54 \mathrm{~F}$ & & & & & & & & \\
\hline & $50 \mathrm{G}$ & & & & & $54 \mathrm{G}$ & & & & & & & & \\
\hline & $50 \mathrm{H}$ & & & & & & & & & & & & & \\
\hline
\end{tabular}


Appendix VIII:

41KA26-B Bone Measurements 
Appendix VIII: 41KA26-B Bone Measurements

\begin{tabular}{|c|c|c|c|c|c|c|c|}
\hline Taxon & Element & Dimension & $\mathbf{m m}$ & Taxon & Element & Dimension & $\mathbf{m m}$ \\
\hline G. gallus & femur & $\mathrm{SC}$ & 6.5 & O. virginianus & phalanx 2 & $\mathrm{Bp}$ & 11.64 \\
\hline G. gallus & humerus & $\mathrm{SC}$ & 5.88 & O. virginianus & phalanx 2 & GL & 29.39 \\
\hline G. gallus & humerus & $\mathrm{Bp}$ & 19.33 & O. virginianus & phalanx 2 & $\mathrm{GL}$ & 29.74 \\
\hline G. gallus & ulna & GL & 69.06 & O. virginianus & phalanx 2 & SD & 8.58 \\
\hline G. gallus & ulna & Dip & 8.51 & O. virginianus & phalanx 2 & $\mathrm{SD}$ & 8.69 \\
\hline G. gallus & ulna & $\mathrm{Bp}$ & 8 & O. virginianus & phalanx 3 & DLS & 29.07 \\
\hline G. gallus & ulna & $\mathrm{SC}$ & 4.31 & O. virginianus & phalanx 3 & DLS & 29.44 \\
\hline G. gallus & ulna & Did & 8.92 & O. virginianus & phalanx 3 & DLS & 29.88 \\
\hline G. gallus & carpometacarpus & Did & 6.85 & O. virginianus & phalanx 3 & $\mathrm{Ld}$ & 26.37 \\
\hline M. gallopavo & tarsometatarsus & GL & 131.01 & O. virginianus & phalanx 3 & $\mathrm{Ld}$ & 26.41 \\
\hline M. gallopavo & tarsometatarsus & Bp & 20.06 & O. virginianus & phalanx 3 & $\mathrm{Ld}$ & 27.7 \\
\hline M. gallopavo & tarsometatarsus & $\mathrm{SC}$ & 8.67 & O. virginianus & phalanx 3 & MBS & 6.8 \\
\hline M. gallopavo & tibiotarsus & $\mathrm{SC}$ & 10.76 & O. virginianus & phalanx 3 & MBS & 6.88 \\
\hline O. virginianus & cubonavicular & GB & 27.25 & O. virginianus & phalanx 3 & MBS & 7.29 \\
\hline O. virginianus & femur & $\mathrm{Bd}$ & 44.94 & O. virginianus & radius & $\mathrm{BP}$ & 32.08 \\
\hline O. virginianus & malleolaire & GD & 16.97 & O. virginianus & radius & BFp & 30.92 \\
\hline O. virginianus & metacarpal & $\mathrm{DD}$ & 11.27 & O. virginianus & ulnar carpal & GB & 22.35 \\
\hline O. virginianus & metacarpal & $\mathrm{Bd}$ & 26.64 & Bos sp. & metatarsal & $\mathrm{SD}$ & 27.6 \\
\hline O. virginianus & metacarpal & $\mathrm{Dd}$ & 18.64 & Bos sp. & tibia & $\mathrm{SD}$ & 31.86 \\
\hline O. virginianus & phalanx 1 & $\mathrm{Bd}$ & 10.27 & Bos sp. & phalanx 1 & $\mathrm{SD}$ & 23.62 \\
\hline O. virginianus & phalanx 1 & $\mathrm{Bd}$ & 10.42 & Bos sp. & cubonavicular & GB & 60.16 \\
\hline O. virginianus & phalanx 1 & $\mathrm{Bp}$ & 12.49 & Bos sp. & cubonavicular & GB & 51.68 \\
\hline O. virginianus & phalanx 1 & $\mathrm{Bp}$ & 12.91 & cf. Bos bison & astragalus & $\mathrm{Bd}$ & 42.81 \\
\hline O. virginianus & phalanx 1 & GLpe & 38.7 & cf. Bos bison & astragalus & $\mathrm{Dl}$ & 38.07 \\
\hline O. virginianus & phalanx 1 & GLpe & 39.88 & cf. Bos bison & astragalus & $\mathrm{Dm}$ & 36.04 \\
\hline O. virginianus & phalanx 1 & $\mathrm{SD}$ & 8.6 & cf. Bos bison & astragalus & GL1 & 67.35 \\
\hline O. virginianus & phalanx 1 & $\mathrm{SD}$ & 8.69 & cf. Bos bison & astragalus & GLm & 62.84 \\
\hline O. virginianus & phalanx 1 & $\mathrm{SD}$ & 9.32 & cf. Bos bison & calcaneus & GB & 43.17 \\
\hline O. virginianus & phalanx 2 & $\mathrm{Bd}$ & 8.98 & cf. Bos bison & calcaneus & GL & 137.3 \\
\hline O. virginianus & phalanx 2 & $\mathrm{Bd}$ & 9.08 & cf. Bos bison & metatarsus & $\mathrm{Bd}$ & 55.79 \\
\hline O. virginianus & phalanx 2 & $\mathrm{Bd}$ & 9.36 & cf. Bos bison & metatarsus & $\mathrm{Bp}$ & 46.17 \\
\hline O. virginianus & phalanx 2 & $\mathrm{Bp}$ & 11.45 & cf. Bos bison & metatarsus & $\mathrm{DD}$ & 24.13 \\
\hline cf. Bos bison & metatarsus & $\mathrm{Dd}$ & 32.07 & cf. Bos bison & ulna & $\mathrm{BPC}$ & 41.66 \\
\hline cf. Bos bison & metatarsus & GL & 233 & cf. Bos bison & ulna & DPA & 70.19 \\
\hline cf. Bos bison & metatarsus & $\mathrm{SD}$ & 26.96 & cf. Bos bison & ulna & $\mathrm{LO}$ & 98.74 \\
\hline cf. Bos bison & phalanx 1 & $\mathrm{Bd}$ & 27.59 & cf. Bos bison & ulna & $\mathrm{SDO}$ & 52.02 \\
\hline cf. Bos bison & phalanx 1 & Glpe & 58.87 & cf. Bos taurus & phalanx 2 & $\mathrm{Bd}$ & 24.92 \\
\hline cf. Bos bison & phalanx 1 & $\mathrm{SD}$ & 24.88 & cf. Bos taurus & phalanx 2 & $\mathrm{Bd}$ & 26.42 \\
\hline cf. Bos bison & phalanx 2 & GL & 39.05 & cf. Bos taurus & phalanx 2 & $\mathrm{Bp}$ & 30.22 \\
\hline cf. Bos bison & phalanx 2 & $\mathrm{Bd}$ & 22.92 & cf. Bos taurus & phalanx 2 & $\mathrm{Bp}$ & 31.43 \\
\hline cf. Bos bison & phalanx 2 & $\mathrm{Bp}$ & 29.09 & cf. Bos taurus & phalanx 2 & $\mathrm{GL}$ & 38.49 \\
\hline cf. Bos bison & phalanx 2 & $\mathrm{SD}$ & 20.25 & cf. Bos taurus & phalanx 2 & GL & 43.96 \\
\hline cf. Bos bison & tibia & $\mathrm{Bd}$ & 60.95 & cf. Bos taurus & phalanx 2 & $\mathrm{SD}$ & 24.16 \\
\hline cf. Bos bison & tibia & $\mathrm{Bp}$ & 92.61 & cf. Bos taurus & phalanx 2 & $\mathrm{SD}$ & 24.91 \\
\hline cf. Bos bison & tibia & $\mathrm{Dd}$ & 42.82 & cf. Bos taurus & phalanx 1 & $\mathrm{Bd}$ & 26.88 \\
\hline cf. Bos bison & tibia & GL & 343.5 & cf. Bos taurus & phalanx 1 & $\mathrm{Bp}$ & 27.77 \\
\hline cf. Bos bison & tibia & LI & 308 & cf. Bos taurus & phalanx 1 & GLpe & 61.79 \\
\hline cf. Bos bison & tibia & SD & 39.72 & cf. Bos taurus & phalanx 1 & $\mathrm{SD}$ & 24.42 \\
\hline
\end{tabular}



The information is provided in accordance with the General Rules of Practice and Procedure, Chapter 41.11 (Investigative Reports), Texas Antiquities Committee:

1. Type of investigation: Data recovery and mitigation

2. Project name: KA26, Karnes, Texas

3. County: Karnes

4. Principal investigators: Robert J. Hard and Cynthia L. Tennis

5. Name and location of sponsoring agency: Texas Department of Transportation, Austin, Texas 78701-2483

6. Texas Antiquities Permit No.: 492

7. Published by the Center for Archaeological Research, The University of Texas at San Antonio, 6900 N. Loop 1604 W., San Antonio, Texas 78249-0658, 2001

A list of publications offered by the Center for Archaeological Research is available. Call (210) 458-4378; write to the Center for Archaeological Research, The University of Texas at San Antonio, 6900 N. Loop 1604 W., San Antonio, Texas 78249-0658; e-mail to car@lonestar.utsa.edu; or visit CAR's web site at http://car.utsa.edu. 